STUDI KERAGAMAN DAN FUNGSI EKOLOGIS POHON PADA LANSKAP PERKAMPUNGAN BUDAYA BETAWI SETU BABAKAN, SRENGSENG SAWAH, JAGAKARSA, JAKARTA SELATAN

WIDYASTUTI UTAMI

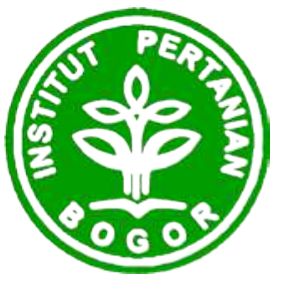

DEPARTEMEN ARSITEKTUR LANSKAP

FAKULTAS PERTANIAN

INSTITUT PERTANIAN BOGOR

2013 


\section{RINGKASAN}

WIDYASTUTI UTAMI. Studi Keragaman dan Fungsi Ekologis Pohon pada Lanskap Perkampungan Budaya Betawi Setu Babakan, Srengseng Sawah, Jagakarsa, Jakarta Selatan

Perkampungan Budaya Betawi Setu Babakan merupakan sebuah kawasan budaya di wilayah Jakarta Selatan yang masih dijaga nilai ekologisnya melalui keberadaan vegetasi, diresmikan pada tahun 2004 melalui SK Gubernur No. 9 Tahun 2000, sebagai sebuah kawasan Cagar Budaya. Kawasan ini terdiri dari sebuah area rekreasi danau seluas \pm 32 ha dan wisata agro sebagai bagian dari bentuk kegiatan pariwisata yang memanfaatkan usaha pertanian (agro) pada pekarangan rumah-rumah penduduk untuk objek wisata. Kawasan dengan luas ¥289 ha ini dikelilingi oleh empat kelurahan, yaitu Kelurahan Jagakarsa di bagian ütara, Kelurahan Kalisari di bagian timur, Kelurahan Srengsengsawah di bagian sëlatan, dan Kelurahan Ciganjur di bagian barat.

Penelitian difokuskan pada dua lokasi utama, yaitu area lingkar Setu Babakan dan pekarangan yang terdiri dari sepuluh pekarangan contoh yang berada đi dalam RT09 dan RT10/RW08. Penelitian dilaksanakan mulai dari bulan April hingga Agustus 2012. Tahapannya terdiri dari persiapan, inventarisasi, analisis, dan perumusan rekomendasi. Metode analisis dilakukan secara kuantitatif dan deskriptif untuk identifikasi jenis-jenis pohon, serta dilakukan pada dua aspek uttama lain penelitian, yaitu analisis untuk nilai keragaman pohon dan fungsi èkologis pohon pada area lingkar danau dan pekarangan. Identifikasi dilakukan untuk mengetahui keberadaan jenis-jenis pohon langka pada tapak dengan membandingkan vegetasi pohon eksisting terhadap jenis-jenis pohon langka yang terdaftar pada SK Gubernur DKI Jakarta Nomor: 2359/1987. Analisis untuk nilai keragaman pohon, dilakukan dengan cara identifikasi jenis terhadap masingmasing individu pohon, menghitung indeks keragaman pohon, dan menspasialkan sebaran pohon untuk mengetahui dominansi secara visual. Pada analisis terhadap fungsi ekologis, dilakukan melalui proses evaluasi terhadap kriteria melalui ciri morfologis tertentu untuk masing-masing fungsi pohon, membandingkan presentase kriteria secara deskriptif setelah dilakukan perhitungan, serta menspasialkannya untuk mengetahui sebaran di dalam mengetahui kesesuaian tingkat kenyamanan bagi pengguna.

Berdasarkan hasil analisis yang telah dilakukan terhadap jenis-jenis pohon pada area penelitian Perkampungan Budaya Betawi Setu Babakan, terdapat 76 jenis pohon yang terdiri dari 44 jenis pohon (778 individu) pada area lingkar Setu Babakan dan 42 jenis pohon (112 individu) pada sepuluh pekarangan contoh. Berdasarkan SK Gubernur DKI Jakarta Nomor: 2359/1987, terdapat delapan jenis pohon langka yang ditemukan pada area lingkar Setu Babakan dan sepuluh pekarangan contoh. Pohon-pohon langka tersebut terdiri dari srikaya (Annona squamosa), buni (Antidesma bunius), bisbul (Diospyros blancoi), kawista batu (Feronia lucida), rukem (Flacourtia rukam), duku condet (Lansium domesticum), mengkudu (Morinda citrifolia), dan jamblang (Syzygium cumini). Jenis-jenis pohon pada area lingkar Setu Babakan cenderung tergolong jenis yang lebih memberikan fungsi ekologis untuk kenyamanan pengguna di dalam kawasan, 
sedangkan jenis-jenis pohon pada pekarangan secara mayoritas tergolong jenis yang memberikan fungsi produksi, seperti penghasil buah untuk konsumsi.

Keragaman pohon di dalam area lingkar Setu Babakan tergolong tinggi. Hal ini diperoleh melalui perhitungan nilai indeks keragaman dari rumus Shannon-Wiener, sebesar 4.24. Adapun untuk tapak berupa pekarangan, melalui rumus perhitungan sama diperolehlah nilai indeks keragaman untuk setiap masing-masing contoh. Pekarangan dengan indeks keragaman tertinggi hingga terendah, yaitu pekarangan $10(\mathrm{H}=3.38)$, pekarangan $6(\mathrm{H}=3.33)$, pekarangan 2 $(\mathrm{H}=3.09)$, pekarangan $3(\mathrm{H}=3.03)$, pekarangan $9(\mathrm{H}=2.75)$, pekarangan 5 $(\mathrm{H}=2.56)$, pekarangan $1(\mathrm{H}=2.32)$, pekarangan $7(\mathrm{H}=2.25)$, pekarangan 4 $(\mathrm{H}=2.00)$, hingga pekarangan $8(\mathrm{H}=1.69)$.

Berdasarkan hasil penilaian terhadap jenis-jenis pohon melalui lima aspek fungsi ekologis pada area lingkar Setu Babakan, diperolehlah persentase untuk masing-masing aspek yang terdiri dari kategori sangat baik (SB), baik (BA), kurang baik (KB), dan buruk (BU). Hasil tersebut meliputi: (1) fungsi ekologis üntuk modifikasi suhu sebagai penaung, SB: 22 jenis pohon (62.81\%), BA: 8 jenis pohon (21.62\%), KB: 12 jenis pohon (15.32\%), dan BU: 1 jenis pohon $(0.26 \%)$; (2) fungsi ekologis untuk kontrol kelembaban udara, BA: 2 jenis pohon (2.45\%), KB: 15 jenis pohon (29.99\%), dan BU: 26 jenis pohon (67.57\%); (3) fungsi ekologis peredam kebisingan, SB: 8 jenis (29.34\%), BA: 15 jenis pohon (34.11\%), KB: 15 jenis pohon (29.6\%), dan BU: 5 jenis pohon (6.95\%); (4) fungsi ekologis pohon penahan angin, SB: 16 jenis pohon (43.37\%), BA: 15 jenis pohon (39.90\%), KB: 11 jenis pohon (16.47\%), dan BU: 1 jenis pohon $(0.26 \%)$; (5) fungsi ekologis pohon untuk menghadirkan satwa (burung), SB: 24 jenis pohon (72.33\%), BA: 7 jenis pohon (15.83\%), KB: 9 jenis pohon (9.27\%), dan BU: 3 jenis pohon (2.57\%).

Pada sepuluh pekarangan contoh, melalui penilaian yang sama diperolehlah hasil sebagi berikut: (1) fungsi ekologis pohon untuk modifikasi suhu sebagai penaung, SB: 14 jenis pohon (26.79\%), BA: 5 jenis pohon (21.43\%), KB: 21 jenis pohon (50.00\%), dan BU: 2 jenis pohon (1.79\%); (2) fungsi ekologis untuk kontrol kelembaban udara, KB: 6 jenis pohon (15.18\%) dan BU: 36 jenis pohon (84.82\%); (3) fungsi ekologis pohon peredam kebisingan, SB: 17 jenis pohon (38.39\%), BA: 6 jenis pohon (14.29\%), KB: 16 jenis pohon (41.07\%), dan BU: 3 jenis pohon $(6.25 \%)$; (4) fungsi ekologis pohon penahan angin, SB: 19 jenis pohon (45.54\%), BA: 3 jenis pohon (5.36\%), KB: 17 jenis pohon (45.54\%), dan BU: 3 jenis pohon (3.57\%); (5) fungsi ekologis pohon untuk menghadirkan satwa (burung), SB: 34 jenis pohon (83.93\%), BA: 3 jenis pohon (4.46\%), dan KB: 5 jenis pohon (11.61\%).

Kata kunci: fungsi ekologis, nilai keragaman, pohon langka di Jakarta 
STUDI KERAGAMAN DAN FUNGSI EKOLOGIS POHON PADA

LANSKAP PERKAMPUNGAN BUDAYA BETAWI SETU BABAKAN, SRENGSENG SAWAH, JAGAKARSA, JAKARTA SELATAN

\title{
WIDYASTUTI UTAMI
}

Skripsi

sebagai salah satu syarat untuk memperoleh gelar

Sarjana Pertanian pada

Fakultas Pertanian Institut Pertanian Bogor

\author{
DEPARTEMEN ARSITEKTUR LANSKAP \\ FAKULTAS PERTANIAN \\ INSTITUT PERTANIAN BOGOR \\ 2013
}




\section{PERNYATAAN MENGENAI SKRIPSI DAN SUMBER INFORMASI}

Dengan ini, saya menyatakan bahwa skripsi yang berjudul "Pengaruh Komposisi Elemen-elemen Taman dan Kriteria Hemat Energi Terhadap Kualitas Estetika Visual” adalah benar merupakan hasil karya sendiri dan belum diajukan dalam bentuk apa pun kepada perguruan tinggi mana pun. Semua sumber data dan informasi baik yang berasal atau dikutip dari karya yang diterbitkan maupun yang tidak diterbitkan dari penulis lain, telah disebutkan dalam teks dan dicantumkan pada Daftar Pustaka skripsi ini.

Bogor, Februari 2013

Widyastuti Utami

A44080015 
Dilarang mengutip sebagian atau seluruh karya tulis ini tanpa mencantumkan atau menyebutkan sumbernya. Pengutipan hanya untuk kepentingan pendidikan, $\overrightarrow{p e n e l i t i a n, ~ p e n u l i s a n ~ k a r y a ~ i l m i a h, ~ p e n y u s u n a n ~ l a p o r a n, ~ p e n u l i s a n ~ k r i t i k, ~ a t a u ~}$ tinjauan suatu masalah; dan pengutipan tersebut tidak merugikan kepentingan yang wajar IPB. $\underline{0}$

Dilarang mengumumkan dan memperbanyak sebagian atau seluruh karya tulis ini dalam bentuk apa pun tanpa izin IPB. 


\section{LEMBAR PENGESAHAN}

Judul : Studi Keragaman dan Fungsi Ekologis Pohon pada

Lanskap Perkampungan Budaya Betawi Setu Babakan, Srengseng

Sawah, Jagakarsa, Jakarta Selatan

Nama : Widyastuti Utami

NRP : A44080015

D̄epartemen : Arsitektur Lanskap

Disetujui,

Dosen Pembimbing

Dr. Ir. Tati Budiarti, MS

NIP. 196107201984032002

Diketahui,

Ketua Departemen Arsitektur Lanskap

Dr. Ir. Siti Nurisjah, MSLA

NIP. 194809121974122001

Tanggal Lulus: 


\section{RIWAYAT HIDUP}

Penulis dilahirkan di Bogor pada tanggal 6 April 1990, sebagai seorang anak tunggal dari pasangan Bapak Herman Suherman (almarhum) dan Ibu Widadaning Binawarti. Pada tahun 1996, penulis lulus dari Sekolah Taman Kanak-Kanak Pakuan dan meneruskan studinya ke Sekolah Dasar Negeri Pakuan, lulus pada tahun 2002. Selanjutnya, pendidikan sekolah menengah ditempuh penulis di SMPN 1 Bogor yang dilanjutkan ke SMAN 1 Bogor, masingmăasing diselesaikan pada tahun 2005 dan 2008.

烈 Memasuki jenjang perkuliahan, penulis berhasil menjadi bagian dari salah satu mahasiswa Institut Pertanian Bogor pada tahun 2008 melalui jalur Undangan Selekesi Masuk IPB (USMI) ke dalam jurusan Arsitektur Lanskap. Organisasi yạng sempat diikuti oleh penulis antara lain Himpunan Mahasiswa Arsitektur Lanskap (HIMASKAP) pada Divisi Infos dan Koran Kampus IPB (Korpus IPB) șebagai Kartunis. Penulis juga pernah mengikuti sayembara yang berkaitan dengan bidang arsitektur lanskap, seperti Sayembara Desain Taman Topi (2010), Sayembara Perancangan Taman Komunitas Hijau Pondok Indah (2011), dan ÄECOM Urban SOS Student Competition (2012). 


\section{KATA PENGANTAR}

Puji dan syukur saya panjatkan atas kehadirat Allah swt, berkat rahmat-Nyalah, saya dapat merampungkan tugas akhir penelitian saya yang berjudul Studi Keragaman dan Fungsi Ekologis Pohon pada Lanskap Perkampungan Budaya Betawi Setu Babakan, Srengseng Sawah, Jagakarsa, Jakarta Selatan sebagai salah satu syarat untuk memperoleh gelar sarjana dari Departemen Arsitektur Lanskap, Fakultas Pertanian, Institut Pertanian Bogor. Penelitian yang berlokasi di Jakarta Selatan ini dikhususkan pada area lingkar danau dan sepuluh pekarangan contoh. Pada kesempatan ini penulis ingin menyampaikan terima kasih kepada

Dr. Ir. Tati Budiarti, MS selaku dosen pembimbing skripsi atas segala bimbingan, saran, serta motivasi selama masa penyelesaian tugas akhir

2. Dr. Ir. Nizar Nasrullah, M.Agr dan Dr. Ir. Bambang Sulistyantara atas saran dan bimbingannya untuk penulisan skripsi yang lebih baik

3. Bang Indra dan seluruh staf dari pengelola Perkampungan Budaya Betawi Setu Babakan atas informasi, arahan, dan bantuan selama proses penelitian

4. Ibu, Widadaning Binawarti dan keluarga atas dukungan baik moral, spiritual, dan material

5. Teman-teman Arsitektur Lanskap angkatan 45 atas semangat, keriangan, dan kebersamaannya selama ini

6. Desi Anjana, Enjoyment Akbar, dan Amelia Anggraini atas segala bantuannya selama penelitian dan informasi berharga dalam penulisan skripsi

7. Rheza Ardiansyah atas kebersamaannya dan semangat untuk tetap optimis di dalam menyelesaikan tugas dan meraih cita-cita

8. Seluruh pihak yang turut membantu dalam penulisan skripsi

(Besar harapan penulis agar skripsi ini dapat bermanfaat bagi area rekreasi Perkampungan Budaya Betawi Setu Babakan dan pihak yang memerlukannya.

Bogor, Februari 2013

Penulis 


\section{DAFTAR ISI}

DAFTAR TABEL ........................................................................ iv

DAFTAR GAMBAR …......................................................................

DAFTAR LAMPIRAN .................................................................. vi

I. PENDAHULUAN

T 1.1 Latar Belakang....................................................................... 1

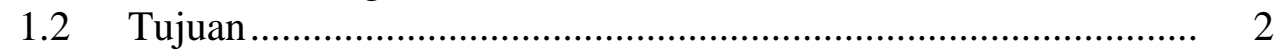

1.3 Kerangka Pikir..........................................................................

ㄹ. TINJAUAN PUSTAKA

$2.1 \quad$ Ekologi........................................................................ 5

2.2 Fungsi Ekologis Pohon .......................................................... 5

2.2.1 Modifikasi Suhu sebagai Penaung ................................ 6

2.2.2 Kontrol Kelembaban Udara ............................................ 6

2.2.3 Penahan Angin .......................................................... 7

2.2.4 Peredam Kebisingan...................................................... 8

2.2.5 Kehadiran Satwa (Burung)............................................. 9

2.3 Keragaman Pohon........................................................................ 13

2.4 Lanskap Budaya ................................................................. 14

2.5 Ruang Terbuka Hijau........................................................... 15

HI. METODOLOGI

3.1 Lokasi dan Waktu Penelitian ...................................................... 17

3.2 Bahan dan Alat ...................................................................... 18

Tahapan Penelitian
3.3.1 Persiapan .................................................................... 18

3.3.2 Inventarisasi ......................................................... 19

3.3.3 Analisis....................................................................... 20

3.3.3.1 Penilaian Tingkat Keragaman
Spesies Pohon

3.3.3.2 Penilaian Fungsi Ekologis Individu Pohon ........ 21

3.3.4 Rekomendasi....................................................... 22

IV. KONDISI UMUM

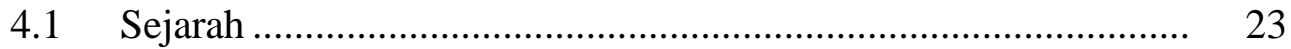

4.2 Letak, Luas, dan Aksesibilitas.................................................... 24

4.3 Klimatologi........................................................................ 26

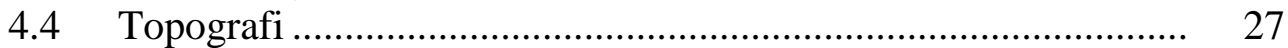

4.5 Kondisi Tanah............................................................... 27

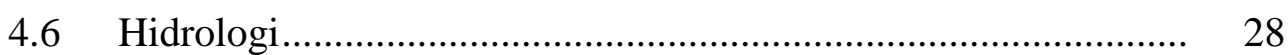

4.7 Vegetasi dan Satwa............................................................ 29

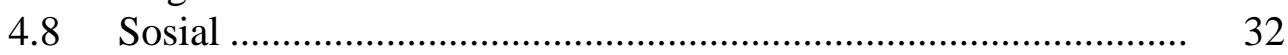

4.9 Tata Guna Lahan ................................................................... 35 
V. ANALISIS DATA DAN PEMBAHASAN

5.1 Identifikasi Karakteristik RTH Lanskap Setu Babakan ............... 37

5.2 Pengaruh Sosial terhadap RTH Lanskap Setu Babakan ................. 38

$5.3 \quad$ Identifikasi Jenis Pohon pada Tapak ......................................... 39

5.4 Analisis Nilai Keragaman Pohon .............................................. 47

5.5 Analisis Fungsi Ekologis Pohon pada Area

Lingkar Setu Babakan ........................................................... 53

5.5.1 Modifikasi Suhu ............................................................. 53

5.5.2 Kontrol Kelembaban Udara .......................................... 59

5.5.3 Peredam Kebisingan ...................................................... 65

5.5.4 Penahan Angin ................................................................. $\quad 70$

5.5.5 Kehadiran Satwa (Burung)........................................... 74

5.6 Analisis Fungsi Ekologis Pohon pada Pekarangan...................... 80

5.6.1 Modifikasi Suhu ......................................................... 80

5.6.2 Kontrol Kelembaban Udara .......................................... 83

5.6.3 Peredam Kebisingan ................................................... 85

5.6.4 Penahan Angin ............................................................ 88

5.6.5 Kehadiran Satwa (Burung) ............................................ 90

VI. REKOMENDASI

6.1 Jenis-Jenis Pohon Langka pada Lanskap Area

Rekreasi Setu Babakan ............................................................. 94

6.2 Keragaman Pohon................................................................ 95

6.3 Fungsi Ekologis Pohon ...................................................... 97

VII.SIMPULAN DAN SARAN

7.1 Simpulan ......................................................................... 101

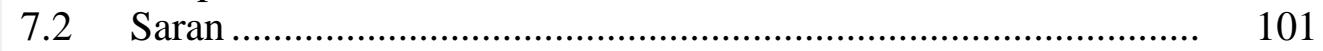

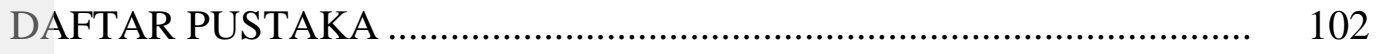

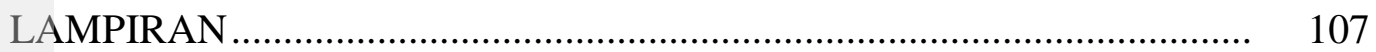




\section{DAFTAR TABEL}

No

Halaman

1. Daftar Jenis Vegetasi (Pohon dan Semak) untuk Burung...................... 10

2. Jenis Data Penelitian .......................................................................... 18

3. Jenis-Jenis Pohon Langka Jakarta ..................................................... 19

4. Variabel Fungsi Ekologis dan Kriteria Penilaian.................................... 21

5. Data Iklim Perkampungan Budaya Betawi Setu Babakan ..................... 26

6. Daftar Jenis Burung Di Kawasan Setu Babakan ..................................... 30

7. Burung dan Jenis Pohon yang Disukai ................................................. 30

8. Penggunaan Lahan Perkampungan Budaya Betawi Setu Babakan....................................................................................... 35

9. Daftar Jenis-Jenis Pohon Lingkar Setu dan Pekarangan........................ 39

10. Daftar Jumlah Pohon pada Lingkar Setu Babakan ................................ 47

11. Jenis-Jenis Pohon pada Pekarangan Contoh ........................................ 50

12. Kriteria Penilaian Aspek Fungsi Modifikasi Suhu sebagai Penaung..... 54

13. Kriteria Penilaian Aspek Fungsi Kontrol Kelembaban Udara................ 59

14. Kriteria Penilaian Aspek Fungsi Peredam Kebisingan .......................... 65

15. Kriteria Penilaian Aspek Fungsi Penahan Angin.................................... 70

16. Kriteria Penilaian Aspek Fungsi Menghadirkan Satwa (Burung) ......... 75

17. Kriteria Penilaian Aspek Fungsi Modifikasi Suhu (Pekarangan) ........... 80

18. Kriteria Penilaian Aspek Fungsi Kontrol Kelembaban Udara

(Pekarangan) ............................................................................ 83

19. Kriteria Penilaian Aspek Peredam Kebisingan (Pekarangan)................ 85

20. Kriteria Penilaian Aspek Penahan Angin (Pekarangan) ........................ 88

21. Kriteria Penilaian Aspek Menghadirkan Satwa (Burung)

(Pekarangan) 


\section{DAFTAR GAMBAR}

No

Halaman

1. Kerangka Pikir Penelitian 3

2. Batas Kawasan Penelitian Perkampungan Budaya

Betawi, Setu Babakan

3. Akses Masuk Kawasan Rekreasi Setu Babakan

4. Kondisi Umum Kawasan Lingkar Setu Babakan.................................. 25

5. Aktivitas pada Kawasan Lingkar Setu Babakan ................................... 34

6. Pohon Langka Di Setu Babakan .......................................................... 42

7. Peta Sebaran Pohon Lingkar Setu Babakan (Bagian 1) ......................... 43

8. Peta Sebaran Pohon Lingkar Setu Babakan (Bagian 2)......................... 44

9. Peta Sebaran Pohon Lingkar Setu Babakan (Bagian 3) ......................... 45

10. Peta Sebaran Pohon Lingkar Setu Babakan (Bagian 4) ........................ 46

11. Pohon Lingkar Setu Babakan............................................................. 47

12. Pohon pada Area Pekarangan............................................................ 49

13. Sebaran Penilaian Vegetasi Modifikasi Suhu sebagai Penaung ............. 57

14. Sebaran Penilaian Vegetasi Kontrol Kelembaban Udara......................... 65

15. Sebaran Penilaian Vegetasi Peredam Kebisingan.................................. 68

16. Sebaran Penilaian Vegetasi Penahan Angin ......................................... 75

17. Sebaran Penilaian Vegetasi Kehadiran Satwa (Burung)........................ 78

18. Rekomendasi Konservasi Pohon................................................................ 95

19. Rekomendasi Keragaman Pohon ........................................................ 96

20. Rekomendasi Fungsi Ekologis Pohon................................................ 97

21. Peta Sintesis Sebaran Fungsi Ekologis Pohon ....................................... 98

22. Rekomendasi Penataan Vegetasi dan Aktivitas Rekreasi ...................... 100 


\section{DAFTAR LAMPIRAN}

No

Halaman

1. Baku Tingkat Kebisingan.

107

2. Jenis-Jenis Vegetasi (Pohon dan Semak) yang

Cocok sebagai Habitat Burung.............................................................. 108

3. Jenis-Jenis Pohon pada Area Studi Perkampungan

Budaya Betawi Setu Babakan 


\section{BAB I \\ PENDAHULUAN}

\subsection{Latar Belakang}

Perkampungan Budaya Betawi termasuk Setu Babakan di dalamnya, merupakan sebuah kawasan budaya di wilayah Jakarta Selatan yang masih dijaga nilai ekologisnya melalui keberadaan vegetasi. Di wilayah tersebut terdapat ș perbaikan infrastruktur, fasilitas, dan pergerakan ekonomi pada area tersebut. Eingkungan sekitar danau banyak digunakan oleh warga lokal dan pengunjung yäng terdiri dari warga Jakarta atau luar Jakarta untuk bersantai dan berkumpul. Setu Babakan sebagai salah satu ruang terbuka hijau kota Jakarta kondisinya cukup sejuk dan nyaman. Tidak jarang pada area-area tertentu juga masih dapat terdengar suara kicauan burung yang mampu menambah suasana keasrian. Pada kawasan ini juga terdapat wisata agro sebagai bagian dari bentuk kegiatan pariwisata yang memanfaatkan usaha pertanian (agro) sebagai objek wisata dengan tujuan rekreasi, keperluan ilmu pengetahuan, memperkaya pengalaman dan memberikan peluang usaha di bidang pertanian. Hal yang menjadi daya tarik dan keunikan wisata agro di Perkampungan Budaya Betawi adalah lokasi pertanian tidak berada pada area khusus, melainkan berada di pelataran dan halaman rumah-rumah penduduk. Pada saat musim buah datang, keranumannya akan sangat memikat pengunjung untuk singgah di rumah-rumah penduduk. Kondisi ini menunjukkan adanya suatu nilai dari kearifan lingkungan lokal yang sangat erat hubungannya dengan keberadaan vegetasi untuk fungsi ekologis bagi kenyamanan serta keragamannya untuk studi.

Pohon sebagai salah satu elemen pembentuk unsur vegetasi pada kawasan memiliki peran yang sangat penting untuk menjaga kelestarian lingkungan dan ekosistem. Perkampungan Budaya Betawi, termasuk area Setu Babakan di dalamnya memiliki jenis-jenis pohon yang beragam. Beberapa di antaranya tergolong pohon-pohon langka yang menjadi ciri khas dari kota Jakarta. Secara Tangsung nilai keragaman yang paling terlihat dapat diketahui melalui warna daun dan tekstur tajuk. Kawasan ini kemudian dapat dikatakan sebagai hutan kota oleh 
karena unsur keragaman vegetasi yang dimilikinya serta mampu dijadikan area studi bagi peneliti dan pelajar.

Keberadaan populasi pohon pada kawasan juga berperan penting dalam memperbaiki kualitas lingkungan. Fungsi ekologis yang diberikan terkait dengan ameliorasi iklim dan kehadiran satwa, seperti burung, sebagai pembentuk ekosistem yang lebih sempurna. Menurut Grey dan Deneke (1978), melalui penggunaan vegetasi pohon yang baik, suatu iklim mikro mampu terbentuk dan đapat mengameliorasi iklim di sekitarnya untuk memberikan kenyamanan bagi mianusia. Fungsi ekologis pohon bagi kenyamanan manusia dan lingkungan sekitar antara lain mampu memodifikasi suhu, mengontrol kelembaban udara, serta mereduksi polutan. Selain itu, nyaman bagi kehadiran satwa seperti burung yang kemudian menjadi habitat bagi mereka untuk bereproduksi dan mencari makan.

Masalah ruang terbuka hijau kota besar seperti Jakarta, kian menjadi sorotan utama terhadap efektifitas fungsi yang dapat diberikan untuk kawasan sebagai jawaban atas permasalahan lingkungan di dalamnya. Terkait permasalahan tersebut, keberadaan hutan kota dirasa mampu memberikan peranan penting melalui fungsi-fungsinya, seperti menjaga kualitas lingkungan dan kelestarian vegetasi. Oleh karena itu dibutuhkan suatu kajian terhadap nilai keragaman vegetasi pohon dan fungsi ekologisnya sehingga mampu memberikan manfaat, baik untuk lingkungan maupun makhluk hidup di dalamnya.

\subsection{Tujuan}

1. menginventarisasi jenis-jenis pohon pada lanskap area rekreasi Setu Babakan

2. menganalisis nilai keragaman pohon pada pekarangan lingkar danau dan area rekreasi Setu Babakan

3. menganalisis fungsi ekologis pohon pada pekarangan lingkar danau dan area rekreasi Setu Babakan

4. memberikan rekomendasi untuk peningkatan kualitas lingkungan dan sisi ekologi pemanfaatan pohon 


\subsection{Kerangka Pikir}

Berdasarkan latar belakang dan tujuan dari penelitian di Perkampungan Budaya Betawi Setu Babakan, maka diperoleh sebuah kerangka pikir yang dapat dilihat pada Gambar 1.

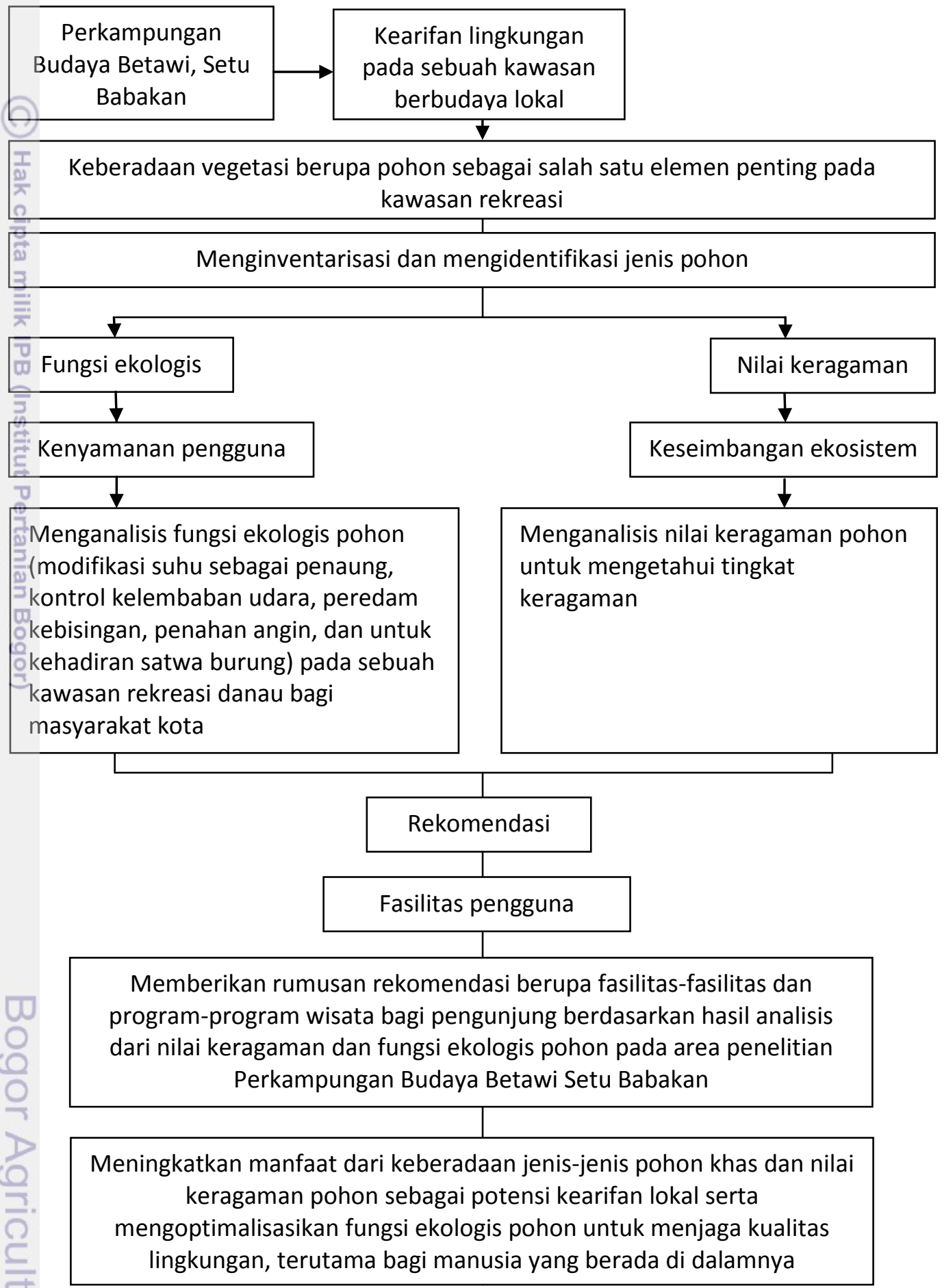

Gambar 1. Kerangka Pikir Penelitian 
Pada penelitian ini dikaji nilai keragaman pohon pada beberapa tipe RTH di dalam kawasan Setu Babakan serta fungsi ekologisnya sehingga diperoleh hasil berupa tingkat keragaman pohon beserta tingkat kesesuaian fungsi ekologis pohon untuk kawasan tersebut. 


\section{BAB II}

\section{TINJAUAN PUSTAKA}

\subsection{Ekologi}

Istilah ekologi digunakan pertama kali oleh Arnest Haeckel pada pertengahan tahun 1860an. Istilah ini berasal dari bahasa Yunani, yaitu oikos yang memiliki arti rumah dan logos yang memiliki arti ilmu. Jadi ekologi secara Tarfiahnya dapat diartikan sebagai ilmu tentang makhluk hidup dalam rumahnya atau juga dapat dikatakan sebagai ilmu tentang rumah tangga makhluk hidup. Ëkologi mencakup beberapa komponen yang tergabung di dalam suatu ekosistem đäri seluruh alam semesta. Komponen-komponen tersebut terdiri dari individu, populasi, komunitas, ekosistem, dan biosfer.

Menurut Harmoni (1994), manusia di dalam kehidupannya menempati Æingkungan biotik dan lingkungan abiotik. Manusia bertugas untuk berjuang melestarikan alam agar tetap hidup, namun di sisi lain dapat menimbulkan kerusakan terhadap tatanan lingkungan hidup akibat perilakunya. Salah satu akibatnya adalah timbulnya krisis lingkungan yang tampak jelas berakibat negatif tẹrhadap kesehatan manusia, seperti bahaya polutan. Polusi dapat tergolong ke dalam polusi udara, polusi air dan tanah, serta polusi suara.

\subsection{Fungsi Ekologis Pohon}

Setu Babakan merupakan salah satu area rekreasi ruang terbuka hijau hutan kota yang ada di Jakarta. Oleh karena itu, selain kehadiran badan air berupa danau, keberadaan pohon pada tapak juga mampu menawarkan kenyamanan bagi pengunjung yang datang, melalui fungsi ekologisnya. Terdapat lima aspek utama (fungsi ekologis yang perlu diperhatikan dari keberadaan pohon pada Setu Babakan, terutama yang mampu memberikan kenyamanan bagi pengunjung seperti aktivitas bersantai, memperoleh ketenangan, menikmati pemandangan, bersantap, dan memancing. Aspek fungsi ekologis yang sesuai bagi kebutuhan pengunjung tersebut antara lain modifikasi suhu sebagai penaung, kontrol kelembaban udara, peredam kebisingan, penahan angin, dan untuk kehadiran satwa burung. 


\subsubsection{Modifikasi Suhu sebagai Penaung}

Pohon merupakan vegetasi yang paling efektif untuk mereduksi suhu panas berlebih di dalam area perkotaan. Tipe-tipe ruang terbuka, secara spesifik yaitu area yang terlindungi oleh kanopi pohon dengan persentase tinggi dan permukaan air merupakan area yang paling sejuk di dalam wilayah perkotaan. Peningkatan jumlah kanopi pohon sebesar 10\% dapat mereduksi suhu permukaan rata-rata sebesar $1,4^{\circ} \mathrm{C}$ di saat siang hari selama musim kering (Pauleit and Duhme 2000).

음. Menurut Oke (1989), modifikasi atau reduksi suhu oleh pohon dipengaruhi gleh dua faktor, yaitu terjadinya bayangan secara langsung dan pendinginan melalui evapotranspirasi. Timbulnya suatu area dengan temperatur yang tinggi (3 hingga $10^{\circ} \mathrm{F}$ lebih hangat dari area di sekitarnya) disebabkan oleh berkurangnya ạngin, meningkatnya densitas permukaan, dan panas yang dihasilkan oleh àktivitas manusia, yaitu semua yang membutuhkan energi tambahan yang dikeluarkan hingga berlebih. Keberadaan pohon dapat dengan baik mengurangi đampak dari timbulnya suhu yang tinggi pada suatu area. Pohon mengurangi suhu melalui bayangan yang menutupi permukaan suatu lahan, menghilangkan panas melalui evapotranspirasi, dan mengontrol pergerakan udara (Coder 1996).

\subsubsection{Kontrol Kelembaban Udara}

Pepohonan memiliki fungsi menangkap dan menyaring radiasi sinar matahari, mencegah terjangan angin, mentranspirasi air, serta mereduksi evaporasi pada kelembaban tanah. Di bawah kanopi yang terdapat pada hutan, biasanya kelembaban bersifat lebih tinggi sedangkan tingkat evaporasi lebih rendah. Suhu di bawah kanopi juga lebih rendah dibandingkan dengan udara di sekitarnya pada (saat siang hari dan lebih hangat saat malam hari (Grey dan Deneke 1978).

Seiring dengan efek yang diberikan dari keberadaan pohon terhadap suhu, tumbuhan tersebut sangat penting peranannya di dalam siklus hidrologi. Pohon menangkap presitipasi dan mengurangi kecepatan penurunannya ke permukaan tanah. Hal ini dapat meningkatkan infiltrasi serta mengurangi runoff dan erosi tanah. Pohon juga dapat mereduksi evapotranspirasi dari kelembaban tanah. Akan tetapi, tingkat transpirasi tinggi yang dimiliki pohon dan proses penangkapan 
presipitasi yang dilakukannya dapat mereduksi jumlah air yang ada untuk persediaan kebutuhannya dan mengurangi aliran sungai apabila dibandingkan dengan jenis vegetasi lain. Seluruh faktor-faktor tersebut sangat penting untuk wilayah perkotaan, oleh karena persediaan sumber air alami di bawah tanah adalah sumber daya utama untuk pemenuhan kebutuhan air (Grey dan Deneke 1978).

Suatu kawasan memiliki efektifitas dan kemampuan yang berbeda, dalam mengontrol runoff dan proses infiltrasi yang dipengaruhi oleh tipe tanah, kadar bahan organik di dalam tanah, topografi, tipe dan intensitas dari presipitasi, dan komposisi penutupan vegetasi. Penangkapan presipitasi oleh pohon-pohon berdaun jarum biasanya lebih baik daripada pohon-pohon berdaun lebar dan lebat. Diestimasikan bahwa 60 persen dari hujan akan sampai pada tanah melalui pohonpohon berdaun jarum seperti pinus, sedangkan 80 persen untuk pohon berdaun lebar dan lebat. Hal ini dikarenakan oleh struktur daun yang dimiliki pohon berdaun jarum memudahkan penangkapan yang lebih baik terhadap butiran air hujan. Peremajaan adalah karakteristik lain yang penting di dalam penangkapan air. Pola percabangan juga mempengaruhi tingkat kemampuan penangkapan air, yaitu pola percabangan horizontal, yang paling efektif (Grey dan Deneke 1978).

\subsubsection{Penahan Angin}

Sebagai kawasan rekreasi, wisata, dan tempat tinggal, fungsi pohon sebagai penahan angin sangatlah penting bagi Perkampungan Budaya Betawi, Setu Babakan untuk mereduksi jumlah angin yang masuk dan menghindari efekefek buruk yang dapat ditimbulkan bagi kenyamanan pengguna. Berdasarkan publikasi ilmiah dari Washington State University (2003), salah satu komponen cutama di dalam mendisain suatu pemecah angin adalah ketercapaian kerapatan yang sesuai. Kerapatan atau porositas angin merupakan persentase dari elemen struktural yang digunakan untuk menahan angin. Semakin meningkatnya kerapatan, perlindungan terhadap angin yang seketika mendekati pemecah secara umum meningkat daripada perlindungan yang lebih sedikit, jauh dari pohon penahan angin. Pemilihan terhadap tanaman yang baik untuk digunakan harus memenuhi kriteria, seperti kemampuan untuk tumbuh dengan baik, kemampuan 
untuk menahan angin, dan secara estetik mampu memberi kepuasan terhadap pengguna.

Pohon mengurangi kecepatan angin dan membuat zona perlindungan menghindari angin. Efek yang lebih besar timbul dari kerapatan penanaman pohon konifer daripada penanaman pohon deciduous dan semak. Pohon dan semak mengontrol angin dengan halangan, petunjuk, defleksi, dan filtrasi (Grey dan Deneke, 1978). Halangan tersebut mempengaruhi peletakan tanaman dalam mengurangi kecepatan angin dengan meningkatkan perlawanan terhadap aliran ångin. Grey dan Deneke (1978) juga mengungkapkan bahwa tingkat proteksi suatu area terhadap angin memiliki ketergantungan pada ketinggian pohon. Angin yäng tegak lurus terhadap deretan tanaman penahan angin gerakannya akan dipengaruhi jarak 5 hingga 10 kali tinggi tanaman pada ruang di dekat pohon sampai 30 kali tinggi tanaman pada bagian belakang.

\subsubsection{Peredam Kebisingan}

Kebisingan adalah bunyi yang tidak diinginkan dari usaha atau kegiatan dalam tingkat dan waktu tertentu yang dapat menimbulkan gangguan kesehatan m̧anusia dan kenyamanan lingkungan (KEP-48/MENLH/11/1996). Lalu lintas jalan merupakan sumber utama kebisingan yang dapat mengganggu sebagian besar masyarakat perkotaan. Sumber kebisingan lalu lintas jalan antara lain berasal dari kendaraan bermotor, baik roda dua, tiga maupun roda empat, dengan sumber penyebabnya berasal dari bunyi klakson saat kendaraan ingin mendahului atau meminta jalan dan saat lampu lalu lintas tidak berfungsi (Departemen Kesehatan RI 1995). Adapun baku tingkat kebisingan dapat dilihat pada Lampiran 1.

Dewasa ini masyarakat telah menganggap kebisingan sebagai salah satu polusi di dalam lingkungan. Pada beberapa kondisi tertentu, hal ini juga telah menjadi permasalahan kesehatan yang diperbincangkan di dunia internasional. Agar lingkungan tetap terjaga, dibutuhkan suatu upaya untuk mereduksi dampak yang dapat ditimbulkan, seperti penanaman pohon yang dapat mereduksi kebisingan sebesar 5 hingga $10 \mathrm{~dB}$. Menurut USDA National Agricultural Center (1997), terdapat beberapa rekomendasi secara umum untuk mereduksi kebisingan 
melalui hijauan, seperti menanam tanaman penyangga dekat dengan sumber kebisingan, menggunakan tanaman bertajuk padat apabila memungkinkan, menggunakan penutupan melalui hijauan secara menyeluruh (mulai dari permukaan tanah), menggunakan pohon tinggi apabila memungkinkan, memilih pohon yang tumbuh hijau sepanjang tahun (daunnya tidak mengalami siklus gugur), serta menanam tanaman secara berdekatan.

Pohon dapat meredam suara dengan cara mengabsorpsi gelombang suara ฮ̄ suara ialah yang mempunyai tajuk yang tebal dengan daun yang rindang (Grey dan Deneke, 1978). Penanaman berbagai jenis tanaman dengan berbagai strata yäng cukup rapat dan tinggi mampu mengurangi kebisingan, khususnya dari kebisingan yang sumbernya berasal dari bawah. Menurut Grey dan Deneke (1978), daun-daun dari tanaman dapat menyerap kebisingan hingga 95\%

Menurut hasil penelitain yang dilakukan oleh Aisah, Tandjung, dan Hadisusanto (2002), kemampuan meredam kebisingan tumbuhan dapat đipengaruhi oleh beberapa faktor, salah satunya adalah faktor yang berasal dari parameter tumbuhan itu sendiri. Parameter keanekaragaman jenis tumbuhan m̧empunyai peranan yang cukup penting walaupun semakin tinggi keanekaragaman jenis tumbuhan tidak diikuti dengan semakin tingginya efektifitas peredam kebisingan. Tinggi batang lepas cabang pada tumbuhan juga mempunyai peranan yang lebih tinggi daripada tinggi kanopi tumbuhan, lebar kanopi tumbuhan, keliling batang tumbuhan, dan kerapatan tumbuhan dalam hal efektifitas peredaman kebisingan.

\subsubsection{Kehadiran Satwa (Burung)}

Kawasan Setu Babakan dengan berbagai jenis vegetasi pohon di dalamnya secara langsung telah berkontribusi terhadap keberadaan ruang terbuka hijau bagi wilayah Jakarta. Hal ini pula yang menjadikannya dapat disebut sebagai hutan kota. Area ini memiliki tipe hutan kota yang perlu disesuaikan dengan situasi dan kondisi setempat dan tujuan pembangunannya. Salah satu tipe hutan kota adalah untuk pelestarian plasma nutfah (Fakuara 1982). Tujuan pembangunan kawasan 
ini adalah sebagai koleksi plasma nutfah dan habitat, khususnya untuk satwa yang dilindungi atau yang akan dikembangkan sesuai dengan perkembangan vegetasi.

Kehadiran burung sangat berperan untuk dapat menciptakan kawasan yang asri dan mampu mengakomodasi habitat satwa tersebut melalui keragaman jenisnya. Menurut Hernowo dan Prasetyo (1989), peranan hutan kota untuk satwa burung secara khususnya yaitu sebagai tempat mencari makan maupun sebagai tempat bersarang dan bertelur. Terdapatnya jenis pohon yang disukai oleh burung añtara lain dikarenakan oleh adanya buah, nektar, bunga, ijuk, dan batangnya yang menarik.

Menurut Yayasan Kutilang Indonesia (2012), terdapat daftar jenis vegetasi (pohon dan semak) yang memiliki manfaat lebih untuk burung dari seorang peneliti burung bernama Bas van Ballen yang terdiri dari jenis-jenis yang ditanam di pekarangan rumah, taman kota, serta hutan kota dan bantaran sungai. Jenisjênis vegetasi tersebut dapat dilihat pada Tabel 1.

Tabel 1. Daftar Jenis Vegetasi (Pohon dan Semak) untuk Burung

\begin{tabular}{|c|c|c|c|c|c|}
\hline $\begin{array}{l}\text { J } \\
\circ \\
\stackrel{\circ}{\circ} \\
\text { @No }\end{array}$ & Nama Latin & Nama Lokal & Pekarangan & $\begin{array}{c}\text { Taman } \\
\text { Kota }\end{array}$ & $\begin{array}{c}\text { Hutan Kota } \\
\text { dan } \\
\text { Bantaran } \\
\text { Sungai } \\
\end{array}$ \\
\hline 1 & Agathis damara & Damar & & & v \\
\hline 2 & Aglaia odorata & Kemuning & & $\mathrm{v}$ & \\
\hline 3 & Albizia sp. & Albisia & & & $v$ \\
\hline 4 & Aleurites moluccana & Kemiri & & & v \\
\hline 5 & $\begin{array}{l}\text { Alkesa pouteria } \\
\text { campechiana }\end{array}$ & Sawo & & v & \\
\hline 6 & Alstonia scholaris & Pule & & & v \\
\hline 7 & Antidesma bunius & Buni & $v$ & & \\
\hline 8 & Averhoa bilimbi & $\begin{array}{l}\text { Belimbing } \\
\text { sayur }\end{array}$ & v & & \\
\hline & Alpinia galangal & Lengkuas & v & & \\
\hline 10 & Areca catechu & Pinang & & v & \\
\hline 11 & Areca vestiaria & $\begin{array}{l}\text { Pinang } \\
\text { merah }\end{array}$ & & v & \\
\hline 912 & Arenga pinnata & Aren & & & v \\
\hline-13 & Baccaurea racemosa & Menteng & & v & \\
\hline 14 & Barringtonia asiatica & Keben & & & v \\
\hline 15 & Bauhinia purpurea & Kupu-kupu & & v & \\
\hline
\end{tabular}


Tabel 1. Daftar Jenis Vegetasi (Pohon dan Semak) untuk Burung (Lanjutan)

\begin{tabular}{|c|c|c|c|c|}
\hline Nama Latin & Nama Lokal & Pekarangan & $\begin{array}{l}\text { Taman } \\
\text { Kota }\end{array}$ & $\begin{array}{c}\text { Hutan Kota } \\
\text { dan } \\
\text { Bantaran } \\
\text { Sungai }\end{array}$ \\
\hline 16 Bouea macrophylla & Gandaria & & $\mathrm{v}$ & \\
\hline 17 Bougainvillea glabra & Bugenvil & v & & \\
\hline 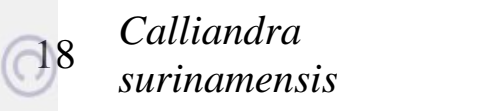 & Kaliandra & v & & \\
\hline $\begin{array}{ll}\text { T } & \text { Calophyllum } \\
\text { ingopphyllum }\end{array}$ & Nyamplung & & & v \\
\hline 20 Cananga odorata & Kenanga & & v & \\
\hline $\begin{array}{ll}\text { Canarium } \\
\text { decumanum }\end{array}$ & Kenari babi & & & v \\
\hline$\overline{22}$ Carmona relusa & Serutan & & & v \\
\hline 23 Caryota mitis & $\begin{array}{l}\text { Palem } \\
\text { seledri }\end{array}$ & & & v \\
\hline 24 Ceiba pentandra & Randu & & & v \\
\hline $\begin{array}{ll} & \text { Chrysophyllum } \\
& \text { cainito }\end{array}$ & Sawo duren & & v & \\
\hline $\begin{array}{ll}\text { Cinnamomum } \\
\text { (0) }\end{array}$ & Kayu manis & & v & \\
\hline 27 Corypha gebanga & Gebang & & & v \\
\hline 28 Cyrtotachys lakka & $\begin{array}{l}\text { Palem } \\
\text { merah }\end{array}$ & v & & \\
\hline $29 \begin{array}{l}\text { Dillenia } \\
\text { philippinensis }\end{array}$ & Sempur & & & v \\
\hline $30 \begin{array}{l}\text { Diospyros } \\
\text { philipinensis }\end{array}$ & Bisbul & v & & \\
\hline 31 Erythrina cristagalli & Dadap & & & $v$ \\
\hline 32 Erythrina variegata & $\begin{array}{l}\text { Dadap } \\
\text { belang }\end{array}$ & & v & \\
\hline Euphoria longans & Lengkeng & & & v \\
\hline Ficus sp. & Beringin & & & $v$ \\
\hline Flacourtia rukam & Rukem & & & \\
\hline Garcinia dulcis & Mundu & & v & \\
\hline Gigantochloa apus & Bambu tali & & & v \\
\hline Gigantochloa atter & $\begin{array}{l}\text { Bambu } \\
\text { hitam }\end{array}$ & & & v \\
\hline 9 Gnetum gnemon & Melinjo & & $v$ & \\
\hline $\begin{array}{ll}\overline{4} 0 & \begin{array}{l}\text { Gossampinus } \\
\text { heptaphylla }\end{array}\end{array}$ & Dangdeur & & & v \\
\hline 41 Heliconia collinsiana & Pisang hias & v & & \\
\hline 42 Inocarpus fagifer & Gayam & & & $v$ \\
\hline
\end{tabular}


Tabel 1. Daftar Jenis Vegetasi (Pohon dan Semak) untuk Burung (Lanjutan)

\begin{tabular}{|c|c|c|c|c|}
\hline Nama Latin & Nama Lokal & Pekarangan & $\begin{array}{l}\text { Taman } \\
\text { Kota }\end{array}$ & $\begin{array}{c}\text { Hutan Kota } \\
\text { dan } \\
\text { Bantaran } \\
\text { Sungai } \\
\end{array}$ \\
\hline 43 Jasminum sambac & Melati & $\mathrm{v}$ & & \\
\hline 44 Lantana camara & Cente & v & & \\
\hline 45 Licuala grandis & Palem & $v$ & & \\
\hline $46 \quad$ Magnolia alba & $\begin{array}{l}\text { Cempaka } \\
\text { putih }\end{array}$ & & v & \\
\hline Magnolia liliifera & $\begin{array}{l}\text { Cempaka } \\
\text { gondok }\end{array}$ & & v & \\
\hline 48 Manilkara achras & Sawo & & v & \\
\hline 49 Manilkara kauki & Sawo kecik & & v & \\
\hline 50 Mesua ferrea & Dewandaru & & & $v$ \\
\hline 51 Mischelia champaka & Cempaka & & $v$ & \\
\hline 52 Mimusoph elengi & Tanjung & & & v \\
\hline 53 Morinda citrifolia & Mengkudu & & v & \\
\hline 54 Morus sp. & Murbei & v & & \\
\hline 95 Myristica fragrans & Pala & & & v \\
\hline $\begin{array}{l}\text { Oncosperma } \\
\text { filamentosa }\end{array}$ & Oksosperma & & v & \\
\hline 57 Pangium edule & Kluwak & & & v \\
\hline 958 Parkia speciosa & Petai & & & v \\
\hline 59 Perikopsis mooniana & Perikopsis & & & v \\
\hline 60 Phyllanthus acidus & Ceremai & & $v$ & \\
\hline 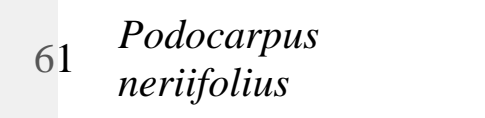 & Kiputri & & v & \\
\hline 62 Pometia pinnata & Matoa & & v & \\
\hline 63 Roystonea regia & Palem raja & & v & \\
\hline 64 Salacca zalacca & Salak & & $v$ & \\
\hline 65 Samanea saman & Ki Hujan & & & v \\
\hline 066 Sandoricum koetjape & Kecapi & & v & \\
\hline 67 Santalum album & Cendana & & $\mathrm{v}$ & \\
\hline 68 Sesbania grandiflora & Turi & v & & \\
\hline $69 \begin{array}{l}\text { Spathodea } \\
\text { campanulata }\end{array}$ & Kiacret & & v & \\
\hline $70 \quad$ Spondias dulcis & Kedondong & & v & \\
\hline $\begin{array}{ll}\exists 1 & \text { Stelechocarpus } \\
\square & \text { burahol }\end{array}$ & Kepel & & v & \\
\hline 72 Sterculia foetida & Kepuh & & & $v$ \\
\hline $\begin{array}{ll}73 & \text { Swietenia } \\
& \text { macrophylla }\end{array}$ & Mahoni & & & v \\
\hline
\end{tabular}


Tabel 1. Daftar Jenis Vegetasi (Pohon dan Semak) untuk Burung (Lanjutan)

\begin{tabular}{|c|c|c|c|c|c|}
\hline No & Nama Latin & Nama Lokal & Pekarangan & $\begin{array}{l}\text { Taman } \\
\text { Kota }\end{array}$ & $\begin{array}{c}\text { Hutan Kota } \\
\text { dan } \\
\text { Bantaran } \\
\text { Sungai }\end{array}$ \\
\hline 74 & Syzygium aqueum & Jambu air & & $\mathrm{v}$ & \\
\hline 75 & $\begin{array}{l}\text { Syzygium } \\
\text { aromaticum }\end{array}$ & Cengkeh & & $v$ & \\
\hline त6 & Syzygium commune & Jamblang & & v & \\
\hline 77 & Syzygium jambos & $\begin{array}{l}\text { Jambu } \\
\text { mawar }\end{array}$ & & $v$ & \\
\hline 978 & $\begin{array}{l}\text { Syzygium } \\
\text { malaccensis }\end{array}$ & Jambu bol & & $v$ & \\
\hline$\exists 9$ & Syzygium polyanthum & Salam & & v & \\
\hline 80 & $\begin{array}{l}\text { Syzygium } \\
\text { polycephalum }\end{array}$ & Gowok & & $v$ & \\
\hline 81 & Terminalia catappa & Ketapang & & v & \\
\hline 82 & Trema orientalis & Anggerung & & $v$ & \\
\hline 83 & Triphasia trifolia & $\begin{array}{l}\text { Jeruk } \\
\text { kingkit }\end{array}$ & $v$ & & \\
\hline 84 & Vitex sp. & Laban & & & v \\
\hline 85 & Zingiber officinale & Jahe & v & & \\
\hline 86 & Ziziphus mauritiana & Widara & & v & \\
\hline
\end{tabular}

Sumber: Yayasan Kutilang Indonesia (2012)

\subsection{Keragaman Pohon}

Keragaman pohon berkaitan erat dengan taksonomi, termasuk floristik dan dendrologi yang diperlukan untuk dapat mengenal jenis-jenisnya. Menurut Soerianegara dan Indrawan (2008), untuk keperluan di lapangan dibutuhkan cara pengenalan jenis pohon yang didasarkan pada sifat-sifat vegetatif, yaitu sifat-sifat batang pohon (kulit, getah, dan kayu), daun dan kuncup, kemudian sifat-sifat generatifnya.

Terdapat faktor-faktor yang dapat mempengaruhi keragaman dan persebaran jenis pohon. Pertama, keadaan topografi atau relief yang mempengaruhi komposisi dan kesuburan tegakan populasi pohon, melalui perbedaan pada kesuburan dan keadaan air tanah. Selain itu, perbedaan letak tinggi juga mempengaruhi penyebaran tumbuh-tumbuhan melalui perbedaan iklim yang ditimbulkannya. Kedua, perbedaan jenis tanah, sifat-sifat serta keadaannya dapat mempengaruhi penyebaran tumbuh-tumbuhan, menyebabkan terbentuknya 
tipe-tipe vegetasi berlainan, serta mempengaruhi kesuburan dan produktivitas kawasan. Ketiga, faktor iklim seperti suhu, curah hujan, kelembaban, dan defisit tekanan uap air yang memilki pengaruh besar pada pertumbuhan pohon. Iklim mikro pada suatu area yang dipengaruhi kondisi topografi dapat mempengaruhi penyebaran dan pertumbuhan pohon (Soerianegara dan Indrawan 2008).

Selain faktor-faktor yang mempengaruhinya, geografi tumbuhan dapat membantu dalam mengetahui pola penyebaran berbagai jenis pohon dalam hübungan dengan keadaan fisik bumi, terutama iklim dan geomorfologi atau fisiografi.

\section{(i) \\ 3 \\ 2.4 Lanskap Budaya}

Lanskap budaya merefleksikan suatu interaksi antara manusia dengan Fingkungan alam sekitarnya pada area dan waktu tertentu. Alam pada konteks ini merupakan bagian yang tidak terpisahkan dari komunitas masyarakat di dalamnya. Keduanya saling berkaitan satu sama lain membentuk karakter lanskap. Pada beberapa bagian wilayah di dalam dunia ini, lanskap budaya berkembang sebagai model interaksi antara manusia, sistem sosial, dan cara mereka m̧engorganisasi ruang di mana mereka tinggal. Lanskap budaya juga menjadi sebuah fenomena yang kompleks melalui identitasnya yang terlihat secara langsung maupun tersirat dan dapat dirasakan (Droste et al 1995).

Lanskap budaya tergolong ke dalam lanskap yang dilindungi. Lucas (1992) menyebutkan bahwa terdapat beberapa kategori yang membedakan sifat dari tipe-tipe area yang dilindungi tersebut. Kawasan Perkampungan Budaya Betawi, Setu Babakan dalam hal ini tergolong ke dalam kelompok B kategori VII, yaitu sebagai natural biotic area atau anthropological reserve. Kondisi lanskap dengan segala kegiatan sosial di dalamnya pada kategori ini mengikuti gaya hidup dari komunitas suatu manusia yang hidup secara harmonis dengan lingkungan alam untuk menghindari intervensi yang datang dari teknologi modern.

Menurut Lucas (1992), terdapat enam nilai manfaat utama yang baik dimiliki oleh sebuah lanskap budaya. Pertama, keberadaannya dapat mengkonservasi keanekaragaman alam dan hayati, tidak hanya sebatas area dengan sumber daya alam di dalamnya melainkan juga ekosistem pada lanskap 
yang lebih luas, termasuk tanaman dan beragam jenis satwa yang telah berevolusi seiring dengan berkembangnya campur tangan manusia. Kedua, mengkonservasi bangunan dan praktek-praktek penggunaan lahan tertentu yang menyimpan sejarah manusia. Ketiga, memelihara gaya hidup lokal atau tradisional. Konsep yang dimiliki oleh lanskap yang dilindungi mampu memberikan hal tersebut melalui penyediaan sarana untuk mengontrol pembangunan yang tidak berbasis budaya lokal yang dapat merusak karakter sosial dari komunitas masyarakatnya. Keempat, mampu menawarkan kegiatan rekreasi dan inspirasi. Kelima, menawarkan nilai edukasi dan pemahaman yang dapat memberikan ilustrasi melalui contoh representatif terhadap bentukan-bentukan lanskap dari campur tângan manusia dan keberadaan manusianya itu sendiri dari lingkungan alami tempat di mana mereka tinggal. Keenam, mampu menunjukkan suatu sistem pada kegiatan pemanfaatan secara berkelanjutan yang selaras dengan alam. Kawasan ติi akan lebih baik mampu memberikan nilai ekonomi bagi tempat tinggal mereka, menjaga identitas budaya dari komunitas masyarakatnya, memberikan kepuasan secara sosial dan spiritual, serta nyaman melalui keindahannya.

\subsection{Ruang Terbuka Hijau}

Ruang Terbuka Hijau (RTH) kota adalah bagian dari ruang-ruang terbuka (open spaces) suatu wilayah perkotaan yang diisi oleh tumbuhan, tanaman, dan vegetasi (endemik, introduksi) guna mendukung manfaat langsung dan/atau tidak langsung yang dihasilkan oleh RTH kota tersebut berupa keamanan, kenyamanan, kesejahteraan, dan keindahan wilayah perkotaan (Departemen Pekerjaan Umum, 2005).

RTH terdiri dari fungsi utama berupa fungsi ekologis dan fungsi tambahan (berupa fungsi arsitektural, sosial, dan ekonomi. Keempat fungsi tersebut dapat dikombinasikan sesuai dengan kebutuhan, kepentingan, dan keberlanjutan pada suatu wilayah perkotaan. Fungsi ekologis RTH, yaitu untuk menjamin keberlanjutan suatu wilayah kota secara fisik. Bentuk RTH tersebut harus yang Ђerlokasi, berukuran, dan berbentuk pasti. Adapun RTH untuk fungsi lain merupakan RTH pendukung dan penambah nilai kualitas lingkungan dan budaya kota, sehingga dapat berlokasi dan berbentuk sesuai dengan kebutuhan dan 
kepentingannya. RTH berdasarkan fungsinya memiliki manfaat yang terdiri dari manfaat langsung, seperti memperoleh barang-barang untuk dijual, kenyamanan fisik, keinginan, serta manfaat tidak langsung seperti perlindungan tata air dan konservasi hayati atau keanekaragaman hayati (Departemen Pekerjaan Umum, 2005).

Pola RTH kota merupakan struktur RTH yang ditentukan oleh hubungan fungsional (ekologis, sosial, ekonomi, arsitektural) antar komponen

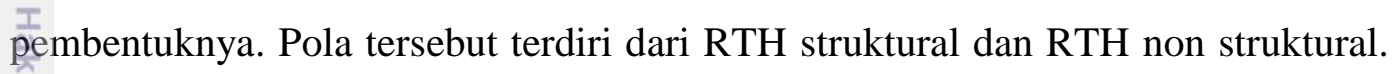
RTH struktural dibangun oleh hubungan fungsional antar komponen pembentuk yang mempunyai pola hierarki planologis yang bersifat antroposentris, didominasi 产eh fungsi-fungsi non ekologis dengan struktur RTH binaan yang berhierarki. Adapun RTH non struktural dibangun oleh hubungan fungsional antar komponen pembentuknya yang pada umumnya tidak mengikuti pola hierarki planologis $\vec{k}$ karena bersifat ekosentris, fungsi ekologisnya yang sangat dominan dengan struktur RTH alami yang tidak berhierarki (Departemen Pekerjaan Umum, 2005).

RTH dibangun dari kumpulan tumbuhan dan vegetasi yang telah diseleksi dản disesuaikan dengan lokasi beserta rencana dan rancangan penggunaan lạhannya. Jenis tanaman lokal yang memiliki keunggulan (ekologis, sosial budaya, ekonomi, arsitektural) pada suatu kota, akan mampu menjadi bahan tanaman utama penciri RTH kota bersangkutan. Hal ini selanjutnya dapat dikembangkan guna mempertahankan keanekaragaman hayati wilayahnya hingga secara nasional. Hadirnya permasalahan mengenai RTH pun tidak dapat dipungkiri. Tiga hal utama yang menyangkut ketersedian dan kelestarian RTH dapat diakibatkan oleh 1) dampak negatif dari suboptimalisasi RTH yang tidak memenuhi persyaratan jumlah dan kualitas, 2) lemahnya lembaga pengelola RTH,

(3) lemahnya peran stake holders, dan 4) keterbatasan lahan kota untuk peruntukan RTH (Departemen Pekerjaan Umum, 2005). 


\section{BAB III}

\section{METODOLOGI}

\subsection{Lokasi dan Waktu Penelitian}

Penelitian ini dilakukan pada area rekreasi Perkampungan Budaya Betawi Setu Babakan yang terletak di Kecamatan Jagakarsa, wilayah Jakarta Selatan. Area penelitian difokuskan pada dua kawasan inti untuk kegiatan rekreasi, yaitu area lingkar danau dan pekarangan warga yang berada di kawasan RT9 RTT10/RW8 (Gambar 2). Kawasan ini dikelilingi empat kelurahan, yaitu Kelurahan Jagakarsa di bagian utara, Kelurahan Kalisari di bagian timur, Kelurahan Srengsengsawah di bagian selatan, dan Kelurahan Ciganjur di bagian barat. Penelitian dilaksanakan pada bulan April hingga Agustus 2012.

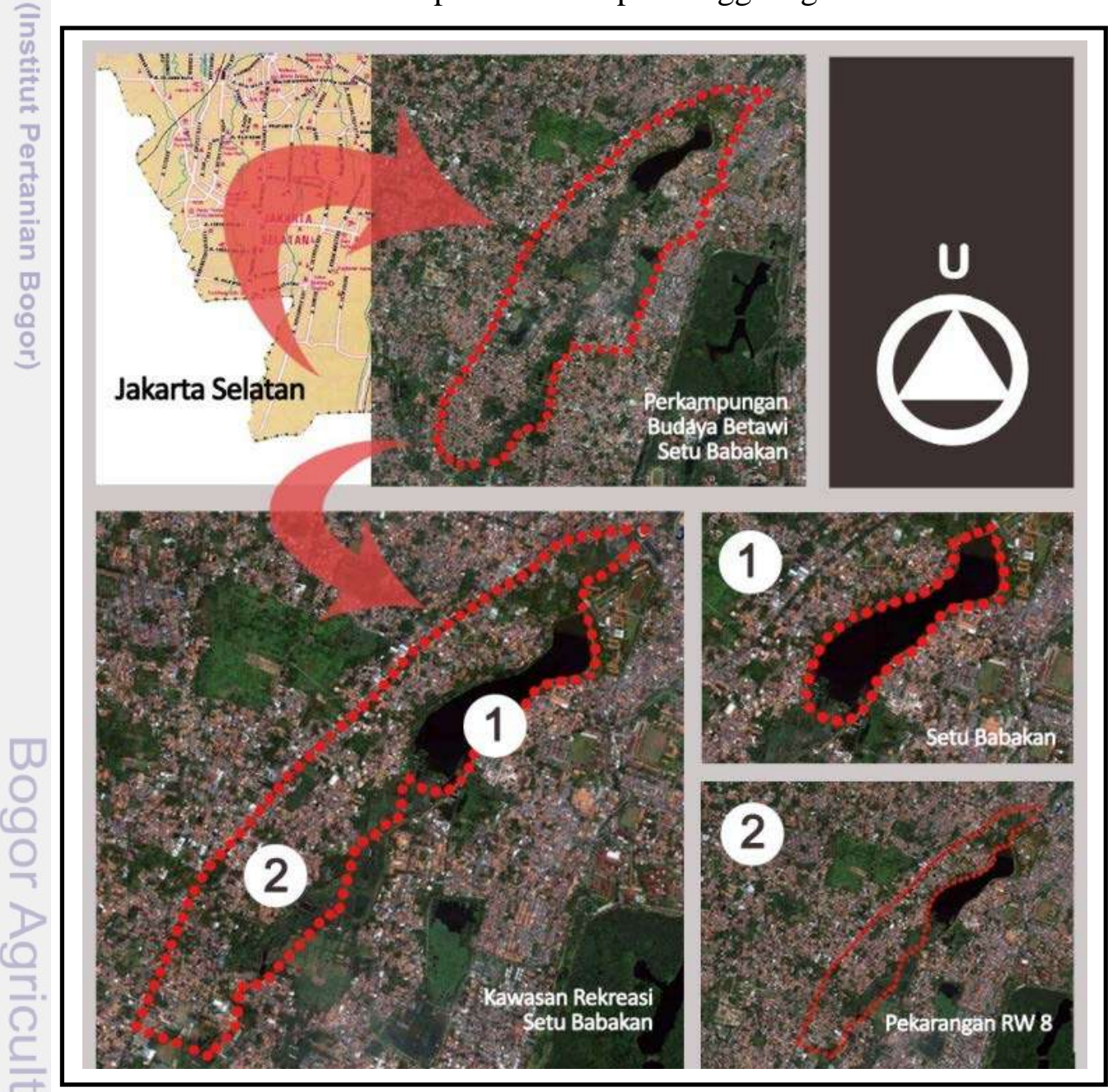

Gambar 2. Batas Kawasan Penelitian

Perkampungan Budaya Betawi, Setu Babaka 


\subsection{Bahan dan Alat}

Bahan yang digunakan antara lain peta, data tata guna lahan, data fisik dan biofisik, data iklim, dan data sosial. Alat yang digunakan antara lain GPS (Global Positioning System), Microsoft Excel, Microsoft Word, kalkulator, kamera, alat gambar, binocular, Photoshop CS3, Google Earth, dan Garmin.

\subsection{Tahapan Penelitian}

\subsubsection{Persiapan}

Pada tahapan ini, kegiatan terdiri dari penentuan lokasi penelitian, pembuatan usulan penelitian, konsultasi, pengumpulan data sekunder, pengkajian ștudi pustaka dan literatur, serta pengurusan izin penelitian. Jenis-jenis data yang digunakan dapat dilihat pada Tabel 2.

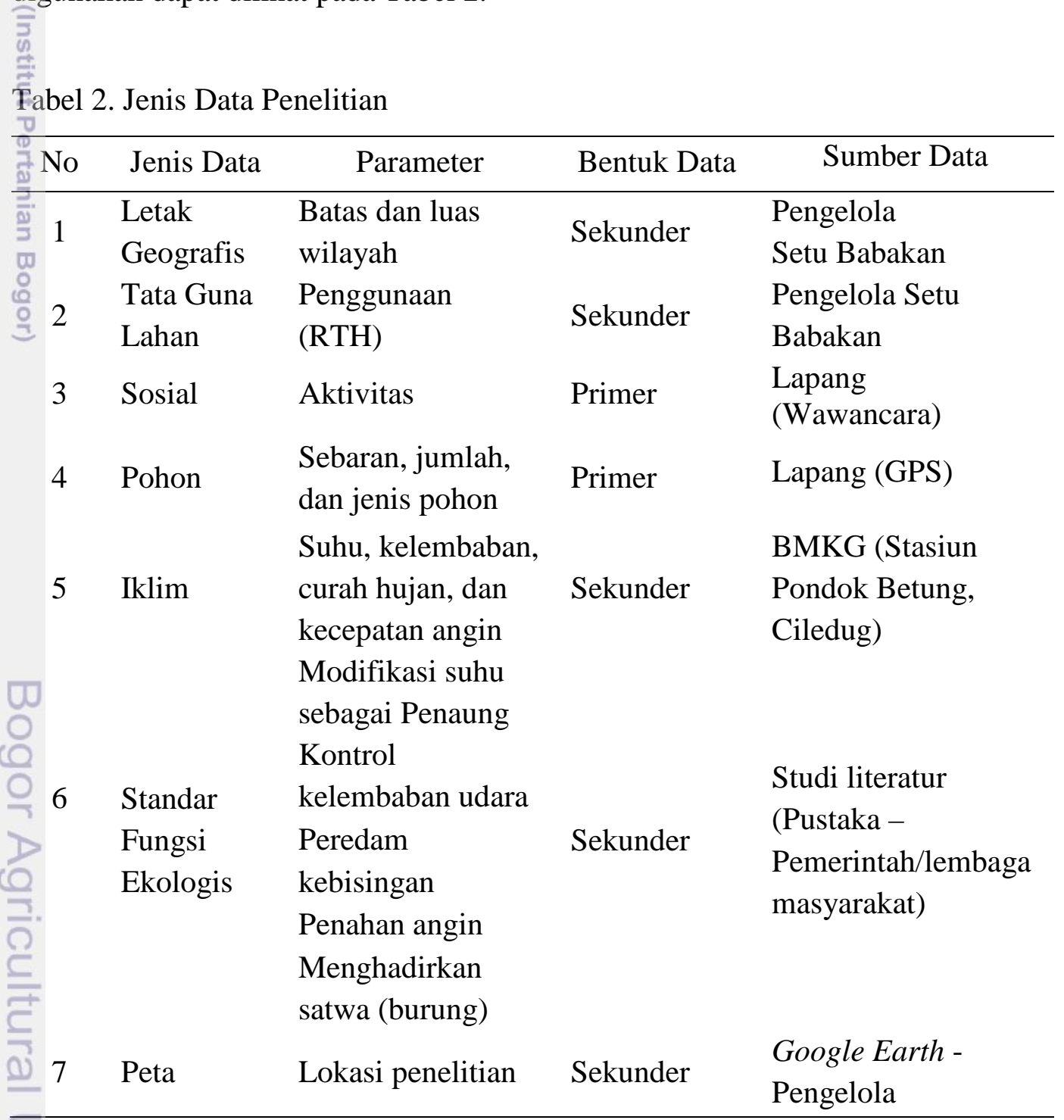




\subsubsection{Inventarisasi}

Kegiatan inventarisasi pada penelitian dilakukan dengan pengumpulan data primer dan data sekunder. Data primer terdiri dari jenis dan jumlah pohon yang diperoleh melalui proses identifikasi dan sensus terhadap seluruh individu pohon yang berada pada area lingkar setu dan masing-masing sepuluh pekarangan contoh. Parameter yang diamati yaitu pohon-pohon yang telah memiliki tinggi lebih dari $2 \mathrm{~m}$, dengan batang, daun, dan ranting yang lengkap atau masih memiliki kemampuan untuk tumbuh dengan baik (tidak dalam kondisi rusak akibat petir atau tumbang). Selain itu, data primer yang diperoleh antara lain sebaran titik-titik pohon pada area lingkar danau dengan menggunakan GPS, jenis-jenis pohon langka berdasarkan SK Gubernur DKI Jakarta Nomor: 2359/1987 mengenai tanaman yang dilindungi (Tabel 3), foto dokumentasi kondisi eksisting, dan hasil wawancara terhadap pihak-pihak terkait. Data sekunder diperoleh dari pihak pengelola Perkampungan Budaya Betawi Setu Babakan, Dinas Pertamanan dan Pemakaman Provinsi DKI Jakarta, BMKG Jakarta, serta undang-undang terkait lingkungan hidup.

Tabel 3. Jenis-Jenis Pohon Langka Jakarta

\begin{tabular}{|c|c|c|}
\hline No & Nama Lokal & Nama Latin \\
\hline 1 & Bisbol & Diospyros philipensis \\
\hline 2 & Buah Nona & Annona reticulata \\
\hline 3 & Buni & Antidesma reticulata \\
\hline 4 & Duku Condet & Lansium domesticum var Condet \\
\hline 5 & Durian Cipaku & Durio zibhentinus Cipaku \\
\hline 6 & Durian Sitokong & Durio zibhentinus Sitokong \\
\hline 7 & Gandaria & Buoea macrophila \\
\hline 8 & Gowok & Syzygium polychepalum \\
\hline 9 & Jambu Mawar & Eugenia jambos \\
\hline 10 & Jamblang & Eugenia cuminii \\
\hline 11 & Kawista Batu & Feronica lucida \\
\hline 12 & Kapulasan & Nephelium mutabile \\
\hline 13 & Kemang & Mangifera caesia \\
\hline 14 & Kepel & Stelechocarpus burahol \\
\hline 15 & Kweni & Mangifera odorata \\
\hline 16 & Lobi - Lobi & Floacourtia inermis \\
\hline 17 & Lechi & Leachi chinensis \\
\hline 78 & Malaka & Phylantus emblica \\
\hline 919 & Mengkudu & Morinda citrifolia \\
\hline 20 & Menteng & Baccuria rasemosa \\
\hline
\end{tabular}


Tabel 3. Jenis-Jenis Pohon Langka Jakarta (Lanjutan)

\begin{tabular}{lll}
\hline No & Nama Lokal & \\
\hline 21 & Mundu & Garcinta dulcis \\
22 & Nam Nam & Cynometro cauliflora \\
23 & Rukem & Falcourtia rukam \\
24 & Salak Condet & Salacca edulis cainato \\
25 & Sawo Kecik & Manilkara kauki \\
26 & Srikaya & Annona squamosa \\
\hline \multicolumn{2}{l}{ Sumber: SK Gubernur DKI Jakarta Nomor 2359/1987 tentang Tanaman yang Dilindungi }
\end{tabular}

\subsubsection{Analisis}

Analisis pada penelitian ini dilakukan dengan memberikan penilaian terhadap tingkat keragaman spesies dan fungsi ekologis pohon. Metode analisis yāng digunakan yaitu analisis kuantitatif-deskriptif.

\subsubsection{Penilaian Tingkat Keragaman Spesies Pohon}

Pada tahap ini, penilaian dilakukan untuk menghitung indeks keragaman jēnis pohon pada lanskap Setu Babakan. Menurut Odum (1998), metode yang digunakan di dalam perhitungan tersebut dapat digambarkan melalui penggunaan metode Shannon-Wiener, yaitu :

$\infty$
$\circ$
$\stackrel{0}{\circ}$
$\stackrel{ }{ }$

$$
\mathrm{H}^{\prime}=3.322\left(\log N-\Sigma \frac{N i(\log N i)}{N}\right)
$$

Keterangan :

H'

: Tingkat keragaman

N : Total individu dari seluruh spesies

$\mathrm{N}_{\mathrm{i}} \quad$ : Total individu setiap spesies

3.322

: Faktor konversi

Nilai perhitungan index keragaman (H’) menunjukkan bahwa :

$\mathrm{H}^{\prime}>3 \quad$ : Keragaman spesies tinggi

(1) $>$ '>3 : Keragaman spesies sedang

$\mathrm{H}^{\prime}<1 \quad$ : Keragaman spesies rendah

Penilaian terhadap tingkat keragaman spesies pohon dilakukan pada dua jenis tapak, yaitu area lingkar Setu Babakan dan sepuluh contoh pekarangan warga. 


\subsubsection{Penilaian Fungsi Ekologis Individu Pohon}

Tahapan ini dilakukan untuk mengetahui nilai secara kuantitatif dan deskriptif keberadaan vegetasi pohon, sehingga diperoleh tingkat kenyamanan bagi pengguna berdasarkan fungsi ekologis pohon sebagai pemodifikasi suhu, pengontrol kelembaban udara, peredam kebisingan, penahan angin, serta habitat bagi kehadiran satwa (burung).

Berdasarkan Hidayat (2008), teknik penilaian fungsi ekologis dilakukan berdasarkan komponen fungsi ekologis vegetasi pohon pada tapak. Rumus yang digunakan untuk dapat menentukan kriteria tersebut adalah sebagai berikut :

KPI $=\frac{\text { Jumlah masing-masing kriteria penilaian }}{\text { Jumlah ideal (total maksimum)masing-masing kriteria }}$

KPI : Key Performance Index

Terdapat empat kategori penilaian (sangat baik, baik, kurang baik, dan buruk) yang diberikan pada masing-masing spesies melalui kriteria fungsi yang điberikan, dalam penelitian ini yaitu sebanyak tiga kriteria dari ciri morfologis terbaik pohon yang sesuai dengan fungsinya. Menurut Hidayat (2008), nilai atau skor yang paling sempurna adalah sebesar 100\% apabila masing-masing kriteria füngsi memenuhi penilaian paling sempurna dari akumulasi. Apabila skor kurang dari 40\%, maka suatu spesies pada fungsi ekologis pohon tertentu akan tergolong ke dalam kategori rendah. Presentase pembobotan dengan tujuan untuk menaikkan kriteria adalah sebagai berikut :
4 : Sangat baik
(bila pemenuhan kriteria $\geq 81 \%$ )
3 : Baik
(bila pemenuhan kriteria 61-80\%)
2 : Kurang baik
(bila pemenuhan kriteria 41-60\%)
$1:$ Buruk
(bila pemenuhan kriteria $\leq 40 \%$ )

(Hidayat 2008)

Pengelompokan fungsi vegetasi dilakukan dengan menggunakan standar dan dasar penilaian berupa kriteria seperti pada Tabel 4 .

Tabel 4. Variabel Fungsi Ekologis dan Kriteria Penilaian

\begin{tabular}{cl}
\multicolumn{1}{c}{ Variabel } & \multicolumn{1}{c}{ Kriteria Penilaian } \\
\hline Modifikasi Suhu & Percabangan 2 meter di atas tanah (Peraturan Menteri \\
sebagai Penaung & Pekerjaan Umum Nomor: 05/PRT/M/2008) \\
& Berkanopi besar dan lebar (Booth dan Hiss 2005) \\
\hline
\end{tabular}


Tabel 4. Variabel Fungsi Ekologis dan Kriteria Penilaian (Lanjutan)

\begin{tabular}{|c|c|c|}
\hline & Variabel & Kriteria Penilaian \\
\hline & & $\begin{array}{l}\text { Bermassa daun padat (Peraturan Menteri Pekerjaan } \\
\text { Umum Nomor: 05/PRT/M/2008) }\end{array}$ \\
\hline & Kontrol & Pola percabangan horizontal (Grey dan Deneke 1978) \\
\hline & Kelembabana & Berdaun jarum (Grey dan Deneke 1978) \\
\hline & Udara & Kerapatan daun rendah (Bianpoen et al. 1989) \\
\hline & & Tajuk rapat dan massa daun rapat (Dirjen \\
\hline & Peredam & Binamarga 1996) \\
\hline & Kobicingan & Struktur cabang dan batang besar (Grey dan Deneke \\
\hline & & 1978) \\
\hline & & Daun tebal dan tajuk rindang (Grey dan Deneke 1978) \\
\hline "ृँ & & Tajuk massif dan rindang (YAI dan BAPPEDA DKI \\
\hline & Ponshan Angin & 2001) \\
\hline & Penanan Angin & Dahan yang kuat tapi cukup lentur (Dahlan 1992) \\
\hline$=$ & & Vegetasi tinggi (Carpenter 1975) \\
\hline 0 & & Memiliki nektar dan bunga (Hernowo dan Prasetyo \\
\hline & & 1989) \\
\hline & Kellaumdil Salwd & Jenis pohon berbuah (Hernowo dan Prasetyo 1989) \\
\hline E & & Memiliki bentuk batang yang menarik (Hernowo dan \\
\hline 0 & & Prasetyo 1989) \\
\hline
\end{tabular}

\subsubsection{Rekomendasi}

Perumusan rekomendasi dilakukan berdasarkan hasil analisis yang dilakukan terhadap penilaian fungsi ekologis pohon serta rekomendasi secara deskriptif berdasarkan kondisi dari eksisting kawasan. Rumusan rekomendasi untuk fungsi ekologis pohon yaitu berupa peta komposit dari hasil analisis sebaran lima aspek penilaian, yang selanjutnya diberikan rekomendasi untuk memperoleh manfaat secara maksimum bagi pengunjung Setu Babakan. Selain itu, memberikan rekomendasi bagi fasilitas-fasilitas dan program wisata yang masih belum terlihat pada kawasan berupa ilustrasi yang berfungsi untuk memaparkan kondisi atau perbaikan yang dapat dilakukan. 


\section{BAB IV \\ KONDISI UMUM}

\subsection{Sejarah}

Perkampungan Budaya Betawi Setu Babakan merupakan sebuah kawasan yang ditetapkan oleh pemerintah Jakarta sebagai lokasi pelestarian dan pengembangan budaya Betawi secara berkesinambungan. Sebagian besar penduduknya adalah orang Betawi asli yang secara turun temurun tinggal di đaerah tersebut, sedangkan sebagian kecil merupakan para pendatang yang sudah ținggal lebih dari 30 tahun di daerah ini. Kawasan yang mengusung konsep kampung wisata ini terdiri dari area pemukiman warga dengan desain rumahrümah Betawi melalui pola-pola ukiran pada fasad bangunannya, objek dan kegiatan agrowisata, perdagangan (rumah makan dan toko cenderamata) sebagai penunjang ekonomi warga, serta berbagai fasilitas rekreasi yang disediakan bagi pengunjung Setu Babakan. Aktivitas wisata yang disuguhkan cenderung beragam. Konsep yang diusung tidak terlepas dari nilai budaya Betawi yang saling berkesinambungan dengan kegiatan masyarakat di dalam kawasan.

Setu Babakan diresmikan pada tahun 2004 melalui SK Gubernur No. 9 Tahun 2000, sebagai sebuah kawasan Cagar Budaya, bersamaan dengan peringatan HUT DKI Jakarta ke-474. Kawasan ini dianggap masih melestarikan nilai-nilai budaya khas Betawi, seperti bangunan, dialek bahasa, seni tari, seni musik, dan seni drama. Perkampungan Budaya Betawi Setu Babakan ini juga pernah menjadi lokasi kunjungan wisata para peserta konferensi PATA (Pasific Asia Travel Association) di Jakarta pada bulan Oktober 2002. Penetapan Setu Babakan sebagai Cagar Budaya Betawi telah direncanakan sejak tahun 1996. (Kawasan seperti Condet, Jakarta Timur, juga sempat direncanakan sebagai cagar budaya. Akan tetapi seiring berkembangnya waktu, nuansa budaya Betawi kawasan tersebut semakin luntur sehingga rencana penetapan cagar budaya urung dilaksanakan. 


\subsection{Letak, Luas, dan Aksesibilitas}

Perkampungan Budaya Betawi Setu Babakan secara administratif terdiri dari dua kawasan utama, yaitu kawasan yang dimiliki oleh Pemda DKI Jakarta dan kawasan atas kepemilikan pribadi. Kawasan yang dimiliki oleh Pemda DKI meliputi area lingkar Setu Babakan dengan lebar jalan yang dibatasi oleh jalur pedestrian dan saluran pembuangan air atau gorong-gorong, sedangkan lahan kepemilikan pribadi digunakan sebagai pemukiman, fasilitas publik, dan halaman kantor. Wilayah ini dibatasi oleh empat kelurahan besar, yaitu Kelurahan fagakarsa di bagian utara, Kelurahan Kalisari di bagian timur, Kelurahan Şrengsengsawah di bagian selatan, dan Kelurahan Ciganjur di bagian barat. Perkampungan Budaya Betawi memiliki luas \pm 289 ha, sedangkan luas danau Setu Babakan sebesar 27 ha (Laporan SLHD Provinsi DKI Jakarta 2011).

Untuk memasuki kawasan rekreasi Setu Babakan, dapat melalui dua pintu Utama, gerbang pertama yaitu gerbang Si Pitung di sebelah barat yang berbatasan fangsung dengan Jalan Mohammad Kafi 2. Pada jalan tersebut mudah ditemui berbagai angkutan umum dari mulai angkot yang menghubungkan langsung ke arah Depok hingga mikrolet yang melewati dua stasiun terdekat seperti Stasiun Eenteng Agung dan Tanjung Barat. Melalui gerbang utama ini pengunjung dapat secara langsung dan memiliki akses yang lebih dekat untuk dapat berkunjung ke kantor informasi dan area pentas budaya. Gerbang kedua pada bagian selatan merupakan pintu alternatif yang juga berbatasan langsung dengan jalur jalan publik, sekaligus sebagai jalan batas provinsi DKI Jakarta dengan Kotamadya Depok (Gambar 3). Kondisi umum dari kawasan Perkampungan Budaya Betawi Setu Babakan dapat dilihat pada Gambar 4.

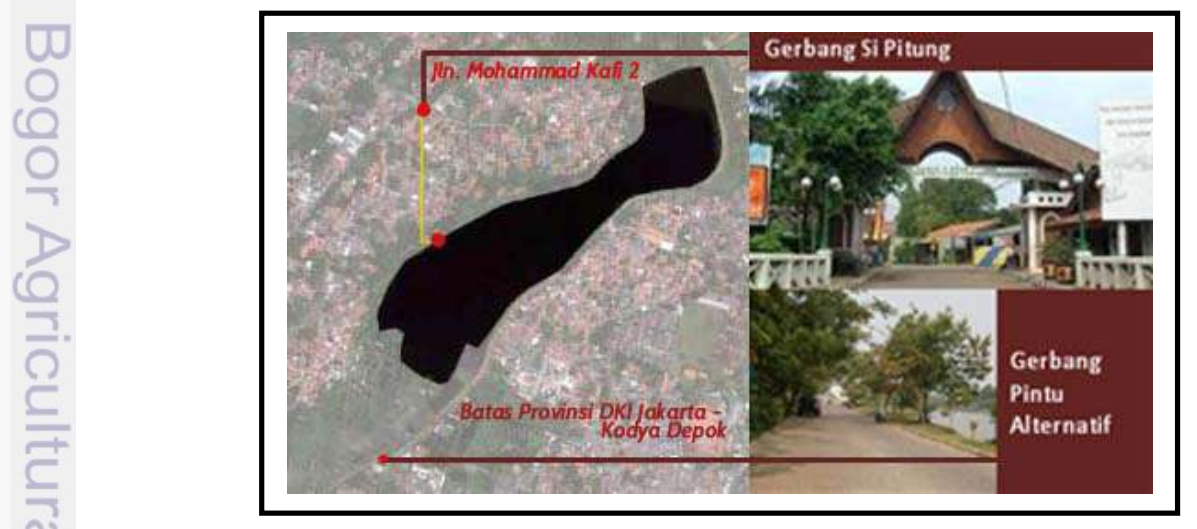

Gambar 3. Akses masuk kawasan rekreasi Setu Babakan 


\subsection{Klimatologi}

Berdasarkan data iklim yang diperoleh dari Stasiun Klimatologi Pondok Betung Ciledung, Tangerang tiga tahun terakhir, rata-rata suhu terendah berada pada tahun 2010 sebesar $27.6^{\circ} \mathrm{C}$. Suhu minimum $22.90^{\circ} \mathrm{C}$ pada tahun 2009, sedangkan suhu tertinggi berada pada tahun yang sama $35.8^{\circ} \mathrm{C}$. Curah hujan ratarata tertinggi berada pada tahun 2010, $244.04 \mathrm{~mm}$ per bulannya. Nilai tertinggi berada pada bulan Oktober tahun 2010 yaitu 518 mm, sedangkan terendah sebesar $\overline{\overline{49}} .30 \mathrm{~mm}$ di bulan Oktober tahun 2011. Menurut Rafi’i (1995), terdapat tiga kriteria iklim berdasarkan klasifikasi yang diberikan oleh Schmidt-Ferguson, yaitu bulan basah (curah hujan dalam satu tahun $>100 \mathrm{~mm} / \mathrm{bulan}$ ), bulan lembab (curah hüjan dalam satu tahun 60-100 mm/bulan), dan bulan kering (curah hujan dalam satu tahun $<60 \mathrm{~mm} /$ bulan). Berdasarkan data iklim yang diperoleh tiga tahun terakhir, rata-rata curah hujan dalam satu tahun adalah 174.86 mm/bulan. Nilai tersebut menunjukkan bahwa kawasan Perkampungan Budaya Betawi Setu Babakan tergolong dalam kriteria iklim bulan basah. Rata-rata kelembaban udara tẹrtinggi berada pada tahun 2010, yaitu 85\%, kelembaban udara terendah 69\% (September 2011) dan tertinggi 96\% (2009). Rata-rata kecepatan angin tertinggi berada pada tahun 2010, yaitu 9 Knot, kecepatan angin terendah 2 Knot (Januari, Februari, April, Mei, Juni, Agustus, September, November 2011) dan tertinggi 12 Knot (April, Agustus, Desember 2010). Data iklim terkait Perkampungan Budaya Betawi Setu Babakan yang berasal dari Stasiun Klimatologi Pondok Betung dapat dilihat pada Tabel 5 .

Tabel 5. Data Iklim Perkampungan Budaya Betawi Setu Babakan

\begin{tabular}{lccc}
\hline \multirow{2}{*}{ Parameter (Per Bulan) } & \multicolumn{3}{c}{ Nilai } \\
\cline { 2 - 4 } & 2009 & 2010 & 2011 \\
Suhu Udara $\left({ }^{\circ} \mathrm{C}\right)$ & 28.00 & 27.60 & 27.75 \\
Rata-rata & 22.90 & 26.80 & 26.80 \\
Minimum & 35.80 & 28.80 & 28.60 \\
\hline Maksimum & & & \\
\hline Eurah hujan (mm) & 191.21 & 244.04 & 89.34 \\
Rata-rata & - & 111.10 & 49.30 \\
Minimum & - & 518.00 & 186.20 \\
Maksimum & & & \\
\hline Kelembaban Udara (\%) & 77 & 85 & 78 \\
\hline Rata-rata & &
\end{tabular}


Tabel 5. Data Iklim Perkampungan Budaya Betawi Setu Babakan (Lanjutan)

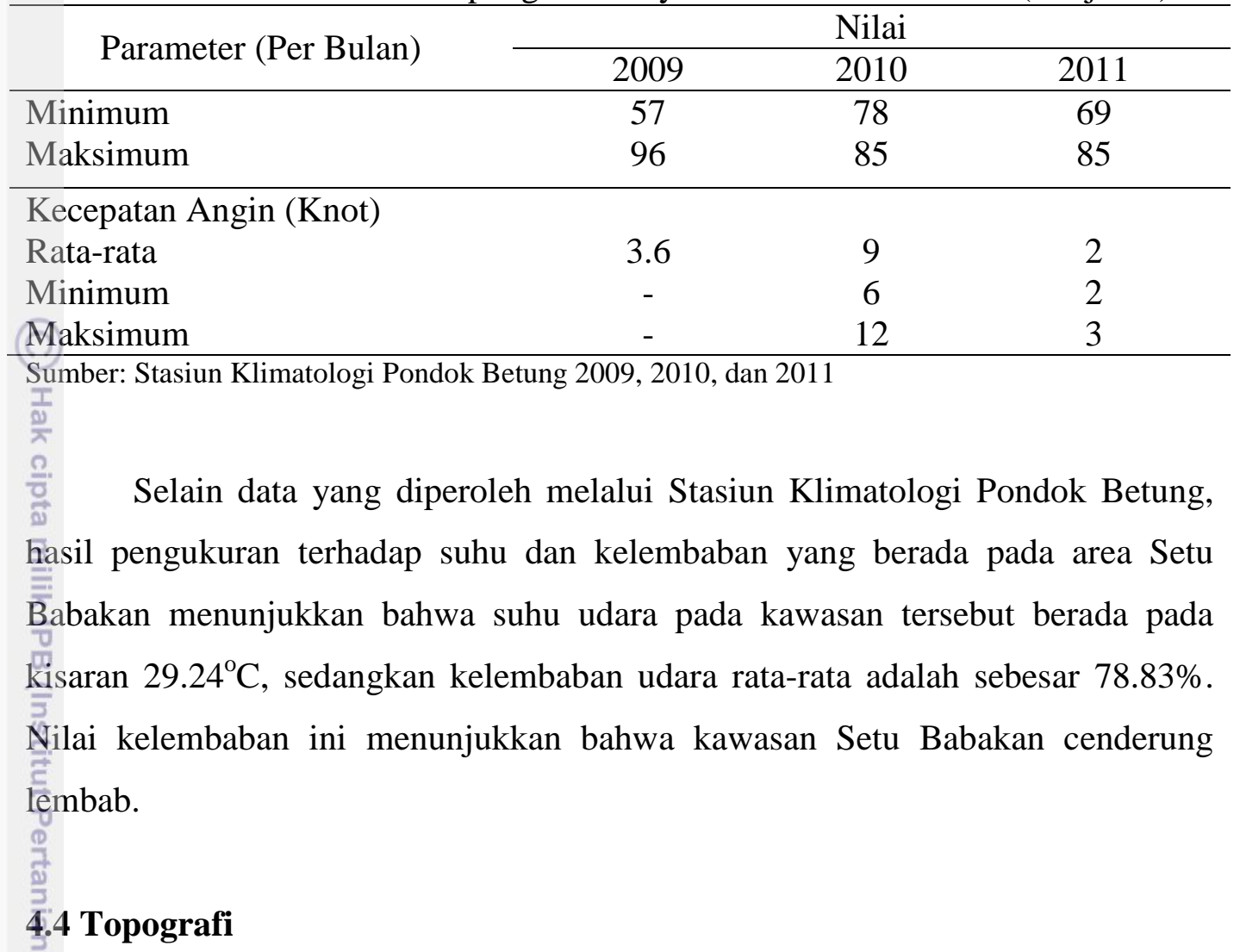

Kondisi topografi di kawasan Setu Babakan tergolong ke dalam topografi đengan kategori sedikit bergelombang dan agak rata. Kemiringan lereng mencapai 8-15\% dengan ketinggian 25 m dpl. Hal ini dapat menunjukkan bahwa kontur alam dan geologis Perkampungan Budaya Betawi Setu Babakan relatif sama. Air tanahnya cukup baik. Sebagian besar penduduk sekitar menggunakan sumber air tanah yang diperoleh dari sumur guna memenuhi kebutuhan hidup sehari-hari. Ketinggian air tanah berada pada kisaran 3-6 m yang merata pada hampir seluruh daerah (Wardiningsih 2005).

\subsection{Kondisi Tanah}

Sifat fisik tanah di Setu Babakan secara umum memliki daya dukung sedang hingga baik, berupa dataran hasil sedimentasi dari tekstur sedang, berat kadar liat lebih $60 \%$ dengan sikma tanah $0.6-0.8 \mathrm{~kg} / \mathrm{cm}^{2}$ serta daya infiltrasinya tergolong lambat hingga sedang. Kawasan ini memiliki derajat kemasaman tanah yang agak masam $\left(\mathrm{pH}, \mathrm{H}_{2} \mathrm{O}\right.$ 6.0-7.5) dan bahan organik dengan kadar rendah hingga sedang (1-3\%) pada lapisan atas, daya absorpsi sedang hingga rendah, 
makin tua bahan induk, makin merah warnanya, makin rendah permeabilitas sedang-tinggi dengan kepekaan tanah terhadap erosi kecil (Direktorat Geologi, 1969)

Berdasarkan sifat kimianya, air tanah di Setu Babakan memiliki kemasaman tanah yang bersifat agak asam ( $\mathrm{pH}, \mathrm{H}_{2} \mathrm{O}$ 4.5-6.0), dengan bahan organik yang tergolong rendah $( \pm 2 \%)$ dan absorbsi tanah menurun ke bawah termasuk sedang (15-30 m), makin ke bawah meningkat. Sifat fisik tanah kurang sesuai, berada pada kisaran sedang-baik dengan kandungan zat organik dan unsur hara yang rendah (3-10\%), kedalaman efektif-dangkal (Wardiningsih 2005).

Kondisi geologi danau dari endapan Pleistocenae dan geologi daratan merupakan endapan dari alluvium. Batuan terdiri dari vulkanik muda yang tẹrsusun oleh lempung tufa, pasir tufa, konglomerat dan endapan lahar. Pelapukan đalam semakin ke selatan butir semakin besar dan lereng-lereng semakin stabil, kelulusan semakin tinggi dan air tanah semakin dalam.

\subsection{Hidrologi}

Setu Babakan sebagai sumber mata air dari Perkampungan Budaya Betawi têrdiri dari empat mata air yang berasal dari Sungai Pitara, Setu Mangga Bolong, Kali Baru Barat, dan Kali Cabang Tengah. Berdasarkan Laporan Status Lingkungan Hidup Daerah Provinsi DKI Jakarta (2011), kondisi setu terawat baik, meskipun ditemukan sampah pada pinggir danau. Setu tergolong alami, perairan hijau, jernih, dan bersih, sebagian areanya ditumbuhi tanaman air. Selain itu, setu aman dari pendangkalan atau erosi karena diberi tanggul tembok. Fungsi perairannya yaitu untuk menampung air hujan, sebagai resapan air, irigasi, rekreasi dan penanggulangan banjir, budi daya ikan, serta sarana olah raga dan crekreasi. Limbah domestik pada inlet untuk kandungan oksigen biologi BOD (Biochemical Oxygen Demand) Setu Babakan memiliki nilai 12.13 mg/l, pada badan air sebesar $10.51 \mathrm{mg} / \mathrm{l}$ (golongan C, sesuai untuk kegiatan perikanan), dan outlet $9.34 \mathrm{mg} / \mathrm{l}$ (golongan B, sesuai untuk air yang dapat diolah bagi kebutuhan Fumah tangga). Inlet untuk kebutuhan kimiawi oksigen (Chemical Oxygen Demand) Setu Babakan memiliki nilai kurang dari 40 mg/l, pada badan air 48.89 
mg/l, dan outlet kurang dari 40 mg/l (golongan D, sesuai untuk pertanian dan lalu lintas air).

Berdasarkan Laporan Status Lingkungan Hidup Daerah Provinsi DKI Jakarta (2011), suhu perairan di Setu Babakan adalah $30.7^{\circ} \mathrm{C}$ pada inlet, $30.7^{\circ} \mathrm{C}$ pada badan air, dan $31.50^{\circ} \mathrm{C}$ pada outlet. Kondisi tersebut masih mampu mendukung kehidupan organisme akuatik karena menurut Boyd (1990), ikan akan tumbuh dengan baik pada kisaran suhu $25-32^{\circ} \mathrm{C}$. Berdasarkan PP No. 82 Tahun 2001 tentang baku mutu air golongan III dan IV, suhu pada kisaran $24-31^{\circ} \mathrm{C}$ masih sesuai untuk kegiatan perikanan dan pertanian.

(i)

\subsection{Vegetasi dan Satwa}

Berdasarkan data dari Dinas Pertanian dan Kehutanan Provinsi DKI Jakarta Tahun 2009, hutan kota Setu Babakan memiliki luas sebesar 3 ha. Setu Babakan dikelilingi oleh deretan pepohonan yang ditanam oleh Pemda DKI Jakarta. Beberapa di antaranya merupakan pohon buah produksi yang juga menjadi ikon kota Jakarta. Adapun rencana penanaman 29 jenis tanaman oleh Pemda DKI didasarkan oleh Keputusan Gubernur DKI Nomor 2359 tentang tạnaman yang dilindungi. Hingga per tahun 2006, sebanyak 16 jenis tanaman telah ditanam. Jumlah pohon yang terdapat di dalam perencanaan penanaman adalah sebanyak 250 pohon yang terbagi menjadi dua, yaitu tanaman buah (bisbol, buah nona, duku condet, durian sitokong, gandaria) dan tanaman penunjang ekonomi (rambutan, melinjo, kecapi, belimbing).

Terdapat berbagai macam jenis satwa yang berada di kawasan Setu Babakan. Jenis yang dapat ditemukan antara lain burung, kupu-kupu, hewan air (ikan dan kepiting), amphibi (katak), dan serangga pohon. Satwa yang hidup di (sekitar kawasan Setu Babakan merupakan satwa cosmopolitan, dapat dijumpai di berbagai tempat, sehingga tidak terdapat satwa langka yang dilindungi oleh undang-undang. Burung tergolong ke dalam salah satu jenis satwa yang beragam yang hidup di kawasan Setu Babakan. Berdasarkan data dari Dinas Pertamanan dan Pemakaman DKI Jakarta, terdapat 16 jenis burung yang beraktivitas di dalam kawasan ini. Jenis-jenis tersebut dapat dilihat pada Tabel 6. 
Tabel 6. Daftar Jenis Burung Di Kawasan Setu Babakan

\begin{tabular}{|c|c|c|c|}
\hline No & Nama Lokal & Nama Latin & Status \\
\hline 1 & Kuntul kecil & Egretta garzetta & \\
\hline 2 & Tekukur biasa & Streptopelia chinensis & \\
\hline 3 & Walet linchi & Collocalia linchi & \\
\hline 4 & Raja udang meninting & Alcedo meninting & \\
\hline 5 & Caladi ulam & Dendrocopus macei & \\
\hline 6 & Layang-layang batu & Hirundo tahitica & \\
\hline 07 & Cipoh kacat & Aegithina tiphia & \\
\hline 8 & Cucak kutilang & Pycnonotus aurigaster & \\
\hline 9 & Merbah cerukcuk & Pycnonotus goiavier & \\
\hline 10 & Cinenen pisang & Orthotomus sutorius & \\
\hline 11 & Cinenen jawa & Orthotomus sepium & Endemik \\
\hline 312 & Kekep babi & Arthamus leucorhynchus & \\
\hline 13 & Cabai jawa & Dicaeum trochileum & Endemik \\
\hline 74 & Bondol jawa & Lonchura leucogastroides & Endemik \\
\hline 마다 & Bondol peking & Lonchura punctulata & \\
\hline 16 & Burung gereja erasia & Passer montanus & \\
\hline
\end{tabular}

Sumber: Dinas Pemakaman dan Pertamanan DKI Jakarta 2011

Kehadiran burung sangat erat kaitannya dengan keberadaan pohon di đalam sebuah kawasan. Burung menggunakan pohon pada jenis-jenis tertentu untuk melakukan aktivitas seperti makan, berkembang biak, beristirahat, dan membuat sarang. Tabel 7 berisi informasi yang menjelaskan mengenai jenis-jenis burung yang terdapat di dalam lingkungan Perkampungan Budaya Betawi Setu Babakan beserta jenis-jenis pohon terkait dari masing-masing jenisnya.

Tabel 7. Burung dan Jenis Pohon yang Disukai

\begin{tabular}{|c|c|c|c|c|}
\hline $\begin{array}{l}\text { Nama } \\
\text { Lokal }\end{array}$ & Nama Latin & $\begin{array}{l}\text { Data } \\
\text { DPP DKI } \\
\text { Jakarta }\end{array}$ & $\begin{array}{l}\text { Data } \\
\text { Primer } \\
\text { (Lapang) }\end{array}$ & Keterangan Pohon \\
\hline $\begin{array}{l}\text { Kuntul } \\
\text { kecil }\end{array}$ & Egretta garzetta & $v$ & & - \\
\hline$\frac{10}{7}$ & & & & $\begin{array}{l}\text { Berbagai jenis rumput, berbagai jenis } \\
\text { pohon palem termasuk kelapa, dan }\end{array}$ \\
\hline $\begin{array}{l}\text { Tekukur } \\
\text { biasa } \\
\frac{\overline{7}}{\mathrm{C}} \text {. }\end{array}$ & $\begin{array}{l}\text { Streptopelia } \\
\text { chinensis }\end{array}$ & $v$ & $v$ & $\begin{array}{l}\text { pisang-pisangan (materi sarang); pohon } \\
\text { asam, tanjung, sawo kecik, durian, dan } \\
\text { berbagai jenis bambu (tempat } \\
\text { berlindung dan menempatkan sarang) }\end{array}$ \\
\hline $\begin{array}{l}\text { Walet } \\
\text { linchi }\end{array}$ & $\begin{array}{l}\text { Collocalia } \\
\text { linchi }\end{array}$ & v & v & - \\
\hline $\begin{array}{l}\text { Raja } \\
\text { udang } \\
\text { meninting }\end{array}$ & $\begin{array}{l}\text { Alcedo } \\
\text { meninting }\end{array}$ & v & & - \\
\hline
\end{tabular}


Tabel 6. Burung dan Jenis Pohon yang Disukai (Lanjutan)

\begin{tabular}{|c|c|c|c|c|}
\hline $\begin{array}{l}\text { Nama } \\
\text { Lokal }\end{array}$ & Nama Latin & $\begin{array}{l}\text { Data } \\
\text { DPP DKI } \\
\text { Jakarta }\end{array}$ & $\begin{array}{c}\text { Data } \\
\text { Primer } \\
\text { (Lapang) }\end{array}$ & Keterangan Pohon \\
\hline $\begin{array}{l}\text { Caladi } \\
\text { ulam }\end{array}$ & $\begin{array}{l}\text { Dendrocopus } \\
\text { macei }\end{array}$ & v & & $\begin{array}{l}\text { Ki hujan (Samanea saman), dadap } \\
\text { (Erythrina lithosperma) }\end{array}$ \\
\hline $\begin{array}{l}\text { Layang- } \\
\text { layang } \\
\text { batu }\end{array}$ & $\begin{array}{l}\text { Hirundo } \\
\text { tahitica }\end{array}$ & v & & - \\
\hline $\begin{array}{l}\text { (O) } \\
\text { Gipoh } \\
\text { kacat } \\
\frac{\text { à }}{0}\end{array}$ & Aegithina tiphia & v & & $\begin{array}{l}\text { Pohon nangka, sirsat, sengon, gamal } \\
\text { (Gliricidia sepium), kenanga (Cananga } \\
\text { odorata), dan kembang kecrutan } \\
\text { (Spathodea campanulata) mengundang } \\
\text { berbagai jenis serangga yang digemari } \\
\text { burung-burung pemakan serangga }\end{array}$ \\
\hline $\begin{array}{l}\text { Gucak } \\
\text { kutilang } \\
\text { ๘o }\end{array}$ & $\begin{array}{l}\text { Pycnonotus } \\
\text { aurigaster }\end{array}$ & v & v & $\begin{array}{l}\text { Beringin (Ficus sp.), kersen ( Muntingia } \\
\text { calabura), salam (Syzygium } \\
\text { polyanthum), buni (Antidesma bunius), } \\
\text { dadap (Erythrina lithosperma) }\end{array}$ \\
\hline $\begin{array}{l}\text { Merbah } \\
\text { cerukcuk }\end{array}$ & $\begin{array}{l}\text { Pycnonotus } \\
\text { goiavier }\end{array}$ & v & v & $\begin{array}{l}\text { Beringin (Ficus sp.), kersen ( Muntingia } \\
\text { calabura), salam (Syzygium } \\
\text { polyanthum), buni (Antidesma bunius) }\end{array}$ \\
\hline $\begin{array}{l}\frac{1}{7} \\
\frac{7}{3} \\
\frac{9}{3} \\
\text { Ginenen } \\
\text { pissang } \\
\text { ji }\end{array}$ & $\begin{array}{l}\text { Orthotomus } \\
\text { sutorius }\end{array}$ & v & & $\begin{array}{l}\text { Randu alas (Bombax malabaricum), } \\
\text { berbagai jenis dadap (Erythrina spp.), } \\
\text { turi (Sesbania grandiflora), janti } \\
\text { (Sesbania sesban), kaliandra (Caliandra } \\
\text { calothyrsus), pohon kupu-kupu } \\
\text { (Bauhinia variegate), dan bahkan } \\
\text { hampir semua jenis tanaman yang } \\
\text { memiliki bunga berbentuk terompet, } \\
\text { teruma yang berwarna merah, kuning, } \\
\text { dan biru. }\end{array}$ \\
\hline $\begin{array}{l}\text { Cinenen } \\
\text { jawa }\end{array}$ & $\begin{array}{l}\text { Orthotomus } \\
\text { sepium }\end{array}$ & v & & $\begin{array}{l}\text { Randu alas (Bombax malabaricum), } \\
\text { berbagai jenis dadap (Erythrina spp.), } \\
\text { turi (Sesbania grandiflora), janti } \\
\text { (Sesbania sesban), kaliandra (Caliandra } \\
\text { calothyrsus), pohon kupu-kupu } \\
\text { (Bauhinia variegate), dan bahkan } \\
\text { hampir semua jenis tanaman yang } \\
\text { memiliki bunga berbentuk terompet, } \\
\text { teruma yang berwarna merah, kuning, } \\
\text { dan biru. }\end{array}$ \\
\hline $\begin{array}{l}\text { Kekep } \\
\text { babi }\end{array}$ & $\begin{array}{l}\text { Arthamus } \\
\text { leucorhynchus }\end{array}$ & v & & - \\
\hline $\begin{array}{l}\text { Gabai } \\
\text { jawa }\end{array}$ & $\begin{array}{l}\text { Dicaeum } \\
\text { trochileum }\end{array}$ & v & v & $\begin{array}{l}\text { Beringin (Ficus sp.), kersen ( Muntingia } \\
\text { calabura), salam (Syzygium } \\
\text { polyanthum), buni (Antidesma bunius) }\end{array}$ \\
\hline Bondol & $\begin{array}{l}\text { Lonchura } \\
\text { leucogastroides }\end{array}$ & v & & $\begin{array}{l}\text { Jambu air semarang (Syzygium } \\
\text { samarangense) untuk digunakan sebagai } \\
\text { sarang }\end{array}$ \\
\hline $\begin{array}{l}\text { Bondol } \\
\text { peking }\end{array}$ & $\begin{array}{l}\text { Lonchura } \\
\text { punctulata }\end{array}$ & v & & $\begin{array}{l}\text { Pinang (Areca catechu) atau palma } \\
\text { lainnya untuk digunakan sebagai sarang }\end{array}$ \\
\hline
\end{tabular}


Tabel 7. Burung dan Jenis Pohon yang Disukai (Lanjutan)

\begin{tabular}{|c|c|c|c|c|}
\hline $\begin{array}{l}\text { Nama } \\
\text { Lokal }\end{array}$ & Nama Latin & $\begin{array}{c}\text { Data } \\
\text { Sekunder }\end{array}$ & $\begin{array}{c}\text { Data } \\
\text { Primer } \\
\text { (Lapang) }\end{array}$ & Keterangan Pohon \\
\hline $\begin{array}{l}\text { Burung } \\
\text { gereja } \\
\text { erasia }\end{array}$ & $\begin{array}{l}\text { Passer } \\
\text { montanus }\end{array}$ & v & $v$ & $\begin{array}{l}\text { Pohon kupu-kupu (makan), jambu air } \\
\text { (berteduh), rambutan (bermain), mangga } \\
\text { (bertengger) }\end{array}$ \\
\hline $\begin{array}{l}\text { Wiwik } \\
\text { kelabu }\end{array}$ & $\begin{array}{l}\text { Cacomantis } \\
\text { merulinus }\end{array}$ & & $v$ & - \\
\hline 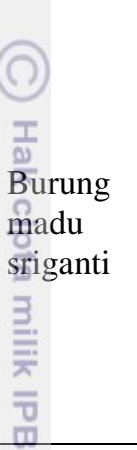 & $\begin{array}{l}\text { Nectarinia } \\
\text { jugularis }\end{array}$ & & v & $\begin{array}{l}\text { Mengkudu (Morinda citrifolia), buah } \\
\text { benalu (Loranthus sp)., randu alas } \\
\text { (Bombax malabaricum), berbagai jenis } \\
\text { dadap (Erythrina spp.), turi (Sesbania } \\
\text { grandiflora), janti (Sesbania sesban), } \\
\text { kaliandra (Caliandra calothyrsus), } \\
\text { pohon kupu-kupu (Bauhinia variegate), } \\
\text { dan bahkan hampir semua jenis tanaman } \\
\text { yang memiliki bunga berbentuk } \\
\text { terompet, teruma yang berwarna merah, } \\
\text { kuning, dan biru. }\end{array}$ \\
\hline
\end{tabular}
(2012), Finchmania (2012), dan Siregar (2012) (data diolah)

\subsection{Sosial}

Pada tahun 2011, Perkampungan Budaya Betawi Setu Babakan terdiri dari minasyarakat yang berprofesi sebagai karyawan swasta (20\%), petani (3.8\%), pedagang (6.4\%), buruh (3.2\%), PNS (3.1\%), TNI/Polri (0.4\%), pensiunan (1.8\%), wiraswasta (0.9\%), dan belum produktif (60.4\%). Berdasarkan Moechtar, Sarwadana, dan Semarajaya (2012), 93\% masyarakat masih tetap melestarikan budaya Betawi dan 90\% aktivitas yang mereka lakukan masih memiliki ciri khas budaya Betawi. Budaya masyarakat kawasan Perkampungan Budaya Betawi Setu Babakan banyak terpengaruh oleh sistem kepercayaan agama Islam, sebegai agama yang paling banyak dianut oleh masyarakatnya (88.8\%). Faktor yang mendukung terbentuknya pola permukiman adalah sosial budaya yang berbasis (Islam. Elemen sosial budaya yang dapat ditemukan antara lain seni musik dan tari (Tari Topeng), teater tradisional (Topeng Betawi), Silat Betawi (BEKSI), ondelondel, budidaya ikan keramba, pembuatan bir pletok, hadroh (pertunjukan musik yang kental dengan agama Islam), prosesi pernikahan adat Betawi, sunatan, akekah (acara potong kambing untuk anak yang baru lahir), injak tanah (prosesi anak yang baru bisa belajar jalan), dan ngederes (membaca Al-Quran bersamasama dengan masyarakat). 
Moechtar, Sarwadana, dan Semarajaya (2012) menyebutkan bahwa pada kategori ruang berupa permukiman, ditemukan bangunan berupa rumah, warung, mesjid, dan sekolah yang terdiri dari TK, SD, SMP, SMA, dan universitas. Fasilitas berupa elemen keras yang terdapat di dalamnya, yaitu jembatan, undakan, pagar, lampu, jalan setapak, gazebo, dan kolam. Selain permukiman, terdapat kategori ruang berupa kuburan dengan fasilitas berupa jalan setapak dan lampu, serta danau berupa jalan setapak.

플 Pusat area rekreasi Perkampungan Budaya Betawi Setu Babakan berada di dalam lingkar area danau. Di dalamnya terdapat berbagai macam aktivitas yang biasa dilakukan oleh pengunjung, seperti duduk-duduk, menikmati pemandangan, bersantap, menjajakan makanan, bermain fasilitas rekreasi air (sepeda air dan perahu), dan memancing. Sebaran aktivitas tersebut dapat dilihat pada Gambar 5. 


\subsection{Tata Guna Lahan}

Kawasan Perkampungan Budaya Betawi Setu Babakan dibedakan menjadi dua bagian, yaitu area tidak terbangun sebesar $\pm 53.2 \%$ (RTH, kebun campuran, tegalan, tanah kosong, rawa, dan empang) dan kawasan terbangun dengan besar \pm 46.8\% (lahan pemukiman, jasa industri, perdagangan, perkantoran, dan fasilitas umum. Luas dan presentase untuk masing-masing penggunaan lahan dapat dilihat pada Tabel 8.

$\frac{T}{\frac{T}{N}}$

fabel 8. Penggunaan Lahan Perkampungan Budaya Betawi Setu Babakan

\begin{tabular}{|c|c|c|c|c|c|c|}
\hline & \multicolumn{3}{|c|}{ Terbangun } & \multicolumn{3}{|c|}{ Tidak Terbangun } \\
\hline 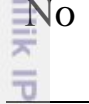 & Jenis Penggunaan & $\begin{array}{l}\text { Luas } \\
(\mathrm{Ha})\end{array}$ & $(\%)$ & Jenis Penggunaan & $\begin{array}{l}\text { Luas } \\
(\mathrm{Ha})\end{array}$ & $(\%)$ \\
\hline ए1 & Pemukiman & 46.86 & 27.4 & Pemakaman (RTH) & 20.79 & 12.6 \\
\hline 2 & $\begin{array}{l}\text { Jasa industri/ } \\
\text { perdagangan }\end{array}$ & 6.6 & 4.0 & Tanah kosong & 15.83 & 10.2 \\
\hline$\stackrel{ᄃ}{=} 3$ & Jalan & 8.58 & 5.2 & Danau & 7.26 & 4.4 \\
\hline 4 & Fasilitas & 15.83 & 10.2 & Kebun campuran & 19.14 & 11.6 \\
\hline 5 & - & - & - & Pekarangan & 23.76 & 14.4 \\
\hline$\frac{1}{20}$ & Jumlah & 77.87 & 46.8 & Jumlah & 86.78 & 53.2 \\
\hline
\end{tabular}

Sumber: Wardiningsih 2005 


\section{BAB V \\ HASIL DAN PEMBAHASAN}

\subsection{Identifikasi Karakteristik RTH Lanskap Setu Babakan}

RTH yang dievaluasi berada pada lahan milik pemerintah daerah berupa jalur jalan bagi pejalan kaki dan pengguna sepeda motor yang mengelilingi danau. Area ini dibatasi oleh gorong-gorong atau saluran pembuangan air yang berjarak $\underset{ \pm}{ \pm} \mathrm{m}$ dari tepi danau. Vegetasi yang diteliti dalam RTH tersebut adalah pohon yang tumbuh pada area pejalan kaki dan area yang berada tepat di pinggir saluran pembuangan.

Jenis pohon yang ditanam pada lingkar Setu Babakan mayoritas terdiri dari pohon-pohon dengan fungsi untuk keseimbangan ekologis kawasan, terlihat pada tajuk serta arsitektur batang dan dahan yang cukup beragam. Pohon-pohon yang berada pada lingkar setu, baik yang berada di tepi danau maupun yang berada di tepi jalan (dekat dengan saluran pembuangan air) merupakan hasil dari program penanaman yang dilakukan oleh Pemda DKI Jakarta. Beberapa jenis pohon yang terdapat di kawasan tersebut belum menunjukkan ketinggian yang m̧aksimal. Hal ini disebabkan oleh penanaman yang bertahap (pohon pada lingkar setu masih merupakan rencana). Pemerintah secara bertahap ingin mewujudkan kondisi RTH kawasan yang tidak saja nyaman, namun juga dipenuhi oleh keragaman jenis vegetasi khasnya. Oleh karena itu akan banyak ditemukan pohonpohon yang belum mencapai ketinggian 2 meter, masih belum kepada pertumbuhan batang yang optimal. Pada area ini tidak terlihat adanya tumbuhan yang difungsikan untuk estetika. Pohon-pohon khas Jakarta pun terlihat berada pada beberapa titik sepanjang lingkar Setu Babakan.

Kondisi fisik dari beberapa tanaman kurang menunjukkan pertumbuhan yang baik, seperti adanya gejala kekeringan pada tanaman tertentu. Pohon mahoni dan bintaro merupakan jenis vegetasi yang menunjukkan pertumbuhan terbaik di dalam kawasan. Pohon yang terlihat tumbuh dengan kurang baik antara lain jati, bungur, dan kawista batu. Faktor yang menyebabkan pertumbuhan kurang maksimal pada suatu individu pohon, yaitu kurangnya penyinaran yang diperoleh 
pohon dengan ketinggian lebih rendah dari pohon-pohon yang ada di sekitarnya dan ketidakcocokan suatu jenis pohon tertentu untuk tumbuh di area lembab.

Perkampungan Budaya Betawi Setu Babakan memiliki potensi akan keragaman hayati berupa tumbuhan yang beberapa di antaranya termasuk dalam tanaman langka yang menjadi tanaman khas kota Jakarta. Beberapa jenis pohon yang berada pada kawasan termasuk ke dalam jenis pohon langka yang tertera pada SK Gubernur DKI Jakarta Nomor: 2359/1987 tentang Tanaman yang Dīindungi. Jenis-jenis tersebut yaitu srikaya (Annona squamosa), buni (Antidesma bunius), bisbul (Diospyros blancoi), kawista batu (Feronia lucida), wikem (Flacourtia rukam), duku condet (Lansium domesticum), mengkudu (Morinda citrifolia), dan jamblang (Syzygium cumini) seperti yang tertera pada Gambar 6. Jenis-jenis pohon yang berada pada area lingkar setu cenderung terdiri $\overline{\bar{d}}$ ari jenis-jenis yang memberikan fungsi ekologis, sedangkan pohon pada area pekarangan lebih berfungsi memberikan nilai produksi, salah satunya yaitu dengan menghasilkan buah.

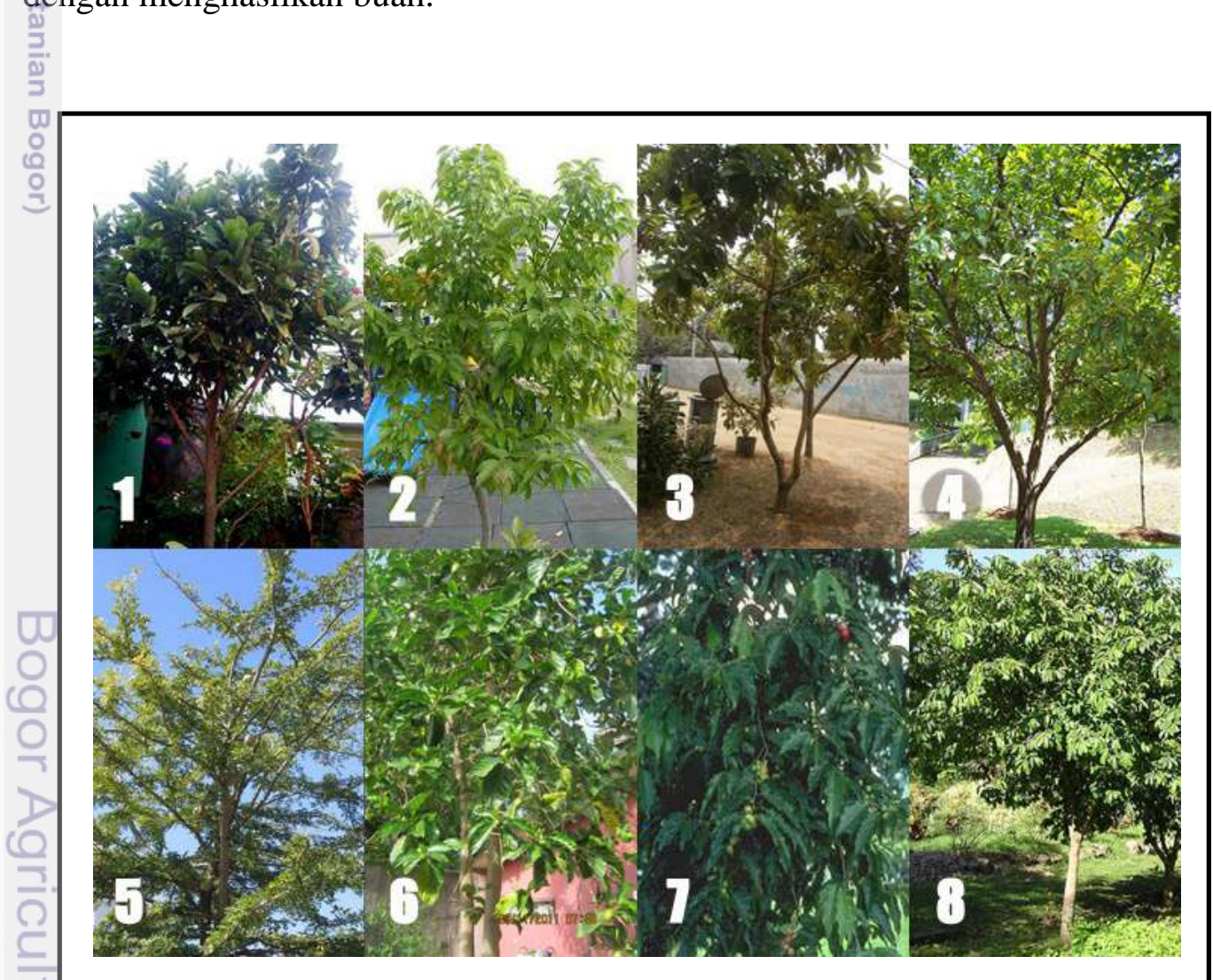

Gambar 6. Pohon langka di Setu Babakan (1) bisbul (2) buni (3) duku condet

(4) jamblang (5) kawista batu (6) mengkudu (7) rukem (8) srikaya 


\subsection{Pengaruh Sosial terhadap RTH Lanskap Setu Babakan}

Secara administratif, status lahan kawasan rekreasi Setu Babakan dimiliki oleh dua pihak, yaitu pemerintah DKI Jakarta pada area sekeliling setu dan kepemilikan pribadi pada area pemukiman, kantor dan tempat ibadah. Hal ini tentunya akan mempengaruhi pengelolaan RTH kawasan mulai dari penanaman awal hingga pemeliharaan ke depannya. Saat ini pengelolaan RTH lingkar danau dilakukan oleh Dinas Pemakaman dan Pertamanan Jakarta Selatan. Oleh karena i⿱亠幺十 dapat dikatakan bahwa jenis-jenis pohon yang telah hidup di sekeliling danau merupakan hasil dari gagasan pemerintah. Adapun pemeliharaan yang dilakukan, seperti pemangkasan tajuk pohon pada periode-periode tertentu, serta pembersihan pohon yang telah tumbang akibat hujan dan petir.

Pengelolaan RTH lingkar danau dilaksanakan oleh pemerintah daerah, namun masyarakat setempat baik penduduk yang tinggal di sekitarnya maupun para pedagang perlu turut berperan. RTH Setu Babakan telah cukup banyak mengalami perubahan dari waktu ke waktu, mulai dari sebuah tatanan RTH èksisting hingga kondisi vegetasi yang ada seperti saat ini melalui rencana penanaman baru Pemda DKI Jakarta. Hal ini dilakukan guna menjaga kelestarian lingkungan setu, baik dari segi ekologis hingga warisan budaya alam. Selain itu, rencana penanaman juga dilakukan guna mengganti pohon-pohon tua yang telah tumbang akibat petir dan hujan. Melihat potensi yang dimiliki RTH kawasan, baik untuk kenyamanan dan kelestarian individu vegetasi, telah menjadi suatu kewajiban utama bagi penduduk setempat untuk memahami dan menjaga kehadiran vegetasi. Konsep sosial-kebudayaan yang dimiliki dan dianut oleh sebagian besar penduduknya, nampaknya telah sekaligus memberikan pengaruh besar terhadap kelestarian RTH ini. Selanjutnya, tugas bagi pengunjung yaitu (senantiasa menjaga dan menghindari tindakan yang merusak vegetasi agar tetap festari dan tumbuh dengan baik.

Hasil wawancara dengan user mengenai perubahan kondisi RTH setelah dilakukan pengelolaan oleh Pemda DKI menunjukkan bahwa, mereka menyatakan Fasa nyaman dan sejuk berada di kawasan yang ditumbuhi pepohonan, serta berpendapat bahwa penataan tata hijau di area setu pun semakin membaik. Selain itu, pengelolaan terhadap kawasan semakin mengarah pada perubahan penanaman 
vegetasi yang lebih baik, seiring dengan semakin menipisnya area perkerasan (bangunan tempat tinggal). Akan tetapi, mereka cukup menyayangkan penanaman pohon yang bukan berjenis pohon buah, seperti bintaro dan mahoni yang banyak tumbuh di lokasi tersebut. Mereka mengharapkan hadirnya jenis-jenis pohon buah seperti rambutan dan mangga yang lebih bersifat produktif dan dapat dikonsumsi. Pada musim panen, pengelola terbiasa membagikan hasil panen dari beberapa pohon yang menghasilkan buah kepada penduduk sekitar, termasuk pedagang ȳang berada di dalam kawasan rekreasi setu, seperti buah rambutan, nangka, melinjo dan kecapi. Mereka juga menyebutkan jenis-jenis pohon pada kawasan Perkampungan Budaya Betawi Setu Babakan yang rata-rata mereka ketahui, yaitu kapuk randu, kecapi, mengkudu, buni, manggis, bohok, dan jengkol. Dari segi rencana RTH untuk konservasi dan edukasi, mereka setuju terhadap adanya penamaan nama lokal dan ilmiah pada masing-masing pohon di lingkar setu.

\subsection{Identifikasi Jenis Pohon pada Tapak}

Sebagai kawasan konservasi, selain kegiatan budaya lokal dan objek arsitektur bangunan yang mengusung konsep pola etnik Betawi, Setu Babakan jêga memiliki jenis-jenis vegetasi khas yang tumbuh di beberapa titik pada area tepi danau. Tidak hanya pada kawasan lingkar danau, beberapa warga juga membudidayakan tanaman-tanaman khas di pekarangan rumah mereka melalui sumbangan bibit yang diberikan oleh Dinas Pertanian dan Kehutanan DKI Jakarta. Ragam tanaman dapat terlihat mulai dari tanaman-tanaman khas itu sendiri hingga tanaman yang telah secara umum ditemukan di berbagai kawasan lain.

Pada Tabel 9 ditunjukkan daftar dari jenis-jenis pohon berdasarkan data primer yang diperoleh melalui pengamatan secara langsung.

Tabel 9. Daftar Jenis-Jenis Pohon Lingkar Setu dan Pekarangan

\begin{tabular}{cllcc} 
No & \multicolumn{1}{c}{ Nama Latin } & \multicolumn{1}{c}{ Nama Lokal } & Lingkar Setu & Pekarangan \\
\hline 1 & Acacia longifolia & Akasia & $\mathrm{v}$ & \\
2 & Adenanthera pavonina & Saga & $\mathrm{v}$ & \\
3 & Annona squamosa & Srikaya & & $\mathrm{v}$ \\
5 & Antidesma bunius & Buni & $\mathrm{v}$ & \\
5 & Areca catechu & Pinang & & $\mathrm{v}$ \\
6 & Artocarpus altilis & Sukun & $\mathrm{v}$ &
\end{tabular}


Tabel 9. Daftar Jenis-Jenis Pohon Lingkar Setu dan Pekarangan (Lanjutan)

\begin{tabular}{|c|c|c|c|c|}
\hline No & Nama Latin & Nama Lokal & Lingkar Setu & Pekarangan \\
\hline 7 & $\begin{array}{l}\text { Artocarpus } \\
\text { heterophyllus }\end{array}$ & Nangka & v & V \\
\hline 8 & Averrhoa carambola & Belimbing & v & v \\
\hline 9 & Azadirachta indica & Mimba & v & \\
\hline 10 & Bauhinia purpurea & Kupu-kupu & v & \\
\hline 11 & Cananga odorata & Kenanga & & v \\
\hline 12 & Ceiba pentandra & Kapuk randu & v & \\
\hline 73 & Cerbera manghas & Bintaro & v & \\
\hline$\overline{1} 14$ & Citrus maxima & Jeruk bali & & v \\
\hline 15 & Crateva religiosa & Sawo duren & v & v \\
\hline 16 & Cocos nucifera & Kelapa & v & \\
\hline 77 & Coryota mitis & Palem ekor ikan & & v \\
\hline 18 & Delonix regia & Flamboyan & v & \\
\hline 19 & Dillenia sp. & Sempur & v & \\
\hline 20 & Dimocarpus longan & Lengkeng & & v \\
\hline 21 & Diospyros blancoi & Bisbul & v & \\
\hline 22 & Durio zibethinus & Durian montong & & v \\
\hline 23 & Erythrina crista-galli & Dadap merah & v & \\
\hline 24 & Eucalyptus deglupta & Rainbow eucalyptus & v & \\
\hline 25 & Feronia lucida & Kawista batu & v & $v$ \\
\hline 26 & Ficus benjamina & Beringin & v & v \\
\hline 27 & Ficus binnendykii & Akar ara & v & \\
\hline 28 & Ficus elastica & Beringin karet & v & \\
\hline 29 & Ficus lyrata & Biola cantik & v & \\
\hline 30 & Filicium decipiens & Kerai payung & v & \\
\hline 31 & Flacourtia rukam & Rukem & & v \\
\hline 32 & Gliricidia sp. & Gamal & v & \\
\hline 33 & Gnetum gnemon & Melinjo & v & v \\
\hline 34 & Hura crepitans & Pohon roda & v & \\
\hline 35 & Lagerstromia speciosa & Bungur & v & \\
\hline 36 & Lansium domesticum & Duku condet & & v \\
\hline 3 & $\begin{array}{l}\text { Leucaena } \\
\text { leucocephala }\end{array}$ & Lamtoro & v & \\
\hline $3 \varepsilon$ & Mangifera indica & Mangga & v & \\
\hline 35 & Mangifera indica & Mangga (apel) & & v \\
\hline 4 & Mangifera indica & $\begin{array}{l}\text { Mangga (arum } \\
\text { manis) }\end{array}$ & & v \\
\hline 41 & Mangifera indica & Mangga (okyong) & & v \\
\hline-42 & Manilkara zapota & Sawo manila (betawi) & & v \\
\hline 43 & Manilkara zapota & Sawo manila (kulon) & & v \\
\hline 44 & Mimusoph elengi & Tanjung & $\mathrm{v}$ & \\
\hline
\end{tabular}


Tabel 9. Daftar Jenis-Jenis Pohon Lingkar Setu dan Pekarangan (Lanjutan)

\begin{tabular}{|c|c|c|c|c|}
\hline No & Nama Latin & Nama Lokal & Lingkar Setu & Pekarangan \\
\hline 45 & Morinda citrifolia & Mengkudu & $\mathrm{v}$ & $\mathrm{v}$ \\
\hline 46 & Muntingia calabura & Kersen & v & \\
\hline 47 & Nephelium lappaceum & Rambutan (aceh) & & v \\
\hline 48 & Nephelium lappaceum & Rambutan (binjai) & & v \\
\hline 49 & Nephelium lappaceum & Rambutan (cimacan) & & v \\
\hline 50 & Nephelium lappaceum & Rambutan (cipelat) & & v \\
\hline 51 & Nephelium lappaceum & Rambutan (rapiah) & & $v$ \\
\hline$\frac{5}{5}$ & $\begin{array}{l}\text { Paraserianthes } \\
\text { falcataria }\end{array}$ & Sengon & $v$ & \\
\hline 93 & Phoenix roebelenii & Palem phoenix & & v \\
\hline 54 & Phyllanthus acidus & Cermai & & v \\
\hline 55 & Polyalthia fragrans & Glodogan bulat & v & \\
\hline 56 & Polyalthia longifolia & Glodogan tiang & v & v \\
\hline 757 & Pometia pinnata & Matoa & v & \\
\hline 58 & Psidium guajava & Jambu batu & & v \\
\hline 59 & Pterocarpus indicus & Angsana & $\mathrm{v}$ & \\
\hline 60 & $\begin{array}{l}\text { Ptychosperma } \\
\text { macarthurii }\end{array}$ & Palem hijau & & v \\
\hline 61 & Punica granatum & Delima & & v \\
\hline 62 & Roystonea regia & Palem raja & v & \\
\hline 63 & Sandoricum koetjape & Kecapi & & v \\
\hline 64 & Swietenia macrophylla & Mahoni & v & \\
\hline 65 & Syzygium polyanthum & Salam & v & \\
\hline 66 & Syzygium aqueum & Jambu air & & v \\
\hline 67 & Syzygium aqueum & Jambu air (kancing) & & v \\
\hline 68 & Syzygium aqueum & Jambu air (putih) & & v \\
\hline 69 & Syzygium cumini & Jamblang & & v \\
\hline 70 & $\begin{array}{l}\text { Syzygium } \\
\text { malasccensis }\end{array}$ & Jambu bol & & v \\
\hline 71 & $\begin{array}{l}\text { Syzygium } \\
\text { samarangense }\end{array}$ & $\begin{array}{l}\text { Jambu air semarang } \\
\text { (cincolo) }\end{array}$ & & v \\
\hline 72 & Tectona grandis & Jati & v & v \\
\hline 73 & Terminalia catappa & Ketapang & $v$ & \\
\hline 74 & Veitchia merilii & Palem putri & v & v \\
\hline 95 & Wodyetia bifurcata & Palem ekor tupai & & $\mathrm{v}$ \\
\hline
\end{tabular}

Berdasarkan data jenis-jenis pohon hasil inventarisasi yang tertera pada tabel, maka dapat dikatakan bahwa terdapat total 75 jenis pohon yang terdapat pada area studi Perkampungan Budaya Betawi Setu Babakan, dengan masingmasing 42 jenis pohon pada sepuluh pekarangan contoh dan 43 jenis pohon pada area lingkar Setu Babakan. 


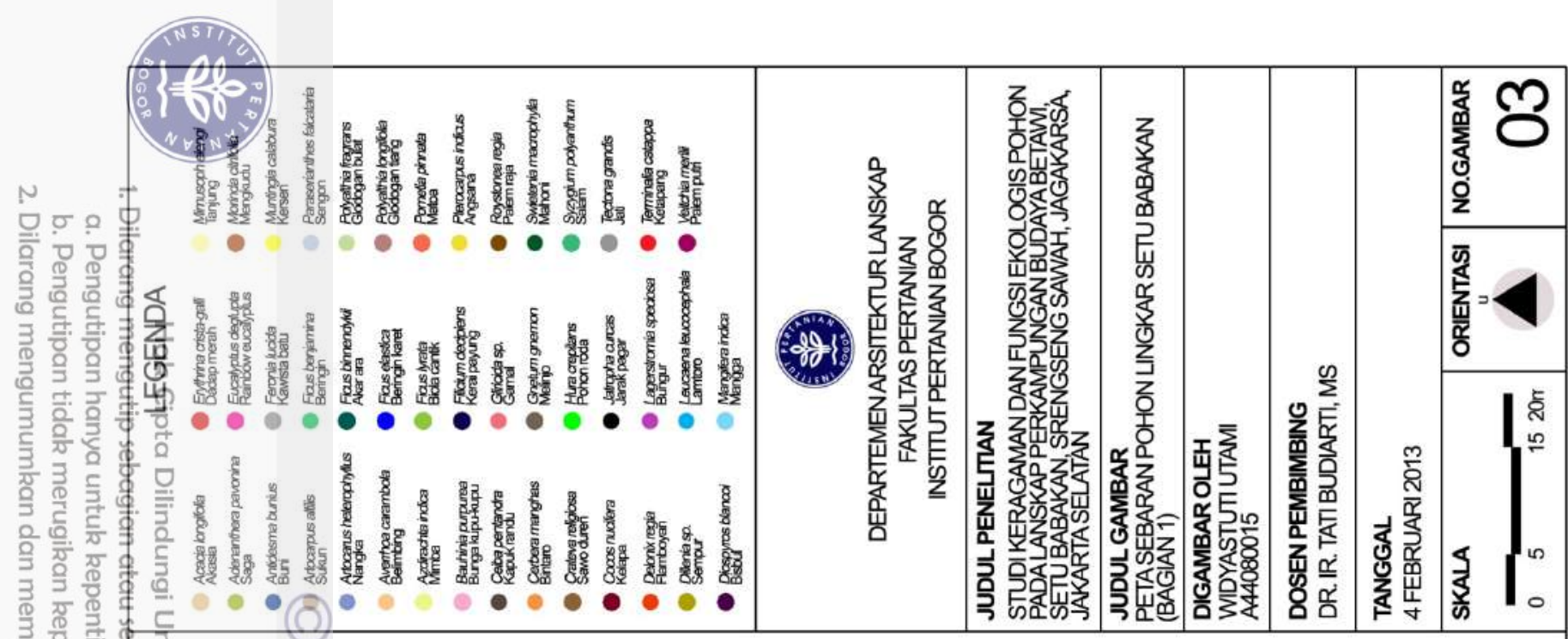

을
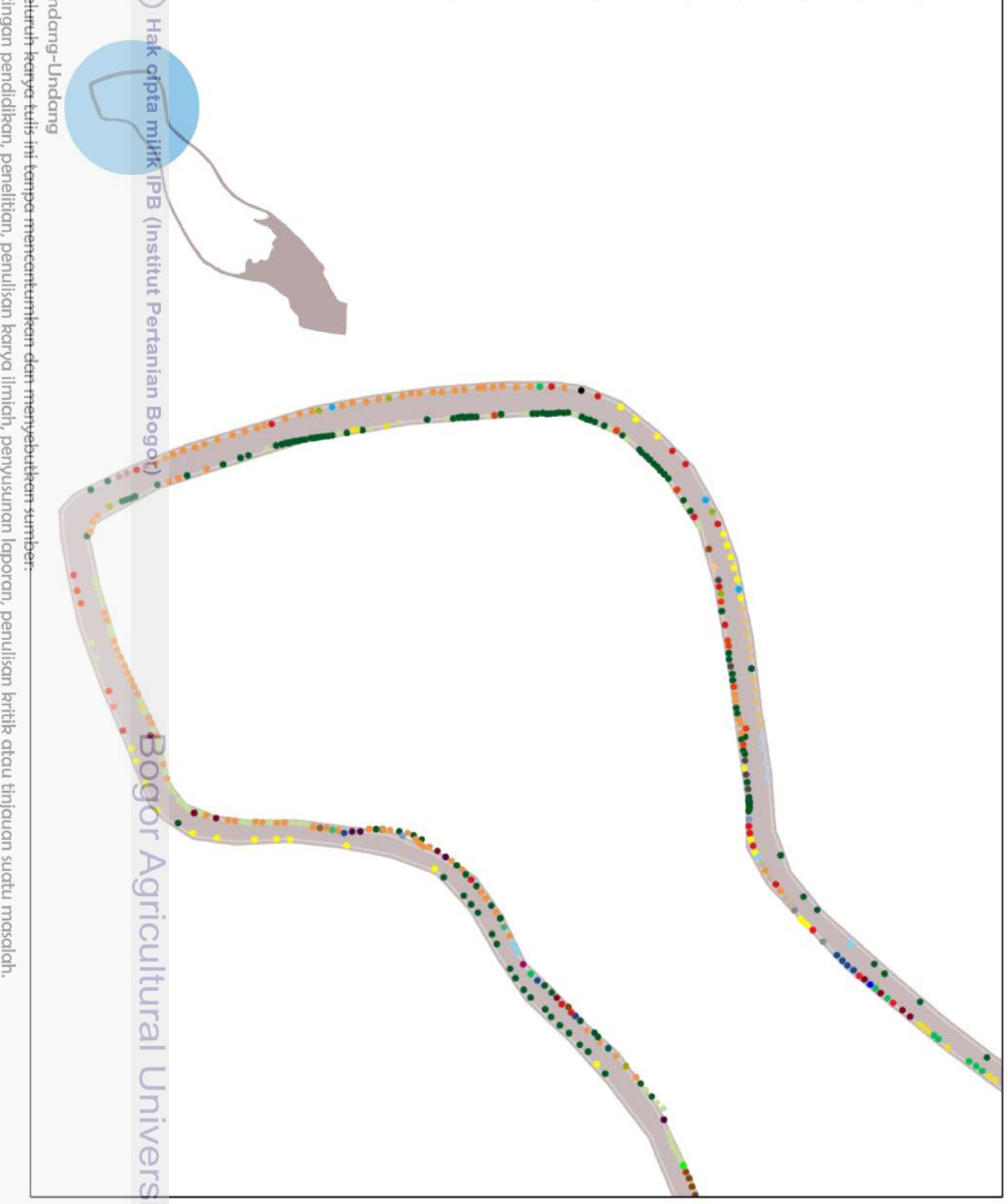

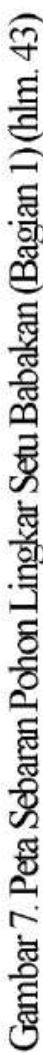




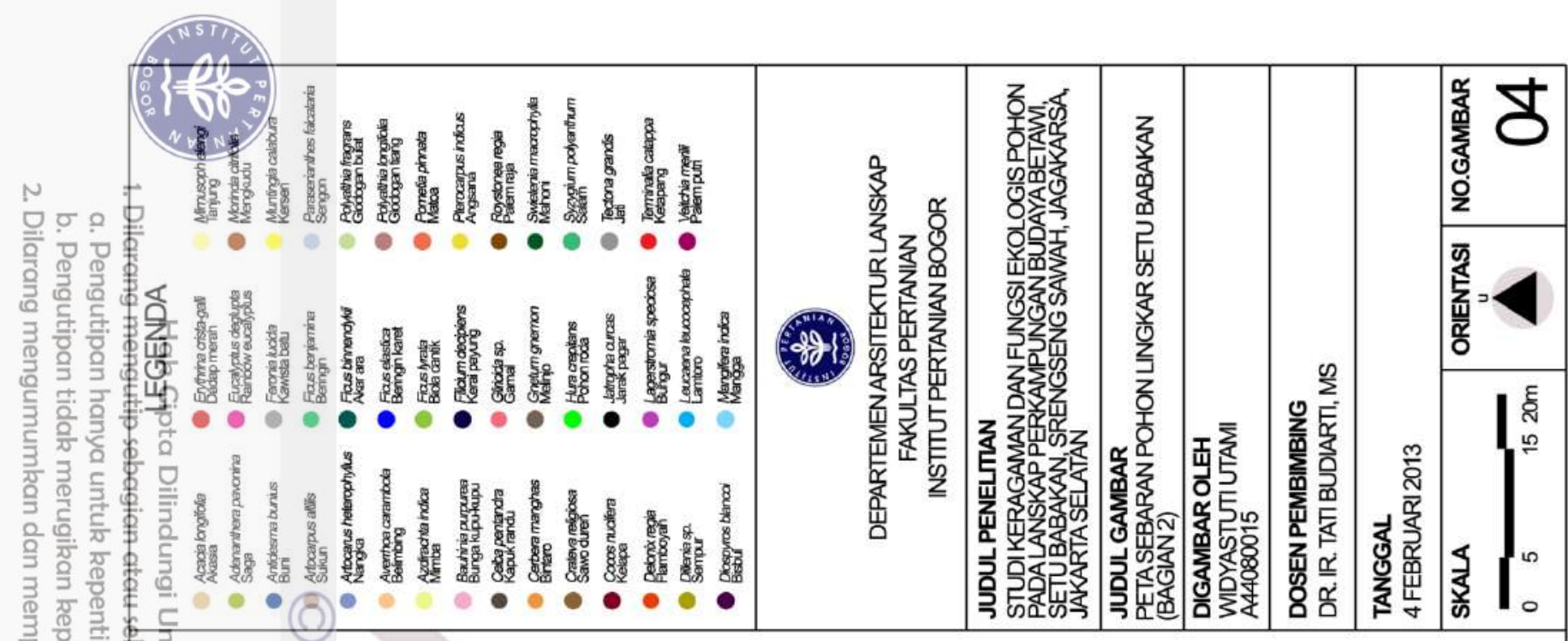

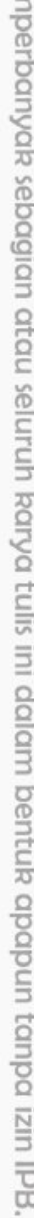

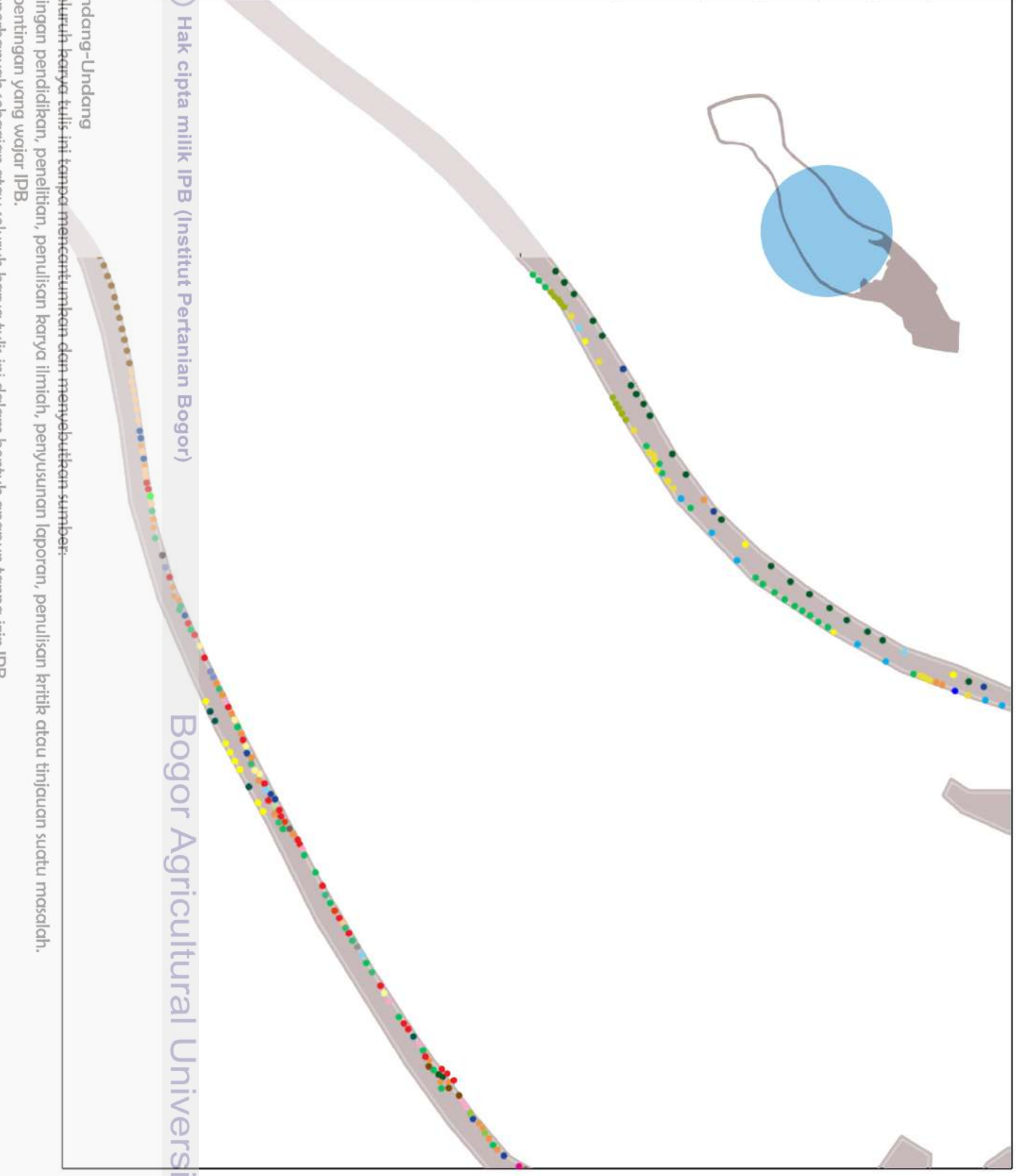




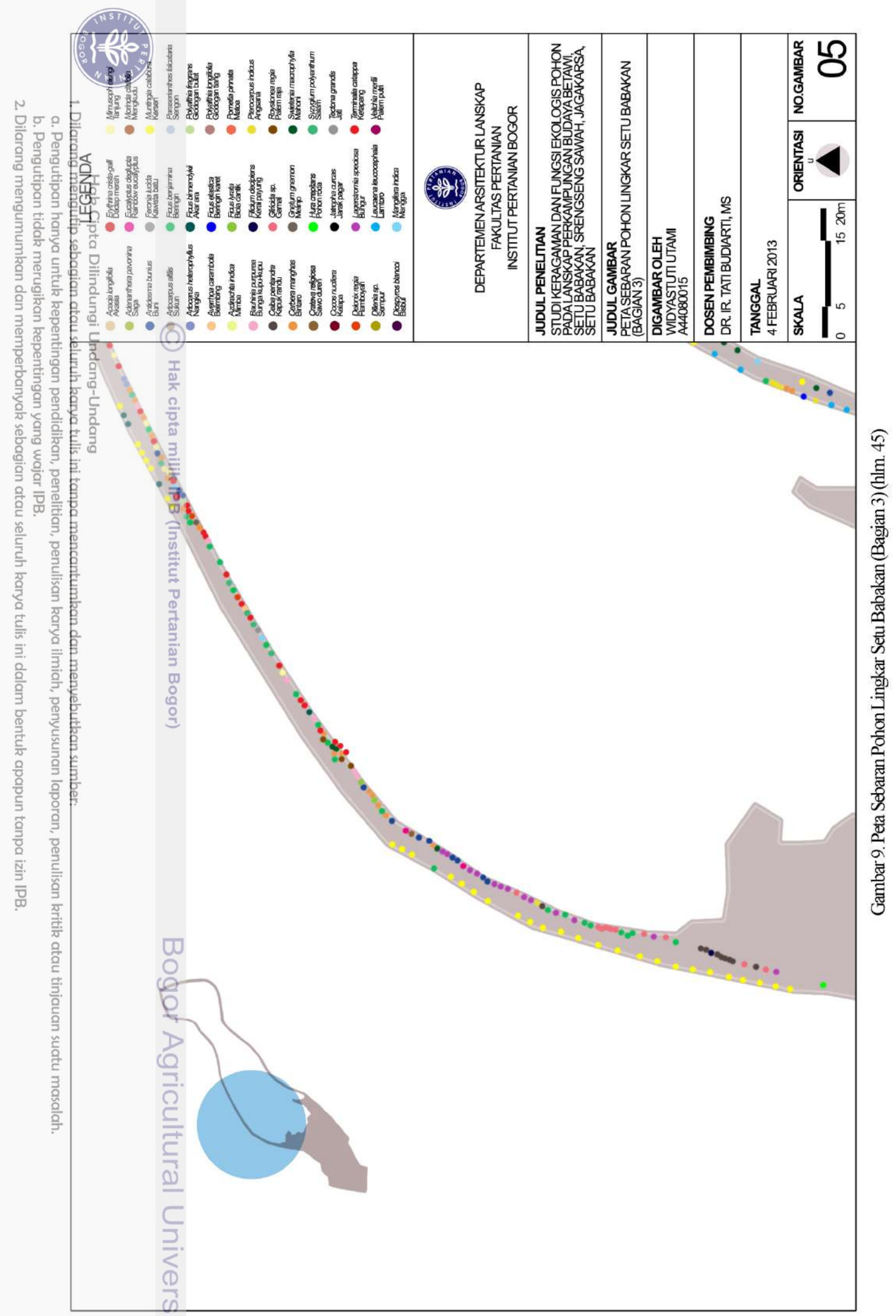




\subsection{Analisis Nilai Keragaman Pohon}

Setu Babakan sebagai sebuah kawasan konservasi budaya Betawi dan rekreasi menyimpan berbagai jenis keragaman pohon. Salah satu kawasan yang termasuk ke dalamnya adalah sebuah danau atau setu yang dikelilingi oleh pepohonan di sepanjang jalur pejalan kaki. Keragaman tersebut sangatlah penting untuk tetap dijaga dan dilestarikan, selain untuk mempertahankan nilai ekosistem, hal ini juga berkaitan dengan nilai budaya kawasan yang direpresentasikan

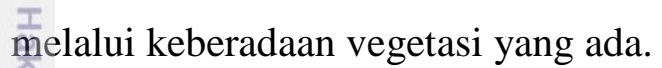

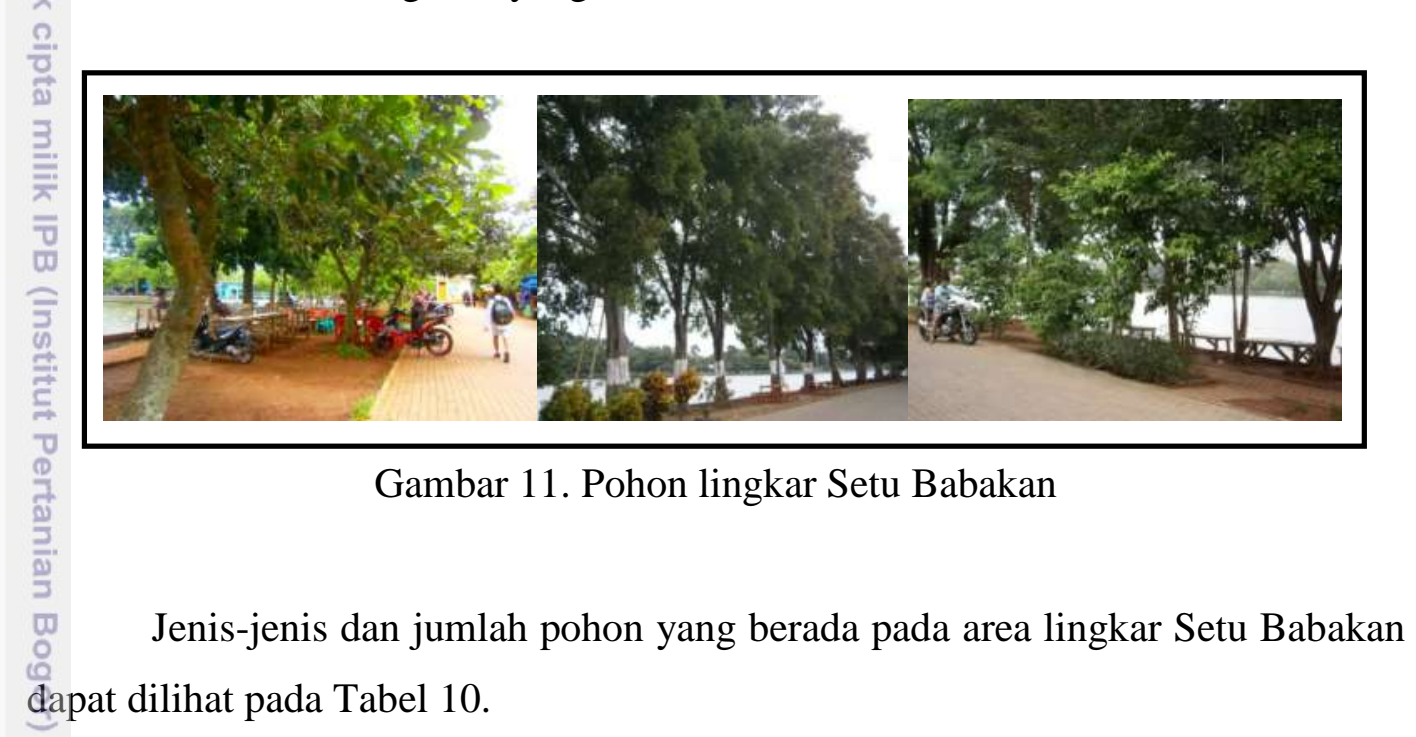

Tabel 10. Daftar Jumlah Pohon pada Lingkar Setu Babakan

\begin{tabular}{cllc}
\hline No & \multicolumn{1}{c}{ Nama Latin } & \multicolumn{1}{c}{ Nama Lokal } & Jumlah Individu \\
\hline 1 & Acacia longifolia & Akasia & 10 \\
2 & Adenanthera pavonina & Saga & 42 \\
3 & Antidesma bunius & Buni & 29 \\
4 & Artocarpus altilis & Sukun & 4 \\
5 & Artocarpus heterophyllus & Nangka & 5 \\
6 & Averrhoa carambola & Belimbing & 12 \\
67 & Azadirachta indica & Mimba & 3 \\
8 & Bauhinia purpurea & Kupu-kupu & 6 \\
9 & Ceiba pentandra & Kapuk randu & 15 \\
010 & Cerbera manghas & Bintaro & 116 \\
71 & Crateva religiosa & Sawo duren & 2 \\
12 & Cocos nucifera & Kelapa & 9 \\
\hline 13 & Delonix regia & Flamboyan & 14 \\
914 & Dillenia sp. & Sempur & 1 \\
915 & Diospyros blancoi & Bisbul & 4 \\
\hline 16 & Erythrina crista-galli & Dadap merah & 12 \\
\hline
\end{tabular}


Tabel 10. Daftar Jumlah Pohon pada Lingkar Setu Babakan (Lanjutan)

\begin{tabular}{|c|c|c|c|}
\hline No & Nama Latin & Nama Lokal & Jumlah Individu \\
\hline 17 & Eucalyptus deglupta & Rainbow eucalyptus & 2 \\
\hline 18 & Feronia lucida & Kawista batu & 2 \\
\hline 19 & Ficus benjamina & Beringin & 53 \\
\hline 20 & Ficus binnendykii & Akar ara & 5 \\
\hline 21 & Ficus elastica & Beringin karet & 3 \\
\hline 22 & Ficus lyrata & Biola cantik & 2 \\
\hline 23 & Filicium decipiens & Kerai payung & 1 \\
\hline 24 & Gliricidia sp. & Gamal & 10 \\
\hline 25 & Gnetum gnemon & Melinjo & 1 \\
\hline 26 & Hura crepitans & Pohon roda & 3 \\
\hline$=27$ & Lagerstromia speciosa & Bungur & 13 \\
\hline 28 & Leucaena leucocephala & Lamtoro & 13 \\
\hline 29 & Mangifera indica & Mangga & 5 \\
\hline 30 & Mimusoph elengi & Tanjung & 6 \\
\hline 31 & Morinda citrifolia & Mengkudu & 2 \\
\hline 32 & Muntingia calabura & Kersen & 64 \\
\hline 33 & Paraserianthes falcataria & Sengon & 4 \\
\hline 34 & Polyalthia fragrans & Glodogan bulat & 51 \\
\hline 35 & Polyalthia longifolia & Glodogan tiang & 3 \\
\hline 36 & Pometia pinnata & Matoa & 1 \\
\hline 37 & Pterocarpus indicus & Angsana & 25 \\
\hline 38 & Roystonea regia & Palem raja & 17 \\
\hline 39 & Swietenia macrophylla & Mahoni & 145 \\
\hline 40 & Syzygium polyanthum & Salam & 12 \\
\hline 41 & Tectona grandis & Jati & 4 \\
\hline 42 & Terminalia catappa & Ketapang & 45 \\
\hline 43 & Veitchia merilii & Palem putri & 1 \\
\hline \multicolumn{3}{|c|}{ Total Pohon } & 777 \\
\hline
\end{tabular}

Melalui perhitungan dari rumus Shannon-Wiener (Odum 1998) yang digunakan untuk mengetahui nilai index keragaman pohon, maka diperoleh nilai Sebagai berikut $: \mathrm{H}=3.322\left(\log 777-\Sigma\left(\frac{N i(\log N i)}{777}\right)\right)=4.23$

Nilai index keragaman pohon yang diperoleh dari perhitungan adalah Sebesar 4.23. Hasil tersebut menunjukkan bahwa tingkat keragaman spesies pohon yang berada di kawasan lingkar setu adalah tinggi, dengan nilai index lebih dari angka 3. Adapun jenis pohon yang paling banyak pada kawasan adalah mahoni (Swietenia macrophylla) dengan presentase 18.66\% (145 pohon) dan bintaro (Cerbera manghas) dengan presentase $14.93 \%$ (116) pohon dari total yang 
diinventarisasi sebanyak 777 pohon. Jenis pohon dengan jumlah sedikit (1-2 pohon), yaitu sawo duren (Crateva religiosa), sempur (Dillenia sp.), rainbow eucalyptus (Eucalyptus deglupta), kawista batu (Feronia lucida), biola cantik (Ficus lyrata), kerai payung (Filicium decipiens), melinjo (Gnetum gnemon), mengkudu (Morinda citrifolia), matoa (Pometia pinnata), dan palem putri (Veitchia merilii).

Meskipun tingkat keragaman spesies pada kawasan lingkar Setu Babakan đapat dikatakan tinggi, namun jenis-jenis pohon non-eksotik seperti mahoni dan bintaro lebih banyak mendominasi. Pada kawasan ini jenis pohon langka berjumlah sedikit, menyebar, dan tidak ditemukan tipe penanaman yang berkelompok. Kondisi tersebut menunjukkan bahwa pemilihan jenis-jenis pohon yang berada di kawasan lingkar setu lebih diutamakan kepada jenis yang memiliki fungsi sebagai peneduh dan ameliorasi iklim serta jenis pohon yang tumbuh baik đi tepi danau (perairan darat) dan mudah tumbuh. Hal ini juga dapat dikarenakan fungsi setu itu sendiri sebagai kawasan rekreasi sehingga dibutuhkan jenis-jenis pohon yang dapat memberikan kenyamanan bagi pengunjung area tersebut.

Selain area lingkar setu, kawasan rekreasi Setu Babakan juga terdiri dari ૈㅡำah-rumah warga dengan pekarangannya yang biasa digunakan untuk melihat secara langsung tanaman-tanaman khas terutama pohon penghasil buah. Contoh pekarangan yang digunakan sebagai bahan penelitian adalah sebanyak 10 buah dengan sistem pengambilan secara acak.

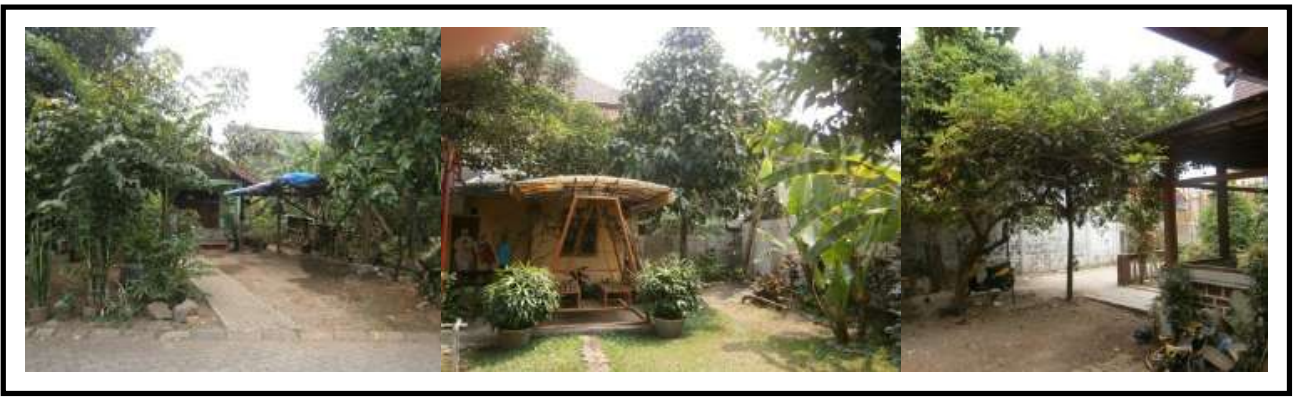

Gambar 12. Pohon pada area pekarangan 
Jenis-jenis pohon dan jumlah pohon pada setiap pekarangan contoh dapat dilihat pada Tabel 11.

Tabel 11. Jenis-Jenis Pohon pada Pekarangan Contoh

\begin{tabular}{|c|c|c|c|c|c|c|c|c|c|c|c|c|}
\hline \multirow{2}{*}{ No } & \multirow{2}{*}{ Nama Latin } & \multirow{2}{*}{ Nama Lokal } & \multicolumn{10}{|c|}{ Pekarangan } \\
\hline & & & 1 & 2 & 3 & 4 & 5 & 6 & 7 & 8 & 9 & 10 \\
\hline (1) & $\begin{array}{l}\text { Annona } \\
\text { squamosa }\end{array}$ & Srikaya & & & & & & & & & 1 & \\
\hline$\overline{2}$ & Areca catechu & Pinang & & & & & 3 & & & & 3 & \\
\hline$\frac{3}{3}$ & $\begin{array}{l}\text { Artocarpus } \\
\text { heterophyllus }\end{array}$ & Nangka & & & 1 & 1 & & & & & 1 & 1 \\
\hline$\frac{3}{3}$ & $\begin{array}{l}\text { Averrhoa } \\
\text { carambola }\end{array}$ & Belimbing & & & 2 & & & 1 & & 5 & & \\
\hline$\stackrel{\sqrt{0}}{=}$ & $\begin{array}{l}\text { Cananga } \\
\text { odorata }\end{array}$ & Kenanga & 1 & & & & & 1 & & & & \\
\hline 6 & Citrus maxima & Jeruk bali & & & & 4 & & & & & & \\
\hline $\overrightarrow{7}$ & $\begin{array}{l}\text { Crateva } \\
\text { religiosa }\end{array}$ & Sawo duren & & & & & 1 & & & & & \\
\hline 8 & Coryota mitis & Palem ekor ikan & & 2 & & & & & & & & \\
\hline 9 & $\begin{array}{l}\text { Dimocarpus } \\
\text { longan }\end{array}$ & Lengkeng & & & & & & 1 & & & & \\
\hline \$0 & $\begin{array}{l}\text { Durio } \\
\text { zibethinus }\end{array}$ & Durian montong & & & & & & & & & & 2 \\
\hline 11 & Feronia lucida & Kawista batu & & & & & 1 & & & & & \\
\hline 12 & $\begin{array}{l}\text { Ficus } \\
\text { benjamina }\end{array}$ & Beringin & & & & & & & & 1 & & \\
\hline 13 & $\begin{array}{l}\text { Flacourtia } \\
\text { rukam }\end{array}$ & Rukem & & 1 & & & & & & & & \\
\hline 14 & Gnetum gnemon & Melinjo & & & 2 & 1 & 1 & & & & 2 & 1 \\
\hline 15 & $\begin{array}{l}\text { Lansium } \\
\text { domesticum }\end{array}$ & Duku condet & 1 & & & & & & & & & \\
\hline 16 & $\begin{array}{l}\text { Mangifera } \\
\text { indica }\end{array}$ & Mangga (apel) & & & & & 1 & & & & & \\
\hline 97 & $\begin{array}{l}\text { Mangifera } \\
\text { indica }\end{array}$ & $\begin{array}{l}\text { Mangga (arum } \\
\text { manis) }\end{array}$ & & & 3 & & & 1 & 1 & 3 & & 2 \\
\hline 18 & $\begin{array}{l}\text { Mangifera } \\
\text { indica }\end{array}$ & $\begin{array}{l}\text { Mangga } \\
\text { (okyong) }\end{array}$ & & & & & & 1 & & & & \\
\hline 19 & $\begin{array}{l}\text { Manilkara } \\
\text { zapota }\end{array}$ & $\begin{array}{l}\text { Sawo manila } \\
\text { (betawi) }\end{array}$ & & & & & & & & & & 1 \\
\hline 20 & $\begin{array}{l}\text { Manilkara } \\
\text { zapota }\end{array}$ & $\begin{array}{l}\text { Sawo manila } \\
\text { (kulon) }\end{array}$ & & 1 & 1 & & & & & & & \\
\hline 21 & $\begin{array}{l}\text { Morinda } \\
\text { citrifolia }\end{array}$ & Mengkudu & & 1 & & & & & & & 1 & \\
\hline 22 & $\begin{array}{l}\text { Nephelium } \\
\text { lappaceum }\end{array}$ & Rambutan (aceh) & & & & & & 1 & & & & \\
\hline
\end{tabular}


Tabel 11. Jenis-Jenis Pohon pada Pekarangan Contoh (Lanjutan)

\begin{tabular}{|c|c|c|c|c|c|c|c|c|c|c|c|c|}
\hline \multirow{2}{*}{ No } & \multirow{2}{*}{ Nama Latin } & \multirow{2}{*}{ Nama Lokal } & \multicolumn{10}{|c|}{ Pekarangan } \\
\hline & & & 1 & 2 & 3 & 4 & 5 & 6 & 7 & 8 & 9 & 10 \\
\hline 23 & $\begin{array}{l}\text { Nephelium } \\
\text { lappaceum }\end{array}$ & $\begin{array}{l}\text { Rambutan } \\
\text { (binjai) }\end{array}$ & & 1 & 1 & & & 1 & 2 & 1 & 4 & \\
\hline 24 & $\begin{array}{l}\text { Nephelium } \\
\text { lappaceum }\end{array}$ & $\begin{array}{l}\text { Rambutan } \\
\text { (cimacan) }\end{array}$ & & & & & & & & & & 1 \\
\hline 25 & $\begin{array}{l}\text { Nephelium } \\
\text { lappaceum }\end{array}$ & $\begin{array}{l}\text { Rambutan } \\
\text { (cipelat) }\end{array}$ & & & & & & & & & & 2 \\
\hline$\overline{2} 6$ & $\begin{array}{l}\text { Nephelium } \\
\text { lappaceum }\end{array}$ & $\begin{array}{l}\text { Rambutan } \\
\text { (rapiah) }\end{array}$ & & & & & & & & & & 2 \\
\hline$\frac{n}{27}$ & $\begin{array}{l}\text { Phoenix } \\
\text { roebelenii }\end{array}$ & Palem phoenix & 1 & & & & & & & & & \\
\hline$\sum_{2}^{3} 8$ & $\begin{array}{l}\text { Phyllanthus } \\
\text { acidus }\end{array}$ & Cermai & & 2 & & & & & & & & \\
\hline $\begin{array}{l}\bar{v} \\
29\end{array}$ & $\begin{array}{l}\text { Polyalthia } \\
\text { longifolia }\end{array}$ & Glodogan tiang & & & & & & & 1 & & & \\
\hline 30 & $\begin{array}{l}\text { Psidium } \\
\text { guajava }\end{array}$ & Jambu batu & & & 1 & & 1 & 1 & & & 1 & \\
\hline 31 & $\begin{array}{l}\text { Ptychosperma } \\
\text { macarthurii }\end{array}$ & Palem hijau & 1 & & & & 1 & & & & 1 & \\
\hline 32 & $\begin{array}{l}\text { Punica } \\
\text { granatum }\end{array}$ & Delima & 1 & & & & & & & & & \\
\hline${ }^{\pi} 3$ & $\begin{array}{l}\text { Sandoricum } \\
\text { koetjape }\end{array}$ & Kecapi & & & & & & & & & & 1 \\
\hline 34 & $\begin{array}{l}\text { Syzygium } \\
\text { aqueum }\end{array}$ & Jambu air & & & & 1 & & & 1 & & & \\
\hline 35 & $\begin{array}{l}\text { Syzygium } \\
\text { aqueum }\end{array}$ & $\begin{array}{l}\text { Jambu air } \\
\text { (kancing) }\end{array}$ & & 2 & 1 & & & & & & & \\
\hline 36 & $\begin{array}{l}\text { Syzygium } \\
\text { aqueum }\end{array}$ & Jambu air (putih) & & 1 & & & & & & & & \\
\hline 37 & $\begin{array}{l}\text { Syzygium } \\
\text { cumini }\end{array}$ & Jamblang & & 1 & & & & & & & & \\
\hline 38 & $\begin{array}{l}\text { Syzygium } \\
\text { malasccensis }\end{array}$ & Jambu bol & & & 1 & 1 & & 1 & 1 & & & \\
\hline 39 & $\begin{array}{l}\text { Syzygium } \\
\text { samarangense }\end{array}$ & $\begin{array}{l}\text { Jambu air } \\
\text { semarang } \\
\text { (cincolo) }\end{array}$ & & & & & & & & & & 1 \\
\hline 40 & Tectona grandis & Jati & & & & & & 1 & & & & \\
\hline 41 & Veitchia merilii & Palem putri & & & & & & 3 & & & & 2 \\
\hline 42 & $\begin{array}{l}\text { Wodyetia } \\
\text { bifurcata }\end{array}$ & Palem ekor tupai & & & & & 6 & & & & & \\
\hline Jum & lah spesies & & 5 & 9 & 9 & 5 & 8 & 11 & 5 & 4 & 8 & 11 \\
\hline Jum & lah individu & & 5 & 12 & 13 & 8 & 15 & 13 & 6 & 10 & 14 & 16 \\
\hline
\end{tabular}


Melalui rumus perhitungan dengan metode Shannon-Wiener (Odum 1998), maka diperolehlah nilai index keragaman untuk setiap masing-masing contoh adalah sebagai berikut:

Pekarangan $1\left(63 \mathrm{~m}^{2}\right)$

$\mathrm{H}=3.322\left(\log 5-\Sigma\left(\frac{1(\log 1) 5}{5}\right)\right)=1<2.32<3$,

pekarangan 1 memiliki tingkat keragaman spesies pohon yang sedang.

Tํ.

\section{Pekarangan $2\left(70 \mathrm{~m}^{2}\right)$}

$\overrightarrow{\mathrm{H}}=3.322\left(\log 12-\Sigma\left(\frac{1(\log 1) 6+2(\log 2) 3}{12}\right)\right)=3.09>3$

pekarangan 2 memiliki tingkat keragaman spesies pohon yang tinggi.

Pekarangan $3\left(78 \mathrm{~m}^{2}\right)$

$\widehat{\overline{\bar{H}}}=3.322\left(\log 13-\Sigma\left(\frac{1(\log 1) 6+2(\log 2) 2+3(\log 3)}{13}\right)\right)=3.03>3$

pekarangan 3 memiliki tingkat keragaman spesies pohon yang tinggi.

Pekarangan $4\left(125 \mathrm{~m}^{2}\right)$

$\mathrm{H}=3.322\left(\log 8-\Sigma\left(\frac{1(\log 1) 4+4(\log 4)}{8}\right)\right)=1<2.00<3$

pekarangan 4 memiliki tingkat keragaman spesies pohon yang sedang.

Pekarangan $5\left(163 \mathrm{~m}^{2}\right)$

$\mathrm{H}=3.322\left(\log 15-\Sigma\left(\frac{1(\log 1) 6+3(\log 3)+6(\log 6)}{15}\right)\right)=1<2.56<3$

pekarangan 5 memiliki tingkat keragaman spesies pohon yang sedang.

Pekarangan $6\left(250 \mathrm{~m}^{2}\right)$

$\mathrm{H}=3.322\left(\log 13-\Sigma\left(\frac{1(\log 1) 10+3(\log 3)}{13}\right)\right)=3.33>3$

pekarangan 6 memiliki tingkat keragaman spesies pohon yang tinggi.

Pekarangan $7\left(300 \mathrm{~m}^{2}\right)$

$\mathrm{H}=3.322\left(\log 6-\Sigma\left(\frac{1(\log 1) 4+2(\log 2)}{6}\right)\right)=1<2.25<3$

pekarangan 7 memiliki tingkat keragaman spesies pohon yang sedang.

Pekarangan $8\left(320 \mathrm{~m}^{2}\right)$

$\underline{\mathrm{H}}=3.322\left(\log 10-\Sigma\left(\frac{1(\log 1) 2+3(\log 3)+5(\log 5)}{10}\right)\right)=1<1.69<3$

pekarangan 8 memiliki tingkat keragaman spesies pohon yang sedang.

Pekarangan $9\left(400 \mathrm{~m}^{2}\right)$ 
$\mathrm{H}=3.322\left(\log 14-\Sigma\left(\frac{1(\log 1) 5+2(\log 2)+3(\log 3)+4(\log 4)}{14}\right)\right)=1<2.75<3$

pekarangan 9 memiliki tingkat keragaman spesies pohon yang sedang. Pekarangan $10\left(600 \mathrm{~m}^{2}\right)$

$\mathrm{H}=3.322\left(\log 16-\Sigma\left(\frac{1(\log 1) 6+2(\log 2) 5}{16}\right)\right)=3.38<3$

pekarangan 10 memiliki tingkat keragaman spesies pohon yang tinggi.

Berdasarkan hasil perhitungan di atas, terdapat 4 pekarangan $(2,3,6,10)$ yāng memiliki tingkat keragaman tinggi, 6 (1,4,5,7,8,9) pekarangan dengan tịngkat keragaman sedang, dan tidak terdapat pekarangan yang memiliki tingkat keragaman rendah. Nilai index keragaman spesies tertinggi terdapat pada pekarangan $10\left(600 \mathrm{~m}^{2}\right)$ dengan nilai 3.38 serta memiliki jumlah pohon sebanyak $\overline{\overline{16}}$ (11 spesies). Adapun nilai keragaman spesies terendah terdapat pada 夜karangan $8\left(320 \mathrm{~m}^{2}\right)$ dengan nilai 1.69 serta memiliki jumlah pohon sebanyak 10 (4 spesies).

Tidak seperti jenis-jenis pohon yang terdapat pada lingkar setu, jenis pohon yang berada pada pekarangan cenderung lebih beragam serta terdiri dari lejbih banyak pohon yang menghasilkan buah dengan berbagai varietas. Oleh karena itu, dapat dikatakan bahwa pilihan penanaman pohon pada pekarangan lebih difungsikan sebagai sarana pelestarian spesies dan fungsi produksi (konsumsi) baik bagi pemilik pekarangan rumah itu sendiri maupun masyarakat setempat, termasuk sarana rekreasi agro dan edukasi bagi pengunjung.

\subsection{Analisis Fungsi Ekologis Pohon pada Area Lingkar Setu Babakan}

Penilaian dilakukan terhadap fungsi vegetasi pohon pada Setu Babakan berdasarkan kriteria masing-masing, yaitu kategori sangat baik (SB), kategori baik (BA), kategori kurang baik (KB), dan kategori buruk (BU). Tahapan ini dipaparkan melalui tabel dan penjelasan secara deskriptif.

\subsubsection{Modifikasi Suhu sebagai Penaung}

Jumlah pohon besar yang berada di lingkungan danau Setu Babakan cukup banyak, sehingga pengunjung yang datang ke kawasan ini cukup lama singgah untuk melepas kepenatan dan menikmati kesejukan yang dihasilkan dari ragam hijauan yang rindang. Melalui penilaian yang telah dilakukan, maka diperoleh 
kriteria kesesuaian fisik vegetasi terhadap kriteria fungsi ekologis modifikasi suhu (Tabel 12).

Tabel 12. Kriteria Penilaian Aspek Fungsi Modifikasi Suhu sebagai Penaung

\begin{tabular}{|c|c|c|c|c|c|c|c|}
\hline \multirow{3}{*}{ No } & \multirow{3}{*}{ Nama Latin } & \multirow{3}{*}{ Nama Lokal } & \multirow{2}{*}{\multicolumn{3}{|c|}{$\begin{array}{l}\text { Kriteria Fungsi } \\
\text { Modifikasi Suhu }\end{array}$}} & \multirow{3}{*}{ Skor (\%) } & \multirow{3}{*}{ Kategori } \\
\hline & & & & & & & \\
\hline & & & K1 & K2 & K3 & & \\
\hline$(1)$ & Acacia longifolia & Akasia & 4 & 3 & 4 & 91.67 & SB \\
\hline 72 & Adenanthera pavonina & Saga & 4 & 4 & 2 & 83.33 & SB \\
\hline$\pi^{3}$ & Antidesma bunius & Buni & 4 & 2 & 4 & 83.33 & SB \\
\hline$\overline{-4}$ & Artocarpus altilis & Sukun & 4 & 3 & 2 & 75.00 & BA \\
\hline 5 & Artocarpus heterophyllus & Nangka & 1 & 2 & 3 & 50.00 & KB \\
\hline 6 & Averrhoa carambola & Belimbing & 1 & 1 & 3 & 41.67 & KB \\
\hline $\overrightarrow{7}$ & Azadirachta indica & Mimba & 4 & 3 & 3 & 83.33 & SB \\
\hline ర8 & Bauhinia purpurea & Kupu-kupu & 4 & 2 & 3 & 75.00 & BA \\
\hline 9 & Ceiba pentandra & Kapuk randu & 4 & 4 & 3 & 91.67 & SB \\
\hline \pm 0 & Cerbera manghas & Bintaro & 4 & 3 & 2 & 75.00 & BA \\
\hline 11 & Crateva religiosa & Sawo duren & 4 & 3 & 4 & 91.67 & SB \\
\hline 12 & Cocos nucifera & Kelapa & 4 & 1 & 2 & 58.33 & KB \\
\hline 13 & Delonix regia & Flamboyan & 4 & 4 & 2 & 83.33 & SB \\
\hline 14 & Dillenia sp. & Sempur & 4 & 2 & 3 & 75.00 & BA \\
\hline 15 & Diospyros blancoi & Bisbul & 4 & 3 & 4 & 91.67 & SB \\
\hline 16 6 & Erythrina crista-galli & Dadap merah & 1 & 2 & 2 & 41.67 & KB \\
\hline 17 & Eucalyptus deglupta & Rainbow eucalyptus & 4 & 2 & 1 & 58.33 & KB \\
\hline 18 & Feronia lucida & Kawista batu & 1 & 1 & 1 & 25.00 & BU \\
\hline 19 & Ficus benjamina & Beringin & 4 & 4 & 4 & 100.00 & SB \\
\hline 20 & Ficus binnendykii & Akar ara & 4 & 4 & 4 & 100.00 & SB \\
\hline 21 & Ficus elastica & Beringin karet & 4 & 4 & 4 & 100.00 & SB \\
\hline 22 & Ficus lyrata & Biola cantik & 4 & 4 & 4 & 100.00 & SB \\
\hline 23 & Filicium decipiens & Kerai payung & 4 & 3 & 4 & 91.67 & SB \\
\hline 24 & Gliricidia sp. & Gamal & 4 & 3 & 2 & 75.00 & BA \\
\hline 25 & Gnetum gnemon & Melinjo & 1 & 1 & 4 & 50.00 & KB \\
\hline 26 & Hura crepitans & Pohon roda & 4 & 4 & 4 & 100.00 & SB \\
\hline 27 & Lagerstromia speciosa & Bungur & 4 & 3 & 4 & 91.67 & SB \\
\hline 28 & Leucaena leucocephala & Lamtoro & 4 & 4 & 1 & 75.00 & BA \\
\hline 29 & Mangifera indica & Mangga & 4 & 3 & 3 & 83.33 & SB \\
\hline 30 & Mimusoph elengi & Tanjung & 1 & 3 & 4 & 66.67 & BA \\
\hline 31 & Morinda citrifolia & Mengkudu & 1 & 1 & 3 & 41.67 & KB \\
\hline 32 & Muntingia calabura & Kersen & 4 & 3 & 3 & 83.33 & SB \\
\hline 33 & Paraserianthes falcataria & Sengon & 4 & 4 & 2 & 83.33 & SB \\
\hline 34 & Polyalthia fragrans & Glodogan bulat & 1 & 2 & 3 & 50.00 & KB \\
\hline 35 & Polyalthia longifolia & Glodogan tiang & 1 & 1 & 4 & 50.00 & KB \\
\hline 36 & Pometia pinnata & Matoa & 4 & 3 & 4 & 91.67 & SB \\
\hline
\end{tabular}


Tabel 12. Kriteria Penilaian Aspek Fungsi Modifikasi Suhu sebagai Penaung (Lanjutan)

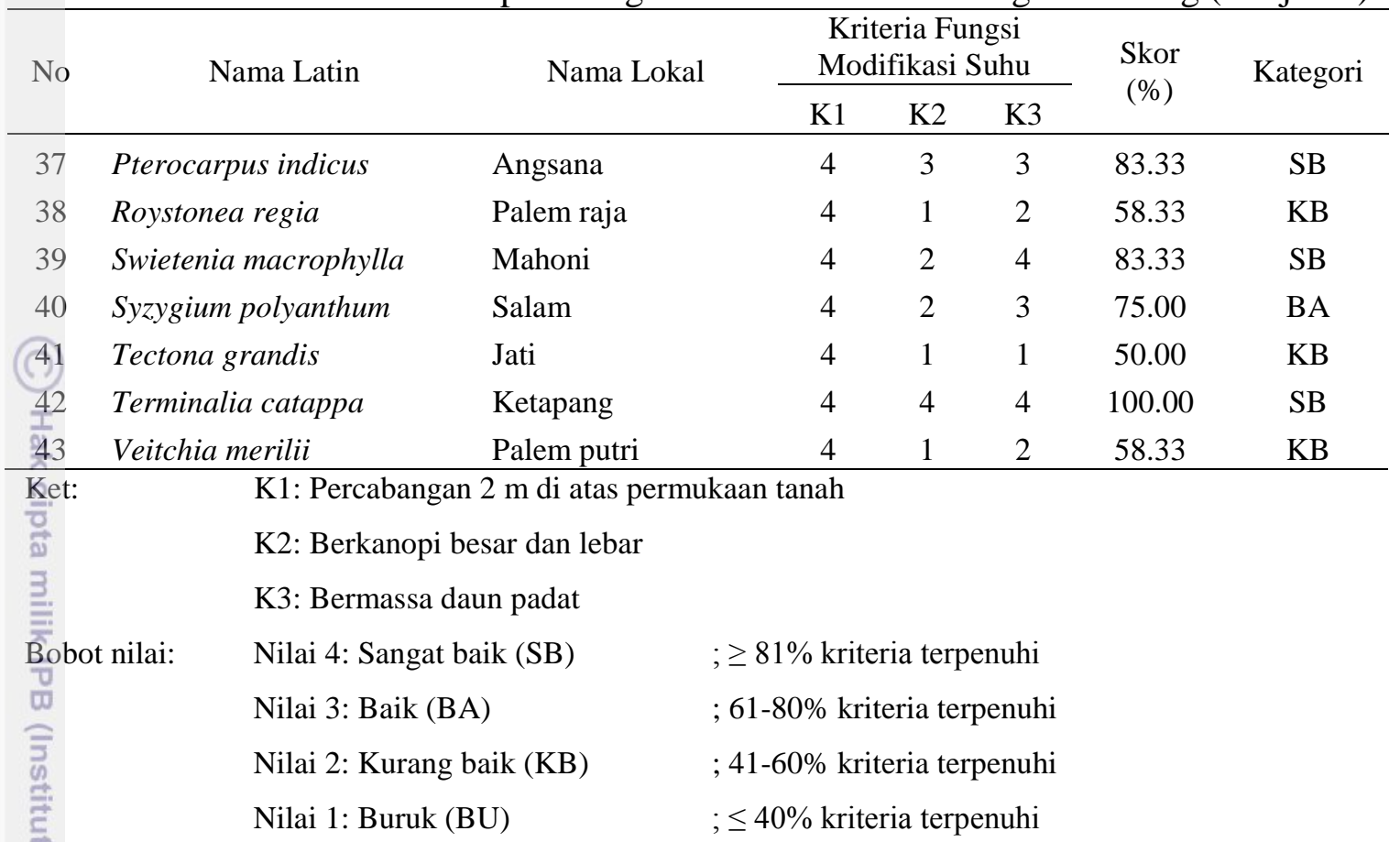

Berdasarkan penilaian karakter fisik yang sesuai dengan karakter fungsi peneduh, maka yang termasuk ke dalam kategori sangat baik, yaitu Acacia Pongifolia (akasia), Adenanthera pavonina (saga), Antidesam bunius (buni), Ceiba pentandra (kapuk randu), Azadirachta indica (mimba), Crateva religiosa (sawo duren), Delonix regia (flamboyan), Diospyros blancoi (bisbul), Ficus benjamina (beringin), Ficus binnendykii (akar ara), Ficus elastic (beringin karet), Ficus lyrata (biola cantik), Filicium decipiens (kerai payung), Hura crepitans (pohon roda), Lagerstromia speciosa (bungur), Mangivera indica (mangga), Muntingia calabura (kersen), Paraserianthes falcataria (sengon), Pometia pinnata (Matoa), Pterocarpus indicus (angsana), Swietenia macrophylla (mahoni), dan Terminalia Catappa (ketapang). Kategori ini mendominasi sebesar 62.81\% dari total individu pohon dan $51.16 \%$ dari total jenis.

Adapun beberapa jenis pohon yang termasuk ke dalam kategori baik, yaitu Artocarpus altilis (sukun), Bauhinia purpurea (bunga kupu-kupu), Cerbera manghas (bintaro), Dillenia sp. (sempur), Gliricidia sp. (gamal), Leucaena teucocephala (lamtoro), Mimusoph elengi (tanjung), dan Syzigium polyanthum (salam). Kategori ini memiliki presentase sebesar $21.62 \%$ dari total individu pohon dan $18.6 \%$ dilihat dari total jenis. 
Kemudian, jenis pohon yang masuk ke dalam kategori kurang baik, yaitu Artocarpus indicus (nangka), Averrhoa indica (belimbing), Cocos nucifera (kelapa), Erythrina crista-galli (dadap merah), Eucalyptus deglupta (rainbow eucalyptus), Gnetum gnemon (melinjo), Morinda citrifolia (mengkudu), Polyalthia fragrans (glodogan bulat), Polyalthia longifolia (glodogan tiang), Roystonea regia (palem raja), Tectona grandis (jati), dan Veitchia merilii (palem putri). Presentase yang diperoleh sebesar 15.32\% dari total individu pohon dan 27.91\% dari total jenis. Maka sisa dari keseluruhan jenis pohon yang ada tergolong ke dalam jenis pohon berkategori buruk, yaitu Feronia lucida (kawista batu) dengan presentase $0.26 \%$ dari total individu pohon dan $2.33 \%$ dari total jenis.

Berdasarkan hasil yang telah diperoleh, terlihat bahwa kawasan lingkar S̄etu Babakan sejuk karena didominasi jenis-jenis pohon berkategori sangat baik đan baik yang tersebar secara merata. Kemudian disusul oleh jenis-jenis pohon berkriteria kurang baik yang didominasi oleh jenis pohon seperti kelapa, palem, đan beberapa di antaranya yang memiliki bentuk kanopi selain bulat atau dome. Adapun jenis yang mampu mencapai nilai sempurna, seperti beringin (Ficus benjamina ), beringin karet (Ficus elastica), biola cantik (Ficus lyrata), pohon roda (Hura crepitans), dan ketapang (Terminalia catappa), tergolong ke dalam pohon-pohon berkanopi lebar dengan tajuk yang rindang. Jenis ini memang biasa digunakan sebagai pohon untuk fungsi peneduh di berbagai lokasi tertentu, seperti halnya pada area rekreasi danau. Manfaat pohon berkanopi lebar sebagai pemodifikasi suhu, yaitu dapat menurunkan suhu lingkungan yang berada di bawah dan sekitar tajuk dengan kemampuannya mereduksi sinar matahari yang masuk, sehingga mampu memberikan efek teduh dan sejuk. 


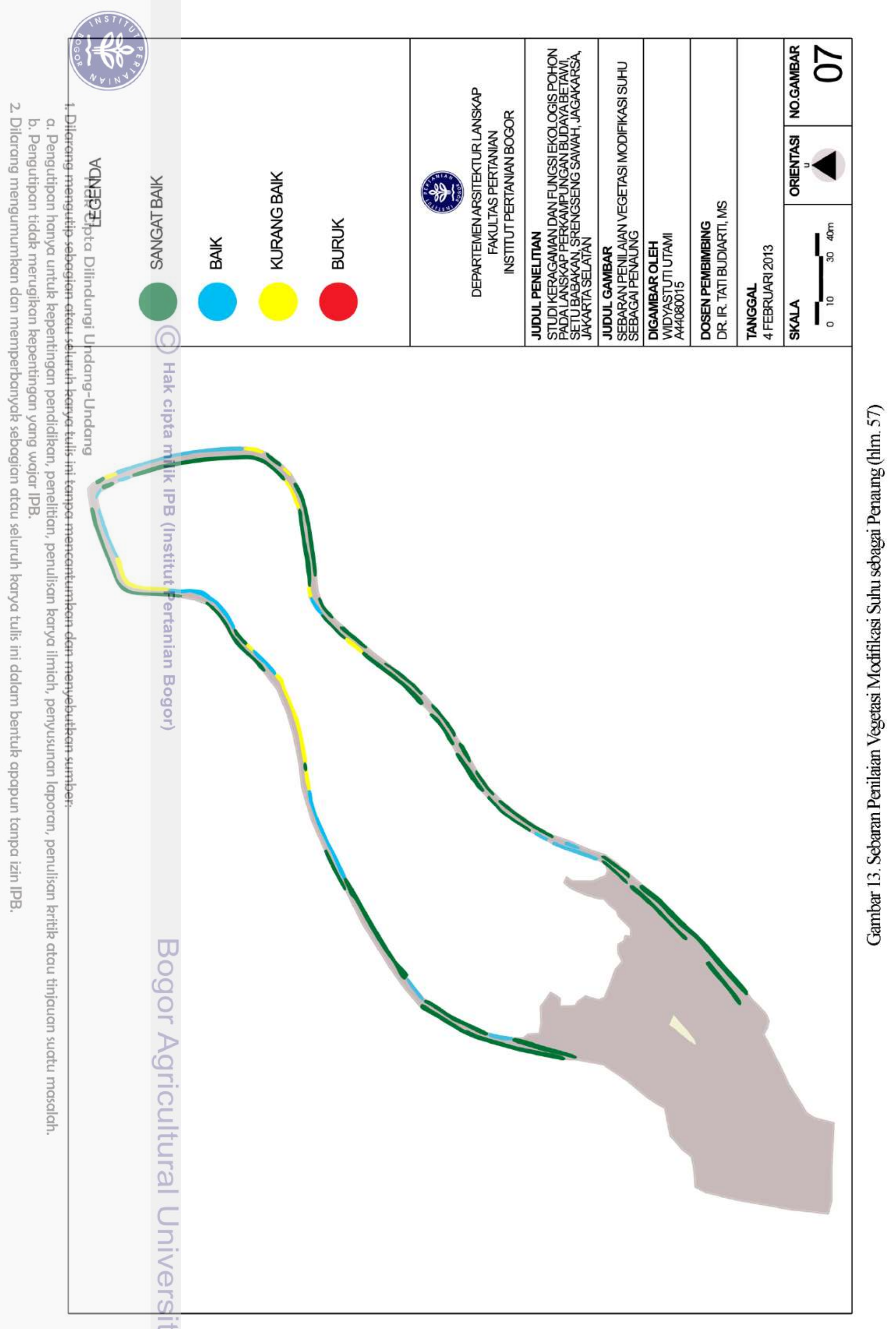


Sebagai sebuah area rekreasi hutan kota atau kawasan yang didominasi ruang terbuka hijau dengan suasana yang teduh, sejuk, rindang, dan asri, Setu Babakan menjadi salah satu tempat rekreasi pilihan yang bertujuan untuk memperoleh kenyamanan. Ruang-ruang hijau di kota Jakarta tergolong menipis, sehingga masyarakat sangat membutuhkan tempat untuk mereka dapat melepas penat dan suasana baru yang nyaman di samping kehidupan kota yang padat. Hal tersebut yang kemudian menjadi bahan pertimbangan dilakukannya analisis untuk menunjukkan seberapa besar kawasan tersebut mampu memberikan manfaat bagi pengunjung maupun masyarakat sekitar.

Berdasarkan peta dari sebaran penilaian fungsi ekologis untuk modifikasi sühu, terlihat bahwa sebaran pohon dengan kategori sangat baik dan baik hampir secara merata mendominasi kawasan. Pada bagian timur, penutupan vegetasi đidominasi oleh saga (Adenanthera pavonina), beringin (Ficus benjamina), dan ketapang (Terminalia catappa). Selain itu, beberapa di antaranya terdapat pula akasia (Acacia longifolia) dan mahoni (Swietenia macrophylla). Penutupan vegetasi cenderung rapat, terutama pada bagian sisi danau. Kondisi yang dihasilkan dari jenis penutupan vegetasi ini digunakan rata-rata pengunjung untuk memancing dan bersantai. Pada area bagian barat hingga selatan, penutupan vegetasi juga dapat dikatakan baik. Jenis-jenis pohon yang mendominasi, yaitu buni (Antidesma bunius), beringin (Ficus benjamina), bungur (Lagerstromia speciosa), dan ketapang (Terminalia catappa). Pengunjung pada area ini lebih banyak memanfaatkan penutupan vegetasi untuk bersantai dan menikmati pemandangan. Tidak banyak aktivitas memancing, namun hal tersebut lebih banyak dilakukan oleh penduduk yang tinggal bersebelahan dengan danau. Selain itu, bintaro (Cerbera manghas) dan mahoni (Swietenia macrophylla) (mendominasi pada area lingkar danau bagian utara. Dominasi pohon dengan kategori kurang baik terdapat pada bagian tepi tengah danau. Jenis pohon yang mendominasi adalah palem raja (Roystonea regia) dengan jarak penanaman yang renggang. Adapun pada beberapa area lain, penutupan vegetasi berkategori kurang baik juga rata-rata disebabkan oleh karena jarak penanaman yang renggang serta tajuk pohon dengan kerapatan yang rendah. Aktivitas pada area ini kurang banyak terlihat. Hal ini terkecuali pada area yang didominasi oleh palem raja dikarenakan 
area tersebut digunakan sebagai akses pengunjung untuk memasuki fasilitas rekreasi sepeda air.

\subsubsection{Kontrol Kelembaban Udara}

Penilaian terhadap unsur kelembaban sangat penting terkait kenyamanan yang ingin diberikan kepada para pengunjung Setu Babakan. Hal tersebut juga sekaligus berpengaruh terhadap mayoritas sebaran pengunjung di dalam memilih Tokasi atau titik-titik tertentu untuk melakukan kegiatan rekreasi. Hasil berdasarkan data primer yang telah diperoleh menunjukkan nilai dari kriteria penilaian sebagai berikut (Tabel 13).

Tabel 13. Kriteria Penilaian Aspek Fungsi Kontrol Kelembaban Udara

\begin{tabular}{|c|c|c|c|c|c|c|c|}
\hline \multirow{2}{*}{ 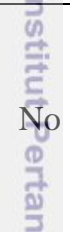 } & \multirow[t]{2}{*}{ Nama Latin } & \multirow[t]{2}{*}{ Nama Lokal } & \multicolumn{3}{|c|}{$\begin{array}{c}\text { Kriteria Fungsi } \\
\text { Kontrol } \\
\text { Kelembaban } \\
\text { Udara }\end{array}$} & \multirow[t]{2}{*}{$\begin{array}{l}\text { Skor } \\
(\%)\end{array}$} & \multirow[t]{2}{*}{ Kategori } \\
\hline & & & K1 & K2 & K3 & & \\
\hline $\bar{y}$ & Acacia longifolia & Akasia & 1 & 1 & 1 & 25.00 & $\mathrm{BU}$ \\
\hline 2 & Adenanthera pavonina & Saga & 1 & 1 & 3 & 41.67 & KB \\
\hline 3 & Antidesma bunius & Buni & 1 & 1 & 1 & 25.00 & BU \\
\hline 4 & Artocarpus altilis & Sukun & 4 & 1 & 3 & 66.67 & BA \\
\hline 5 & Artocarpus heterophyllus & Nangka & 1 & 1 & 2 & 33.33 & BU \\
\hline 6 & Averrhoa carambola & Belimbing & 3 & 1 & 2 & 50.00 & KB \\
\hline 7 & Azadirachta indica & Mimba & 1 & 1 & 2 & 33.33 & $\mathrm{BU}$ \\
\hline 8 & Bauhinia purpurea & Kupu-kupu & 1 & 1 & 3 & 41.67 & KB \\
\hline 9 & Ceiba pentandra & Kapuk randu & 4 & 1 & 3 & 66.67 & BA \\
\hline 10 & Cerbera manghas & Bintaro & 1 & 1 & 2 & 33.33 & $\mathrm{BU}$ \\
\hline 11 & Crateva religiosa & Sawo duren & 1 & 1 & 1 & 25.00 & BU \\
\hline 12 & Cocos nucifera & Kelapa & 1 & 1 & 2 & 33.33 & $\mathrm{BU}$ \\
\hline 13 & Delonix regia & Flamboyan & 2 & 1 & 3 & 50.00 & KB \\
\hline 14 & Dillenia sp. & Sempur & 1 & 1 & 1 & 25.00 & BU \\
\hline 15 & Diospyros blancoi & Bisbul & 1 & 1 & 1 & 25.00 & $\mathrm{BU}$ \\
\hline 16 & Erythrina crista-galli & Dadap merah & 1 & 1 & 4 & 50.00 & KB \\
\hline 17 & Eucalyptus deglupta & Rainbow eucalyptus & 1 & 1 & 4 & 50.00 & $\mathrm{~KB}$ \\
\hline 18 & Feronia lucida & Kawista batu & 2 & 1 & 4 & 58.33 & KB \\
\hline 19 & Ficus benjamina & Beringin & 1 & 1 & 1 & 25.00 & $\mathrm{BU}$ \\
\hline 20 & Ficus binnendykii & Akar ara & 1 & 1 & 1 & 25.00 & $\mathrm{BU}$ \\
\hline 21 & Ficus elastica & Beringin karet & 1 & 1 & 1 & 25.00 & $\mathrm{BU}$ \\
\hline 22 & Ficus lyrata & Biola cantik & 1 & 1 & 1 & 25.00 & $\mathrm{BU}$ \\
\hline 23 & Filicium decipiens & Kerai payung & 1 & 1 & 1 & 25.00 & $\mathrm{BU}$ \\
\hline
\end{tabular}


Tabel 13. Kriteria Penilaian Aspek Fungsi Kontrol Kelembaban Udara (Lanjutan)

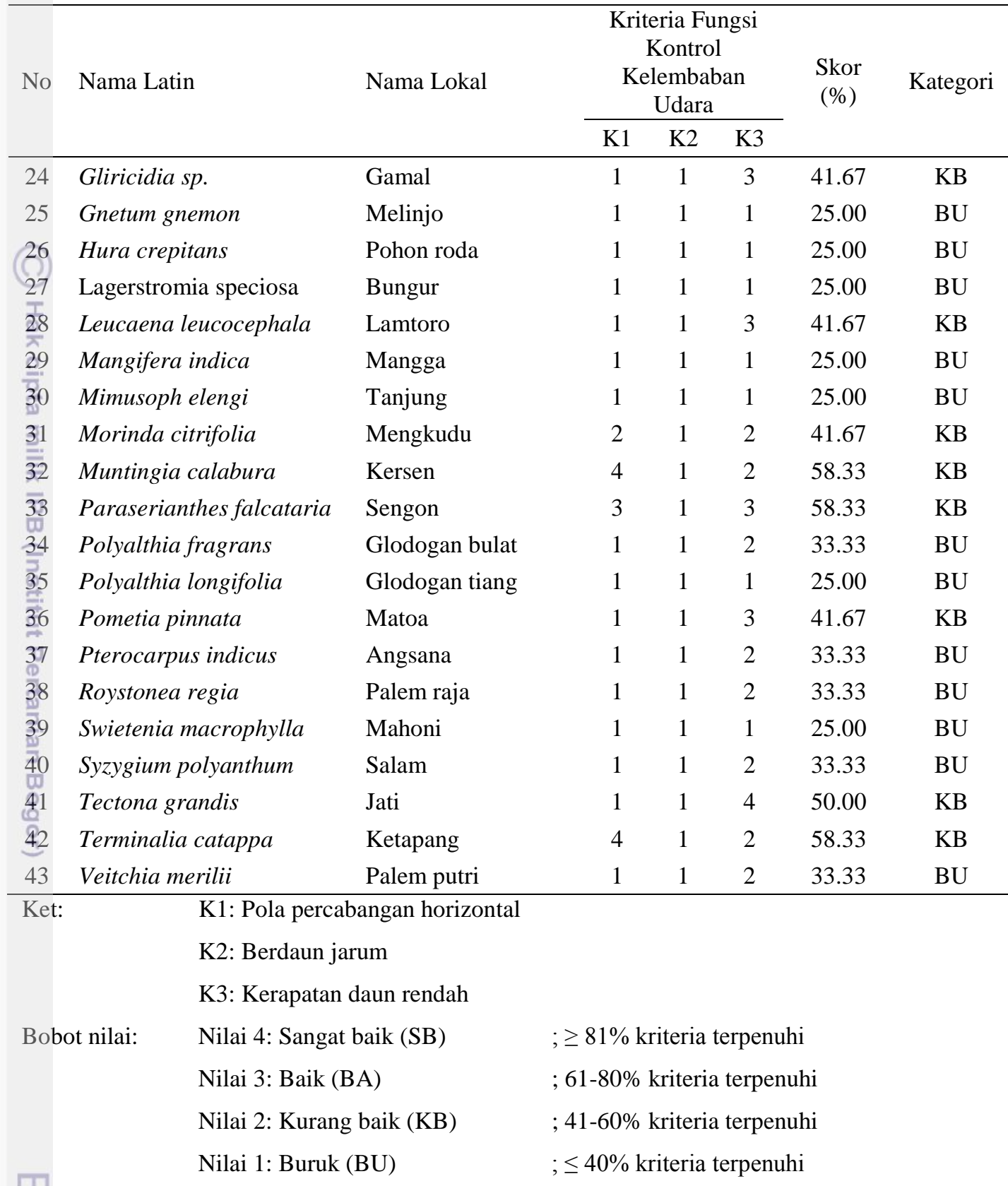

Hasil yang diperoleh dari penilaian terhadap kriteria fisik untuk fungsi kontrol kelembaban udara menunjukkan bahwa pada kawasan ini tidak ditemukan Genis pohon yang termasuk kategori sangat baik. Tidak tercapainya perolehan presentase nilai yang sangat baik disebabkan oleh jumlah pohon dengan pola percabangan horizontal sangatlah sedikit serta tidak ditemukannya pohon berdaun jarum. Adapun jenis-jenis pohon yang termasuk ke dalam kategori baik, yaitu Artocarpus altilis (sukun) dan Ceiba pentandra (kapuk randu) dengan presentase 
sebesar $2.45 \%$ dari total individu pohon dan $4.65 \%$ dari total jenis. Nilai tersebut masih tergolong kecil. Hal tersebut menunjukkan bahwa penutupan vegetasi pada area lingkar danau tidak memberikan kontrol secara maksimal terhadap kelembaban yang berlebih.

Jenis-jenis pohon yang termasuk ke dalam kategori kurang baik, yaitu Adenanthera pavonina (saga), Averrhoa carambola (belimbing), Bauhinia purpurea (bunga kupu-kupu), Delonix regia (flamboyan), Erythrina crista-galli (dadap merah), Eucalyptus deglupta (rainbow eucalyptus), Feronia lucida (kawista batu), Gliricidia sp. (gamal), Leucaena leucocephala (lamtoro), Morinda citrifolia (mengkudu), Muntingia calabura (kersen), Paraserianthes falcataria (sengon), Pometia pinnata (matoa), Tectona grandis (jati), dan Terminalia catappa (ketapang). Presentase yang diperoleh adalah sebesar 29.99\% dari total individu pohon dan $34.88 \%$ total jenis pohon.

Jenis pohon berkategori buruk mendominasi area lingkar danau. Jenisjenis yang termasuk kategori tersebut, yaitu Acacia longifolia (akasia), Antidesma bunius (buni), Artocarpus heterophyllus (nangka), Azadirachta indica (mimba), Cerbera manghas (bintaro), Crateva religiosa (sawo duren), Cocos nucifera (kelapa), Dillenia sp. (sempur), Diospyros blancoi (bisbul), Ficus benjamina (beringin), Ficus binnendykii (akar ara), Ficus elastic (beringin karet), Ficus lyrata (biola cantik), Filicium decipiens (kerai payung), Gnetum gnemon (melinjo), Hura crepitans (pohon roda), Lagerstromia speciosa (bungur), Mangifera indica (mangga), Mimusoph elengi (tanjung), Polyalthia fragrans (glodogan bulat), Polyalthia longifolia (glodogan tiang), Pterocarpus indicus (angsana), Roystonea regia (palem raja), Swietenia macrophylla (mahoni), Syzigium polyanthum (salam), dan Veitchia merilii (palem putri). Penilaian ini (menghasilkan persentase yang cukup tinggi, yaitu sebesar $67.57 \%$ dari total individu pohon dan $60.47 \%$ dari total jenis pohon. Hasil tersebut menunjukkan adanya hubungan berbanding terbalik antara fungsi pohon untuk modifikasi suhu dengan fungsi pohon untuk kontrol kelembaban udara. Hal ini dapat disebabkan Oleh keragaman jenis pohon yang rata-rata memiliki kemampuan tumbuh di daerah dataran rendah, sedangkan pohon-pohon yang secara maksimal mampu memberikan fungsi untuk kontrol kelembaban udara lebih banyak terdapat pada 
daerah dataran tinggi serta area terbuka bagi peruntukan lahan tertentu. Oleh karena itu, penilaian ini menunjukkan bahwa area lingkar danau cenderung lembab. 


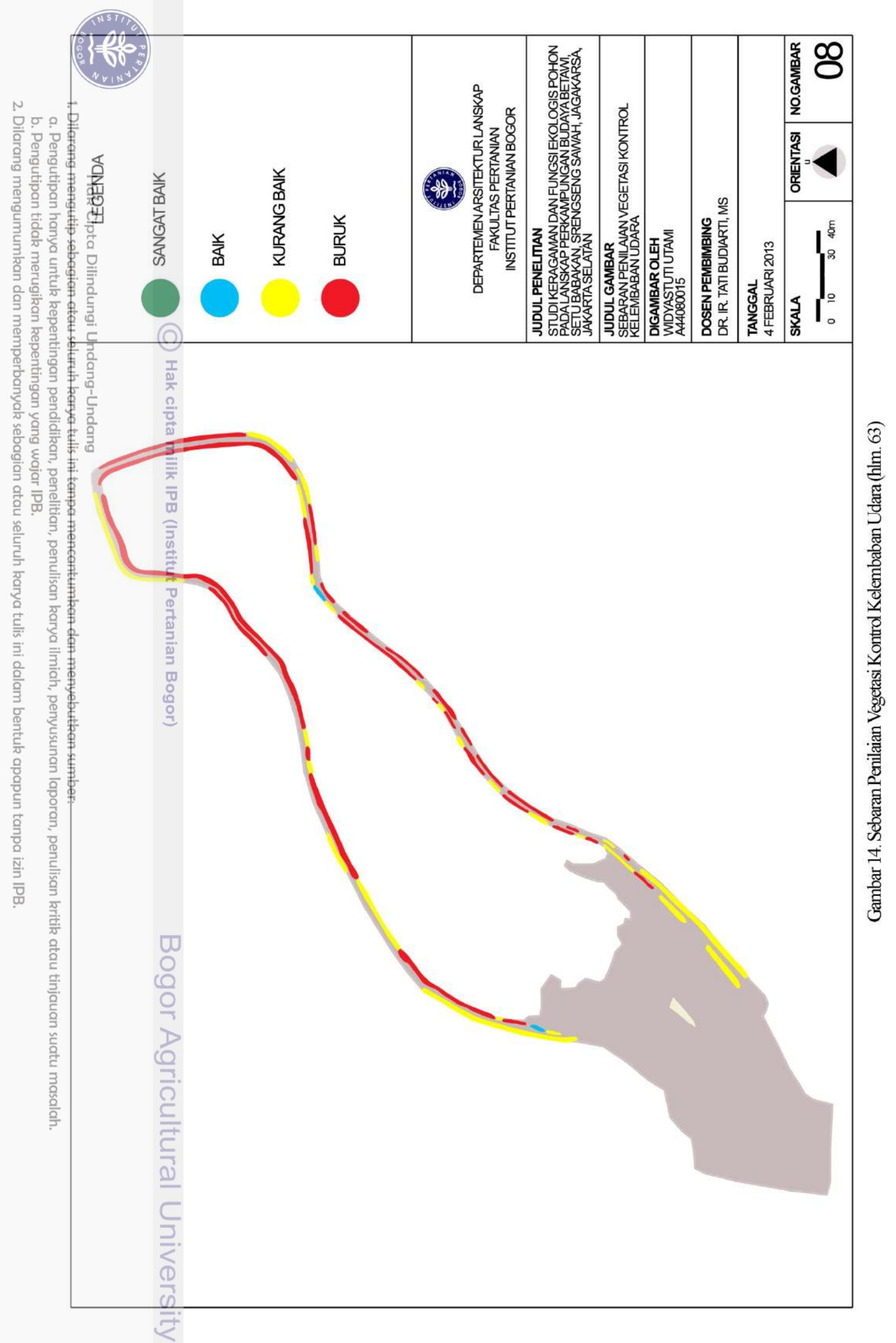


Kelembaban udara di kawasan Setu Babakan tergolong tinggi. Nilai ratarata kelembaban pada tiga tahun terakhir yaitu sebesar 80\%, dengan kelembaban tertinggi tertinggi 96\% (tahun 2009) dan terendah 69\% (tahun 2011). Suhu ratarata sebesar $27.78^{\circ} \mathrm{C}$, dengan suhu tertinggi $35.8^{\circ} \mathrm{C}$ (tahun 2009) dan terendah $22.90^{\circ} \mathrm{C}$ (tahun 2009). Hal tersebut dapat dipengaruhi oleh besarnya jumlah dari keberadaan pohon-pohon melalui naungan yang terbentuk. Nilai kelembaban udara pada area rekreasi Setu Babakan sangat penting untuk diperhatikan guna mengetahui pengaruhnya terhadap kenyamanan pengguna. Melalui rumus THI (Thermal Humidity Index), maka diperoleh sebuah nilai yang dapat menunjukkan tingkat kenyamanan suatu kawasan. Rumus THI adalah sebagai berikut :

$$
\begin{aligned}
& \text { THI }=0.8 \mathrm{~T}+[(\mathrm{RH} \times \mathrm{T}) / 500] \\
& \text { T : suhu udara }\left({ }^{\circ} \mathrm{C}\right) \\
& \text { RH : kelembaban nisbi udara (\%) } \\
& \text { *Nilai } \mathrm{THI}<27 \text { memiliki arti bahwa iklim tersebut nyaman untuk daerah tropis } \\
& \text { (Laurie, } 1985 \text { dalam Purnama, 2007) } \\
& \text { sehingga diperolehlah nilai : } \\
& \mathrm{THI}=0.8\left(27.78^{\circ} \mathrm{C}\right)+\left[\left(80 \times 27.78^{\circ} \mathrm{C}\right) / 500\right]=26.67
\end{aligned}
$$

Angka 26.67 lebih kecil dari batas maksimum nilai kenyamanan sebesar 27. Oleh karena itu, diperoleh hasil bahwa iklim mikro tersebut nyaman untuk daerah tropis, atau secara spesifik disebutkan bahwa kondisi tersebut tergolong nyaman bagi kegiatan rekreasi di Setu Babakan.

Apabila melihat kepada peta sebaran penilaian fungsi ekologis untuk kontrol kelembaban udara, terlihat bahwa secara keseluruhan vegetasi pohon pada area lingkar Setu Babakan kurang baik di dalam mengontrol kelembaban udara. Oleh karena itu, kawasan menjadi cenderung lembab. Area lingkar danau pada (bagian timur dan utara didominasi oleh vegetasi yang tergolong ke dalam kategori buruk, sehingga pada area ini kelembaban udara tergolong tinggi. Bagian selatan dan barat kawasan didominasi oleh vegetasi pohon yang termasuk kategori kurang baik. Sama seperti pada kategori buruk, pohon yang ada pada kategori ini juga kurang baik di dalam mengontrol kelembaban udara. 


\subsubsection{Peredam Kebisingan}

Salah satu tujuan utama pengunjung melakukan kegiatan rekreasi pada kawasan-kawasan yang mengusung konsep alam di tengah kota adalah memperoleh ketenangan. Seperti halnya di Setu Babakan, pengunjung menginginkan suasana yang tenang dan asri, terhindar dari kebisingan yang telah menjadi bagian dari aktivitas dan mobilitas kerja sehari-hari. Melalui penilaian yang dilakukan terhadap jenis-jenis pohon berdasarkan kriteria untuk aspek p⿳亠丷厂

Fabel 14. Kriteria Penilaian Aspek Fungsi Peredam Kebisingan

\begin{tabular}{|c|c|c|c|c|c|c|c|}
\hline \multirow{2}{*}{$\begin{array}{l}\overline{\overline{\bar{Z}}} \\
\overline{\bar{N}} \\
\text { No } \\
\overline{\bar{J}}\end{array}$} & \multirow[t]{2}{*}{ Nama Latin } & \multirow[t]{2}{*}{ Nama Lokal } & \multicolumn{3}{|c|}{$\begin{array}{c}\text { Kriteria Fungsi } \\
\text { Peredam Kebisingan }\end{array}$} & \multirow[t]{2}{*}{$\begin{array}{l}\text { Skor } \\
(\%)\end{array}$} & \multirow[t]{2}{*}{ Kategori } \\
\hline & & & $\mathrm{K} 1$ & $\mathrm{~K} 2$ & K3 & & \\
\hline 1 & Acacia longifolia & Akasia & 4 & 4 & 3 & 91.67 & SB \\
\hline$\frac{5}{2}$ & Adenanthera pavonina & Saga & 2 & 3 & 1 & 50.00 & KB \\
\hline 3 & Antidesma bunius & Buni & 4 & 2 & 2 & 66.67 & $\mathrm{BA}$ \\
\hline 4 & Artocarpus altilis & Sukun & 2 & 3 & 2 & 58.33 & KB \\
\hline 5 & Artocarpus heterophyllus & Nangka & 2 & 3 & 3 & 66.67 & BA \\
\hline 6 & Averrhoa carambola & Belimbing & 2 & 3 & 1 & 50.00 & KB \\
\hline g & Azadirachta indica & Mimba & 3 & 3 & 1 & 58.33 & KB \\
\hline 8 & Bauhinia purpurea & Kupu-kupu & 3 & 1 & 2 & 50.00 & KB \\
\hline 9 & Ceiba pentandra & Kapuk randu & 3 & 3 & 4 & 83.33 & SB \\
\hline 10 & Cerbera manghas & Bintaro & 3 & 2 & 3 & 66.67 & BA \\
\hline 11 & Crateva religiosa & Sawo duren & 3 & 2 & 3 & 66.67 & BA \\
\hline 12 & Cocos nucifera & Kelapa & 2 & 1 & 2 & 41.67 & $\mathrm{~KB}$ \\
\hline 13 & Delonix regia & Flamboyan & 2 & 3 & 1 & 50.00 & BU \\
\hline 14 & Dillenia sp. & Sempur & 3 & 2 & 3 & 66.67 & BA \\
\hline 15 & Diospyros blancoi & Bisbul & 4 & 2 & 3 & 75.00 & BA \\
\hline 16 & Erythrina crista-galli & Dadap merah & 2 & 1 & 1 & 33.33 & BU \\
\hline 17 & Eucalyptus deglupta & Rainbow eucalyptus & 1 & 3 & 1 & 41.67 & KB \\
\hline 18 & Feronia lucida & Kawista batu & 1 & 2 & 2 & 41.67 & KB \\
\hline 19 & Ficus benjamina & Beringin & 4 & 4 & 2 & 83.33 & BA \\
\hline 20 & Ficus binnendykii & Akar ara & 4 & 4 & 3 & 91.67 & SB \\
\hline 21 & Ficus elastica & Beringin karet & 4 & 4 & 4 & 100 & SB \\
\hline 22 & Ficus lyrata & Biola cantik & 4 & 4 & 4 & 100 & SB \\
\hline 23 & Filicium decipiens & Kerai payung & 4 & 3 & 2 & 75.00 & BA \\
\hline 24 & Gliricidia sp. & Gamal & 2 & 3 & 1 & 50.00 & $\mathrm{BU}$ \\
\hline 25 & Gnetum gnemon & Melinjo & 4 & 2 & 2 & 66.67 & BA \\
\hline 26 & Hura crepitans & Pohon roda & 4 & 4 & 2 & 83.33 & SB \\
\hline
\end{tabular}


Tabel 14. Kriteria Penilaian Aspek Fungsi Peredam Kebisingan (Lanjutan)

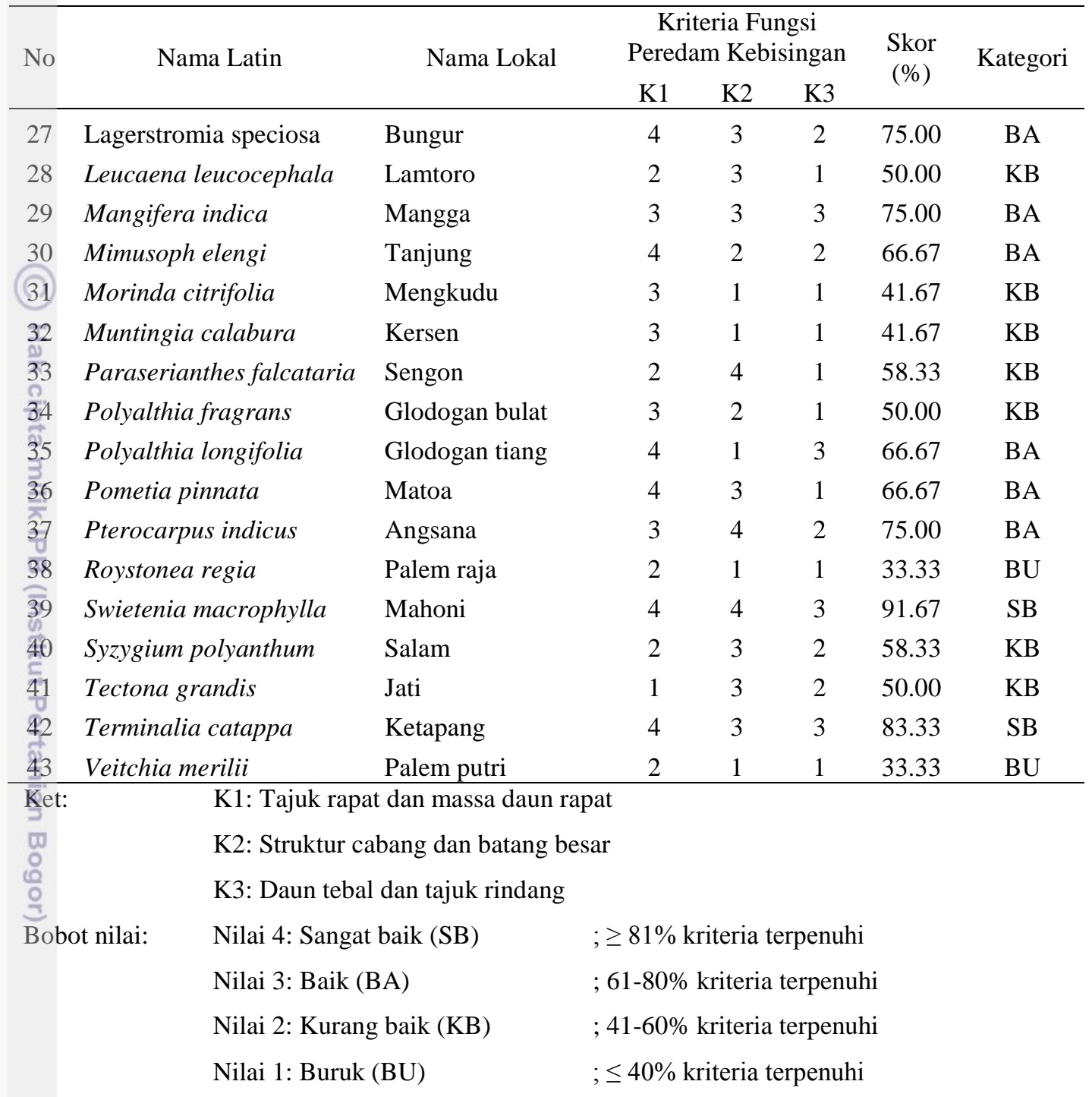

Berdasarkan penilaian yang telah dilakukan, maka diperoleh jenis-jenis pohon yang termasuk ke dalam kategori sangat baik, yaitu Acacia longifolia (akasia), Ceiba pentandra (kapuk randu), Ficus binnendykii (akar ara), Ficus elastica (beringin karet), Ficus lyrata (biola cantik), Hura crepitans (pohon roda), Swietenia macrophylla (mahoni), dan Terminalia catappa (ketapang). Melalui hasil tersebut, didapat presentase sebesar $29.34 \%$ dari total individu pohon dan 18.6\% dari total jenis pohon.

Jenis-jenis pohon yang termasuk ke dalam kategori baik, yaitu Antidesma bunius (buni), Artocarpus heterophyllus (nangka), Cerbera manghas (bintaro), Crateva religiosa (sawo duren), Dillenia sp. (sempur), Diospyros blancoi (bisbul), 
Ficus benjamina (beringin), Filicium decipiens (kerai payung), Gnetum gnemon (melinjo), Lagerstromia speciosa (bungur), Mangifera indica (mangga), Mimusoph elengi (tanjung), Polyalthia longifolia (glodogan tiang), Pometia pinnata (matoa), dan Pterocarpus indicus (angsana). Presentase untuk kategori ini adalah sebesar $34.11 \%$ dari total individu pohon dan $34.88 \%$ dari total jenis pohon.

Melalui penilaian untuk kategori kurang baik, didapat pohon-pohon đengan jenis seperti Adenanthera pavonina (saga), Artocarpus altilis (sukun), Averrhoa carambola (belimbing), Azadirachta indica (mimba), Bauhinia purpurea (kupu-kupu), Cocos nucifera (kelapa), Eucalyptus deglupta (rainbow eucalyptus), Feronia lucida (kawista batu), Leucaena leucocephala (lamtoro), Morinda citrifolia (mengkudu), Muntingia calabura (kersen), Paraserianthes $\overline{\bar{f}}$ lalcataria (sengon), Polyalthia fragrans (glodogan bulat), Syzygium polyanthum (salam), dan Tectona grandis (jati) dengan presentase sebesar 29.6\% dari total individu pohon dan $34.88 \%$ dari total jenis pohon. Adapun untuk kategori buruk terdiri dari Delonix regia (flamboyan), Erythrina crista-galli (dadap merah), Gliricidia sp. (gamal), Roystonea regia (palem raja) dan Veitchia merilii (palem putri) dengan presentase sebesar 6.95\% dari total individu pohon dan $11.63 \%$ dari total jenis pohon. Presentase ini tergolong rendah, jenis pohon yang termasuk di dalamnya pun bukan jenis yang mendominasi kawasan lingkar setu atau dapat dikatakan masih berjumlah sedikit. 


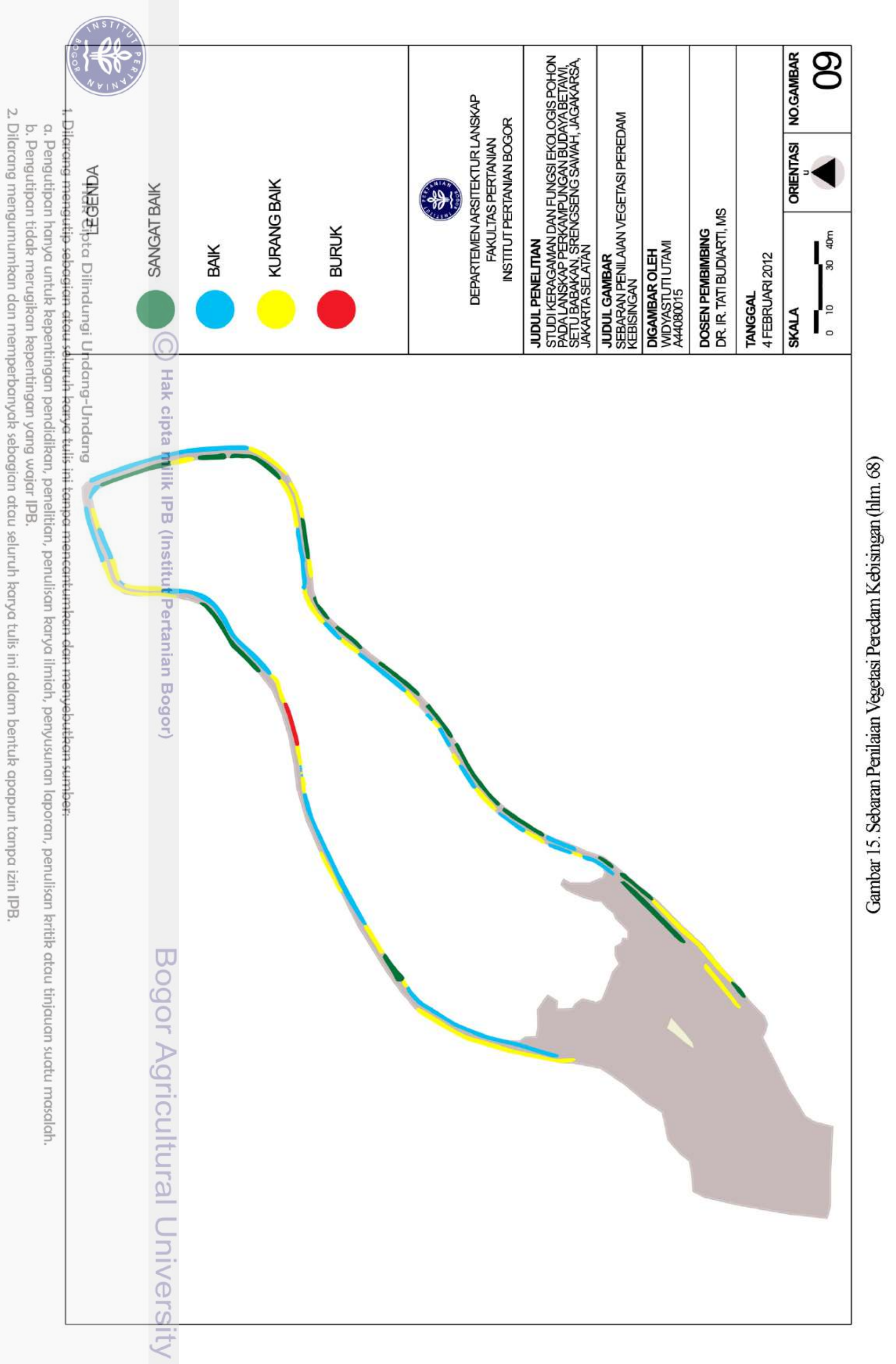


Sumber kebisingan utama yang terdapat pada kawasan adalah bunyi kendaraan sepeda motor yang terbiasa melintas pada jalur lingkar setu yang masuk dari arah pintu gerbang alternatif. Pada hari libur dan hari besar budaya warga Jakarta, ditemukan pula mobil yang masuk ke dalam kawasan. Bagi pemilik rumah di sekitar danau, kebisingan tidak hanya bersumber pada bunyi kendaraan bermotor yang melintas, melainkan juga keramaian yang ditimbulkan Oleh kedatangan pengunjung, terutama pada hari Sabtu dan Minggu di mana pagagelaran budaya biasa dilaksanakan.

Sebagai sebuah kawasan rekreasi bagi masyarakat umum, kawasan Setu Babakan memiliki keunggulan karena memiliki pohon-pohon yang beragam dan beberapa di antaranya tergolong ke dalam jenis pohon tinggi. Apabila dilihat dari ciri morfologisnya, Acacia longifolia (akasia), Ceiba pentandra (kapuk randu), Ficus binnendykii (akar ara), Ficus elastica (beringin karet), Ficus lyrata (biola cantik), Hura crepitans (pohon roda), Swietenia macrophylla (mahoni), dan Ferminalia catappa (ketapang) merupakan jenis-jenis pohon pada area setu yang memiliki potensi sebagai peredam kebisingan dengan fungsi yang paling baik. Adanya variasi ketinggian dari pohon-pohon yang tumbuh tersebut pun menjadi kelebihan dan potensi tersendiri untuk mereduksi kebisingan yang ditimbulkan di sekitar lingkungan. Menurut Herawati (1982), daya serap vegetasi terhadap suara adalah sekitar 6 sampai dengan 8 dBA. Hasil penelitian di Amerika menunjukkan, tanaman berbentuk pohon dan perdu dapat mengurangi kebisingan 5 sampai 8 dBA serta tanaman tinggi dengan tajuk rapat dan tebal akan mengurangi kebisingan 10 dBA. Akan tetapi, tidak seluruh bagian dari sisi area lingkar setu memiliki kerapatan penutupan vegetasi cukup rapat. Pada bagian barat tepi tengah danau (rata-rata ditumbuhi oleh pohon palem raja), vegetasi pohon dengan fungsi (peredam kebisingan kurang dapat memberikan fungsinya dengan baik oleh karena penutupan vegetasi pada area tersebut yang cenderung renggang dan terbuka. Jenis pohon yang tergolong kategori baik mendominasi pada kawasan, akan tetapi secara keseluruhan pohon-pohon pada area lingkar danau memenuhi kriteria fungsi ekologis pohon peredam kebisingan melalui ciri morfologisnya. 


\subsubsection{Penahan Angin}

Aspek kecepatan angin merupakan salah satu hal yang perlu diperhatikan untuk menjaga kenyamanan bagi pengunjung. Kehadiran pohon diharapkan dapat menahan kekuatan angin agar kawasan rekreasi termasuk Setu Babakan secara khususnya nyaman untuk dijadikan tempat bersantai serta tidak mengganggu aktivitas pengguna. Berikut merupakan hasil dari penilaian terhadap aspek fungsi penahan angin berdasarkan kriteria yang telah ditentukan (Tabel 15).

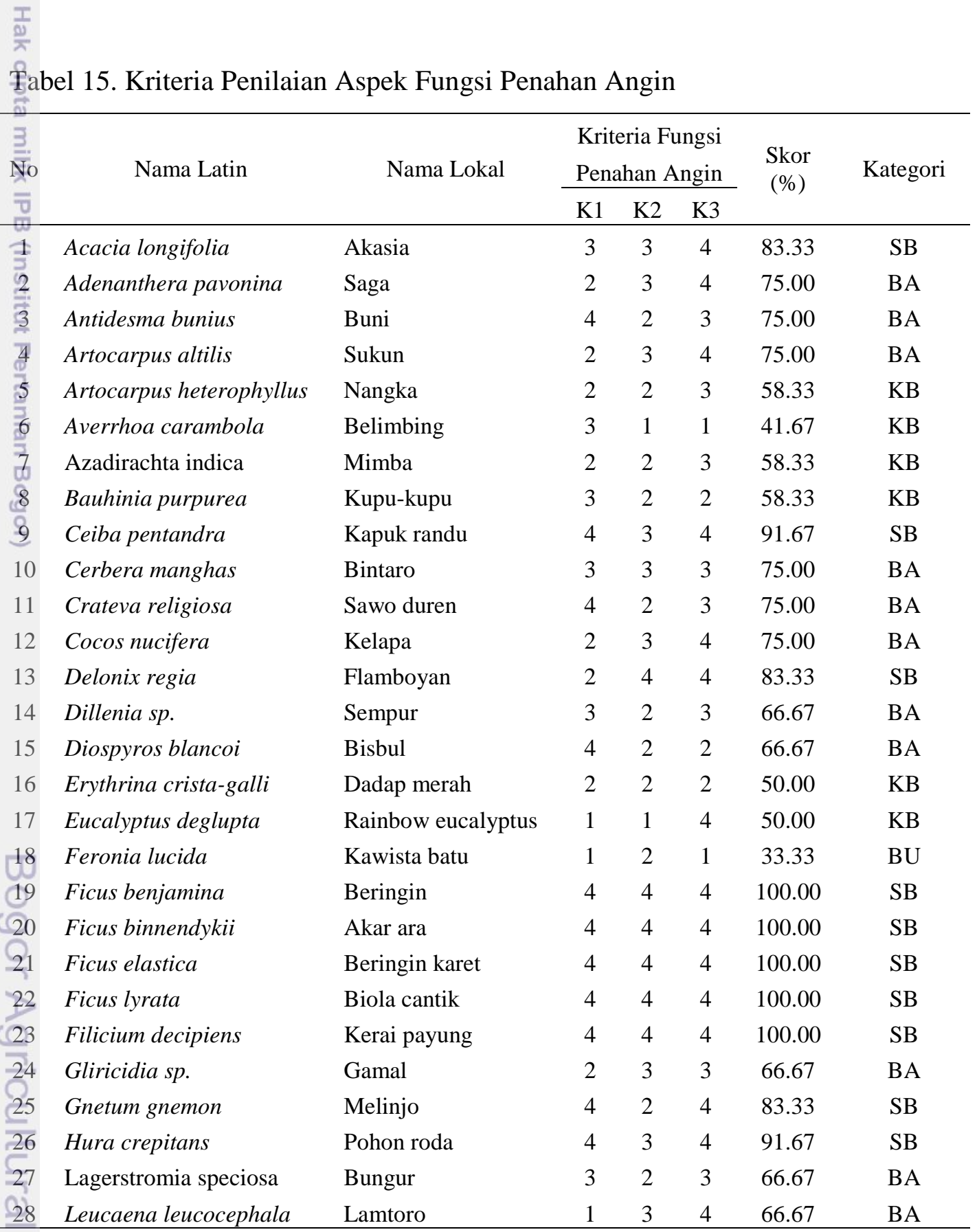


Tabel 15. Kriteria Penilaian Aspek Fungsi Penahan Angin (Lanjutan)

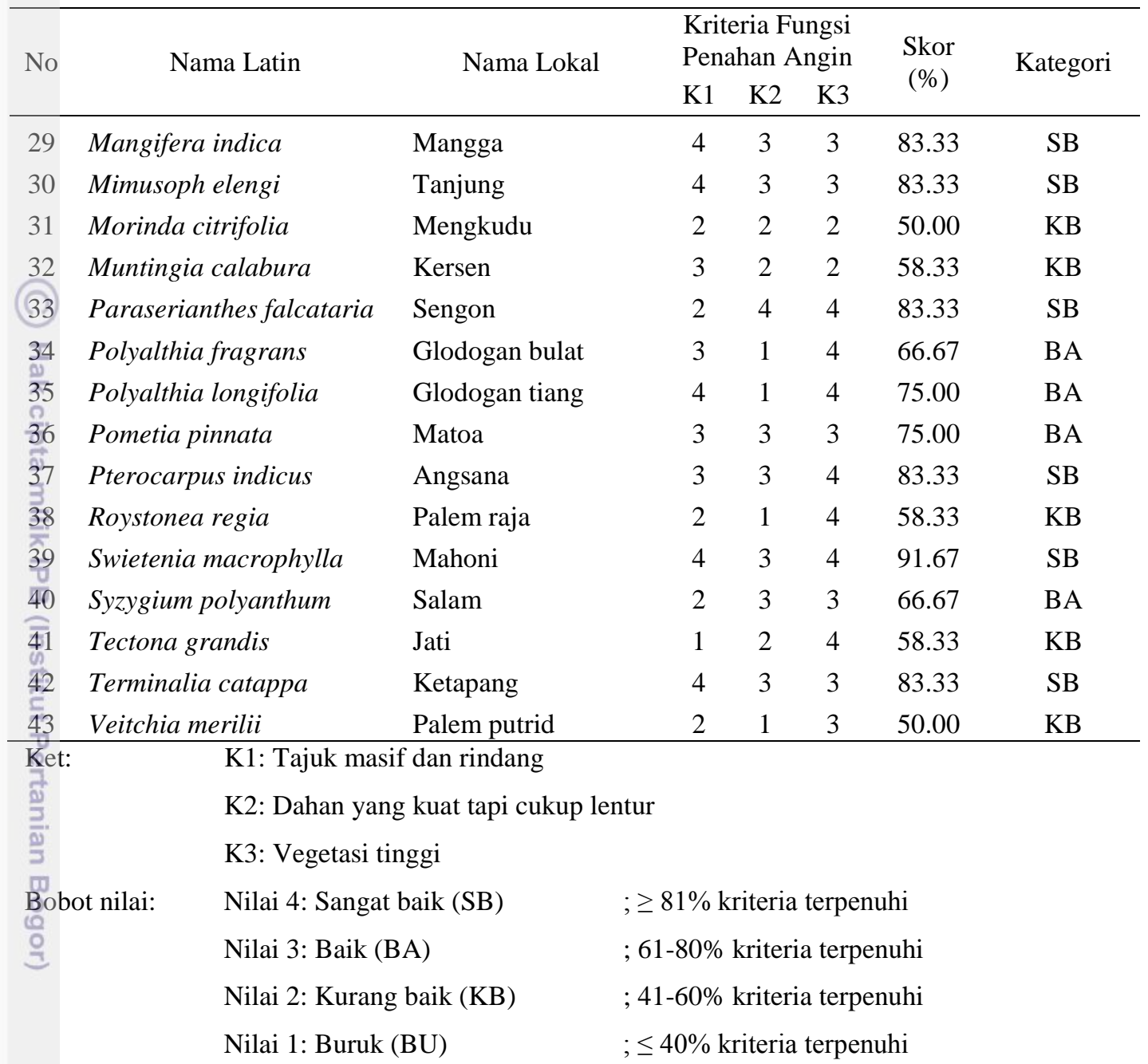

Berdasarkan penilaian terhadap kriteria fungsi ekologis penahan angin, diperoleh jenis-jenis pohon yang termasuk ke dalam kategori sangat baik, yaitu Acacia longifolia (akasia), Ceiba pentandra (kapuk randu), Delonix regia (flamboyan), Ficus benjamina (beringin), Ficus binnendykii (akar ara), Ficus elastic (beringin karet), Filicium decipiens (kerai payung), Ficus lyrata (biola Cantik), Gnetum gnemon (melinjo), Hura crepitans (pohon roda), Mangifera indica (mangga), Mimusoph elengi (tanjung), Paraserianthes falcataria (sengon), Pterocarpus indicus (angsana), Swietenia macrophylla (mahoni), dan Terminalia catappa (ketapang). Hasil tersebut menunjukkan presentase sebesar $43.37 \%$ dari total individu pohon dan $37.21 \%$ dari total jenis pohon.

Pada kategori baik, jenis-jenis pohon yang termasuk ke dalamnya, yaitu Adenanthera pavonina (saga), Antidesma bunius (buni), Artocarpus altilis 
(sukun), Cerbera manghas (bintaro), Crateva religiosa (sawo duren), Cocos nucifera (kelapa), Dillenia sp. (sempur), Diospyros blancoi (bisbul), Gliricidia sp. (gamal), Lagerstromia speciosa (bungur), Leucaena leucocephala (lamtoro), Polyalthia fragrans (glodogan bulat), Polyalthia longifolia (glodogan tiang), Pometia pinnata (matoa), dan Syzigium polyanthum (salam). Pada kategori ini diperoleh presentase sebesar 39.90\% dari total individu pohon dan 34.88\% dari total jenis pohon. Nilai ini hampir sama dengan kategori sangat baik atau dapat đikkatakan hampir seimbang. Selain kedua kategori tersebut, terdapat jenis-jenis pohon yang tergolong ke dalam kategori kurang baik, seperti Artocarpus heterophyllus (nangka), Averrhoa carambola (belimbing), Azadirachta indica (mimba), Bauhinia purpurea (bunga kupu-kupu), Erythrina crista-galli (dadap merah), Eucalyptus deglupta (rainbow eucalyptus), Morinda citrifolia (mengkudu), Muntingia calabura (kersen), Roystonea regia (palem raja), Tectona grandis (jati), dan Veitchia merilii (palem putri), dengan presentase sebesar $16.47 \%$ dari total individu pohon dan $25.58 \%$ dari total jenis pohon. Adapun untuk jenis pohon yang termasuk ke dalam kategori buruk adalah Feronia lucida (Kawista batu), dengan presentase terendah sebesar $0.26 \%$ dari total individu pohon dan $2.33 \%$ dari total jenis pohon.

Jenis-jenis pohon yang termasuk ke dalam kategori sangat baik dan baik merupakan jenis yang paling mendominasi pada kawasan. Presentase nilai yang cukup besar pada keduanya mampu menjelaskan adanya tingkat kemampuan penahan angin kawasan melalui keberadaan pohon-pohon tersebut. Pada kategori kurang baik dan buruk, rata-rata jenis pohon terdiri dari jenis yang tergolong minoritas dan beberapa hanya tumbuh pada titik-titik tertentu di sepanjang lingkar danau. 


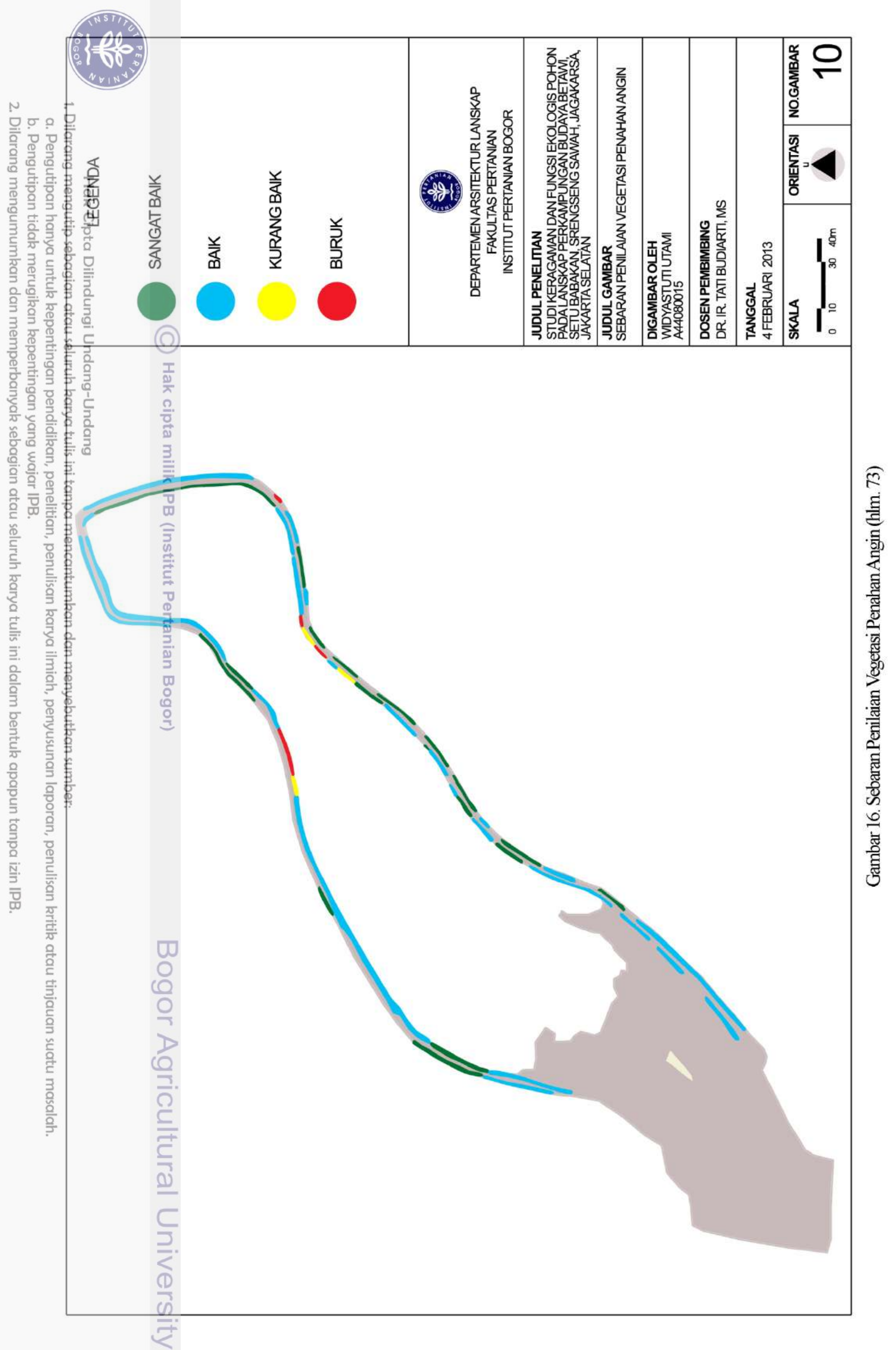


Setu Babakan merupakan sebuah kawasan ruang terbuka hijau yang didominasi oleh luasan permukaan air dan hijauan. Luasan permukaan air tersebut berpotensi terhadap hembusan angin pada kecepatan tertentu yang masuk ke dalam kawasan. Oleh karena itu, analisis terhadap potensi vegetasi pohon sebagai penahan angin dibutuhkan untuk menilai tingkat kenyamanan yang diperoleh pengunjung. Di wilayah Indonesia itu sendiri, angin di siang hari lebih kencang dibandingkan dengan malam hari. Apabila dikaitkan dengan kegiatan rekreasi ȳăng dominan dilakukan pada siang hari, seperti halnya Setu Babakan, maka mianfaat kehadiran vegetasi pohon sangat besar diharapkan.

Pada peta sebaran penilaian fungsi ekologis pohon penahan angin, terlihat bähwa jenis-jenis pohon yang termasuk kategori baik mendominasi kawasan. Secara keseluruhan, kriteria untuk fungsi ekologis pohon penahan angin terpenuhi dengan baik. Akan tetapi, pada bagian barat tepi tengah danau, terdapat area đengan penutupan vegetasi yang rendah, yang didominasi oleh pohon palem raja (Roystonea regia). Area ini digunakan sebagai akses bagi pengunjung untuk memasuki fasilitas sepeda air, sehingga apabila dikaitkan dengan fungsi rekreasi yang ingin diberikan oleh pengelola, area ini memang dibiarkan terbuka, sehingga tịdak cocok digunakan untuk bersantai dan menikmati makan siang.

\subsubsection{Kehadiran Satwa (Burung)}

Keragaman vegetasi pohon yang terdapat pada kawasan lingkar danau Setu Babakan telah mampu menjadi daya tarik tersendiri. Selain sebagai sarana studi bagi pengunjung yang tertarik terhadap jenis-jenis pohon langka yang banyak dibudidayakan di kawasan ini, kehadiran pohon-pohon ini juga mampu menjadikan habitat bagi satwa burung untuk berkembang biak dan mencari (makan. Hadirnya satwa ini diharapkan menjadi salah satu simbol eksistensi nilai ekologis kawasan. Berikut pada Tabel 16 disajikan penilaian berdasarkan kriteria yang telah ditentukan untuk aspek fungsi ekologis di dalam menghadirkan satwa burung. 
Tabel 16. Kriteria Penilaian Aspek Fungsi Menghadirkan Satwa (Burung)

\begin{tabular}{|c|c|c|c|c|c|c|c|}
\hline \multirow[t]{2}{*}{ No } & \multirow[t]{2}{*}{ Nama Latin } & \multirow[t]{2}{*}{ Nama Lokal } & \multicolumn{3}{|c|}{$\begin{array}{l}\text { Kriteria Fungsi } \\
\text { Menghadirkan } \\
\text { Satwa (Burung) }\end{array}$} & \multirow[t]{2}{*}{$\begin{array}{l}\text { Skor } \\
(\%)\end{array}$} & \multirow[t]{2}{*}{ Kategori } \\
\hline & & & K1 & K2 & K3 & & \\
\hline 1 & Acacia longifolia & Akasia & 4 & 1 & 3 & 66.67 & BA \\
\hline 2 & Adenanthera pavonina & Saga & 1 & 1 & 4 & 50.00 & KB \\
\hline 3 & Antidesma bunius & Buni & 4 & 4 & 2 & 83.33 & SB \\
\hline 4 & Artocarpus altilis & Sukun & 1 & 4 & 1 & 50.00 & $\mathrm{~KB}$ \\
\hline 5 & Artocarpus heterophyllus & Nangka & 4 & 4 & 2 & 83.33 & SB \\
\hline & Averrhoa carambola & Belimbing & 4 & 4 & 4 & 100.00 & SB \\
\hline 7 & Azadirachta indica & Mimba & 4 & 4 & 2 & 83.33 & SB \\
\hline 8 & Bauhinia purpurea & Kupu-kupu & 4 & 1 & 4 & 75.00 & BA \\
\hline 9 & Ceiba pentandra & Kapuk randu & 4 & 1 & 4 & 75.00 & BA \\
\hline 10 & Cerbera manghas & Bintaro & 4 & 4 & 2 & 83.33 & SB \\
\hline 11 & Crateva religiosa & Sawo duren & 4 & 4 & 2 & 83.33 & SB \\
\hline 12 & Cocos nucifera & Kelapa & 1 & 4 & 1 & 50.00 & $\mathrm{~KB}$ \\
\hline 13 & Delonix regia & Flamboyan & 4 & 1 & 4 & 75.00 & BA \\
\hline 14 & Dillenia sp. & Sempur & 4 & 4 & 2 & 83.33 & SB \\
\hline 15 & Diospyros blancoi & Bisbul & 4 & 4 & 2 & 83.33 & SB \\
\hline 16 & Erythrina crista-galli & Dadap merah & 4 & 1 & 4 & 75.00 & BA \\
\hline 17 & Eucalyptus deglupta & Rainbow eucalyptus & 1 & 1 & 2 & 33.33 & $\mathrm{BU}$ \\
\hline 18 & Feronia lucida & Kawista batu & 4 & 4 & 3 & 91.67 & SB \\
\hline 19 & Ficus benjamina & Beringin & 4 & 1 & 4 & 75.00 & BA \\
\hline 20 & Ficus binnendykii & Akar ara & 1 & 1 & 3 & 41.67 & $\mathrm{~KB}$ \\
\hline 21 & Ficus elastica & Beringin karet & 1 & 1 & 3 & 41.67 & $\mathrm{~KB}$ \\
\hline 22 & Ficus lyrata & Biola cantik & 1 & 1 & 3 & 41.67 & $\mathrm{~KB}$ \\
\hline 23 & Filicium decipiens & Kerai payung & 1 & 1 & 2 & 33.33 & $\mathrm{BU}$ \\
\hline 24 & Gliricidia sp. & Gamal & 4 & 4 & 3 & 91.67 & SB \\
\hline 25 & Gnetum gnemon & Melinjo & 4 & 4 & 2 & 83.33 & SB \\
\hline 26 & Hura crepitans & Pohon roda & 4 & 4 & 3 & 91.67 & SB \\
\hline 27 & Lagerstromia speciosa & Bungur & 4 & 4 & 3 & 91.67 & SB \\
\hline 28 & Leucaena leucocephala & Lamtoro & 1 & 4 & 4 & 75.00 & BA \\
\hline 29 & Mangifera indica & Mangga & 4 & 4 & 2 & 83.33 & SB \\
\hline & Mimusoph elengi & Tanjung & 4 & 4 & 2 & 83.33 & SB \\
\hline & Morinda citrifolia & Mengkudu & 1 & 4 & 1 & 50.00 & $\mathrm{~KB}$ \\
\hline & Muntingia calabura & Kersen & 4 & 4 & 4 & 100.00 & SB \\
\hline & Paraserianthes falcataria & Sengon & 4 & 4 & 4 & 100.00 & SB \\
\hline & Polyalthia fragrans & Glodogan bulat & 4 & 4 & 2 & 83.33 & SB \\
\hline & Polyalthia longifolia & Glodogan tiang & 4 & 4 & 2 & 83.33 & SB \\
\hline & Pometia pinnata & Matoa & 4 & 4 & 2 & 58.33 & KB \\
\hline & Pterocarpus indicus & Angsana & 4 & 1 & 3 & 91.67 & SB \\
\hline 38 & Roystonea regia & Palem raja & 1 & 1 & 1 & 25.00 & BU \\
\hline
\end{tabular}


Tabel 16. Kriteria Penilaian Aspek Fungsi Menghadirkan Satwa (Burung) (Lanjutan)

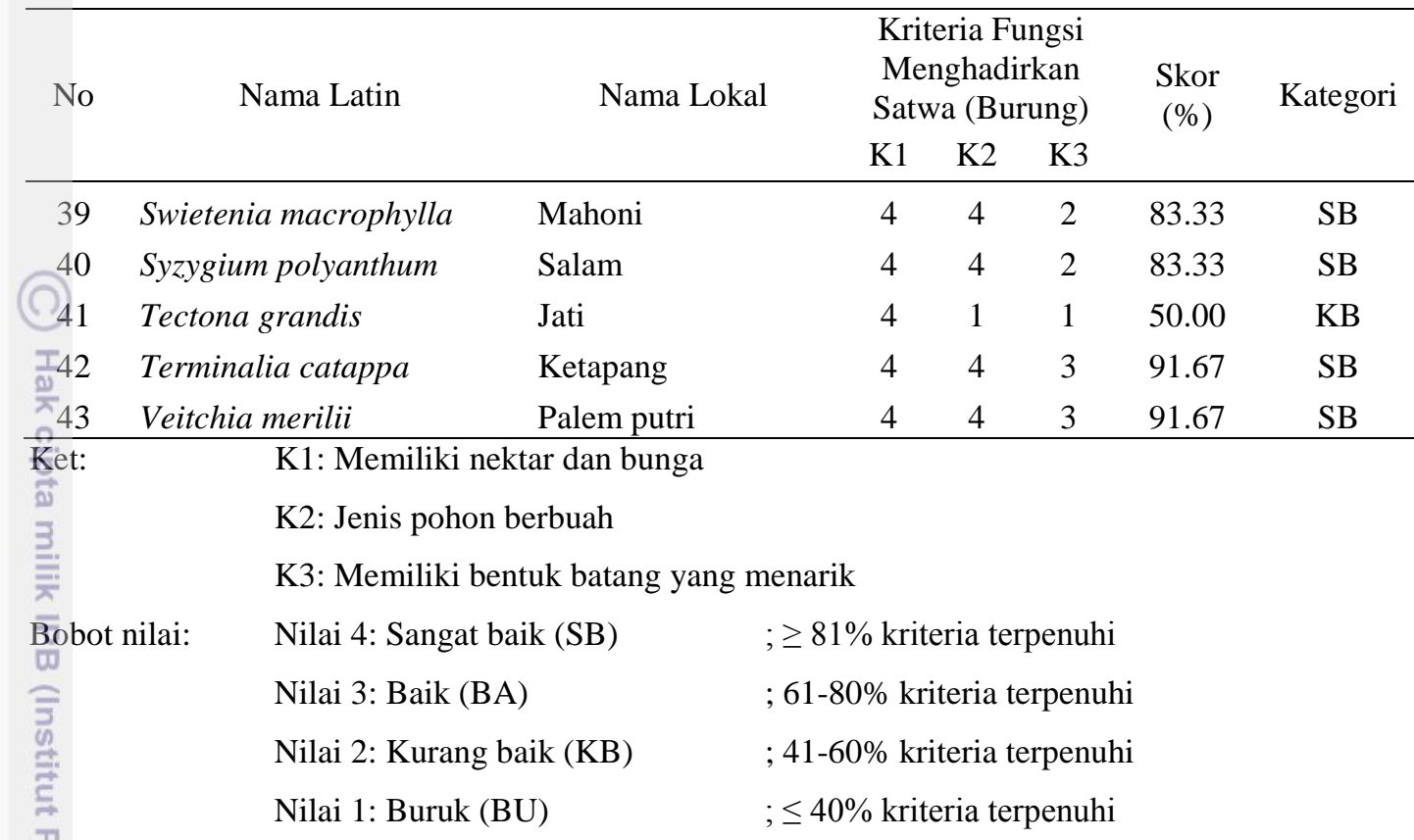

Berdasarkan penilaian di atas, diperoleh hasil berupa jenis-jenis pohon yang termasuk kategori sangat baik, yaitu Antidesma bunius (buni), Artocarpus heterophyllus (nangka), Averrhoa carambola (belimbing), Azadirachta indica (mimba), Cerbera manghas (bintaro), Crateva religiosa (sawo duren), Dillenia sp. (sempur), Diospyros blancoi (bisbul), Feronia lucida (kawista batu), Gliricidia sp. (gamal), Gnetum gnemon (melinjo), Hura crepitans (pohon roda), Lagerstromia speciosa (bungur), Mangifera indica (mangga), Mimusoph elengi (tanjung), Muntingia calabura (kersen), Paraserianthes falcataria (sengon), Polyalthia fragrans (glodogan bulat), Polyalthia longifolia (glodogan tiang), Pterocarpus indicus (angsana), Swietenia macrophylla (mahoni), Syzygium (polyanthum (salam), Terminalia catappa (ketapang) dan Veitchia merilii (palem putri). Kategori ini mendominasi dengan presentase sebesar $72.33 \%$ dari total individu pohon dan $55.81 \%$ dari total jenis pohon. Oleh karena itu, lokasi ini dapat dikatakan baik bagi habitat satwa seperti burung untuk mencari makan, tempat tinggal dan berkembang biak pada pohon-pohon dengan fungsinya masing-masing. 
Selain pohon dengan kategori sangat baik, terdapat pula pohon yang termasuk ke dalam kategori baik, yaitu Acacia longifolia (akasia), Bauhinia purpurea (kupu-kupu), Ceiba pentandra (kapuk randu), Delonix regia (flamboyan), Erythrina crista-galli (dadap merah), Ficus benjamina (beringin), dan Leucaena leucocephala (lamtoro) dengan presentase sebesar 15.83\% dari total individu pohon dan $16.28 \%$ dari total jenis pohon. Adapun pada kategori kurang baik, terdapat Adenanthera pavonina (saga), Artocarpus altilis (sukun), Ėocos nucifera (kelapa), Ficus binnendykii (akar ara), Ficus elastica (beringin karet), Ficus lyrata (biola cantik), Morinda citrifolia (mengkudu), Pometia pinnata (matoa), dan Tectona grandis (jati), dengan presentase sebesar 9.27\% dari tötal individu pohon dan $20.93 \%$ dari total jenis pohon. Pada kategori buruk, terdapat Eucalyptus deglupta (rainbow eucalyptus), Filicium decipiens (kerai payung), dan Roystonea regia (palem raja), dengan presentase sebesar $2.57 \%$ dari tôtal individu pohon dan $6.98 \%$ dari total jenis pohon. 


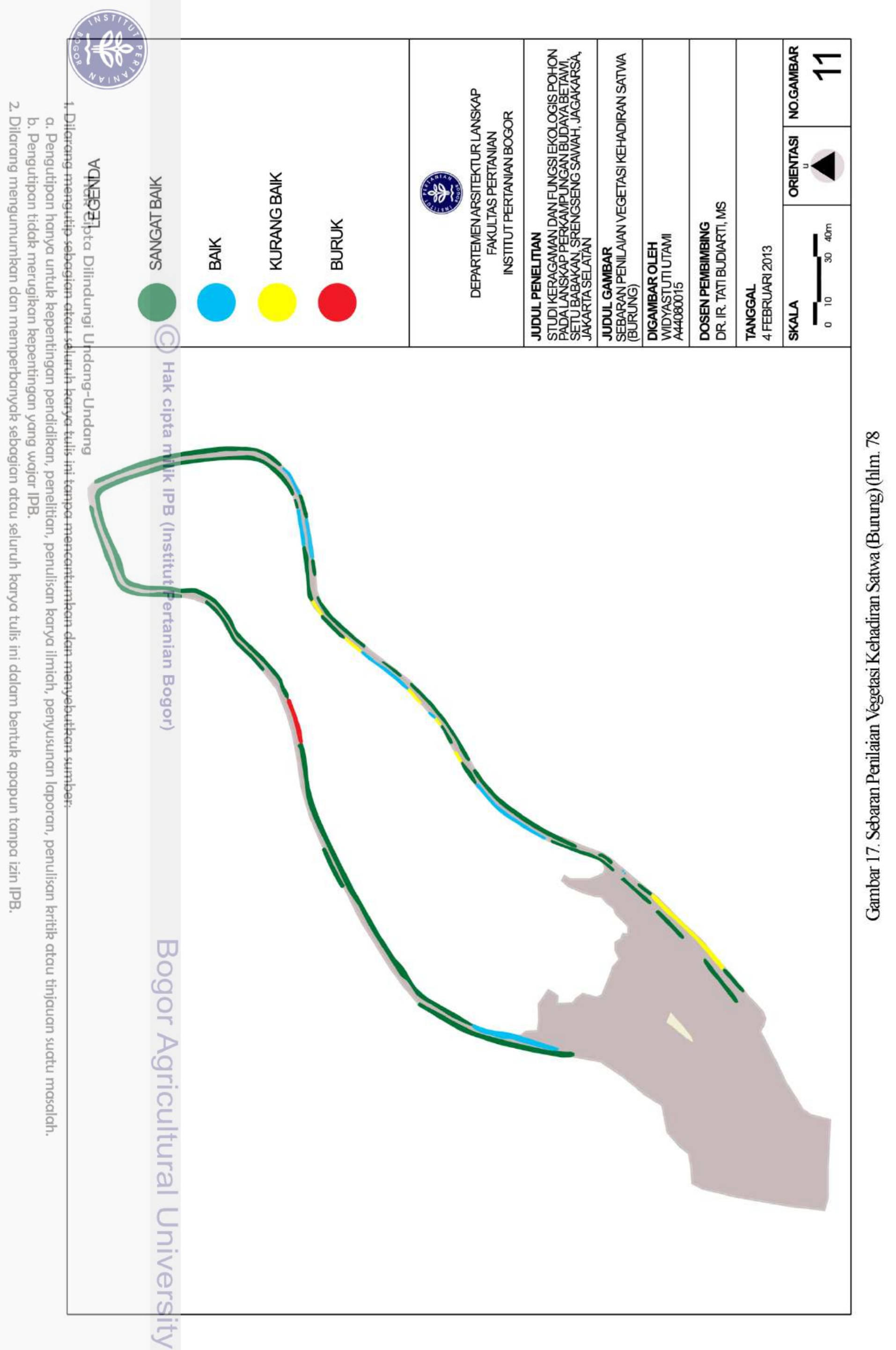


Keragaman jenis, arsitektur tajuk dan batang, serta strata vegetasi yang ada telah menjadi habitat yang baik bagi kehidupan satwa burung. Burung-burung yang ditemukan pada kawasan lingkar setu biasa ditemukan pada jenis-jenis pohon seperti beringin (Ficus benjamina), bunga kupu-kupu (Bauhinia purprea), flamboyan (Delonix regia) dan dadap merah (Erythrina crista-galli). Masingmasing pohon memiliki fungsi tersendiri bagi satwa burung untuk hidup.

Menurut Olive (2011) terdapat beberapa tipe tumbuhan yang penting bagi habitat burung. Pohon-pohon tersebut di antaranya jenis yang berdaun jarum yang disukai burung pemukiman. Selain itu, adapun pohon rindang seperti beringin, kapuk, dan sengon oleh karena fungsinya untuk melindungi burung dari panas Sinnar matahari. Adapun jenis lain dari polong-polongan seperti angsana, akasia, asoka dan dadap yang mampu menghadirkan biji-bijian selain daripada fungsinya untuk perlindungan. Pohon penghasil nektar, tanaman hias, tanaman berbunga, đan pohon penghasil buah juga mampu menarik perhatian burung.

Pada peta sebaran fungsi ekologis pohon untuk kehadiran satwa burung, terlihat bahwa jenis-jenis pohon yang termasuk dalam kategori sangat baik miendominasi kawasan lingkar danau secara merata. Akan tetapi, bukan berarti bahwa kondisi berdasarkan penilaian dari kriteria yang diberikan menunjukkan peningkatan jumlah burung yang singgah dan dapat ditemukan. Burung sangat menyukai area yang tenang, sehingga pada beberapa titik pada kawasan, seperti yang biasa digunakan untuk meja dan kursi makan dalam jumlah yang besar, satwa ini cukup sulit ditemukan, kecuali burung gereja yang biasa mencari makan di atas tanah. Pada kawasan ini, burung-burung lebih mudah ditemukan pada area bagian barat, oleh karena aktivitas pengunjung pada area ini lebih rendah dibandingkan aktivitas pengunjung pada bagian timur. Selain itu, area ini juga (terkoneksi dengan kebun-kebun yang dimiliki oleh warga di sekitar danau, sehingga alur vegetasi (sebagai stepping stone bagi satwa burung) tidak terputus hanya pada area lingkar danau. Jenis-jenis pohon di bagian barat pun cukup beragam sebagai tempat mencari makan, seperti bunga kupu-kupu (Bauhinia purpurea), beringin (Ficus benjamina),bungur (Lagerstromia speciosa), dan kersen (Muntingia calabura). 


\subsection{Analisis Fungsi Ekologis Pohon pada Pekarangan}

Penilaian dilakukan terhadap fungsi vegetasi pohon pada sepuluh contoh pekarangan di Setu Babakan berdasarkan kriteria masing-masing, yaitu kategori sangat baik (SB), kategori baik (BA), kategori kurang baik (KB), dan kategori buruk (BU). Tahapan ini dipaparkan melalui tabel dan penjelasan secara deskriptif.

\subsubsection{Modifikasi Suhu sebagai Penaung}

Kehadiran pohon penting bagi sebuah tempat tinggal bagi kenyamanan untuk melindunginya dari sinar matahari, sehingga udara di dalam rumah menjadi lébih sejuk secara alami. Berikut merupakan hasil dari penilaian yang dilakukan terrhadap jenis-jenis pohon pada sepuluh contoh pekarangan rumah yang tertera pada Tabel 17.

Fabel 17. Kriteria Penilaian Aspek Fungsi Modifikasi Suhu sebagai Penaung (Pekarangan)

\begin{tabular}{|c|c|c|c|c|c|c|c|}
\hline \multirow[t]{2}{*}{$\begin{array}{l}0 \\
\circ \\
৫ \\
\text { No }\end{array}$} & \multirow[t]{2}{*}{ Nama Latin } & \multirow[t]{2}{*}{ Nama Lokal } & \multicolumn{3}{|c|}{$\begin{array}{c}\text { Kriteria Fungsi } \\
\text { Modifikasi } \\
\text { Suhu } \\
\end{array}$} & \multirow[t]{2}{*}{$\begin{array}{l}\text { Skor } \\
(\%)\end{array}$} & \multirow[t]{2}{*}{ Kategori } \\
\hline & & & $\mathrm{K} 1$ & K2 & K3 & & \\
\hline 1 & Annona squamosa & Srikaya & 1 & 2 & 3 & 50.00 & KB \\
\hline 2 & Areca catechu & Pinang & 4 & 1 & 1 & 50.00 & KB \\
\hline 3 & $\begin{array}{l}\text { Artocarpus } \\
\text { heterophyllus }\end{array}$ & Nangka & 1 & 2 & 3 & 50.00 & KB \\
\hline 4 & Averrhoa carambola & Belimbing & 1 & 1 & 3 & 41.67 & KB \\
\hline 5 & Cananga odorata & Kenanga & 4 & 2 & 3 & 75.00 & BA \\
\hline 6 & Citrus maxima & Jeruk bali & 1 & 4 & 3 & 66.67 & BA \\
\hline 7 & Coryota mitis & Palem ekor ikan & 1 & 1 & 3 & 41.67 & KB \\
\hline 8 & Crateva religiosa & Sawo duren & 4 & 3 & 4 & 91.67 & SB \\
\hline 9 & Dimocarpus longan & Lengkeng & 4 & 4 & 4 & 100.00 & SB \\
\hline 10 & Durio zibethinus & Durian montong & 1 & 3 & 2 & 50.00 & $\mathrm{~KB}$ \\
\hline 11 & Feronia lucida & Kawista batu & 1 & 1 & 1 & 25.00 & $\mathrm{BU}$ \\
\hline 12 & Ficus benjamina & Beringin & 4 & 4 & 4 & 100.00 & SB \\
\hline 13 & Flacourtia rukam & Rukem & 4 & 3 & 4 & 91.67 & SB \\
\hline 14 & Gnetum gnemon & Melinjo & 1 & 1 & 4 & 50.00 & KB \\
\hline 15 & Lansium domesticum & Duku condet & 4 & 3 & 4 & 91.67 & SB \\
\hline 16 & Mangifera indica & Mangga (apel) & 1 & 2 & 4 & 58.33 & KB \\
\hline 17 & Mangifera indica & Mangga (arum manis) & 1 & 3 & 4 & 66.67 & BA \\
\hline 18 & Mangifera indica & Mangga (okyong) & 1 & 2 & 4 & 58.33 & KB \\
\hline
\end{tabular}


Tabel 17. Kriteria Penilaian Aspek Fungsi Modifikasi Suhu (Pekarangan) (Lanjutan)

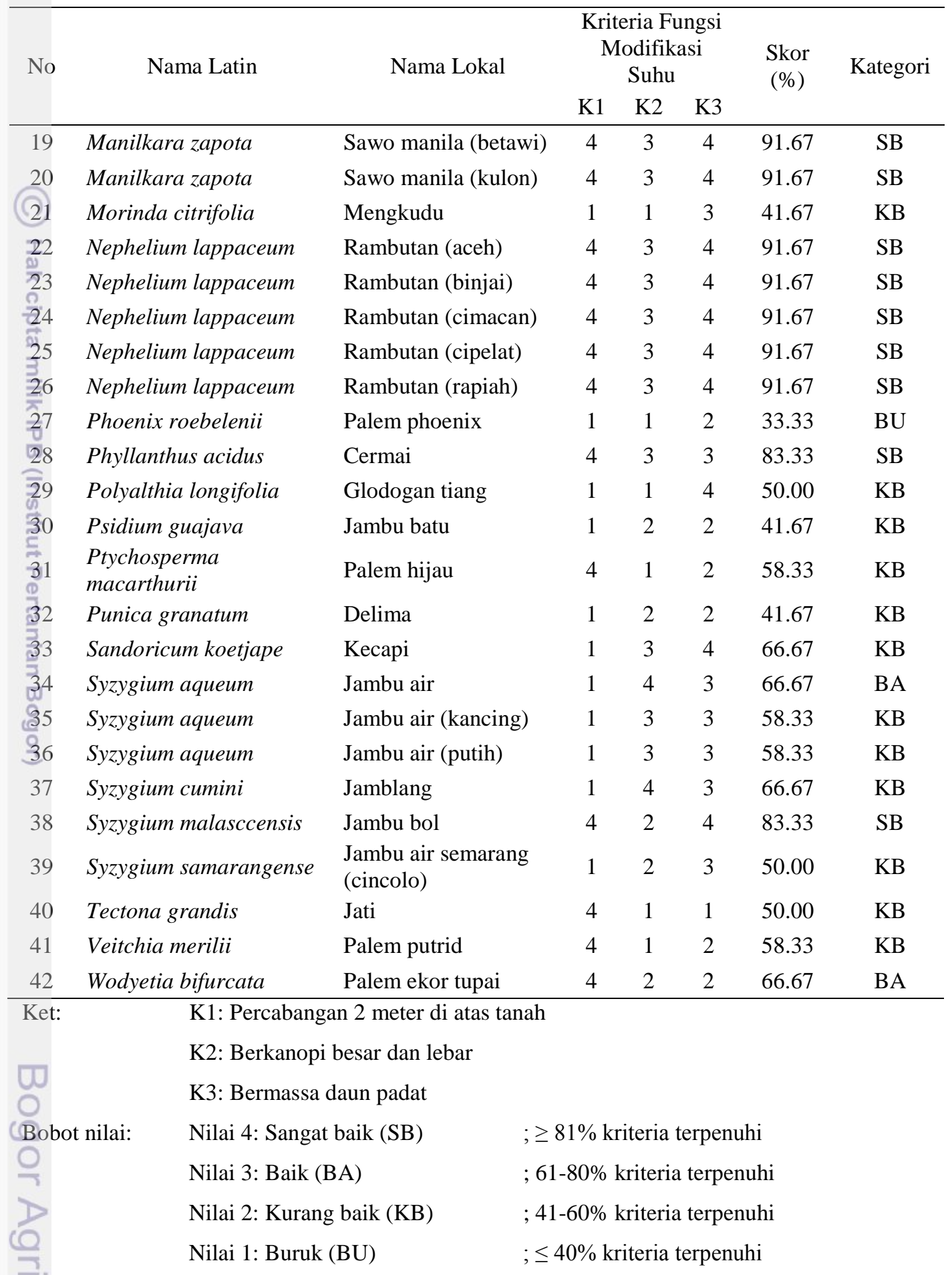

Melalui evaluasi yang dilakukan terhadap pohon berdasarkan fungsinya untuk modifikasi suhu, diperoleh hasil bahwa yang tergolong dalam kategori sangat baik adalah Crateva religiosa (sawo duren), Dimocarpus longan 
(lengkeng), Ficus benjamina (beringin), Flacourtia rukam (rukem), Lansium domesticum (duku condet), Manilkara zapota (sawo manila (betawi)), Manilkara zapota (sawo manila (kulon)), Nephelium lappaceum (rambutan (aceh)), Nephelium lappaceum (rambutan (binjai)), Nephelium lappaceum (rambutan (cimacan)), Nephelium lappaceum (rambutan (cipelat)), Nephelium lappaceum (rambutan (rapiah)), Phyllanthus acidus (cermai), dan Syzygium malasccensis (jambu bol). Kategori ini memiliki presentase sebesar $26.79 \%$ dari total individu pohon dan 33.33\% dari total jenis pohon.

Jenis-jenis pohon pada kategori baik, yaitu Cananga odorata (kenanga), Ǵitrus maxima (jeruk bali), Mangifera indica (mangga (arum manis)), Syzygium 立queum (jambu air), dan Wodyetia bifurcate (palem ekor tupai). Kategori ini memiliki presentase sebesar $21.43 \%$ dari total individu pohon dan $11.90 \%$ dari total jenis pohon. Adapun jensi pohon yang tergolong ke dalam kategori kurang baik, yaitu Annona squamosa (srikaya), Areca catechu (pinang), Artocarpus heterophyllus (nangka), Averrhoa carambola (belimbing), Coryota mitis (palem èkor tupai), Durio zibethinus (durian montong), Gnetum gnemon (melinjo), Mangifera indica (mangga (apel)), Mangifera indica (mangga (okyong)), Ṃorinda citrifolia (mengkudu), Polyalthia longifolia (glodogan tiang), Psidium guajava (jambu batu), Ptychosperma macarthurii (palem hijau), Punica granatum (delima), Sandoricum koetjape (kecapi), Syzygium aqueum (jambu air (kancing)), Syzygium aqueum (jambu air (putih)), Syzygium cumini (jamblang), dan Syzygium samarangense (jambu air semarang (cincolo)), Tectona grandis (jati), dan Veitchia merilii (palem putri). Kategori ini mendominasi dengan presentase sebesar 53.57\% dari total individu pohon dan 50\% dari total jenis pohon. Pada kategori kurang baik, rata-rata jenis pohon tergolong tanaman buah produksi dan cjuga varietas unggul dari jenis tertentu. Beberapa di antaranya juga terdapat jenis tanaman hias untuk pekarangan. Adapun jenis pohon pada kategori buruk, yaitu Feronia lucida (kawista batu) dan Phoenix roebelenii (Palem phoenix) dengan presentase sebesar $1.79 \%$ dari total individu pohon dan $4.76 \%$ dari total jenis pohon. 


\subsubsection{Kontrol Kelembaban Udara}

Tingkat kelembaban udara sangat penting untuk mengetahui nilai kenyamanan, terutama bagi pemilik rumah. Pada pekarangan, luas lahan juga memiliki pengaruh terhadap jumlah dan jenis pohon yang dapat ditanam. Hal ini kemudian berhubungan terhadap tingkat kelembaban yang berbeda-beda pada masing-masing rumah tergantung dari jumlah, jenis dan luas lahan pekarangan yang dimiliki. Berikut merupakan hasil dari evaluasi terhadap fungsi ekologis pohon untuk kontrol kelembaban udara yang tertera pada Tabel 18.

Eabel 18. Kriteria Penilaian Aspek Fungsi Kontrol Kelembaban Udara (Pekarangan)

\begin{tabular}{|c|c|c|c|c|c|c|c|}
\hline \multirow{2}{*}{ 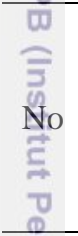 } & \multirow[t]{2}{*}{ Nama Latin } & \multirow[t]{2}{*}{ Nama Lokal } & \multicolumn{3}{|c|}{$\begin{array}{c}\text { Kriteria Fungsi } \\
\text { Kontrol } \\
\text { Kelembaban } \\
\text { Udara } \\
\end{array}$} & \multirow[t]{2}{*}{$\begin{array}{l}\text { Skor } \\
\text { (\%) }\end{array}$} & \multirow[t]{2}{*}{ Kategori } \\
\hline & & & $\mathrm{K} 1$ & $\mathrm{~K} 2$ & K3 & & \\
\hline 1 & Annona squamosa & Srikaya & 1 & 1 & 2 & 33.33 & $\mathrm{BU}$ \\
\hline 2 & Areca catechu & Pinang & 1 & 1 & 2 & 33.33 & $\mathrm{BU}$ \\
\hline 3 & Artocarpus heterophyllus & Nangka & 1 & 1 & 2 & 33.33 & BU \\
\hline 4 & Averrhoa carambola & Belimbing & 3 & 1 & 2 & 50.00 & KB \\
\hline 5 & Cananga odorata & Kenanga & 1 & 1 & 1 & 25.00 & $\mathrm{BU}$ \\
\hline 6 & Citrus maxima & Jeruk bali & 1 & 1 & 1 & 25.00 & BU \\
\hline 7 & Coryota mitis & Palem ekor ikan & 1 & 1 & 1 & 25.00 & $\mathrm{BU}$ \\
\hline 8 & Crateva religiosa & Sawo duren & 1 & 1 & 1 & 25.00 & BU \\
\hline 9 & Dimocarpus longan & Lengkeng & 1 & 1 & 1 & 25.00 & $\mathrm{BU}$ \\
\hline 10 & Durio zibethinus & Durian montong & 1 & 1 & 3 & 41.67 & $\mathrm{BU}$ \\
\hline 11 & Feronia lucida & Kawista batu & 2 & 1 & 4 & 58.33 & $\mathrm{~KB}$ \\
\hline 12 & Ficus benjamina & Beringin & 1 & 1 & 1 & 25.00 & $\mathrm{BU}$ \\
\hline 13 & Flacourtia rukam & Rukem & 1 & 1 & 1 & 25.00 & $\mathrm{BU}$ \\
\hline 14 & Gnetum gnemon & Melinjo & 1 & 1 & 1 & 25.00 & $\mathrm{BU}$ \\
\hline 15 & Lansium domesticum & Duku condet & 1 & 1 & 1 & 25.00 & BU \\
\hline 16 & Mangifera indica & Mangga (apel) & 1 & 1 & 1 & 25.00 & BU \\
\hline 17 & Mangifera indica & Mangga (arum manis) & 1 & 1 & 1 & 25.00 & $\mathrm{BU}$ \\
\hline 18 & Mangifera indica & Mangga (okyong) & 1 & 1 & 1 & 25.00 & $\mathrm{BU}$ \\
\hline 19 & Manilkara zapota & Sawo manila (betawi) & 1 & 1 & 1 & 25.00 & $\mathrm{BU}$ \\
\hline 20 & Manilkara zapota & Sawo manila (kulon) & 1 & 1 & 1 & 25.00 & $\mathrm{BU}$ \\
\hline 21 & Morinda citrifolia & Mengkudu & 2 & 1 & 2 & 41.67 & KB \\
\hline 22 & Nephelium lappaceum & Rambutan (aceh) & 1 & 1 & 1 & 25.00 & $\mathrm{BU}$ \\
\hline 23 & Nephelium lappaceum & Rambutan (binjai) & 1 & 1 & 1 & 25.00 & $\mathrm{BU}$ \\
\hline 24 & Nephelium lappaceum & Rambutan (cimacan) & 1 & 1 & 1 & 25.00 & BU \\
\hline 25 & Nephelium lappaceum & Rambutan (cipelat) & 1 & 1 & 1 & 25.00 & BU \\
\hline
\end{tabular}


Tabel 18. Kriteria Penilaian Aspek Fungsi Kontrol Kelembaban Udara (Pekarangan) (Lanjutan)

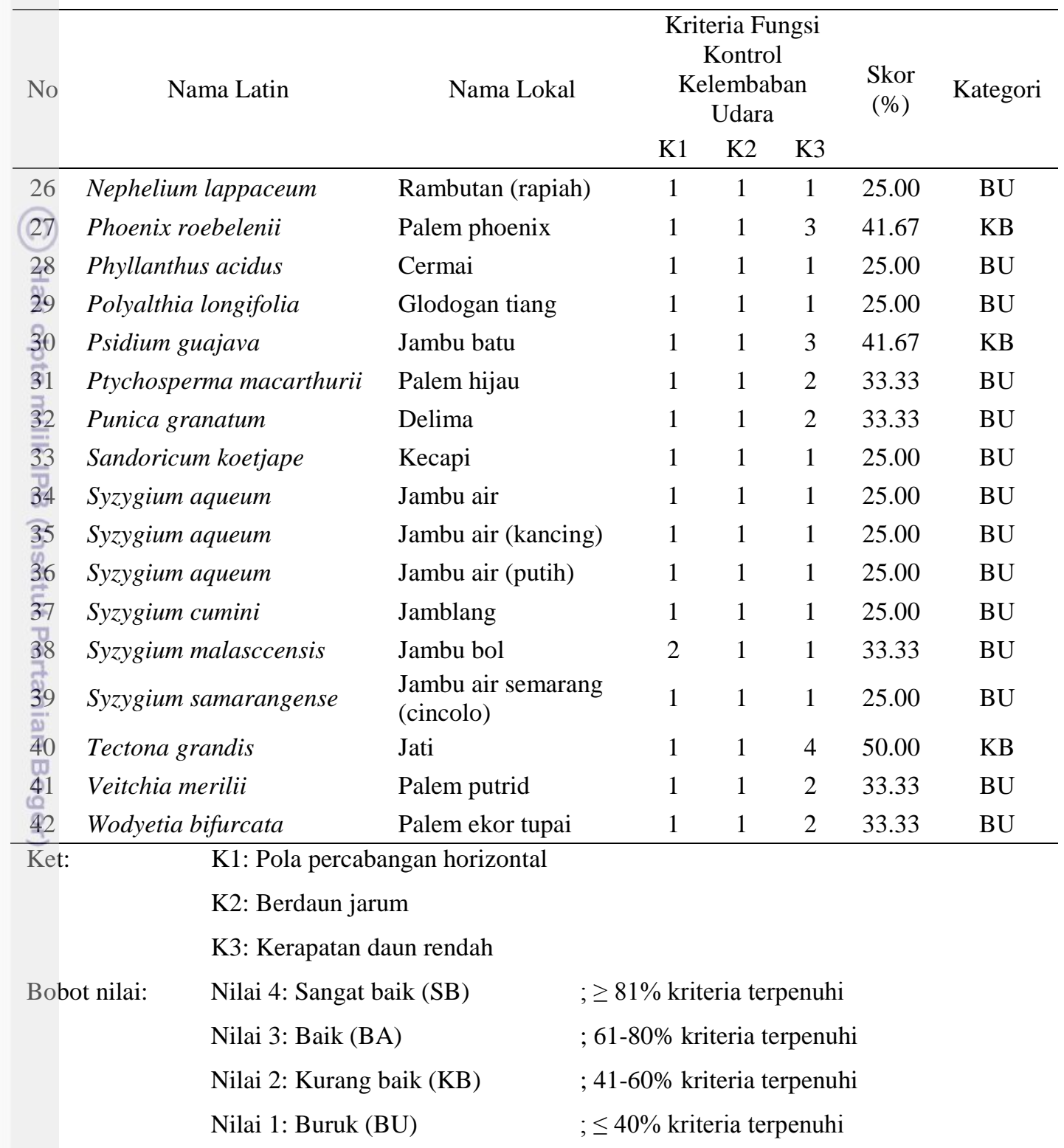

Terdapat enam jenis pohon yang tergolong kategori kurang baik, yaitu Averrhoa carambola (belimbing), Feronia lucida (kawista batu), Morinda citrifolia (mengkudu), Phoenix roebelenii (palem phoenix), Psidium guajava (jambu batu), dan Tectona grandis (jati). Kategori ini memiliki presentase sebesar 15.18\% dari total individu pohon dan $14.29 \%$ dari total jenis pohon. Pada kategori buruk, diperoleh presentase sebesar $84.82 \%$ dari total individu pohon dan 85.71\% dari total jenis pohon. 
Kawasan Perkampungan Budaya Betawi Setu Babakan berlokasi di atas area dataran rendah, sehingga jenis-jenis pohon yang terdapat di dalamnya merupakan jenis yang biasa tumbuh pada kondisi topografi serupa. Pada pemilihan jenis tanaman untuk pekarangan, warga lebih memilih jenis-jenis pohon yang sesuai dengan karakter budaya baik untuk kepentingan secara individu maupun untuk keselarasan di dalam kawasan rekreasi agro itu sendiri. Di samping itu, jenis-jenis pohon seperti cemara kurang cocok dan terlihat kontras apabila đitanam secara dominan di dalam kawasan.

\subsubsection{Peredam Kebisingan}

Berbeda dengan kawasan lingkar setu, area pekarangan memiliki tingkat kebisingan yang lebih rendah dikarenakan minimnya jumlah kendaraan yang melintas serta aktivitas masyarakat yang tidak terlalu signifikan. Perumahan bukan menjadi tempat rekreasi utama bagi pengunjung. Meski demikian, keberadaan pohon di dalam pekarangan juga penting untuk meredam kebisingan yang timbul dari sumber tertentu. Evaluasi terhadap fungsi ekologis peredam kebisingan dapat dilihat pada Tabel 19.

$\stackrel{6}{\circ}$

Tabel 19. Kriteria Penilaian Aspek Fungsi Peredam Kebisingan (Pekarangan)

\begin{tabular}{|c|c|c|c|c|c|c|c|}
\hline \multirow[t]{2}{*}{ No } & \multirow[t]{2}{*}{ Nama Latin } & \multirow[t]{2}{*}{ Nama Lokal } & \multicolumn{3}{|c|}{$\begin{array}{c}\text { Kriteria Fungsi } \\
\text { Peredam } \\
\text { Kebisingan } \\
\end{array}$} & \multirow[t]{2}{*}{$\begin{array}{c}\text { Skor } \\
(\%)\end{array}$} & \multirow[t]{2}{*}{ Kategori } \\
\hline & & & K1 & $\mathrm{K} 2$ & K3 & & \\
\hline 1 & Annona squamosa & Srikaya & 2 & 2 & 3 & 58.33 & $\mathrm{~KB}$ \\
\hline 2 & Areca catechu & Pinang & 2 & 1 & 2 & 41.67 & KB \\
\hline 3 & Artocarpus heterophyllus & Nangka & 2 & 3 & 2 & 58.33 & $\mathrm{~KB}$ \\
\hline 04 & Averrhoa carambola & Belimbing & 2 & 1 & 4 & 58.33 & $\mathrm{~KB}$ \\
\hline & Cananga odorata & Kenanga & 3 & 2 & 3 & 66.67 & BA \\
\hline & Citrus maxima & Jeruk bali & 3 & 3 & 3 & 75.00 & $\mathrm{BA}$ \\
\hline & Coryota mitis & Palem ekor ikan & 3 & 1 & 3 & 58.33 & KB \\
\hline & Crateva religiosa & Sawo duren & 3 & 2 & 3 & 66.67 & BA \\
\hline & Dimocarpus longan & Lengkeng & 4 & 3 & 3 & 83.33 & SB \\
\hline 10 & Durio zibethinus & Durian montong & 2 & 2 & 2 & 50.00 & KB \\
\hline 11 & Feronia lucida & Kawista batu & 1 & 2 & 1 & 33.33 & $\mathrm{BU}$ \\
\hline 12 & Ficus benjamina & Beringin & 4 & 4 & 4 & 100.00 & SB \\
\hline 13 & Flacourtia rukam & Rukem & 3 & 3 & 4 & 83.33 & $\mathrm{BA}$ \\
\hline 14 & Gnetum gnemon & Melinjo & 4 & 2 & 3 & 75.00 & $\mathrm{BA}$ \\
\hline
\end{tabular}


Tabel 19. Kriteria Penilaian Aspek Fungsi Peredam Kebisingan (Pekarangan) (Lanjutan)

\begin{tabular}{|c|c|c|c|c|c|c|c|}
\hline \multirow[t]{2}{*}{ No } & \multirow[t]{2}{*}{ Nama Latin } & \multirow[t]{2}{*}{ Nama Lokal } & \multicolumn{3}{|c|}{$\begin{array}{l}\text { Peredam } \\
\text { Kebisingan }\end{array}$} & \multirow[t]{2}{*}{$\begin{array}{l}\text { Skor } \\
(\%)\end{array}$} & \multirow[t]{2}{*}{ Kategori } \\
\hline & & & K1 & K2 & K3 & & \\
\hline 15 & Lansium domesticum & Duku condet & 4 & 3 & 4 & 91.67 & SB \\
\hline 16 & Mangifera indica & Mangga (apel) & 4 & 1 & 2 & 58.33 & $\mathrm{~KB}$ \\
\hline (17) & Mangifera indica & Mangga (arum manis) & 4 & 3 & 3 & 83.33 & SB \\
\hline \multirow{3}{*}{$\begin{array}{l}18 \\
719 \\
70 \\
010\end{array}$} & Mangifera indica & Mangga (okyong) & 4 & 1 & 2 & 58.33 & KB \\
\hline & Manilkara zapota & Sawo manila (betawi) & 4 & 3 & 4 & 91.67 & SB \\
\hline & Manilkara zapota & Sawo manila (kulon) & 4 & 3 & 4 & 91.67 & SB \\
\hline \multirow{3}{*}{$\begin{array}{l}21 \\
322 \\
22 \\
23\end{array}$} & Morinda citrifolia & Mengkudu & 3 & 1 & 2 & 50.00 & KB \\
\hline & Nephelium lappaceum & Rambutan (aceh) & 4 & 3 & 4 & 91.67 & SB \\
\hline & Nephelium lappaceum & Rambutan (binjai) & 4 & 3 & 4 & 91.67 & SB \\
\hline 24 & Nephelium lappaceum & Rambutan (cimacan) & 4 & 3 & 4 & 91.67 & SB \\
\hline \multirow{2}{*}{$\begin{array}{l}25 \\
26\end{array}$} & Nephelium lappaceum & Rambutan (cipelat) & 4 & 3 & 4 & 91.67 & SB \\
\hline & Nephelium lappaceum & Rambutan (rapiah) & 4 & 3 & 4 & 91.67 & SB \\
\hline \multirow{2}{*}{$\begin{array}{l}27 \\
28\end{array}$} & Phoenix roebelenii & Palem phoenix & 1 & 1 & 1 & 25.00 & BU \\
\hline & Phyllanthus acidus & Cermai & 3 & 3 & 4 & 83.33 & SB \\
\hline \multirow{2}{*}{$\begin{array}{l}29 \\
30\end{array}$} & Polyalthia longifolia & Glodogan tiang & 4 & 1 & 3 & 66.67 & BA \\
\hline & Psidium guajava & Jambu batu & 2 & 2 & 2 & 50.00 & $\mathrm{~KB}$ \\
\hline \multirow{2}{*}{$\begin{array}{l}\sqrt{31} \\
62 \\
32\end{array}$} & Ptychosperma macarthurii & Palem hijau & 2 & 2 & 2 & 50.00 & $\mathrm{~KB}$ \\
\hline & Punica granatum & Delima & 2 & 1 & 3 & 50.00 & $\mathrm{~KB}$ \\
\hline 33 & Sandoricum koetjape & Kecapi & 4 & 3 & 4 & 91.67 & SB \\
\hline \multirow{2}{*}{$\begin{array}{l}34 \\
35\end{array}$} & Syzygium aqueum & Jambu air & 3 & 3 & 4 & 83.33 & SB \\
\hline & Syzygium aqueum & Jambu air (kancing) & 3 & 2 & 2 & 58.33 & KB \\
\hline 36 & Syzygium aqueum & Jambu air (putih) & 3 & 2 & 2 & 58.33 & KB \\
\hline \multirow{2}{*}{$\begin{array}{l}37 \\
38\end{array}$} & Syzygium cumini & Jamblang & 3 & 3 & 4 & 83.33 & SB \\
\hline & Syzygium malasccensis & Jambu bol & 4 & 3 & 3 & 83.33 & SB \\
\hline 39 & Syzygium samarangense & $\begin{array}{l}\text { Jambu air semarang } \\
\text { (cincolo) }\end{array}$ & 3 & 3 & 4 & 83.33 & SB \\
\hline 40 & Tectona grandis & Jati & 1 & 3 & 1 & 41.67 & KB \\
\hline \multirow{2}{*}{$\begin{array}{l}41 \\
42 \\
\end{array}$} & Veitchia merilii & Palem putri & 2 & 1 & 1 & 33.33 & BU \\
\hline & Wodyetia bifurcata & Palem ekor tupai & 2 & 2 & 2 & 50.00 & KB \\
\hline \multicolumn{8}{|c|}{ 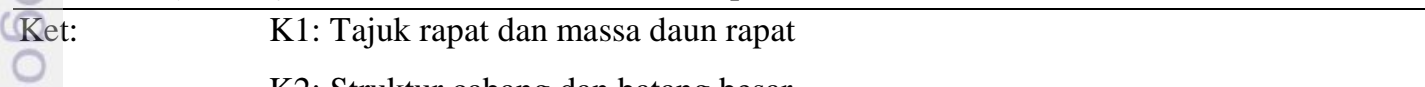 } \\
\hline \multicolumn{8}{|c|}{ K2: Struktur cabang dan batang besar } \\
\hline \multicolumn{8}{|c|}{ K3: Daun rindang dan ringan } \\
\hline Bobot nilai: & \multicolumn{2}{|c|}{ Nilai 4: Sangat baik (SB) } & \multicolumn{3}{|c|}{ kriteria terpenuhi } & & \\
\hline $\bar{\Omega}$ & Nilai 3: Baik (BA & ; 61-80 & krit & 政 & enuhi & & \\
\hline & Nilai 2: Kurang b & $\mathrm{ik}(\mathrm{KB})$ & o kri & Id & enuhi & & \\
\hline$\underline{\bar{c}}$ & Nilai 1: Buruk (B & $; \leq 40^{\circ}$ & krite & tes & nuhi & & \\
\hline
\end{tabular}


Berdasarkan penilaian yang dilakukan, diperoleh jenis-jenis pohon pada kategori sangat baik, yaitu Dimocarpus longan (lengkeng), Ficus benjamina (beringin), Lansium domesticum (duku condet), Mangifera indica (mangga (arum manis)), Manilkara zapota (sawo manila (betawi)), Manilkara zapota (sawo manila (kulon)), Nephelium lappaceum (rambutan (aceh)), Nephelium lappaceum (rambutan (binjai)), Nephelium lappaceum (rambutan (cimacan)), Nephelium lappaceum (rambutan (cipelat)), Nephelium lappaceum (rambutan (rapiah)), 긋llanthus acidus (cermai), Sandoricum koetjape (kecapi), Syzygium aqueum (jambu air), Syzygium cumini (jamblang), Syzygium malasccense (jambu bol), dan Syzygium samarangense (jambu air semarang (cincolo). Kategori ini memiliki presentase sebesar $38.39 \%$ dari total individu pohon dan $40.48 \%$ dari total jenis pohon.

Selain itu, jenis-jenis pohon yang termasuk dalam kategori baik, yaitu Eananga odorata (kenanga), Citrus maxima (jeruk bali), Crateva religiosa (sawo duren), Flacourtia rukam (rukem), Gnetum gnemon (melinjo), dan Polyalthia 吕ngifolia (glodogan tiang). Presentase untuk kategori ini adalah sebesar 14.29\% dari total individu pohon dan $14.29 \%$ dari total jenis pohon. Kategori kurang baik têrdiri dari jenis-jenis pohon seperti Annona squamosa (srikaya), Areca catechu (pinang), Artocarpus heterophyllus (nangka), Averrhoa carambola (belimbing), Coryota mitis (palem ekor ikan), Durio zibethinus (durian montong), Mangifera indica (mangga (apel)), Mangifera indica (mangga (okyong)), Morinda citrifolia (mengkudu), Psidium guajava (jambu batu), Ptychosperma macarthurii (palem hijau), Punica granatum (delima), Syzygium aqueum (jambu air (kancing)), Syzygium aqueum (jambu air (putih)), Tectona grandis (jati) dan Wodyetia bifurcata (palem ekor tupai), dengan presentase sebesar $41.07 \%$ dari total individu (pohon dan 38.10\% dari total jenis pohon. Jenis-jenis pohon pada kategori buruk, yaitu Feronia lucida (kawista batu), Phoenix roebelenii (palem phoenix), dan Veitchia merilii (palem putri) dengan presentase sebesar 6.25\% dari total individu pohon dan 7.14\% dari total jenis pohon. Jadi, dapat dikatakan bahwa jenis pohon yang paling mendominasi adalah pohon yang termasuk dalam kategori sangat baik. Adapun pada kategori kurang baik, rata-rata jenis pohon tergolong tanaman bervarietas unggul serta pohon dari jenis palem-paleman. 


\subsubsection{Penahan Angin}

Kecepatan angin yang melebihi standar baku mutu serta hembusannya yang dapat membawa serta debu dari lingkungan sekitar dapat mengganggu kenyamanan pemilik rumah. Pohon dengan jenis tertentu berfungsi membentuk sebuah penghalang yang dapat meminimalisasi masuknya angin ke dalam rumah melalui pola penanaman. Hasil evaluasi terhadap fungsi ekologis pohon penahan angin dapat dilihat pada Tabel 20.

\begin{tabular}{|c|c|c|c|c|c|c|c|}
\hline \multirow{2}{*}{ 竞o } & \multirow[t]{2}{*}{ Nama Latin } & \multirow[t]{2}{*}{ Nama Lokal } & \multicolumn{3}{|c|}{$\begin{array}{l}\text { Kriteria Fungsi } \\
\text { Penahan Angin }\end{array}$} & \multirow[t]{2}{*}{$\begin{array}{l}\text { Skor } \\
(\%)\end{array}$} & \multirow[t]{2}{*}{ Kategori } \\
\hline & & & $\mathrm{K} 1$ & $\mathrm{~K} 2$ & K3 & & \\
\hline & Annona squamosa & Srikaya & 2 & 2 & 2 & 50.00 & KB \\
\hline & Areca catechu & Pinang & 1 & 2 & 2 & 41.67 & $\mathrm{~KB}$ \\
\hline$=$ & Artocarpus heterophyllus & Nangka & 2 & 2 & 3 & 58.33 & KB \\
\hline 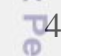 & Averrhoa carambola & Belimbing & 3 & 1 & 1 & 41.67 & KB \\
\hline 5 & Cananga odorata & Kenanga & 3 & 2 & 2 & 58.33 & KB \\
\hline E 6 & Citrus maxima & Jeruk bali & 3 & 3 & 3 & 75.00 & BA \\
\hline & Coryota mitis & Palem ekor ikan & 2 & 1 & 1 & 33.33 & BU \\
\hline 8 & Crateva religiosa & Sawo duren & 4 & 2 & 3 & 75.00 & BA \\
\hline 9 & Dimocarpus longan & Lengkeng & 4 & 4 & 3 & 91.67 & SB \\
\hline 10 & Durio zibethinus & Durian montong & 2 & 3 & 2 & 58.33 & KB \\
\hline 11 & Feronia lucida & Kawista batu & 1 & 2 & 1 & 33.33 & $\mathrm{BU}$ \\
\hline 12 & Ficus benjamina & Beringin & 4 & 4 & 4 & 100.00 & SB \\
\hline 13 & Flacourtia rukam & Rukem & 3 & 3 & 4 & 83.33 & SB \\
\hline 14 & Gnetum gnemon & Melinjo & 4 & 2 & 4 & 83.33 & SB \\
\hline 15 & Lansium domesticum & Duku condet & 3 & 4 & 3 & 83.33 & SB \\
\hline 16 & Mangifera indica & Mangga (apel) & 3 & 2 & 1 & 50.00 & $\mathrm{~KB}$ \\
\hline 17 & Mangifera indica & $\begin{array}{l}\text { Mangga (arum } \\
\text { manis) }\end{array}$ & 4 & 3 & 3 & 83.33 & SB \\
\hline & Mangifera indica & Mangga (okyong) & 3 & 2 & 1 & 50.00 & $\mathrm{~KB}$ \\
\hline & Manilkara zapota & $\begin{array}{l}\text { Sawo manila } \\
\text { (betawi) }\end{array}$ & 4 & 4 & 3 & 91.67 & SB \\
\hline & Manilkara zapota & Sawo manila (kulon) & 4 & 4 & 3 & 91.67 & SB \\
\hline 21 & Morinda citrifolia & Mengkudu & 2 & 2 & 2 & 50.00 & KB \\
\hline 22 & Nephelium lappaceum & Rambutan (aceh) & 4 & 3 & 3 & 83.33 & SB \\
\hline & Nephelium lappaceum & Rambutan (binjai) & 4 & 3 & 3 & 83.33 & SB \\
\hline 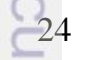 & Nephelium lappaceum & Rambutan (cimacan) & 4 & 3 & 3 & 83.33 & SB \\
\hline 25 & Nephelium lappaceum & Rambutan (cipelat) & 4 & 3 & 3 & 83.33 & SB \\
\hline 26 & Nephelium lappaceum & Rambutan (rapiah) & 4 & 3 & 3 & 83.33 & SB \\
\hline 27 & Phoenix roebelenii & Palem phoenix & 1 & 1 & 1 & 25.00 & BU \\
\hline 28 & Phyllanthus acidus & Cermai & 3 & 4 & 3 & 83.33 & SB \\
\hline
\end{tabular}


Tabel 20. Kriteria Penilaian Aspek Fungsi Penahan Angin (Pekarangan) (Lanjutan)

\begin{tabular}{|c|c|c|c|c|c|c|c|}
\hline \multirow[t]{2}{*}{ No } & \multirow[t]{2}{*}{ Nama Latin } & \multirow[t]{2}{*}{ Nama Lokal } & \multicolumn{3}{|c|}{$\begin{array}{l}\text { Kriteria Fungsi } \\
\text { Penahan Angin }\end{array}$} & \multirow{2}{*}{$\begin{array}{l}\text { Skor } \\
(\%)\end{array}$} & \multirow[t]{2}{*}{ Kategori } \\
\hline & & & K1 & $\mathrm{K} 2$ & K3 & & \\
\hline 29 & Polyalthia longifolia & Glodogan tiang & 4 & 1 & 4 & 75.00 & BA \\
\hline 30 & Psidium guajava & Jambu batu & 2 & 3 & 2 & 58.33 & KB \\
\hline 31 & $\begin{array}{l}\text { Ptychosperma } \\
\text { macarthurii }\end{array}$ & Palem hijau & 2 & 3 & 2 & 58.33 & KB \\
\hline \multirow{2}{*}{$\frac{32}{33}$} & Punica granatum & Delima & 2 & 2 & 2 & 50.00 & KB \\
\hline & Sandoricum koetjape & Kecapi & 4 & 3 & 3 & 83.33 & SB \\
\hline \multirow{2}{*}{$\begin{array}{l}34 \\
34 \\
35\end{array}$} & Syzygium aqueum & Jambu air & 4 & 4 & 3 & 91.67 & SB \\
\hline & Syzygium aqueum & Jambu air (kancing) & 2 & 2 & 1 & 41.67 & $\mathrm{~KB}$ \\
\hline 36 & Syzygium aqueum & Jambu air (putih) & 2 & 2 & 1 & 41.67 & KB \\
\hline 37 & Syzygium cumini & Jamblang & 3 & 4 & 3 & 83.33 & SB \\
\hline 38 & Syzygium malasccensis & Jambu bol & 4 & 3 & 3 & 83.33 & SB \\
\hline (39 & Syzygium samarangense & $\begin{array}{l}\text { Jambu air semarang } \\
\text { (cincolo) }\end{array}$ & 4 & 3 & 3 & 83.33 & SB \\
\hline 40 & Tectona grandis & Jati & 1 & 2 & 4 & 58.33 & KB \\
\hline 41 & Veitchia merilii & Palem putri & 2 & 1 & 3 & 50.00 & KB \\
\hline 42 & Wodyetia bifurcata & Palem ekor tupai & 2 & 3 & 2 & 58.33 & KB \\
\hline Ket: & K1: Tajuk m & f dan rindang & & & & & \\
\hline $\begin{array}{l}5 \\
0 \\
\circ \\
\wp\end{array}$ & $\begin{array}{l}\text { K2: Dahan yai } \\
\text { K3: Vegetasi t }\end{array}$ & $\begin{array}{l}\text { kuat tapi cukup lentu } \\
\text { lggi }\end{array}$ & & & & & \\
\hline Bobo & Nilai 4: Sanga & baik (SB) & $\% \mathrm{k}$ & teria & erpen & & \\
\hline & Nilai 3: Baik ( & & $80 \%$ & riteri & terpe & & \\
\hline & Nilai 2: Kuran & baik (KB) & $60 \%$ & riteri & terpe & & \\
\hline & Nilai 1: Buruk & $\mathrm{BU})$ & $0 \% \mathrm{k}$ & iteria & erper & & \\
\hline
\end{tabular}

Berdasarkan penilaian yang dilakukan, maka diperoleh jenis-jenis pohon yang termasuk kategori sangat baik, yaitu Dimocarpus longan (lengkeng), Ficus benjamina (beringin), Flacourtia rukam (rukem), Gnetum genmon (melinjo), Eansium domesticum (duku condet), Mangifera indica (mangga (arum manis)), Manilkara zapota (sawo manila (betawi)), Manilkara zapota (sawo manila (kulon)), Nephelium lappaceum (rambutan (aceh)), Nephelium lappaceum (rambutan (binjai)), Nephelium lappaceum (rambutan (cimacan)), Nephelium lappaceum (rambutan (cipelat)), Nephelium lappaceum (rambutan (rapiah)), Phyllanthus acidus (cermai), Sandoricum koetjape (kecapi), Syzygium aqueum (jambu air), Syzygium cumini (jamblang), Syzygium malasccense (jambu bol), dan Syzygium samarangense (jambu air semarang (cincolo)). Kategori ini memiliki 
presentase sebesar $45.54 \%$ dari total individu pohon dan $45.24 \%$ dari total jenis pohon.

Jenis-jenis pohon yang termasuk ke dalam kategori baik, yaitu Citrus maxima (jeruk bali), Crateva religiosa (sawo duren), dan Polyalthia longifolia (glodogan tiang) dengan presentase sebesar 5.36\% dari total individu pohon dan 7.14\% dari total jenis pohon. Pada kategori kurang baik, terdapat Annona squamosa (srikaya), Areca catechu (pinang), Artocarpus heterophyllus (nangka), $\overline{\bar{A}}$ verrhoa carambola (belimbing), Cananga odorata (kenanga), Durio zibethinus (durian), Mangifera indica (mangga (apel)), Mangifera indica (mangga (okyong)), Morinda citrifolia (mengkudu), Psidium guajava (jambu batu), Ptychosperma 产acarthurii (palem hijau), Punica granatum (delima), Syzygium aqueum (jambu air (kancing)), Syzygium aqueum (jambu air (putih)), Tectona grandis (jati), Veitchia merilii (palem putri) dan Wodyetia bifurcata (palem ekor tupai). Presentase yang diperoleh sebesar $45.54 \%$ dari total individu pohon dan $40.48 \%$ dari total jenis pohon. Adapun pada kategori buruk, jenis-jenis pohon terdiri dari Goryota mitis (palem ekor ikan), Feronia lucida (kawista batu), dan Phoenix roebelenii (palem phoenix) dengan presentase sebesar 3.57\% dari total individu pohon dan $7.14 \%$ dari total jenis pohon.

\subsubsection{Kehadiran Satwa (Burung)}

Mayoritas pemilik pekarangan rumah menggunakan jenis-jenis pohon produksi sebagai elemen vegetasi yang ditanam pada halaman rumah mereka. Selain memiliki manfaat produksi, pohon-pohon tersebut juga mampu menghadirkan satwa burung oleh karena terdapatnya biji, nektar, serta buah yang dihasilkan itu sendiri. Pada beberapa pohon juga ditemukan ulat sebagai pakan (bagi burung pemakan hama tersebut. Kehadiran burung itu sendiri selain mengindikasikan suatu udara yang bersih juga mampu memberikan suasana asri bagi pemilik rumah oleh karena kicauan merdu yang dihasilkan satwa liar ini. Evaluasi terhadap fungsi ekologis pohon untuk dapat menghadirkan satwa burung dapat dilihat pada Tabel 21. 
Tabel 21. Kriteria Penilaian Aspek Fungsi Menghadirkan Satwa (Burung) (Pekarangan)

\begin{tabular}{|c|c|c|c|c|c|c|c|}
\hline \multirow[t]{2}{*}{ No } & \multirow[t]{2}{*}{ Nama Latin } & \multirow[t]{2}{*}{ Nama Lokal } & \multicolumn{3}{|c|}{$\begin{array}{l}\text { Kriteria Fungsi } \\
\text { Menghadirkan } \\
\text { Satwa (Burung) }\end{array}$} & \multirow[t]{2}{*}{$\begin{array}{l}\text { Skor } \\
(\%)\end{array}$} & \multirow[t]{2}{*}{ Kategori } \\
\hline & & & $\mathrm{K} 1$ & $\mathrm{~K} 2$ & K3 & & \\
\hline 1 & Annona squamosa & Srikaya & 4 & 4 & 2 & 83.33 & SB \\
\hline $2^{2}$ & Areca catechu & Pinang & 4 & 4 & 3 & 91.67 & SB \\
\hline 3 & Artocarpus heterophyllus & Nangka & 4 & 4 & 2 & 83.33 & SB \\
\hline$\frac{T}{20} 4$ & Averrhoa carambola & Belimbing & 4 & 4 & 4 & 100.00 & SB \\
\hline 5 & Cananga odorata & Kenanga & 4 & 1 & 3 & 66.67 & BA \\
\hline 6 & Citrus maxima & Jeruk bali & 4 & 4 & 3 & 91.67 & SB \\
\hline 37 & Coryota mitis & Palem ekor ikan & 4 & 1 & 4 & 75.00 & BA \\
\hline 8 & Crateva religiosa & Sawo duren & 4 & 4 & 2 & 83.33 & SB \\
\hline$\overline{7}$ & Dimocarpus longan & Lengkeng & 4 & 4 & 3 & 91.67 & SB \\
\hline 10 & Durio zibethinus & Durian montong & 4 & 4 & 2 & 83.33 & SB \\
\hline 11 & Feronia lucida & Kawista batu & 4 & 4 & 3 & 91.67 & SB \\
\hline 12 & Ficus benjamina & Beringin & 4 & 1 & 4 & 75.00 & BA \\
\hline 13 & Flacourtia rukam & Rukem & 4 & 4 & 3 & 91.67 & SB \\
\hline 74 & Gnetum gnemon & Melinjo & 4 & 4 & 2 & 83.33 & SB \\
\hline 35 & Lansium domesticum & Duku condet & 4 & 4 & 3 & 91.67 & SB \\
\hline 16 & Mangifera indica & Mangga (apel) & 4 & 4 & 2 & 83.33 & SB \\
\hline 97 & Mangifera indica & $\begin{array}{l}\text { Mangga (arum } \\
\text { manis) }\end{array}$ & 4 & 4 & 3 & 91.67 & SB \\
\hline 78 & Mangifera indica & Mangga (okyong) & 4 & 4 & 2 & 83.33 & SB \\
\hline 19 & Manilkara zapota & $\begin{array}{l}\text { Sawo manila } \\
\text { (betawi) }\end{array}$ & 4 & 4 & 3 & 91.67 & $\mathrm{SB}$ \\
\hline 20 & Manilkara zapota & Sawo manila (kulon) & 4 & 4 & 3 & 91.67 & SB \\
\hline 21 & Morinda citrifolia & Mengkudu & 1 & 4 & 1 & 50.00 & KB \\
\hline 22 & Nephelium lappaceum & Rambutan (aceh) & 4 & 4 & 3 & 91.67 & SB \\
\hline $\begin{array}{l}\text { SB } \\
23\end{array}$ & Nephelium lappaceum & Rambutan (binjai) & 4 & 4 & 3 & 91.67 & SB \\
\hline 24 & Nephelium lappaceum & Rambutan (cimacan) & 4 & 4 & 3 & 91.67 & SB \\
\hline 25 & Nephelium lappaceum & Rambutan (cipelat) & 4 & 4 & 3 & 91.67 & SB \\
\hline 6 & Nephelium lappaceum & Rambutan (rapiah) & 4 & 4 & 3 & 91.67 & SB \\
\hline & Phoenix roebelenii & Palem phoenix & 1 & 1 & 3 & 41.67 & KB \\
\hline & Phyllanthus acidus & Cermai & 4 & 4 & 4 & 100.00 & SB \\
\hline & Polyalthia longifolia & Glodogan tiang & 4 & 4 & 2 & 83.33 & SB \\
\hline & Psidium guajava & Jambu batu & 4 & 4 & 2 & 83.33 & SB \\
\hline & $\begin{array}{l}\text { Ptychosperma } \\
\text { macarthurii }\end{array}$ & Palem hijau & 1 & 1 & 3 & 41.67 & KB \\
\hline & Punica granatum & Delima & 4 & 4 & 3 & 91.67 & SB \\
\hline 33 & Sandoricum koetjape & Kecapi & 4 & 4 & 3 & 91.67 & SB \\
\hline 34 & Syzygium aqueum & Jambu air & 4 & 4 & 3 & 91.67 & SB \\
\hline 35 & Syzygium aqueum & Jambu air (kancing) & 4 & 4 & 3 & 91.67 & SB \\
\hline 36 & Syzygium aqueum & Jambu air (putih) & 4 & 4 & 3 & 91.67 & SB \\
\hline
\end{tabular}


Tabel 21. Kriteria Penilaian Aspek Fungsi Menghadirkan Satwa (Burung) (Pekarangan) (Lanjutan)

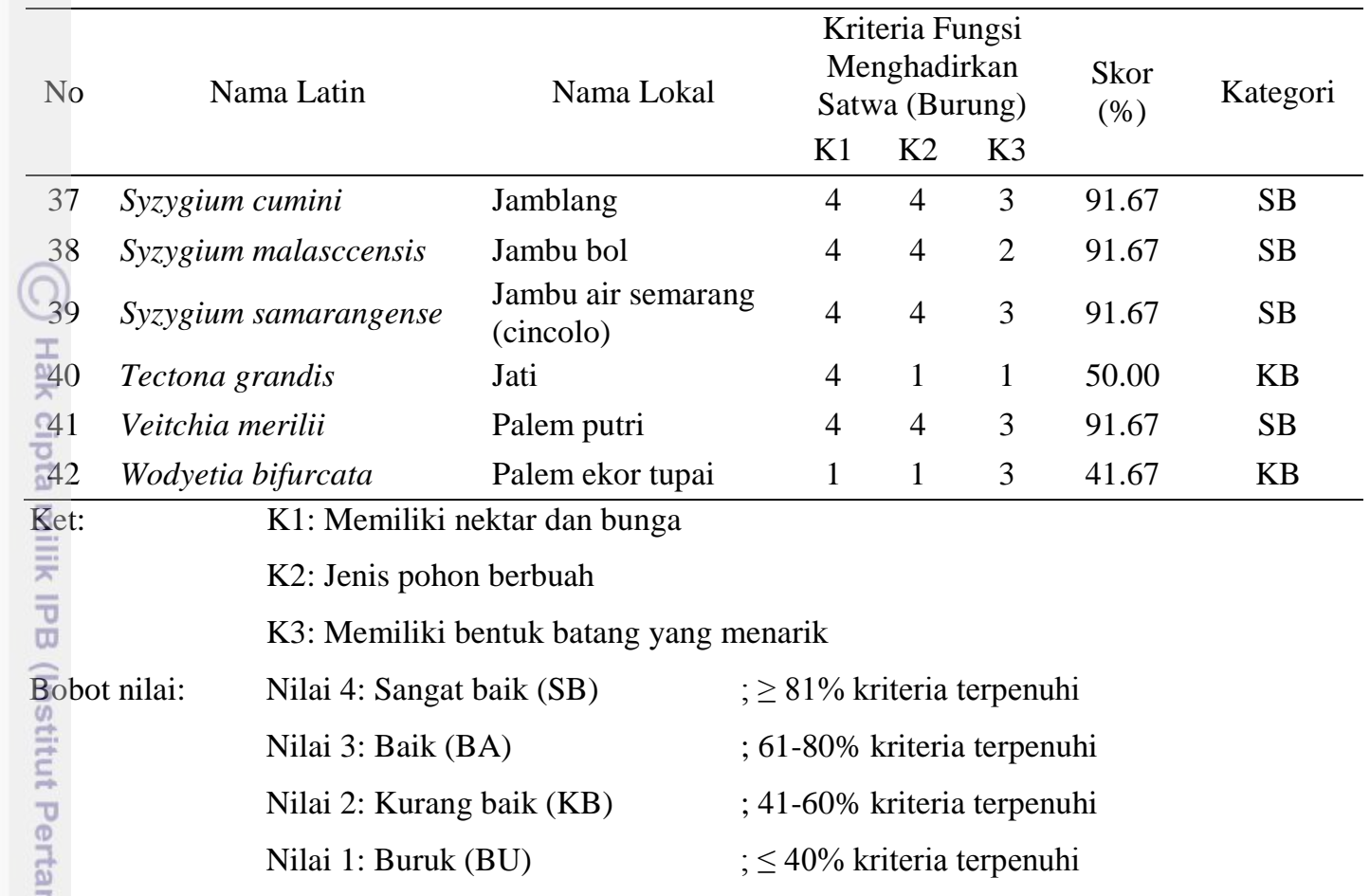

Berdasarkan hasil penilaian di atas, jenis-jenis pohon yang termasuk kategori sangat baik, yaitu Annona squamosa (srikaya), Areca catechu (pinang), Artocarpus heterophyllus (nangka), Averrhoa carambola (belimbing), Citrus maxima (jeruk bali), Crateva religiosa (sawo duren), Dimocarpus longan (lengkeng), Durio zibethinus (durian montong), Feronia lucida (kawista batu), Flacourtia rukam (rukem), Gnetum gnemon (melinjo), Lansium domesticum (duku condet), Mangifera indica (mangga (apel)), Mangifera indica (mangga (arum manis)), Mangifera indica (mangga (okyong)), Manilkara zapota (sawo manila (betawi)), Manilkara zapota (sawo manila (kulon)), Nephelium lappaceum (rambutan (aceh)), Nephelium lappaceum (rambutan (binjai)), Nephelium tappaceum (rambutan (cimacan)), )), Nephelium lappaceum (rambutan (cipelat)), Nephelium lappaceum (rambutan (rapiah)), Phyllanthus acidus (cermai), Polyalthia longifolia (glodogan tiang), Psidium guajava (jambu batu), Punica granatum (delima), Sandoricum koetjape (kecapi), Syzygium aqueum (jambu air), Syzygium aqueum (jambu air (kancing)), Syzygium aqueum (jambu air (putih)), Syzygium cumini (jamblang), Syzygium malasccensis (jambu bol), Syzygium 
samarangense (jambu air semarang (cincolo)), dan Veitchia merilii (palem putri). Pada kategori ini, diperolehlah presentase sebesar 83.93\% dari total individu pohon dan $80.95 \%$ dari total jenis pohon. Nilai ini menunjukkan bahwa jenis-jenis pohon yang ramah terhadap kehadiran burung sangat mendominasi jenis penanaman yang berada di dalam pekarangan. Rata-rata pohon merupakan jenis tanaman penghasil buah yang disukai oleh satwa burung pada jenis tertentu. Adanya buah juga mampu mendatangkan ulat yang dapat dijadikan sebagai pakan bagai burung pemakan ulat. Selain itu, adapun beberapa tanaman yang juga mampu m̊̊nenghasilkan nektar dan biji.

Jenis-jenis pohon yang termasuk kategori baik, yaitu Cananga odorata (kenanga), Coryota mitis (palem ekor ikan), dan Ficus benjamina (beringin) dengan presentase sebesar $4.46 \%$ dari total individu pohon dan $7.14 \%$ dari total jenis pohon. Pada kategori kurang baik, terdapat Morinda citrifolia (mengkudu), P्Phoenix roebelenii (palem phoenix), Ptychosperma macarthurii (palem hijau), Fectona grandis (jati), dan Wodyetia bifurcata (palem ekor tupai) dengan presentase sebesar $11.61 \%$ dari total individu pohon dan $11.90 \%$ dari total jenis pohon. 


\section{BAB VI \\ REKOMENDASI}

\subsection{Jenis-Jenis Pohon Langka pada Lanskap Area Rekreasi Setu Babakan}

Keberadaan jenis-jenis pohon langka yang berada pada tapak telah menjadi potensi tersendiri sebagai salah satu objek di dalam mengembangkan kawasan rekreasi yang senantiasa mengedepankan nilai konservasi dan edukasi. Akan tetapi, unsur tersebut masih belum terlihat maksimal oleh karena minimnya fasilitas-fasilitas penunjang bagi pengunjung yang ingin memperoleh pengetahuan lebih mengenai Perkampungan Budaya Betawi Setu Babakan. Berdasarkan pengamatan yang telah dilakukan, maka diperoleh beberapa gagasan yang dapat dïberikan sebagai rekomendasi untuk dapat mengembangkan kawasan rekreasi berwawasan konservasi dan edukasi ini ke arah yang lebih baik, yaitu dengan pemberian papan nama pada masing-masing individu pohon, pembuatan papan informasi, peningkatan kerjasama dengan pihak-pihak terkait, serta pemberian pelatihan konservasi.

Pemberian papan nama pada masing-masing individu pohon sangatlah Benting, terutama untuk memfasilitasi berbagai kegiatan yang berkaitan dengan kepentingan studi. Tidak hanya itu, upaya ini juga mampu mengedukasi masyarakat untuk mengenal jenis-jenis pohon yang dapat dijumpai pada area rekreasi Setu Babakan, termasuk jenis-jenis yang tergolong langka. Selama ini, hanya sedikit penduduk lokal yang tahu akan jenis-jenis pohon yang tersebar di sekitar lingkungan tempat mereka tinggal. Papan informasi juga sangat penting untuk memberikan petunjuk bagi lokasi-lokasi jenis pohon yang tergolong langka atau khas beserta deskripsinya, serta memberikan gambaran berupa pemetaan terhadap sebaran jenis-jenis pohon pada tapak. Adapun selain pemberian fasilitas informasi melalui media tertentu, adanya peningkatan kerjasama dengan pihakpihak terkait juga menjadi hal yang sangat penting sebagai salah satu bentuk upaya pelestarian menuju konsep area rekreasi konservasi dan edukasi yang lebih matang. Hal yang dapat dilakukan antara lain dengan menambah pemberian bibitbibit tanaman baru, tidak hanya pada area lingkar danau saja namun juga pekarangan-pekarangan rumah di dalam kawasan inti, pembangunan fasilitasfasilitas pendukung kegiatan penelitian dan studi, serta membentuk organisasi 
khusus di dalam ruang pengelolaan yang dapat langsung terhubung dengan instansi terkait sehingga pemantauan terhadap unsur-unsur keilmuan alam di dalam kawasan dapat lebih maksimal. Selain itu, upaya lain yang dapat dilakukan yaitu dengan memberikan pelatihan konservasi kepada pemilik pekarangan rumah yang tinggal di dalam kawasan, sehingga untuk ke depannya pemilik mampu secara langsung memaparkan keragaman jenis vegetasi maupun sejarah singkat mengenai tanaman-tanaman yang berada di Perkampungan Budaya Betawi Setu B̄abakan kepada pengunjung yang hendak melakukan wisata dan studi. Rekomendasi tersebut dapat dilihat di dalam ilustrasi pada Gambar 18.

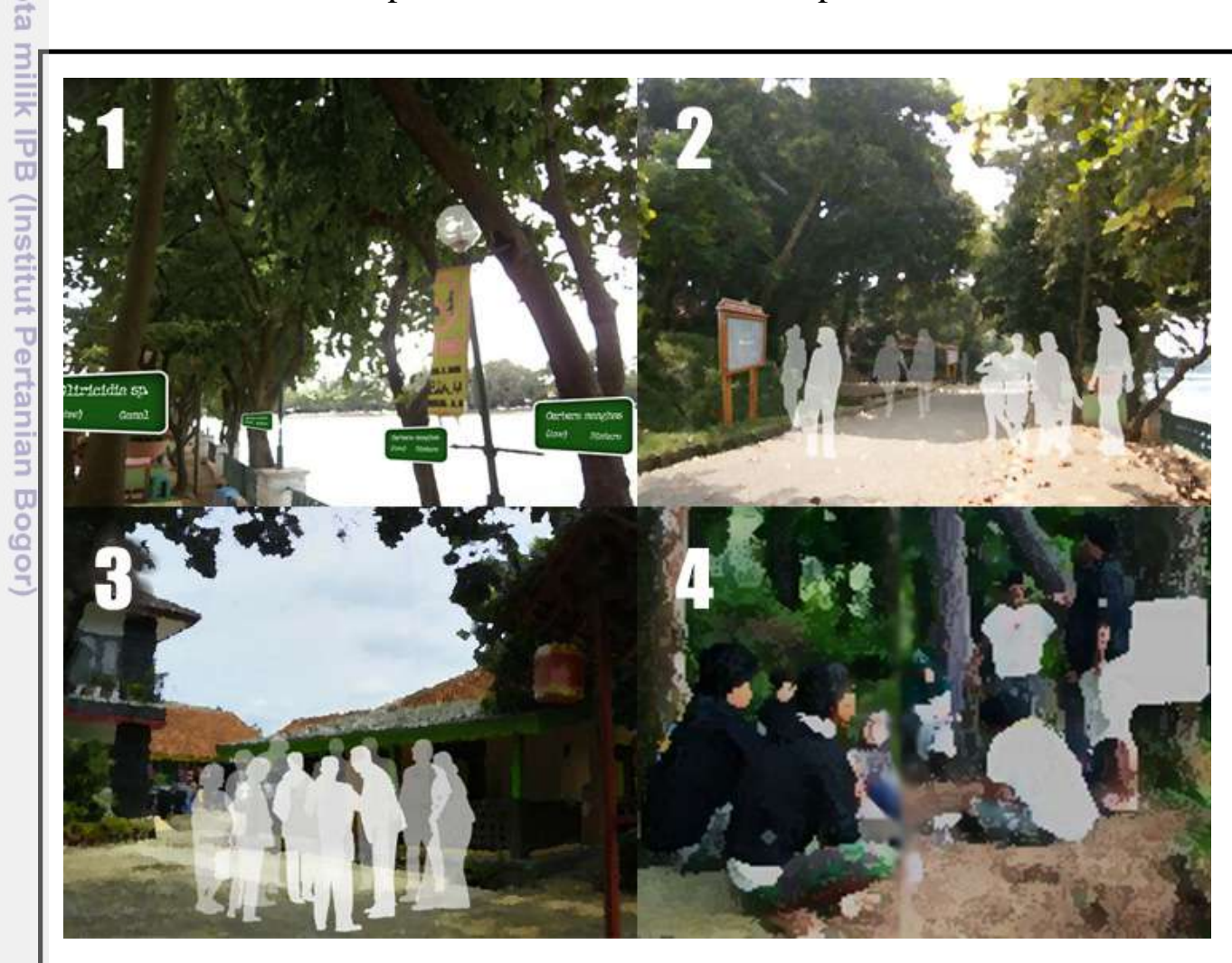

Gambar 18. Rekomendasi konservasi pohon (1) Papan nama pohon (2) Papan informasi (3) Kerjasama (4) Pelatihan Konservasi

\subsection{Keragaman Pohon}

Melalui perhitungan menggunakan metode Shannon-Wiener (Odum 1998), diperoleh sebuah nilai indeks keragaman yang menunjukkan bahwa keragaman spesies pohon pada area lingkar Setu Babakan tergolong tinggi. Rekomendasi yang dapat diberikan antara lain memberikan pengelolaan secara 
maksimal untuk menghindari kerusakan dan terjangkitnya pohon dari berbagai penyakit tertentu yang dapat menyebabkan kerusakan hingga hilangnya individu pohon. Pengelolaan tersebut dapat dilakukan berupa pemantauan secara rutin terhadap masing-masing individu pohon untuk berbagai kemungkinan penyakit dan kerusakan, menanam tanaman pengganti pada pohon yang hilang akibat petir atau peristiwa tertentu, dan memberikan penataan dengan baik terhadap jenis-jenis pohon khas yang telah menjadi program pemerintah setempat yang secara bertahap ditanam di dalam area lingkar Setu Babakan.

Pada sepuluh pekarangan contoh, ditemukan terdapat 4 pekarangan yang memiliki indeks keragaman tinggi dan 6 pekarangan dengan indeks keragaman rendah. Berbeda dengan area lingkar setu, penambahan jumlah dan jenis tanaman päda pekarangan memerlukan adanya persetujuan antara pihak pemilik dan pengelola. Penambahan jumlah dan jenis dapat dilakukan dengan menyesuaikan Fuas area pekarangan yang masih mampu dan sesuai untuk ditanami. Rekomendasi To ưntuk keragaman pohon dapat dilihat di dalam ilustrasi pada Gambar 19.

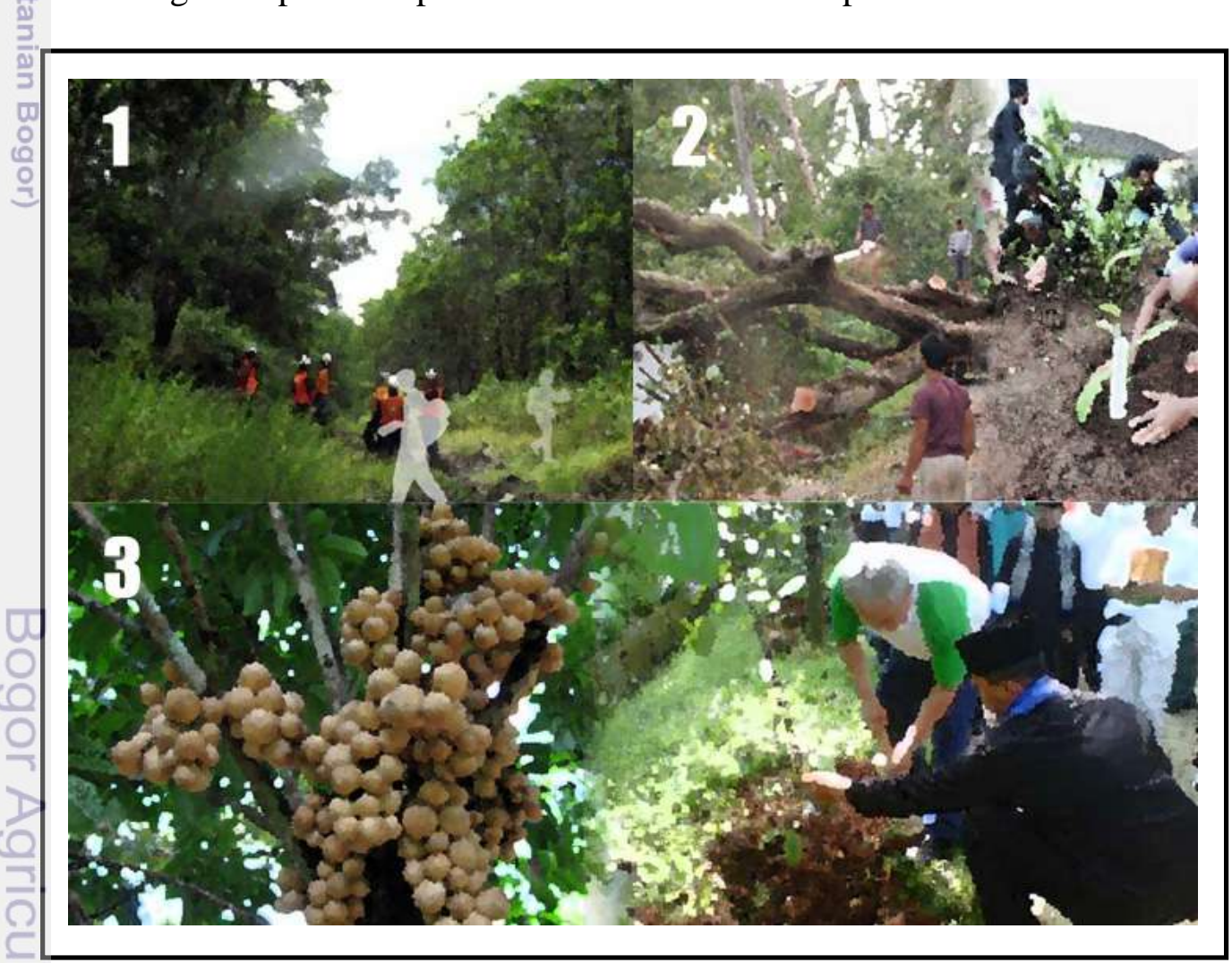

Gambar 19. Rekomendasi keragaman pohon (1) Pemantauan secara rutin (2) Menanam tanaman pengganti (3) Penataan terhadap jenis-jenis pohon khas 


\subsection{Fungsi Ekologis Pohon}

Secara keseluruhan, pohon-pohon yang berada di dalam area lingkar Setu Babakan telah memenuhi kriteria yang baik di dalam memenuhi fungsi ekologisnya, terutama terhadap kenyamanan pengguna di dalam melakukan aktivitas rekreasi mereka. Untuk memperoleh kenyamanan yang lebih maksimal, sebaran kategori sangat baik dapat dijadikan suatu referensi untuk rekomendasi di dalam menetapkan titik-titik tertentu pada kawasan, terutama untuk memfasilitasi p⿳亠丷厂彡ngguna dalam melakukan kegiatan rekreasi seperti duduk-duduk, menikmati pemandangan, bersosialisasi, memancing, pagar alami untuk akses fasilitas rekreasi air dan menikmati makan siang. Rekomendasi untuk kenyamanan têrhadap fungsi ekologis pohon dapat dilihat di dalam ilustrasi pada Gambar 20.

Untuk memperoleh hasil berupa sintesis dari sebaran fungsi ekologis pohon dari total lima aspek utama, yaitu pemodifikasi suhu, pengontrol kelembaban udara, peredam kebisingan, penahan angin, dan untuk menghadirkan satwa burung, maka didapatlah simpulan pada Gambar 21.

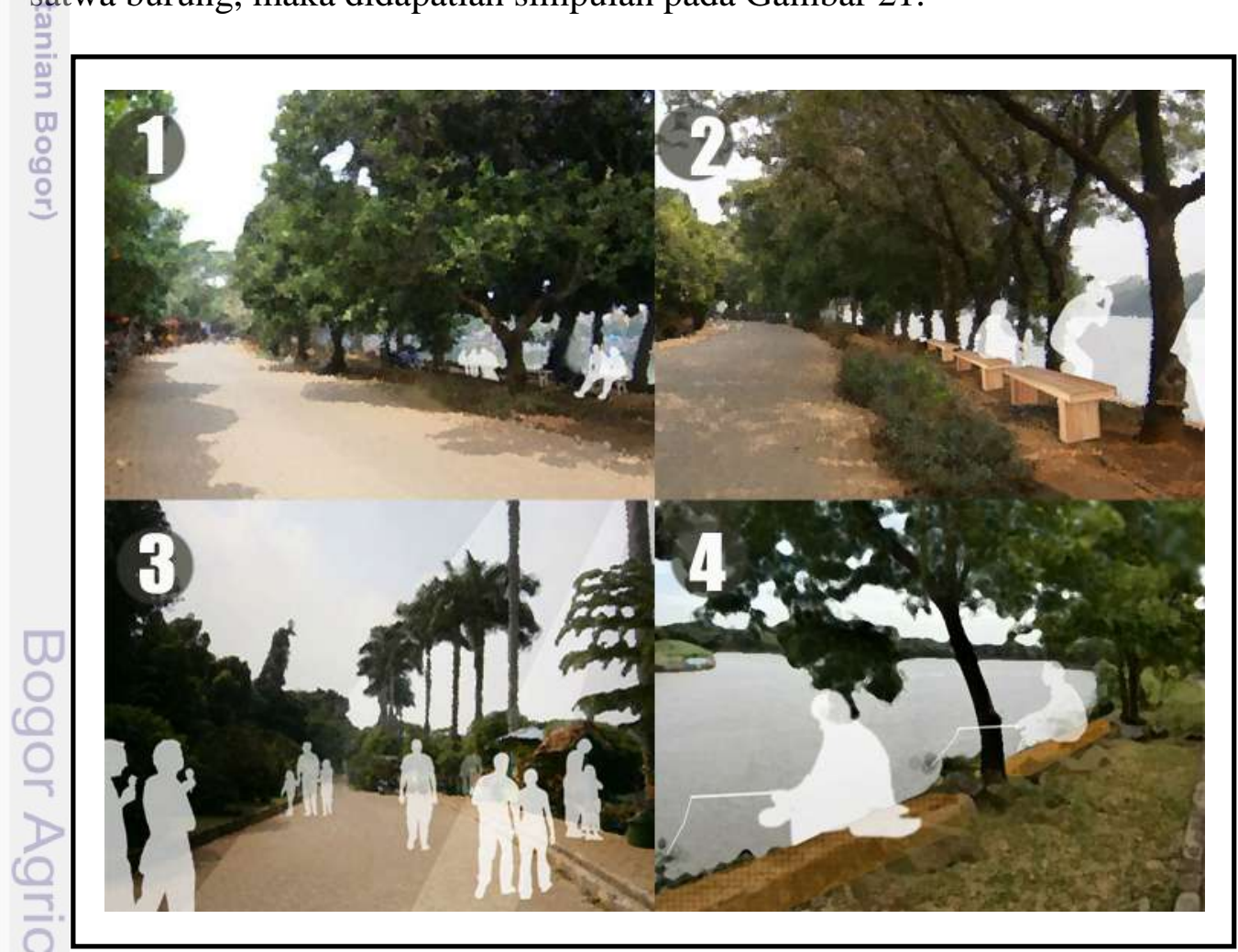

Gambar 20. Rekomendasi fungsi ekologis pohon (1) Duduk-duduk (2) Menikmati pemandangan (3) Akses rekreasi air (4) Memancing 


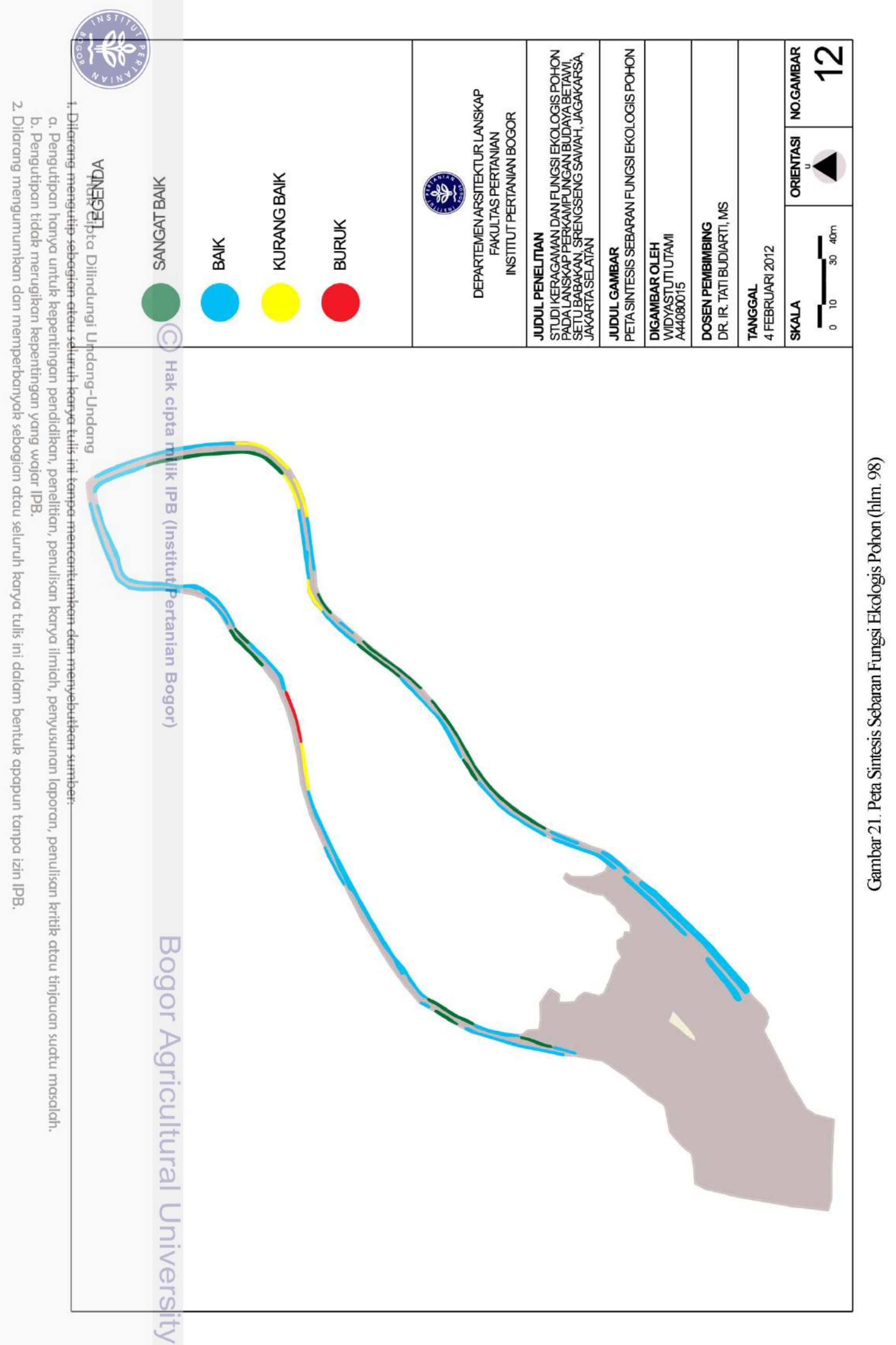


Apabila melihat pada sebaran kategori fungsi ekologis pohon yang terdapat pada peta sintesis, maka dapat dikatakan bahwa secara umum area lingkar Setu Babakan dinaungi oleh pohon-pohon yang tergolong baik di dalam memberikan fungsinya bagi sebuah area rekreasi danau. Akan tetapi, terdapat bagian-bagian tertentu yang terlihat masih kurang maksimal di dalam memberikan fungsinya. Hal ini juga berkaitan dengan kondisi dari aktivitas sosial yang berada di dalam kawasan, seperti memancing, duduk-duduk, mendirikan tenda atau kios măakanan, makan, dan menikmati pemandangan. Aktivitas tersebut tidak terlepas đari kehadiran pohon di dalam memberikan nilai kenyamanan. Rekomendasi terhadap penataan pohon beserta aktivitas rekreasi terkait dapat dilihat pada Gambar 22. 


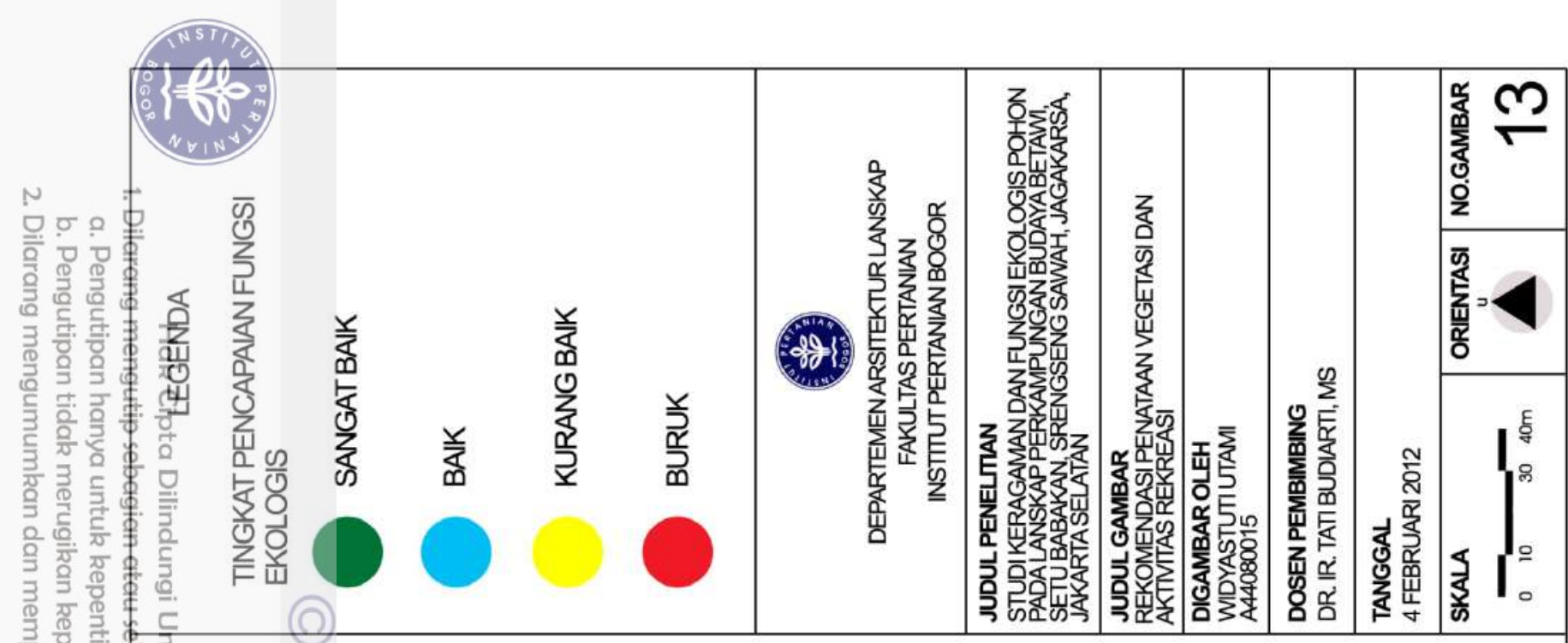

음

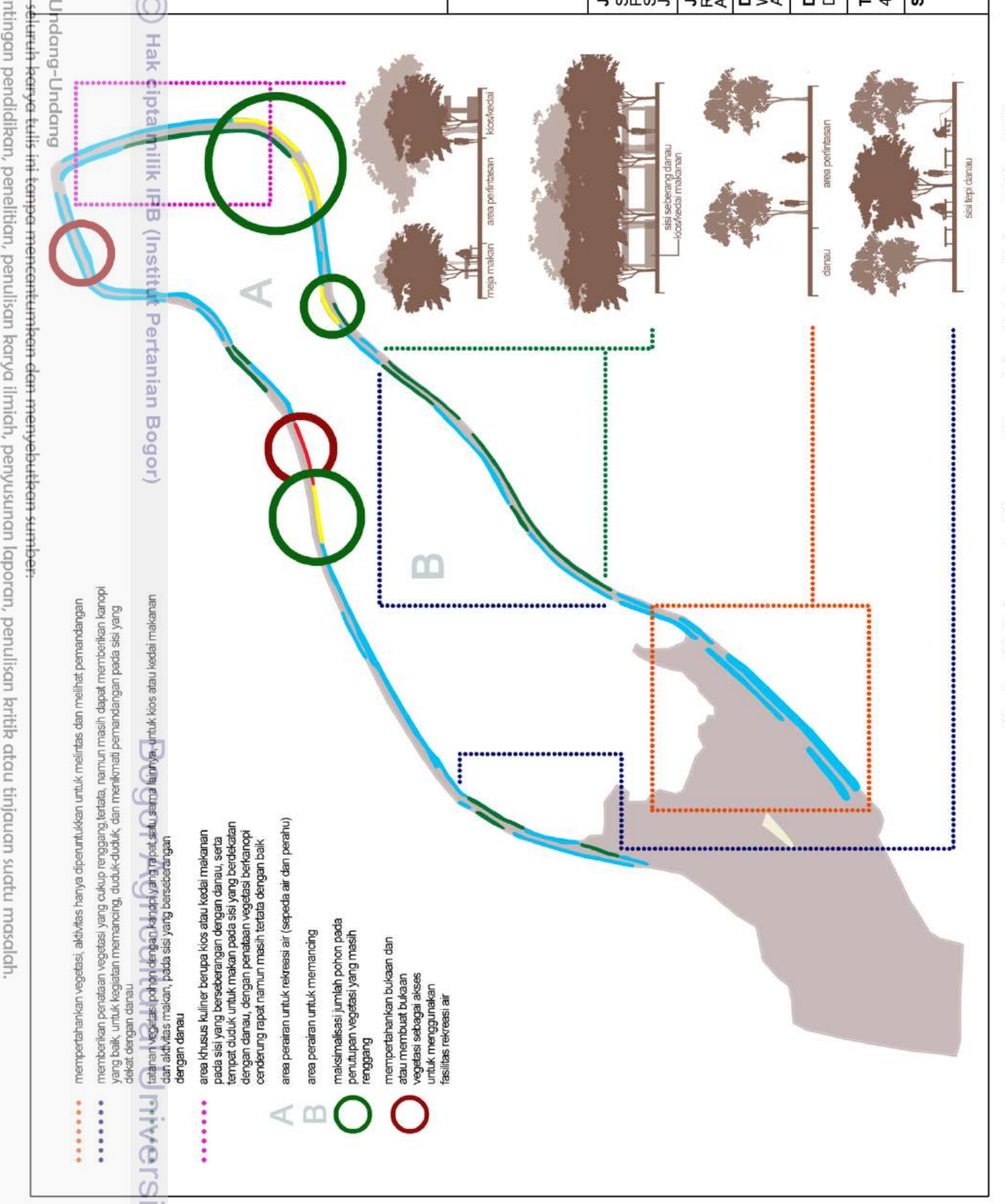

8) 


\section{BAB VII \\ SIMPULAN DAN SARAN}

\subsection{Simpulan}

Pada Perkampungan Budaya Betawi Setu Babakan dengan area lingkar danau dan sepuluh pekarangan sampel sebagai batasan studi pada penelitian ini, ditemukan terdapat 8 jenis tanaman khas Jakarta yang tergolong langka, yang țerdiri dari srikaya, buni, bisbul, kawista batu, rukem, duku condet, mengkudu, đan jamblang. Adapun nilai indeks keragaman vegetasi pohon pada area lingkar danau bernilai 4.23, yang tergolong ke dalam area dengan tingkat keragaman spesies pohon yang tinggi. Untuk nilai keragaman pada sepuluh pekarangan sämpel, ditemukan bahwa terdapat 4 pekarangan yang memiliki tingkat keragaman spesies tinggi dan 6 pekarangan dengan tingkat keragaman spesies sedang.

Penilaian terhadap fungsi ekologis pohon menunjukkan bahwa persentase jumlah tertinggi dengan kategori sangat baik terdapat pada fungsi ekologis pohon pada lanskap area Rekreasi Setu Babakan yang berfungsi sebagai pemodifikasi sûhu, penahan angin, dan habitat untuk kehadiran satwa (burung). Adapun fungsi ekologis dengan mayoritas individu memiliki kategori baik adalah fungsi sebagai peredam kebisingan, sedangkan fungsi sebagai pengontrol kelembaban udara memiliki mayoritas individu pohon pada tapak berkategori buruk.

\subsection{Saran}

Penelitian ini diharapkan mampu menjadi sebuah referensi bagi rencana dan pengelolaan konservasi pohon baik pada area lingkar danau maupun (pekarangan sebagai kawasan inti rekreasi Perkampungan Budaya Betawi Setu Babakan. Besarnya potensi yang dimiliki oleh kawasan sangat patut untuk tidak hanya pengelola beserta pemerintah daerah setempat saja yang bertindak untuk memperhatikan dan mengembangkan area rekreasi tersebut, melainkan juga masyarakat setempat di dalam meningkatkan potensi kawasan dengan turut serta mempelajari dan mengedukasi wisatawan dari luar daerah terkait jenis-jenis pohon khas Jakarta serta pohon-pohon bervarietas unggul. 


\section{DAFTAR PUSTAKA}

Aisah S, Tandjung SD, Hadisusanto S. 2002. Kajian Vegetasi sebagai Peredam Kebisingan yang Ditimbulkan oleh Kereta Api Di Kecamatan Gamping, Kabupaten Sleman, D.I Yogyakarta [naskah penelitian]. Program Pascasarjana Universitas Gajah Mada, Yogyakarta

Badan Meteorologi dan Geofisika Stasiun Klimatologi Pondok Betung. 2009. Laporan Cuaca

Badan Meteorologi dan Geofisika Stasiun Klimatologi Pondok Betung. 2010. Laporan Cuaca

Badan Meteorologi dan Geofisika Stasiun Klimatologi Pondok Betung. 2011. Laporan Cuaca

Bianpoen C. 1989. Fungsi Taman dalam Kota [naskah laporan]. Pusat Penelitian Teknologi dan Pemukiman Universitas Tarumanegara, Jakarta.

Booth NK, Hiss EJ. 2005. Residential Landscape Architecture : Design Process for The Private Residence. New Jersey: Pearson Prentice Hall

Boyd, C.E. 1990. Water Quality in Ponds for Aquaculture. Alabama Agricultural Experiment Station. Auburn University, Alabama

Carpenter PL, Walker TD, Lanphear FO. 1975. Plants In The Landscape. San Fransisco : W.H. Freeman and Company

Coder RD. 1996. Identified benefits of community trees and forests [editorial]. Consolidating and Communicating Urban Forest Benefits

Dahlan, EN. 1992. Membangun Kota Kebun (Garden City) Bernuansa Hutan Kota. Bogor: IPB Press dan Sekolah Pascasarjana IPB

Departemen Kesehatan RI. 1995. Petunjuk Pelaksanaan Pengawasan Kebisingan. Jakarta: Departemen Kesehatan RI

Dinas Pemakaman dan Pertamanan DKI Jakarta. 2011. Perencanaan Penghijauan Jalur Koridor burung di wilayah DKI Jakarta. 109 hal

Dinas Pertanian dan Kehutanan. 2009. Laporan Status Lingkungan Hidup Daerah Provinsi DKI Jakarta.345 hal

Direktorat Geologi. 1969. Peta Geologi Jawa dan Madura. Lembar Jawa Barat, Skala 1:500.000. Cetakan ke tiga. Bandung 
Direktorat Jenderal Bina Marga. 1996. Tata Cara Perencanaan Teknik Lanskap Jalan. Departemen Pekerjaan Umum. Jakarta: Direktorat Jenderal Bina Marga.

Droste B, Plachter H, Rossler M.1995. Cultural Landscapes of Universal Value. New York: Gustav Fischer Verlag Jena, Stuttgart, in cooperation with UNESCO

Fakuara, Y. 1982. Hutan Kota Ditinjau dari Aspek Nasional. Seminar Hutan Kota DKI Jakarta

F

Finchmania. 2012. Bondol Jawa. Finchmania [internet]. http://www.finchmania.blogspot.com/2012/02/bondol-jawa.html (5 Februari 2012)

Finchmania. 2012. Bondol Peking. Finchmania [internet]. http://www.finchmania.blogspot.com/2012/02/bondol-peking.html (5 Februari 2012)

Grrey GW, Deneke FJ. 1978. Urban Forestry.Wiley J, Sons, editor. New York: Library of Congress Cataloging in Publication Data

Harmoni, Ati. 1994. Pengantar Ilmu Ilmiah Dasar. Jakarta: Penerbit Gunadarma [Publikasi, Lecturer Notes]

Herawati M. 1982. Perlakuan Jumlah Baris dan Pola Tanam Kembang Sepatu dalam Fungsinya Mereduksi Kebisingan dan Aplikasi dalam Pertamanan. Bogor: Institut Pertanian Bogor

Hernowo JB, Prasetyo LB. 1989. Konsepsi Ruang Terbuka Hijau di Kota sebagai Pendukung Pelestarian Burung. Media Konservasi II (4) : 61-71

Hidayat, I. 2008. Evaluasi Jalur Hijau Jalan Sebagai Penyangga Lingkungan Sekitarnya dan Keselamatan Pengguna Jalan Bebas Hambatan Jagorawi [Thesis]. Bogor: Sekolah Pascasarjana, Institut Pertanian Bogor.

Keputusan Menteri Negara Lingkungan Hidup. Nomor : KEP48/MENLH/11/1996 tentang Baku Tingkat Kebisingan

Łaporan Status Lingkungan Hidup Daerah Provinsi DKI Jakarta. 2011. Pemerintah Provinsi DKI Jakarta

Eucas, PHC.1992. Protected Landscapes, A Guide For Policy Makers and Planners. London: CHAPMAN \& HALL

Moechtar MS, Sarwadana SM, Semarajaya CGA. 2012. Identifikasi Pola Permukiman Tradisional Kampung Budaya Betawi Setu Babakan, Kelurahan Srengseng Sawah, Kecamatan Jagakarsa, Kota Administrasi 
Jakarta Selatan, Provinsi DKI Jakarta [e-jurnal]. Denpasar: Universitas Udayana

Odum EP. 1998. Dasar-dasar Ekologi. Edisi ke-3. Samingan T, penerjemah. Yogyakarta (ID): Universitas Gadjah Mada Press. Terjemahan dari: Fundamentals of Ecology

Oke TR. 1989. The micrometeorology of the urban forest [catatan penelitian]. Philos T Roy Soc B. 324(1223):335-349

Olive. 2011. Mengajak Burung Mampir Ke Rumah. Burung Indonesia [internet]. (http://burung.org/Artikel/mengajak-burung-mampir-ke-rumah.html (5 Mei 2011)

Pauleit S, Duhme F. 2000. GIS assessment of Munich's urban forest structure for urban planning [catatan penelitian]. J Arboriculture. 26(3):133-141

Peraturan Menteri Pekerjaan Umum Nomor: 05/PRT/M/2008, tentang Pedoman Penyediaan dan Pemanfaatan Ruang Terbuka Hijau Di Kawasan Perkotaan

Peraturan Pemerintah Nomor: 82/2001 tentang Baku Mutu Air

Rafi’I, Suryatna. 1995. Meteorologi dan Klimatologi. Bandung: Angkasa 光

Siregar, EA. 2012. Jasa Lanskap Pekarangan Bagi Habitat Satwa Burung Di Kota Bogor [Skripsi]. Bogor: Institut Pertanian Bogor

Soerianegara I, Indrawan A. 2008. Ekologi Hutan Indonesia. Bogor: InstitutPertanian Bogor

Surat Keputusan Gubernur DKI Jakarta Nomor: 9/2000

Surat Keputusan Gubernur DKI Jakarta Nomor: 2359/1987 tentang Tanaman yang Dilindungi

USDA National Agroforestry Center. 1997. Trees as Noise Buffers. Elevitch C, editor. USA: The Overstory

Wardiningsih, Sitti. 2005. Rencana Pengelolaan Lanskap Perkampungan Budaya Betawi Di Setu Babakan-Srengseng Sawah, Kecamatan JagakarsaJakarta Selatan [Thesis]. Bogor: Sekolah Pasca Sarjana, Institut Pertanian Bogor

Washington State University (WSU). 2003. Trees against the wind. A Pacific Northwest Extension Publication. PNW0005. pp: 40

YAI dan BAPPEDA DKI. 2001.Penyusunan Strategi dan Program Penghijauan. Jakarta 
Yayasan Kutilang Indonesia. 2012. Daftar Jenis Pohon untuk Habitat Burung. Kutilang Indonesia, For Bird Conservation. (http://www.kutilang.or.id/burung/konservasi/daftar-jenis-pohon-untukhabitat-burung/\#. Yayasan Kutilang Indonesia 2012) 


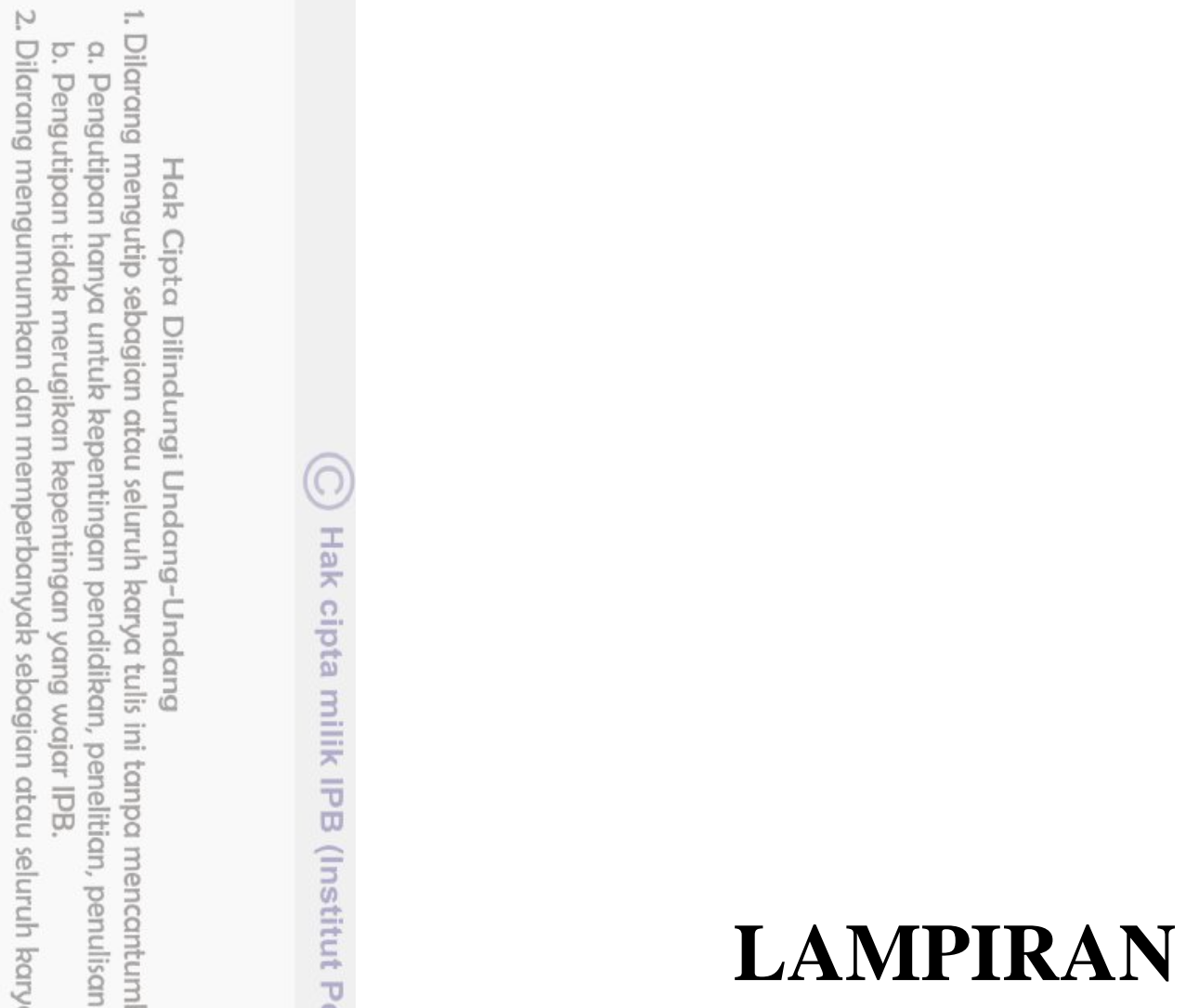


Lampiran 1. Baku Tingkat Kebisingan

\author{
KEPUTUSAN \\ MENTERI NEGARA LINGKUNGAN HIDUP \\ NOMOR : KEP-48/MENLH/11/1996 \\ TENTANG \\ BAKU TINGKAT KEBISINGAN \\ TANGGAL 25 NOPEMBER 1996
}

BAKU TINGKAT KEBISINGAN

\title{
Peruntukan
}

Kawasan/

Līngkungan Kegiatan

Peruntukan Kawasan

1. Perumahan dan Pemukiman 55

2. Perdagangan dan Jasa 70

3. Perkantoran dan Perdagangan 65

4. Ruang Terbuka Hijau 50

5. Industri 70

6. Pemerintahan dan Fasilitas Umum 60

$\begin{array}{ll}\text { 7. Rekreasi } & 70\end{array}$

8. Khusus:

- Bandar Udara

- Stasiun Kereta Api

- Pelabuhan Laut $\quad 70$

- Cagar Budaya $\quad 60$

b. Lingkungan Kegiatan

1. Rumah Sakit atau sejenisnya $\quad 55$

2. Sekolah atau sejenisnya 55

3. Tempat ibadah atau sejenisnya 55

Keterangan :

") disesuaikan dengan ketentuan Menteri Perhubungan 
Lampiran 2. Jenis-Jenis Vegetasi (Pohon dan Semak) yang Cocok sebagai Habitat Burung

\begin{tabular}{|c|c|c|c|}
\hline No & Nama Latin & Nama Lokal & Status \\
\hline 1 & Agathis damara & Damar & \\
\hline 2 & Aglaia odorata & Culan & \\
\hline 3 & Albizia sp & Albisia & \\
\hline 4 & Aleurites moluccana & Kemiri & \\
\hline 05 & Alstonia scholaris & Pule & \\
\hline \pm 6 & Antidesma bunius & Buni & \\
\hline$\frac{1}{\pi} 7$ & Andropogon sorghum & Gendrung & \\
\hline$\frac{\Omega}{7} 8$ & Areca catechu & Pinang & \\
\hline 9 & Areca latiloba & Jambu rende & \\
\hline 10 & Areca vertiora & Pinang Yahi & \\
\hline$\overline{\bar{\lambda}} 11$ & Arenga pinnata & Aren & \\
\hline 12 & Arundo donax & Kaso belang & \\
\hline Э13 & Averhoa bilimbi & Belimbing sayur & \\
\hline$\stackrel{n}{7}=$ & Baccaurea racemosa & Menteng & \\
\hline$c_{15}$ & Bambusa vulgaris & Bambu kuning & \\
\hline 16 & Barringtonia asiatica & Keben & \\
\hline 17 & Bauhinia purpurea & Bunga kupu-kupu & \\
\hline 18 & Bixa orellana & Galinggem & \\
\hline 19 & Bouea macrophylla & Gandaria & Langka \\
\hline @20 & Bougainvillea glabra & Bugenvil & \\
\hline 21 & Calliandra surinamensis & Kaliandra & \\
\hline 22 & Callophyllum inopphyllum & Nyamplung & \\
\hline 23 & Cananga odorata & Kenanga & \\
\hline 24 & Canarium decumanum & Kenari babi & \\
\hline 25 & Carmona relusa & Serutan & \\
\hline 26 & Caryota mitis & Palem ekor ikan & \\
\hline 27 & Ceiba pentandra & Kapuk randu & \\
\hline 28 & Chrysophyllum cainito & Sawo duren & Langka \\
\hline 29 & Cinnamomum burmanii & Kayu manis & \\
\hline 030 & Cinnamomum inners & Kiteja & \\
\hline 31 & Clidemia hirta & Harendong lelaki & \\
\hline & Cinometra cauliflorn & Namnam & Langka \\
\hline & Corypha gebanga & Gebang & \\
\hline & Cordia obligua & Kendal & \\
\hline & Cyrtotachys lacca & Palem merah & \\
\hline & Dillenia philippinensis & Sempur & Langka \\
\hline 37 & Diospyros philippinensis & Bisbul & \\
\hline 38 & Elaeocarpus grandiflorus & Anyang-anyang & \\
\hline 39 & Erythrina christagalli & Dadap & \\
\hline 40 & Erythrina variegata & Dadap belang & \\
\hline
\end{tabular}


Lengkeng

Beringin

Biola cantik

Preh

Gondang

Rukem

Mundu

Kacapiring

Bambu tali

Bambu hitam

Melinjo

Dangdeur

Pisang hias

Gayam

Melati

Lengkuas

Cente

Palem kool

Alkesa

Bunga sepatu kecil

Sawo

Sawo kecik

Langka

Sapu tangan

Lompeni

Harendong bokor

Harendong

Nagasari

Langka

Kantil

Langka

Cempaka

Langka

Langka

Harendong gede

Tanjung

Murbei

Pace

Bunga irian

Kemuning

Pisang seribu

Pala

Kersen

Palem raja

Oksosperma

Palakium

Kluwak

Perikopsis

Cermai 
85 Pigaffeta filaris

86 Pithecolloblum dulce

87 Podocarpus nerifolius

88 Pometia pinnata

89 Prychosperma macarthurii

90 Salacca zalaca

91 Samanea saman

92 Sandoricum kotjape

(93) Santalum album

794 Sesbania grandiflora

95 Spothodea campanulata

966 Spondias dulcis

97 Stelecocarpus burahol

98 Sterculia foetida

99 Swietenia macrophylla

100 Syzygium aquaeum

$\overline{1} 01$ Syzygium aromaticum

102 Syzygium cummune

103 Syzygium jambos

904 Syzygium malaccensis

905 Syzygium polyathum

106 Syzygium polycephalum

107 Talauma condolii

G908 Terminalia catappa

109 Trema orientalis

110 Triphasia trifolia

111 Ristellateia australasiae

112 Vitex sp

113 Zingiber officinale

114 Zyzypus jujuba
Wanga

Pete

Podocarpus

Matoa

Palem hijau

Salak

Ki hujan

Kecapi

Langka

Cendana

Turi

Spatodea

Kedondong

Kepel

Kepuh

Mahoni

Jambu air

Cengkeh

Jamblang

Jambu mawar

Jambu bol

Salam

Gowok

Langka

Cempaka gondok

Ketapang

Angrung

Jeruk kingkit

Hujan emas rambut

Laban

Jahe

Widara

Sumber : Booklet Taman Burung Taman Mini Indonesia Indah, van Balen 1989 
Lampiran 3. Jenis-Jenis Pohon pada Area Studi Perkampungan Budaya Betawi Setu Babakan

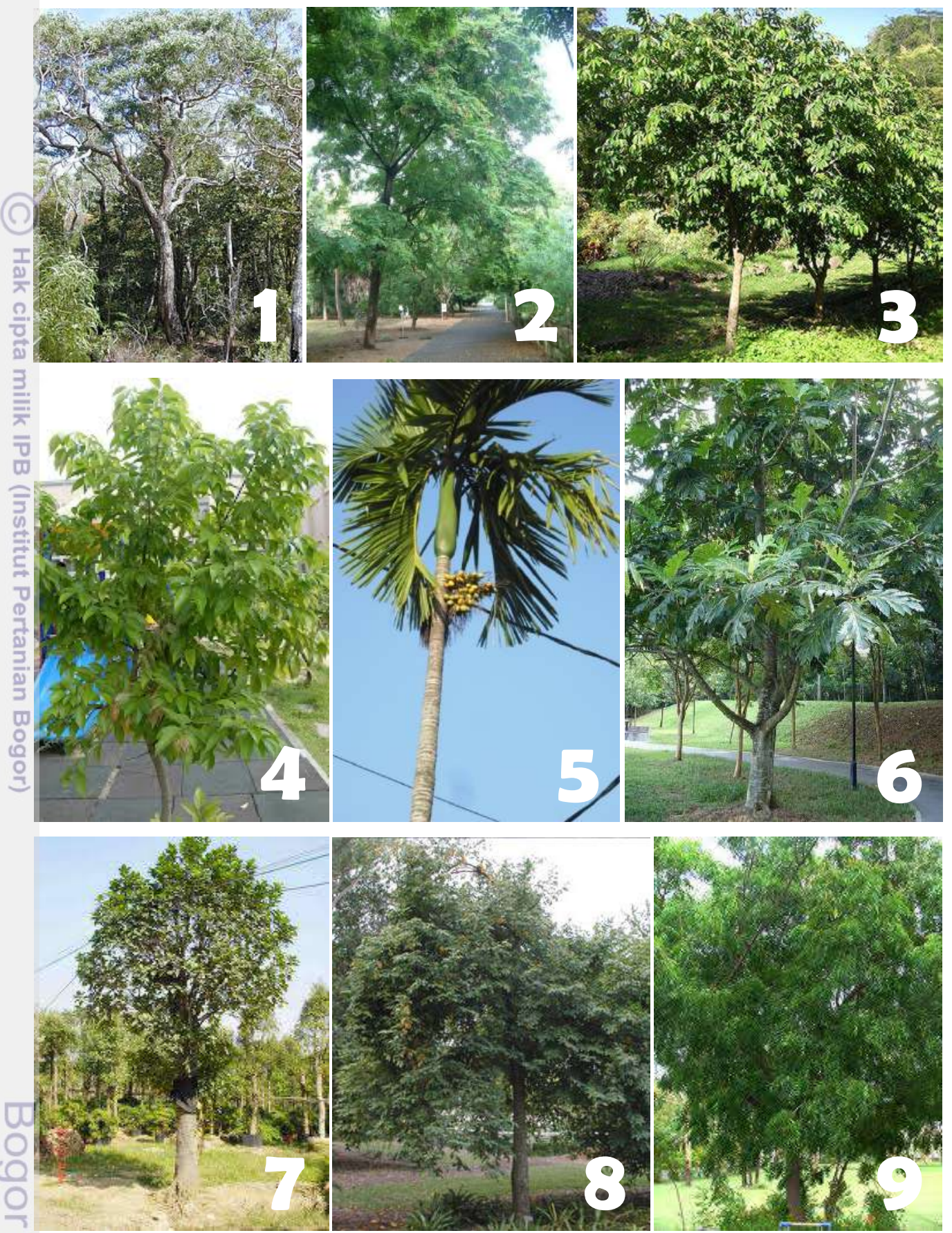



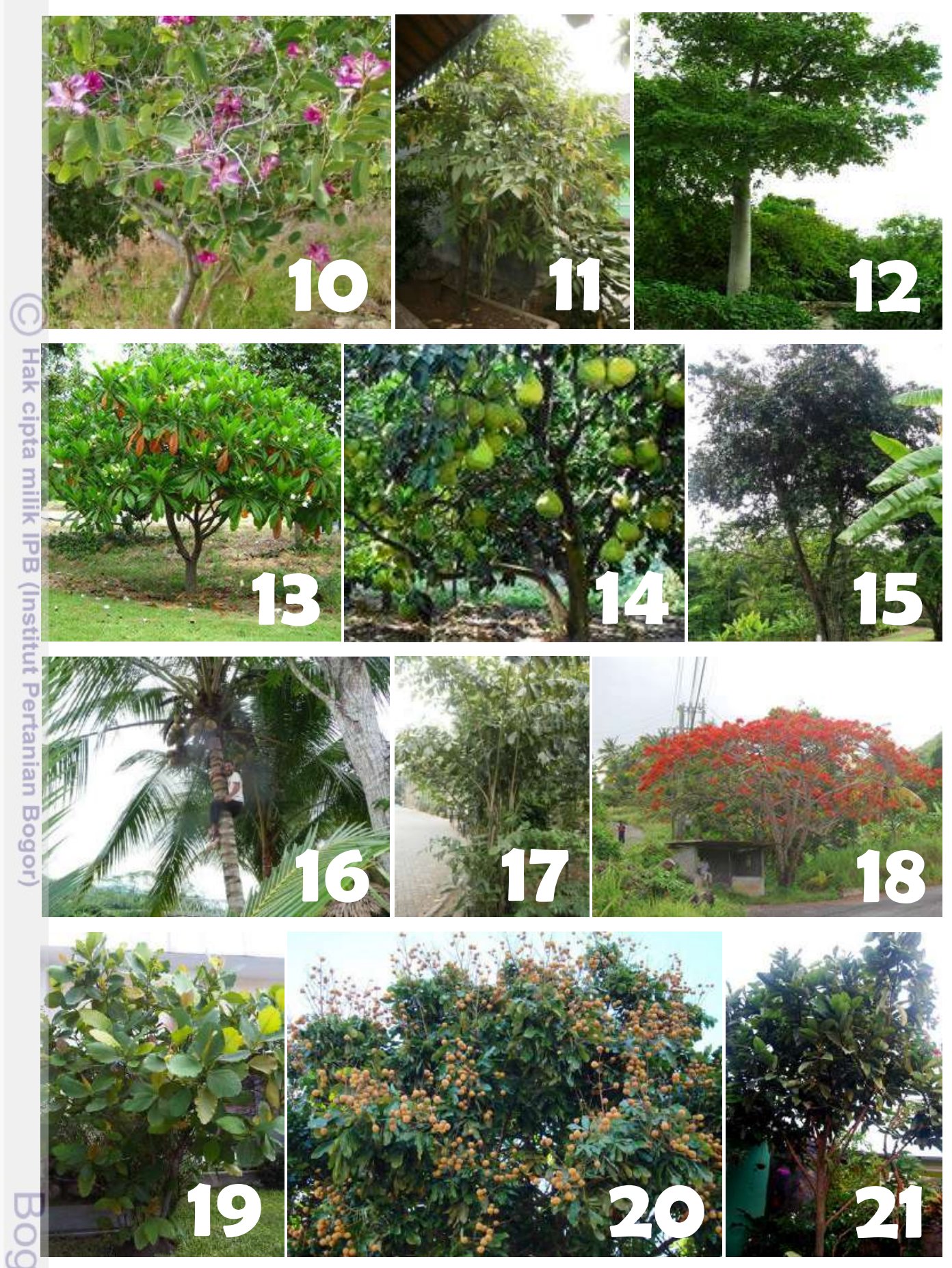

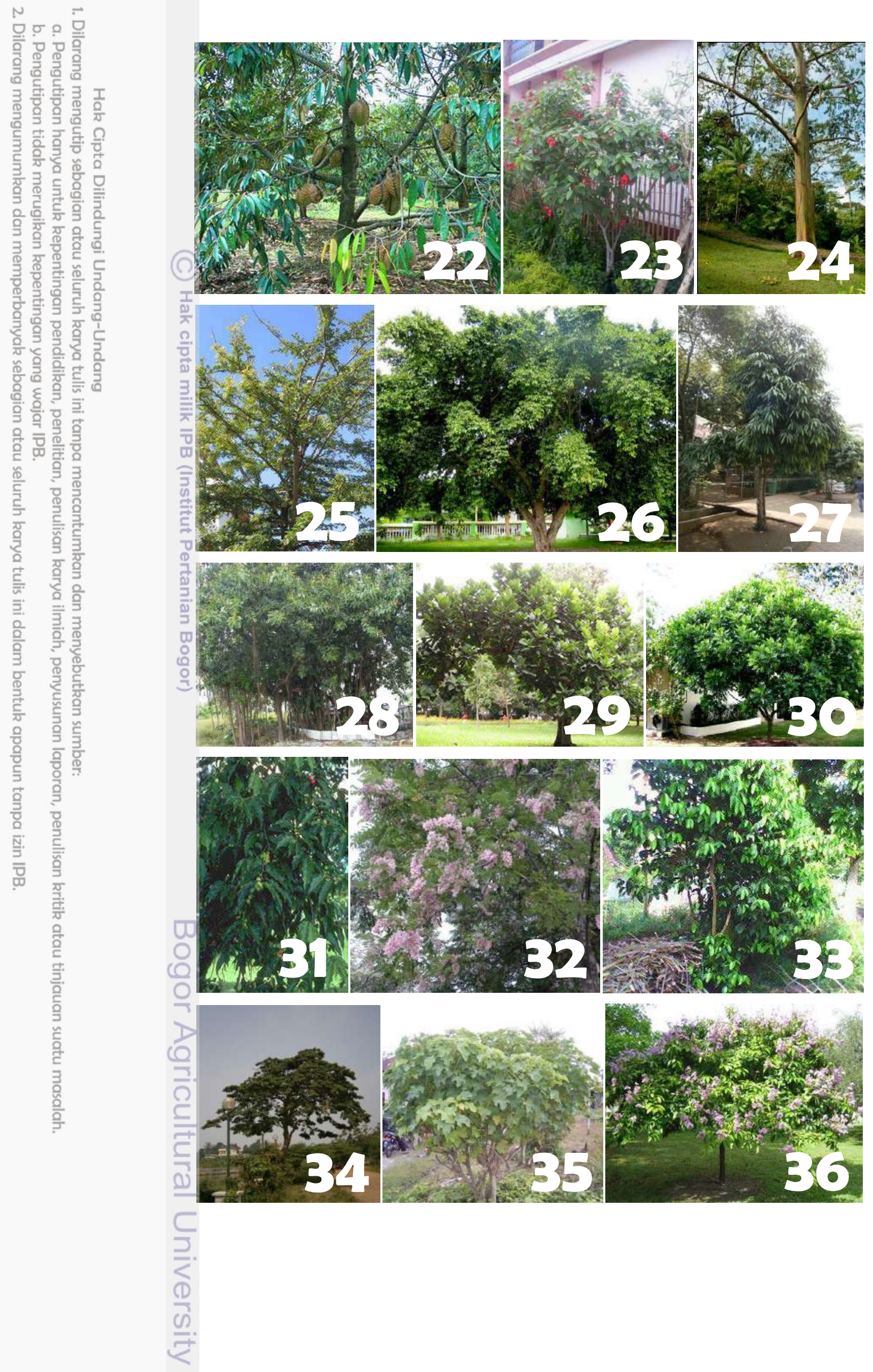

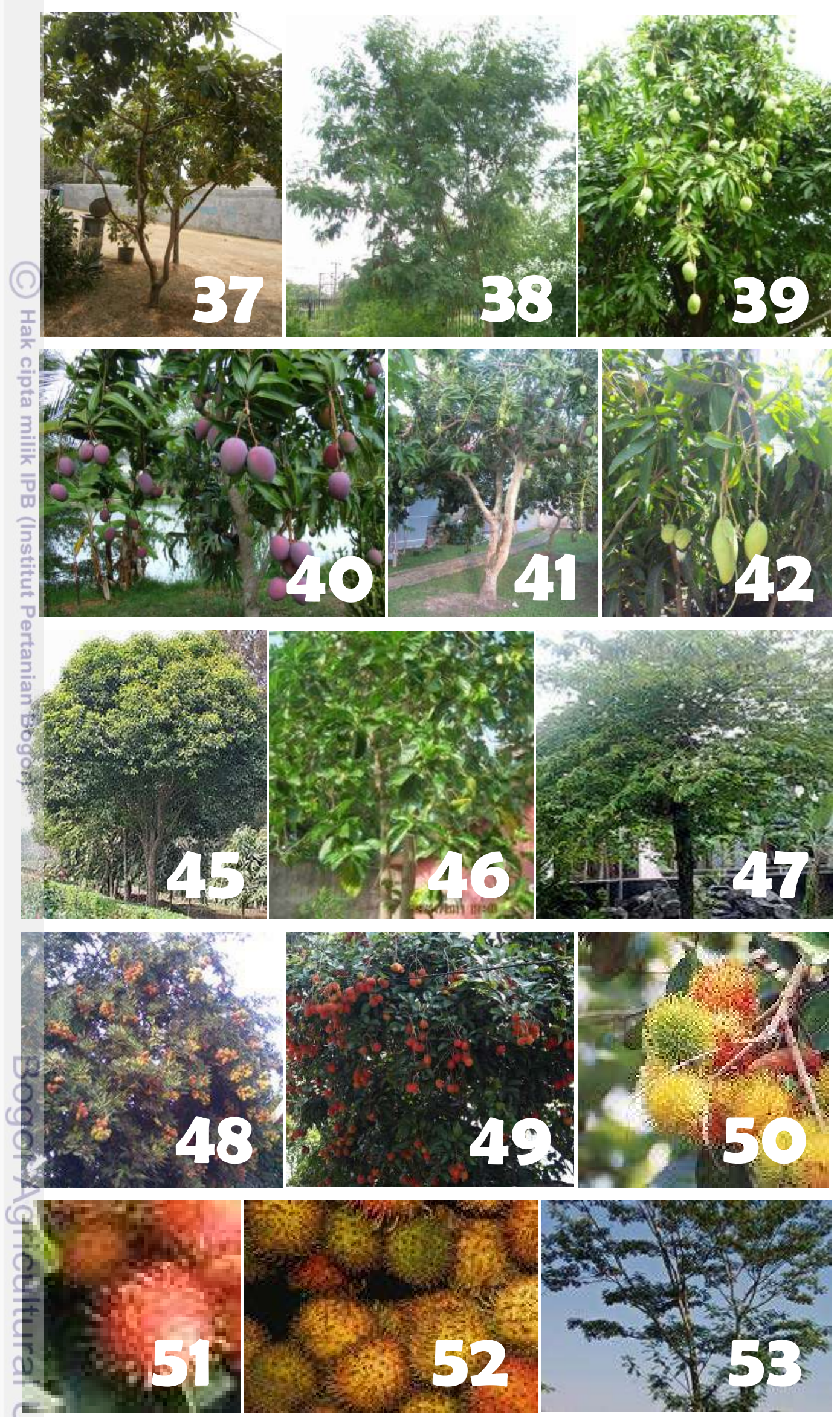

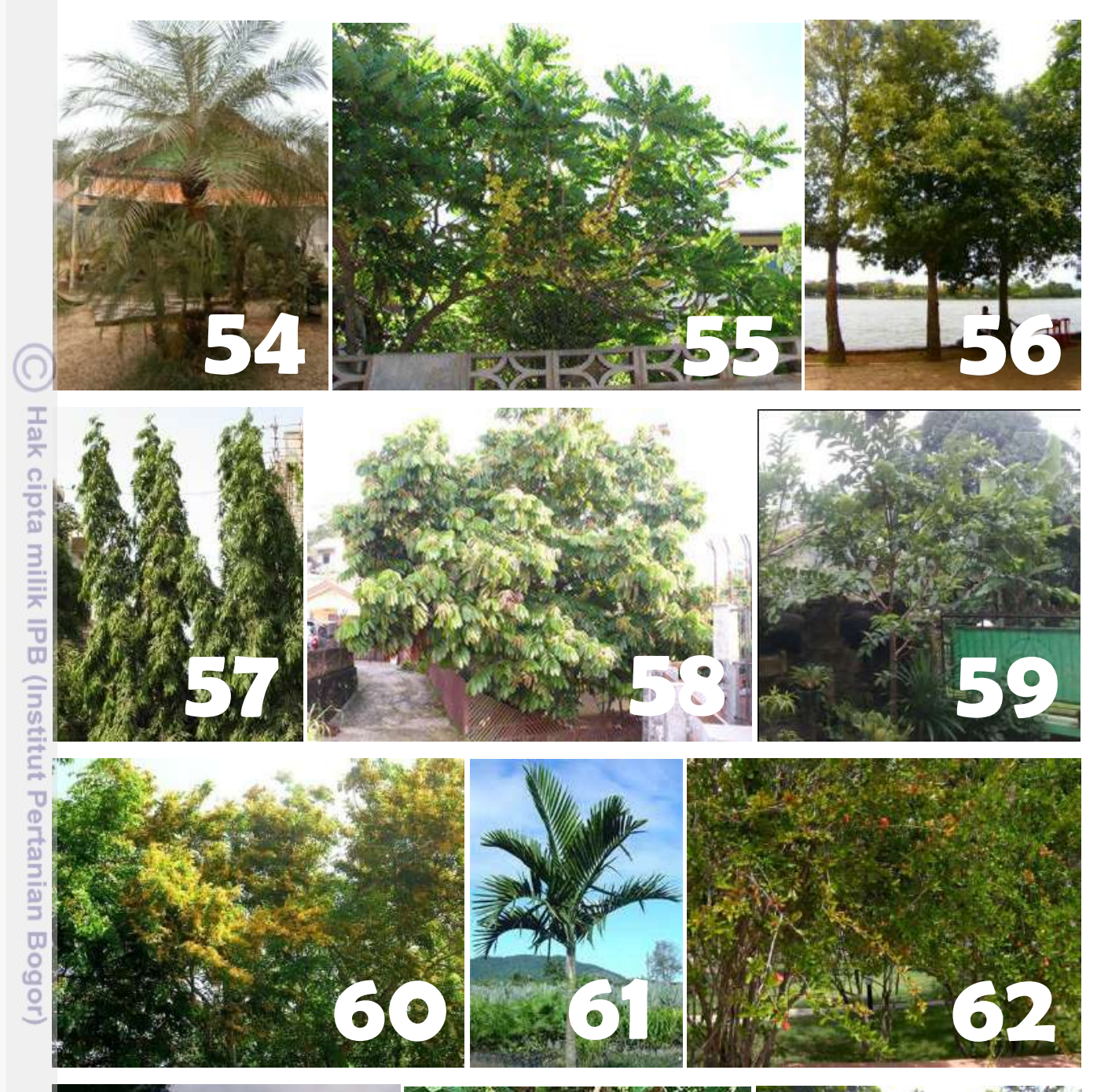

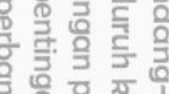

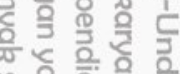

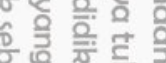

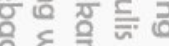

을 을

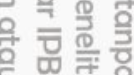



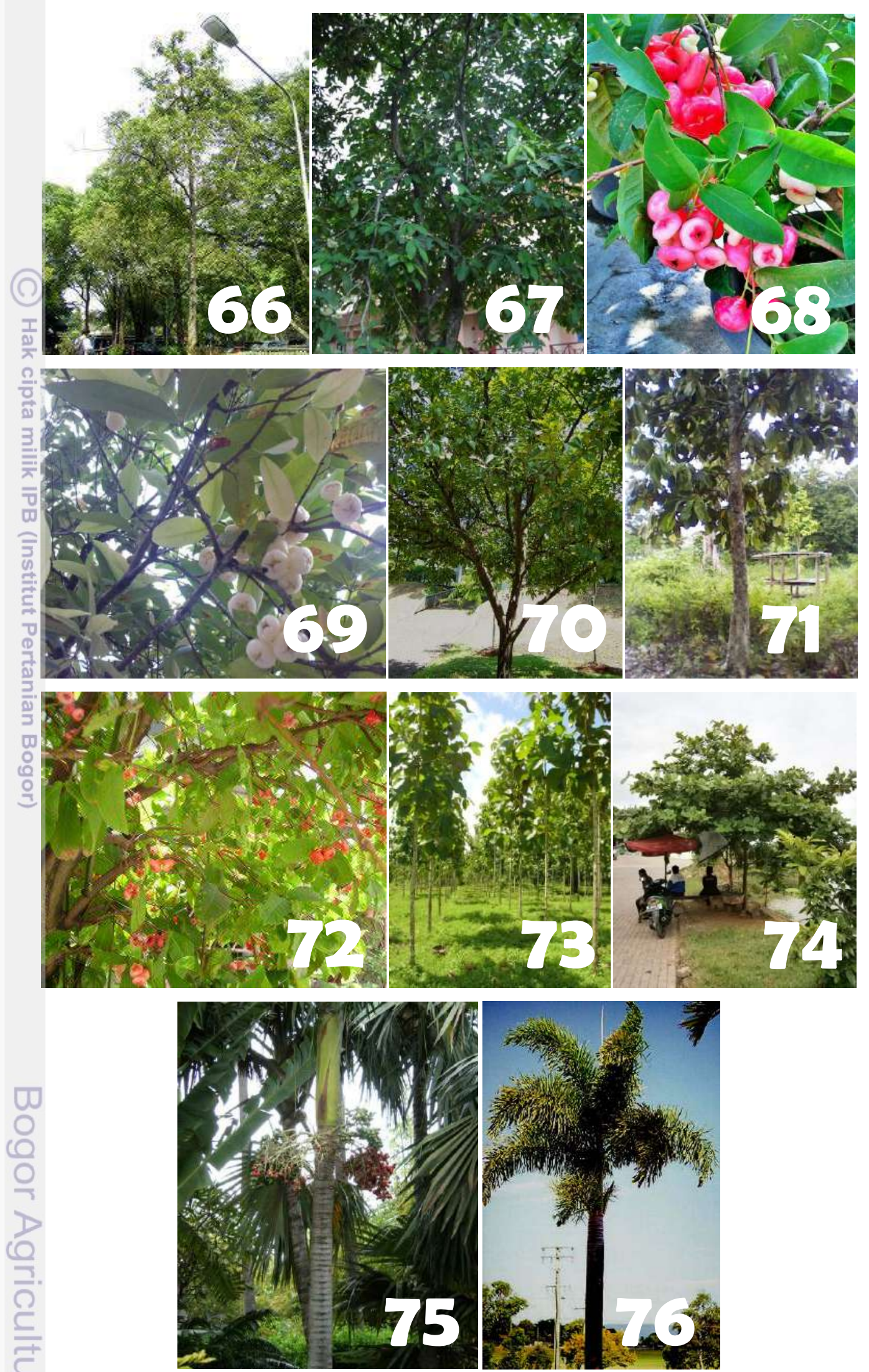
Tabel Keterangan Jenis-Jenis Pohon pada Area Studi Perkampungan Budaya Betawi Setu Babakan

\begin{tabular}{|c|c|c|c|c|}
\hline No & Nama Latin & Nama Lokal & Lingkar Setu & Pekarangan \\
\hline 1 & Acacia longifolia & Akasia & $v$ & \\
\hline 2 & Adenanthera pavonina & Saga & v & \\
\hline 3 & Annona squamosa & Srikaya & & v \\
\hline 4 & Antidesma bunius & Buni & $\mathrm{v}$ & \\
\hline 5 & Areca catechu & Pinang & & v \\
\hline 16 & Artocarpus altilis & Sukun & $\mathrm{v}$ & \\
\hline 궂 & Artocarpus heterophyllus & Nangka & $\mathrm{v}$ & v \\
\hline$\frac{9}{7} 8$ & Averrhoa carambola & Belimbing & $v$ & $v$ \\
\hline 99 & Azadirachta indica & Mimba & $v$ & \\
\hline 10 & Bauhinia purpurea & Kupu-kupu & v & \\
\hline 11 & Cananga odorata & Kenanga & & $v$ \\
\hline 12 & Ceiba pentandra & Kapuk randu & $v$ & \\
\hline$\exists 3$ & Cerbera manghas & Bintaro & $\mathrm{v}$ & \\
\hline 14 & Citrus maxima & Jeruk bali & & $v$ \\
\hline-15 & Crateva religiosa & Sawo duren & v & v \\
\hline 16 & Cocos nucifera & Kelapa & $v$ & \\
\hline 17 & Coryota mitis & Palem ekor ikan & & v \\
\hline 18 & Delonix regia & Flamboyan & $v$ & \\
\hline 19 & Dillenia sp. & Sempur & $v$ & \\
\hline 20 & Dimocarpus longan & Lengkeng & & $\mathrm{v}$ \\
\hline 21 & Diospyros blancoi & Bisbul & v & \\
\hline 22 & Durio zibethinus & Durian montong & & $v$ \\
\hline 23 & Erythrina crista-galli & Dadap merah & v & \\
\hline 24 & Eucalyptus deglupta & Rainbow eucalyptus & $v$ & \\
\hline 25 & Feronia lucida & Kawista batu & $v$ & v \\
\hline 26 & Ficus benjamina & Beringin & v & v \\
\hline 27 & Ficus binnendykii & Akar ara & v & \\
\hline 28 & Ficus elastica & Beringin karet & $v$ & \\
\hline 29 & Ficus lyrata & Biola cantik & v & \\
\hline 0 & Filicium decipiens & Kerai payung & v & \\
\hline & Flacourtia rukam & Rukem & & $v$ \\
\hline & Gliricidia sp. & Gamal & $v$ & \\
\hline & Gnetum gnemon & Melinjo & v & v \\
\hline & Hura crepitans & Pohon roda & v & \\
\hline & Jatropha curcas & Jarak pagar & v & \\
\hline & Lagerstromia speciosa & Bungur & $v$ & \\
\hline 37 & Lansium domesticum & Duku condet & & v \\
\hline 38 & Leucaena leucocephala & Lamtoro & v & \\
\hline 39 & Mangifera indica & Mangga & $\mathrm{v}$ & \\
\hline 40 & Mangifera indica & Mangga (apel) & & $v$ \\
\hline
\end{tabular}


41 Mangifera indica

42 Mangifera indica

43 Manilkara zapota

44 Manilkara zapota

45 Mimusoph elengi

46 Morinda citrifolia

47

Terminalia catappa

Veitchia merilii

Wodyetia bifurcata
Mangga (arum manis) v

Mangga (okyong)

Sawo manila (betawi)

Sawo manila (kulon)

Tanjung

Mengkudu

Kersen

Rambutan (aceh)

Rambutan (binjai)

Rambutan (cimacan)

Rambutan (cipelat)

Rambutan (rapiah)

Sengon

Palem phoenix

Cermai

Glodogan bulat

Glodogan tiang

Matoa

Jambu batu

Angsana

Palem hijau

Delima

Palem raja

Kecapi

Mahoni

Salam

Jambu air

Jambu air (kancing)

Jambu air (putih)

Jamblang

Jambu bol

Jambu air semarang (cincolo)

Jati

Ketapang

Palem putri

Palem ekor tupai
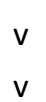

v

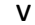

v

v

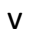

v

v

v

v

$v$

v

v

v

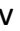

$v$

v

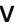

v

v

$v$

$\mathrm{v}$

v

v

Akar ara (Ficus binnendykii)

Pohon ini termasuk ke dalam kerabat beringin, tingginya dapat mencapai 20 meter. Daunnya memiliki bentuk lonjong hingga lanset dan pada bagian ujungnya meruncing dan berwarna hijau. Buah berbentuk bulat agak gepeng, berwarna kuning hingga kemerahan saat masak, dan muncul pada ketiak daun. 


\section{- Akasia (Akasia longifolia)}

Pada lingkungan yang tepat, tanaman ini dapat mencapai ketinggian 30-40 meter dengan diameter batang 80-100 cm, tergolong ke dalam pohon tinggi dengan ukuran tajuk yang cukup besar. Warna kayunya bervariasi dari cokelat sampai merah gelap. Bunganya berwarna kuning terang. Fungsi pohon ini antara lain sebagai point of interest, tanaman pengarah jalan yang menarik, dan tanaman peneduh.

\section{Angsana (Pterocarpus indicus)}

Pohon angasana dapat mencapai ketinggian hingga 40 meter, dengan tajuk lebat seperti kubah. Daunnya berbentuk majemuk menyirip gasal dengan panjang antara 12 sampai $30 \mathrm{~cm}$. Batang pohon ini sering beralur atau berbonggol, biasanya dengan akar papan. Kayunya tergolong keras hingga keras-sedang, berat-sedang, liat dan lenting. Angasana juga memiliki bunga yang berkumpul dalam malai di ketiak serta buah polong bundar yang pipih.

Belimbing (Averrhoa carambola)

Pohon belimbing tergolong ke dalam pohon sedang, dengan ketinggian mencapai 5 meter, dengan pertumbuhannya tidak terlalu banyak membutuhkan sinar matahari. Daunnya majemuk dengan panjang mencapai $50 \mathrm{~cm}$, berbunga merah muda yang biasa muncul pada ujung dahan. Buah tanaman ini memiliki warna kuning kehijauan.

- Beringin (Ficus benjamina)

Beringin tergolong ke dalam pohon tinggi, yang ketinggiannya dapat mencapai 25 meter, dengan diameter batang hingga 2 meter. Batangnya tegak dan bulat, permukaan kasar dan berwarna coklat kehitaman. Tajuk pohon besar berdaun lebat. Daunnya tunggal berwarna hijau, panjang 3-6 cm, tepi rata, letak bersilang berhadapan. Pohon ini memiliki bunga tunggal yang keluar dari ketiak daun, berwarna kuning kehijauan serta buah buni dengan panjang 0.5-1 cm.

\section{Beringin karet (Ficus elastic)}

Pohon berumur panjang (perennial) ini memiliki tinggi yang dapat mencapai 20-30 meter. Percabangannya menyebar tak beraturan hingga membentuk pohon yang rindang. Daun tunggal, bertangkai, tersusun berseling, berbentuk 
lonjong, ujung dan pangkal meruncing, dan mengkilat. Pada pohon muda, daunnya memiliki panjang dan lebar kurang lebih $35 \mathrm{~cm}$ dan $15 \mathrm{~cm}$, sedangkan pada pohon yang tua, dimensinya memiliki besar sekitar 10-15 cm dan 5-7 cm. Pohon ini memiliki batang yang silindris, berwarna coklat tua, dengan permukaannya yang halus.

- Bintaro (Cerbera manghas)

Pohon bintaro biasa tumbuh dengan ketinggian 4-6 meter hingga 12 meter pada ketinggian yang paling maksimal, dengan batangnya yang tegak, berbintik-bintik dan hitam. Daunnya tunggal, tersebar dan lonjong, memiliki panjang 15-20 cm dan lebar 3-5 cm, berwarna hijau. Tanaman ini juga memiliki bunga majemuk berbau harum serta buah berwarna hijau ketika muda (setelah tua menjadi kehitaman).

Biola cantik (Ficus lyrata)

Pertumbuhannya dapat mencapai tinggi 12-15 meter. Pohon pelindung ini terlihat elegan dengan daun yang lebar dan kaku, tidak mudah berguguran meskipun daun sudah tua dan menguning. Dimensi daunnya berukuran panjang sekitar $45 \mathrm{~cm}$ dan lebar $30 \mathrm{~cm}$, meski biasanya juga berukuran lebih kecil.

- Bisbul (Diospyros blancoi)

Bisbul tergolong ke dalam pohon sedang dengan tinggi 10-30 meter, meski pada umumnya memiliki tinggi 15 meter atau kurang daripada itu. Pohon ini bercabang kurang lebih mendatar dan bertingkat. Tajuk keseluruhan berbentuk kerucut, lebat dengan daunnya yang rapat sehingga gelap pada bagian dalamnya. Daun-daunnya tersusun berseling, memiliki bentuk lonjong, dengan daun mudanya berwarna hijau sampai merah jambu. Tanaman ini tergolong ke dalam pohon buah yang buahnya dapat dikonsumsi.

Bungur (Lagerstromia speciosa)

Pohon ini merupakan pohon yang biasa popular sebagai tanaman hias pekarangan, sedangkan pohon besarnya dapat mencapai ketinggian 8 meter. Bunganya berwarna merah jambu, dengan biji berbentuk bulat coklat sebesar kelereng. Bungur memiliki fungsi sebagai pohon peneduh jalan atau pekarangan. 
- Buni (Antidesma bunius)

Tinggi tanaman ini dapat mencapai 30 meter. Tajuknya berbentuk oval dan memiliki kanopi yang padat. Daunnya hijau sepanjang tahun, dengan panjang daun $20 \mathrm{~cm}$ dan lebar $7 \mathrm{~cm}$. Pohon buni memiliki buah yang dapat dikonsumsi, berukuran bulat kecil dengan warna yang beragam.

- Cermai (Phyllanthus acidus)

Tanaman ini tergolong ke dalam pohon kecil dengan tinggi hingga 9 meter, bercabang rendah dan renggang. Daunnya berbentuk bundar telur dengan ujung runcing, tersusun pada ranting seperti daun majemuk menyirip. Bunga berwarna merah dan buah berbentuk bulat, kuning keputihan menyerupai lilin, masam dan berair banyak.

Dadap merah (Erythrina crista-galli)

Tanaman ini tergolong ke dalam pohon rendah, dengan tinggi normal sekitar 5-8 meter. Batangnya memiliki keliling sekitar $50 \mathrm{~cm}$. Dadap merah biasa berbunga pada bulan November hingga Februari. Tajuk pohonnya berbentuk dome.

Delima (Punica granatum)

Delima merupakan tanaman buah yang mampu tumbuh hingga ketingian 5-8 meter. Pohon perdunya memiliki tinggi 2-5 meter. Memiliki percabangan banyak, lemah, berduri pada ketiak daun. Daun berwarna hijau dan bertangkai pendek, letaknya berkelompok. Memiliki bunga berwarna merah, putih, atau ungu. Buah bulat berdiameter 5-12 cm.

- Duku condet (Lansium domesticum)

Duku condet tergolong ke dalam pohon berukuran sedang dengan tinggi hingga 30 meter. Batang beralur dengan banir pipih menonjol di atas tanah. Daun majemuk menyirip ganjil, gundul atau berbulu halus. Bunga berukuran kecil berwarna putih hingga kuning pucat. Termasuk tanaman dengan buah yang dapat dikonsumsi, dengan bentuk jorong dan bulu halus kekuningkuningan.

\section{Durian montong (Durio zibethinus)}

Durian montong merupakan salah satu dari varietas unggul tanaman buah durian. Rata-rata pohon durian memiliki tinggi pohon antara 25-50 meter , 
tergantung pada spesies, pohon tahunan yang hijau abadi. Kulit batang coklat kemerahan dan mengelupas. Tajuknya rindang dan renggang.

- Flamboyan (Delonix regia)

Tinggi pohon flamboyant dapat mencapai 20 meter, dengan tajuk berbentuk lebar. Bunga merah menyala yang hampir memenuhi tajuk. Tanaman ini dapat berfungsi sebagai point of interest, tanaman pengarah jalan jika ditanam masal, dan tanaman peneduh karena tajuknya yang lebar dan besar. Setiap daunnya memiliki panjang 30-50 cm dan juga terdapat 20 hingga 40 pasang pucuk daun primer.

\section{Gamal (Gliricidia sp.)}

Tergolong pohon rendah dengan tinggi antara 2-15 meter dan besar batang 15$30 \mathrm{~cm}$. Daun majemuk, ketika muda berbulu halus seperti beledu. Karangan bunga berupa malai, berwarna putih ungu yang muncul pada akhir musim kemarau. Memiliki buah polong pipih memanjang, berwarna hijau kuning hingga akhirnya berwarna coklat hitam.

Glodogan bulat (Polyalthia fragrans)

Pohon ini memiliki tajuk yang bulat dengan daun yang berwarna hijau mengkilap, ujung menyempit dan tepinya berombak. Panjang daunnya 15-20 cm. Bunga majemuk muncul dari ketiak daun. Buahnya berbentuk bulat dengan diameter $2 \mathrm{~cm}$, berwarna kuning kehijauan. Glodogan bulat juga berfungsi sebagai tanaman pembatas jalan dan pengarah jalan.

- Glodogan tiang (Polyalthia longifolia)

Tanaman yang mencapai tinggi 10-15 meter ini memiliki daun berwarna hijau mengkilap, berbentuk lanset memanjang, bagian ujung menyempit dan tepi daun berombak. Memiliki bunga berukuran kecil dengan warna kuning kehijauan dari ketiak daun. Selain itu terdapat pula buah yang berbentuk seperti melinjo . Tanaman ini juga berfungsi sebagai tanaman pengarah jalan dan penghalang sinar matahari yang efektif jika ditanam sejajar.

Jamblang (Syzygium cumini)

Pohon jamblang memiliki tinggi hingga 20 meter, kokoh, dan beberapa berbatang bengkok.Daun berwarna hijau tua di bagian atas dan merah jambu saat masih muda. Bunga berukuran kecil dan berbau harum, berwarna kuning 
sampai keunguan. Buah buni lonjong berwarna merah tua sampai ungu kehitaman, kulit tipis licin mengkilap.

- Jambu air (Syzigium aqueum)

Tinggi pohon ini sebesar 3-10 meter. Batang berbengkok dan bercabang mulai dari pangkal pohon. Daun tidak atau sedikit berbau aromatis. Bunga berwarna kuning keputihan. Buah buni berbentuk gasing, berwarna putih sampai merah. Jambu air semarang (cincolo) (Syzygium samarangense)

Pohon memiliki tinggi antara 5 hingga 15 meter. Batang berbengkok dan bercabang rendah, berbau aromatis apabila diremas. Bunga berwarna kuning keputihan dan buah buni berbentuk seperti lonceng, buah pir yang melebar dengan lekuk atau alur-alur dangkal membujur di sisinya. Kulit luar buah mengkilap seperti lilin, merah, kehijauan, atau merah-hijau kecoklatan.

Jambu batu (Psidium guajava)

Pohonnya dapat mencapai tinggi 3 hingga 10 meter dengan cabang berjumlah banyak. Permukaan kulit batang licin, keras, dan terkelupas. Warna daun hijau, sedangkan bunga berwarna putih. Tergolong tanaman berbuah yang dapat dikonsumsi.

Jambu bol (Syzygium malasccense)

Tinggi pohon mencapai sekitar 15 meter. Batangnya lurus, bercabang rendah dan bertajuk rimbun padat sampai membulat, memberikan naungan yang berat. Daun tebal agak kaku, bunga berwarna merah atau ungu jambon, buah buni berbentuk bulat sampai lonjong.

- Jambu kancing (air) (Syzygium aqueum)

Tanaman ini tergolong ke dalam varietas jambu air yang kultivarnya kecil. Pada umumnya berupa perdu dengan tinggi antara 3-10 meter. Bercabang mulai dari pangkal pohon dengan batang berkelok. Bunga berwarna kuning keputihan

Jambu putih (air) (Syzygium aqueum)

Tanaman ini merupakan salah satu varietas dari pohon jambu air yang menghasilkan buah jambu dengan kulit luar buah berwarna putih.

Jarak pagar (Jatropha curcas) 
Pohon ini memiliki batang berkayu bulat dan mengandung banyak getah. Tingginya dapat mencapai 5 meter. Daunnya tunggal, lebar, menjari dengan sisi berlekuk-lekuk sebanyak 3-5 buah serta memiliki bunga berwarna kuning kehijauan. Buah dari pohon jarak berbentuk buah kendaga, oval atau bulat telur, permukaan tidak berbulu dan berwarna hijau ketika muda, kuning kecoklatan setelah tua.

Pohon ini dapat tumbuh mencapai 30-40 meter. Batang bebas cabang dapat mencapai 18-20 meter. Memiliki daun yang besar, berbentuk bulat telur terbalik, berhadapan, dengan tangkai yang sangat pendek, serta gugur pada saat musim kemarau. Pohonnya besar dan berbatang lurus. Ranting muda berpenampang segi empat dan berbonggol pada buku-bukunya. Bunga majemuk terletak dalam malai besar, sedangkan buah berbentuk bulat agak gepeng, berambut kasar dengan inti tebal.

Jeruk bali (Citrus maxima)

Jeruk bali memiliki tinggi pohon antara 5 hingga 15 meter. Cabangnya banyak, terletak saling berjauhan dan merunduk pada bagian ujungnya. Daun tanaman berbentuk bulat telur dan berukuran besar. Buah berukuran besar dan berkulit tebal, berbentuk bulat atau bola yang tampak tertekan.

- Kapuk randu (Ceiba pentandra)

Kapuk randu dapat tumbuh hingga 60-70 meter, tergolong ke dalam pohon tinggi. Batang pohonnya cukup besar, mampu mencapai 3 meter. Daunnya majemuk menjari beranak daun tujuh. Sifat bangun daunnya berbentuk memanjang. Pada saat musim kemarau, tanaman ini menggugurkan daunnya seiring dengan pertumbuhan bunga. Kayunya ringan, sehingga tidak baik untuk bahan bangunan.

Kawista batu (Feronia lucida)

Pohon ini tergolong ke dalam suku jeruk-jerukan yang buahnya dapat dimanfaatkan. Tinggi pohon hingga 12 meter dengan cabang dan ranting yang ramping serta batang relative kecil. Daunnya majemuk berukuran panjang hingga $12 \mathrm{~cm}$, anak daun berhadapan, dua sampai tiga pasang. Bunganya 
bergerombol berwarna putih atau hijau dan kemerahan. Buah berbentuk bulat, berkulit keras dan bersisik, serta berwarna coklat putih.

- Kelapa (Cocos nucifera)

Kelapa memiliki tajuk pohon yang berbentuk bulat. Secara alami tanaman ini tumbuh di pantai dengan tinggi mencapai 30 meter. Daunnya hijau bertekstur kasar. Memiliki bunga berwarna putih yang tidak beraroma. Buahnya besar dengan diameter 10 sampai $20 \mathrm{~cm}$ atau bahkan lebih. Fungsi tanaman ini di antaranya untuk menciptakan suasana taman bergaya bali dan sebagai tanaman pengarah jalan pada area rekreasi atau resort.

\section{Kenanga (Cananga odorata)}

Pohon kenanga dapat tumbuh cepat hingga lebih dari 5 meter dan mencapai 12 meter. Batangnya lurus dan berkayu keras. Memiliki daun yang panjang, halus, dan berkilau. Bunganya berwarna hijau kekuningan. Terdapat kenanga berukuran perdu yang biasa tumbuh di halaman rumah dengan tinggi hingga 3 meter.

Kerai payung (Filicium decipiens)

Ketinggian pohon ini dapat mencapai 25 meter. Tajuknya bulat atau semiglobular, dengan daun yang rimbun berwarna hijau tua mengkilap. Daun majemuk menyirip dan bunganya majemuk malai yang muncul dari ketiak daun. Memiliki buah batu berbentuk bulat memanjang. Kerai payung memiliki fungsi sebagai tanaman peneduh dan pengarah jalan.

- Kersen (Muntingia calabura)

Kersen tergolong ke dalam pohon rendah, dengan ketinggian hingga 12 meter. Secara umum memiliki tinggi 3-6 meter saja. Tajuk selalu hijau dan terus menerus berbunga dan berbuah sepanjang tahun. Cabangnya mendatar, menggantung pada bagian ujung sehingga membentuk naungan yang indah. Daun terletak mendatar, berseling, helaian daun tidak simetris, bundar telur lanset, tepi bergerigi dan berujung runcing.

\section{Ketapang (Terminalia catappa)}

Tinggi pohon ini dapat mencapai 35 meter dengan bentuk tajuk yang bertingkat. Daunnya tunggal dan duduk daunnya tersebar. Daun berbentuk bulat telur, liat seperti kulit, berwarna hijau. Daun berubah warna menjadi 
jingga ketika akan rontok. Fungsi tanaman ini sebagai point of interest, tanaman peneduh (khususnya di area parkir), dan tanaman pengarah jalan.

- Kupu-kupu (Bauhinia purpurea)

Tinggi pohon ini 2-6 meter, tergolong ke dalam pohon rendah. Daunnya berbentuk seperti rentangan sayap kupu-kupu. Buah polong berbentuk pipih, ujung lurus dan berparuh. Tanaman ini berfungsi sebagai point of interest, tanaman pengarah jalan, dan tanaman peneduh.

Lamtoro (Leucaena leucocephala)

Pohon lamtoro dapat mencapai tinggi hingga 10-20 meter. Percabangannya rendah, banyak, dengan pepagan kecoklatan atau keabu-abuan, berbintil dan berlentisel. Ranting-ranting bulat torak, dengan ujung berambut rapat. Daunnya majemuk menyirip rangkap. Bunga majemuk berupa bongkol bertangkai panjang yang berkumpul dalam malai berisi 2-6 bongkol. Buah polong berbentuk pita lurus, pipih dan tipis.

Lengkeng (Dimocarpus longan)

Pohonnya dapat mencapai tinggi 40 meter dan berdiameter batang 1 meter. Tergolong ke dalam tanaman berbuah yang dapat dikonsumsi. Memiliki buah bulat, coklat kekuningan.

- Mahoni (Swietenia macrophylla)

Mahoni dapat mencapai tinggi hingga 30 meter. Daun majemuk, menyirip genap berwarna hijau tua. Tajuk berbentuk kolumnar. Memiliki buah bertangkai, berbentuk bola dengan warna cokelat. Tanaman ini dapat berfungsi sebagai tanaman peneduh dan pengarah jalan.

- Mangga (Mangifera indica)

Pohon ini dapat mencapai ketinggian 40 meter, dengan rata-rata tumbuh 10 meter yang banyak dipelihara. Tajuknya besar, dengan batang yang tegak, bercabang agak kuat, berdaun lebat membentuk tajuk indah berbentuk kubah, dengan diameter hingga 10 meter. Daunnya tunggal, dengan letak tersebar tanpa daun pemumpu. Tergolong ke dalam tanaman buah yang dapat dikonsumsi.

Mangga (apel) (Mangifera indica) 
Tanaman ini merupakan salah satu varietas unggul dari spesies Mangifera indica (mangga). Ciri yang membedakannya dengan mangga yang biasa terlihat antara lain kulit buah yang berwarna kemerah-merahan dengan bentuk buah bulat menyerupai apel. Tinggi pohon ini juga diupayakan untuk tidak melebihi 2 meter.

- Mangga (arum manis) (Mangifera indica)

Termasuk ke dalam salah satu varietas unggul asal Probolinggo, Jawa Timur yang tumbuh baik pada dataran rendah. Buah berbentuk jorong, berparuh sedikit dan ujungnya meruncing. Mangga (okyong) (Mangifera indica)

Mangga ini juga termasuk ke dalam varietas unggul yang berasal dari Thailand. Buahnya berwarna kulit hijau tua seperti mangga arum manis namun dengan ukuran yang lebih besar. Pohonnya dapat menghasilkan lebih banyak buah dengan satu dompol dapat berisi 7 buah mangga.

\section{Matoa (Pometia pinnata)}

Pohon matoa memiliki tajuk yang bulat, memiliki gradasi daun yang menarik. Pohon in tergolong ke dalam pohon tinggi dengan rata-rata ketinggian 18 meter dan diameter rata-rata maksimum $100 \mathrm{~cm}$. Daun berbentuk lonjong bulat, tumbuh teratur di sepanjang tangkai tanaman. Tanaman ini memiliki fungsi sebagai tanaman peneduh pad ataman berskala luas.

- Melinjo (Gnetum gnemon)

Pohon melinjo memiliki ketinggian hingga 11 meter, berbentuk tajuk tiang kerucut dari pangkal menyempit ke ujung. Tekstur pohon sedang, daun berwarna hijau tua, berbentuk batang bulat, sistem percabangan monopodial dengan arah tumbuh dahan tegak dan tidak memiliki banir.

Mengkudu (Morinda citrifolia)

Tinggi tanaman mengkudu adalah 3-6 meter, tergolong ke dalam tanaman rendah. Daun tunggalnya berwarna hijau. Termasuk ke dalam jenis tanaman buah dengan bentuk buahnya yang terlihat eksotis, berbentuk lonjong tidak teratur, dan berwarna putih kekuningan. Tanaman ini dapat digunakan sebagai focal point di saat berbunga dan berbuah serta sebagai tanaman peneduh.

Mimba (Azadirachta indica) 
Pohon mimba memiliki tinggi 8-15 meter. Batangnya simpodial, helai anak daun berbentuk memanjang lanset bengkok, pangkal runcing tidak simetri, tepi daun bergerigi kasar, dan warna hijau muda.

- Nangka (Artocarpus heterophyllus)

Pohon nangka secara umum berukuran sedang, dengan tinggi hingga 20 meter. Batang bulat silindris, berdiameter hingga 1 meter. Tajuk padat dan lebat, melebar dan membulat jika berada di tempat terbuka. Daun tunggal, tersebar, agak tebal seperti kulit, kaku, bertepi rata. Buah majemuk berbentuk gelondong memanjang, seringkali tidak merata dengan panjang hingga 100 $\mathrm{cm}$.

Palem ekor tupai (Wodyetia bifurcata)

Tinggi tanaman ini mencapai 6 meter, ditanam di tanah berpasir dan tidak tergenang air. Daun hijau tua menjuntai menyerupai ekor, kumpulan daunnya seperti ekor tupai.

Palem hijau (Actinophloeus macarthurii)

Palem hijau memiliki warna dominan hijau. Ketinggiannya dapat mencapai 6 meter. Warna buah merah merekah dan dapat tumbuh bergerombol. Tanaman ini termasuk ke dalam pohon rendah.

- Palem phoenix (Phoenix roebelenii)

Palem ini tergolong ke dalam palem sedang, tumbuh dengan tinggi antara 2 hingga 3 meter. Daunnya memiliki panjang 60-120 cm. Bunganya kecil, berwarna kekuningan. Buahnya menyerupai kurma berukuran kecil dengan daging buah yang tipis.

- Palem putri (Veitchia merilii)

Palem putri tergolong tanaman hias yang dapat tumbuh di mana saja. Memiliki tajuk yang menjurai, dengan bentuk keseluruhan tidak terlalu besar. Daun berwarna hijau dan bertekstur sedang. Tanaman ini memiliki bunga yang berwarna kuning dan tidak beraroma.

Palem raja (Roystonea regia)

Tanaman ini memiliki tinggi antara 25-30 meter dengan batangnya yang kokoh, tergolong ke dalam pohon tinggi. Daunnya berwarna hijau segar 
berbentuk menyirip. Fungsinya antara lain sebagai tanaman pengarah jalan dan pencipta suasana taman bergaya formal.

- Pinang (Areca catechu)

Tumbuhan ini memiliki batang yang lurus langsing, dengan tinggi mencapai 25 meter dan diameter lingkar batang $15 \mathrm{~cm}$. Pelepah daunnya berbentuk tabung dengan panjang $80 \mathrm{~cm}$, bertangkai daun pendek, dan helaian daun hingga $80 \mathrm{~cm}$. Memiliki bunga betina berwarna hijau dan bunga jantan berwarna putih kuning. Buah buni berwarna merah jingga berbentuk bulat telur terbalik dan memanjang.

Pohon roda (Hura crepitans)

Pohon ini memilikii perawakan yang besar dengan lebar tajuk kurang lebih 10 meter, berbatang lurus, berduri rapat, dan memiliki tinggi hingga 20 meter. Daunnya tunggal berbentuk jantung dan bergerigi pada tepiannya, serta memiliki buah berbentuk bulat seperti roda, memiliki alur di bagian luarnya. Pada area pinggir jalan, pohon ini dapat berfungsi sebagai peneduh dan tanaman hias.

\section{Rainbow eucalyptus (Eucalyptus deglupta)}

Pohon ini mampu mencapai ketinggian hingga 60 meter, berbatang lurus dan berbanir. Tajuk berdaun jarang, pada waktu muda agak rapat. Daunnya tunggal berhadapan, berbentuk jorong sampai melanset. Perbungaan menyerupai payung di ujung ranting. Buah berupa kotak.

- Rambutan (Nephelium lappaceum)

Pohon rambutan memiliki ketinggian hingga 8 meter dengan lebar tajuk berdiameter 8 meter. Daunnya majemuk menyirip, berbentuk bulat telur. Berbunga mejemuk yang juga menjadi sumber utama nektar bagi lebah peliharaan. Tergolong ke dalam pohon penghasil buah yang dapat dikonsumsi. Rambutan (aceh) (Nephelium lappaceum)

Pohonnya tinggi dan memiliki buah yang lebat dengan rata-rata hasil 160-170 ikat per pohon. Kulit buah berwarna merah kuning dan halus. Salah satu varietas unggul dari rambutan.

Rambutan (cimacan) (Nephelium lappaceum) 
Memiliki buah yang kurang lebat dengan rata-rata hasil 90-170 ikat per pohon. Kulit buah berwarna merah kekuningan hingga merah tua, berambut kasar dan agak jarang.

- Rambutan (rapiah) (Nephelium lappaceum)

Tergolong dalam varietas unggul dari rambutan. Buahnya tidak terlalu lebat namun memiliki mutu buah yang tinggi. Kulit buah berwarna hijau-kuningmerah tidak merata dengan berambut agak jarang.

Rukam (Flacourtia rukam)

Rukam memiliki tinggi pohon yang mencapai 20 meter serta berbatang dan bercabang lekuk, beralur. Batangnya memiliki duri-duri berukuran panjang hingga $10 \mathrm{~cm}$. Daunnya bundar telur lonjong berwarna hijau tua mengkilat saat tanaman tua dan berwarna merah kecoklatan saat masih muda. Bunga berwarna kuning kehijauan dan berkelamin tunggal pada umumnya. Buah berbentuk bulat gepeng sampai bulat telur sungsang.

\section{Saga (Adenanthera pavonina)}

Pohon saga memiliki tinggi yang mencapai 15-30 meter dengan daun berwarna hijau, menyirip ganda seperti tanaman suku polong-polongan lain. Tanaman ini tergolong ke dalam pohon tinggi. Memiliki biji berwarna merah cerah dan berbentuk bola pipih. Tanaman ini memiliki fungsi sebagai tanaman peneduh karena lebar tajuknya yang cukup besar dan tinggi.

- Salam (Syzygium polyanthum)

Pohon salam memiliki tinggi mencapai 30 meter, dengan kulit batangnya berwarna coklat abu-abu, memecah, atau bersisik. Daunnya tunggal, terletak berhadapan, tangkainya hingga $12 \mathrm{~mm}$. Bentuk daunnya jorong-lonjong, jorong sempit atau lanset, 5-16 x 2.5-7 cm. Karangan bunga berupa malai dengan banyak kuntum bunga, 2-8 cm, muncul di bawah daun atau kadangkadang pada ketiak.

Sawo duren (Crateva religiosa)

Tanaman ini tumbuh tinggi hingga mencapai 30, selalu hijau dan tumbuh cepat. Batangnya silindris, tegak, permukaan kasar berwarna coklat, abu-abu gelap hingga keputihan. Daun tunggal berwarna coklat keemasan pada bagian permukaan bawah daun, sedangkan permukaan atasnya berwarna hijau cerah. 
Buah buninya bulat berdiameter 5-10 cm dengan kulit buah licin mengkilap, coklat keunguan, atau hijau kekuningan sampai keputihan.

- Sawo kulon (manila) (Manilkara zapota)

Sawo jenis ini termasuk ke dalam varietas unggul dari sawo manila. Ketinggiannya dapat mencapai 20 meter dengan sistem percabangan cukup rapat dan batang berkayu keras. Daunnya berbentuk bulat memanjang, berwarna hijau mengkilap di bagian atas dan hijau muda tua kecoklatan di bagian bawah. Untuk sawo kulon itu sendiri, buahnya lonjong berbiji banyak, bergetah dan relatif tahan lama apabila disimpan.

Sawo manila (betawi) (Manilkara zapota)

Jenis sawo ini termasuk ke dalam jenis sawo manila. Buah berbentuk lonjong, daging buahnya tebal, banyak mengandung air dan rasanya manis. Rata-rata pohon yang besar memiliki tinggi 30-40 meter dan bercabang rendah,

Sempur (Dillenia sp.)

Pohon sempur memiliki tinggi antara 40-50 meter. Batangnya memiliki permukaan yang halus, sedikit retak, dengan warna coklat kemerahan. Daunnya tunggal, bertepi rata, bergelombang atau bergigi, bertulang daun menonjol, dan tangkai daun sering bersayap. Pohon ini tergolong ke dalam pohon buah yang dapat dikonsumsi.

- Sengon (Paraserianthes falcataria)

Pohon ini dapat mencapai ketinggian sekitar 30-45 meter dengan diameter batang 70-80 cm. Tajuknya berbentuk seperti payung dengan daun yang tidak begitu rimbun dan lebat. Warna daun hijau pupus, bunganya berwarna putih kekuning-kuningan, dan memiliki buah berbentuk polong, pipih dengan panjang 6-12 cm.

Srikaya (Annona squamosa)

Pohon srikaya tergolong ke dalam perdu hingga pohon yang dapat mencapai ketinggian 8 meter. Daunnya berselang, sederhana, membujur dengan panjang 7-12 cm dan lebar 3-4 cm. Memiliki bunga berwarna kuning-hijau berbintik ungu di dasarnya. Batangnya gilik, percabangan simpodial, ujung rebah, kulit batang coklat muda. Pohon ini tergolong ke dalam pohon buah yang dapat dikonsumsi. 
- Sukun (Artocarpus altilis)

Pohon sukun tergolong ke dalam pohon tinggi dengan ketinggiannya yang mencapai 24-30 meter serta diameter pohon mencapai 1.8 meter. Daun berwarna hijau gelap dengan permukaannya yang mengkilap. Pohon ini memiliki buah berbentuk oval berdiameter $15 \mathrm{~cm}$ dan berat 1-4.5 kg. Bunganya kecil, dengan bunga jantan berwarna kuning kecoklatan dan bunga betina berwarna kehijauan. Tanaman sukun memiliki fungsi sebagai tanaman peneduh karena lebar tajuknya yang cukup besar dengan ukuran pohonnya yang cukup tinggi.

\section{Tanjung (Mimusoph elengi)}

Pohon tanjung memiliki tajuk yang bulat dan indah, memiliki perpaduan warna daun yang hijau mengkilap. Tanaman ini tergolong ke dalam pohon sedang dengan tinggi mencapai 15 meter. Buahnya yang matang akan menghasilkan warna merah jingga. Fungsinya antara lain sebagai peneduh, pengarah jalan, dan tabir jika ditanam masal sejajar. 